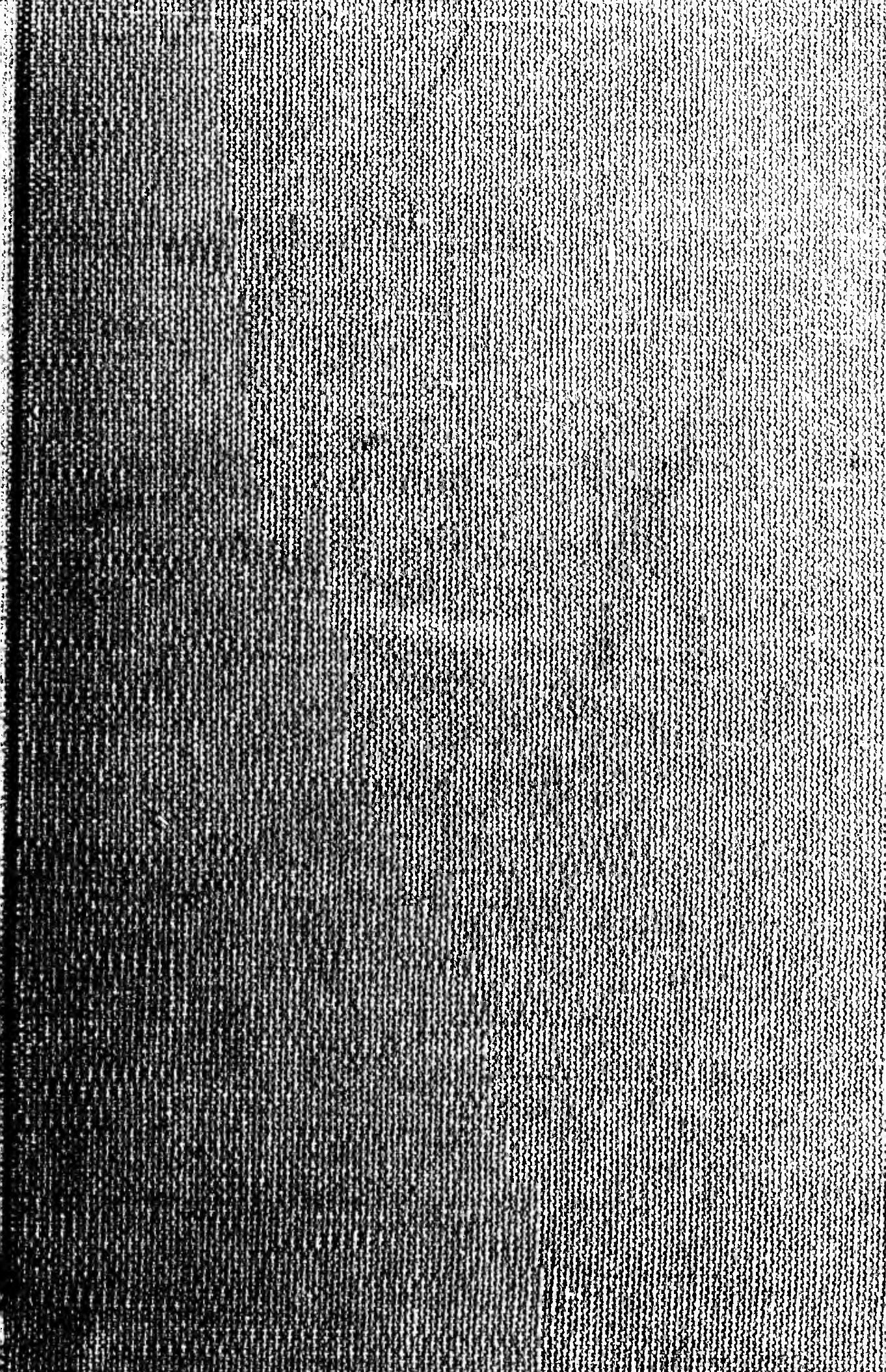





$r$ 

The Planters of Colonial Virginia 



\title{
The PLANTERS OF COLONIAL VIRGINIA
}

\author{
By THOMAS J. WERTENBAKER
}

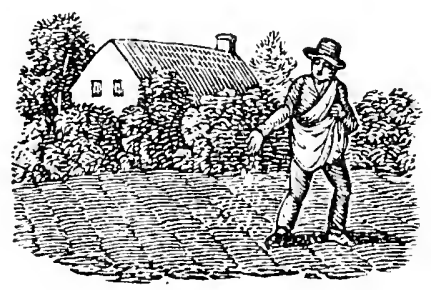

\section{PRINCETON}

PRINCETON UNIVERSITY PRESS LONDON: HUMPHREY MILFORD OXFORD UNIVERSITY PRESS 
Copyrighted and Published 1922. by Princoton L'niaersity Press

PRINTED AT THE PRINCETON UNIVERSITY PkESS, PRINCETON, U. S. A.

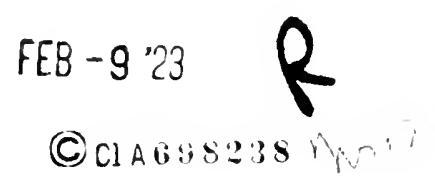




\section{CONTENTS}

\begin{tabular}{|c|c|c|}
\hline CHAPTER & I: & ENGLAND IN THE NEW WORLD \\
\hline CHAPTER & II : & THE INDIAN WEED \\
\hline CHAPTER & III : & THE VIRGINIA YEOMANRY \\
\hline CHAPTER & IV : & FREEMEN AND FREEDMEN \\
\hline CHAPTER & $v:$ & TIIE RESTORATION PERIOD \\
\hline CHAPTER & VI : & THE YEOMAN IN VIRGINIA HISTORY \\
\hline CHAPTER & VII : & WORLD TRADE \\
\hline CHAPTER & VIII : & BENEATII THE BLACK TIDE \\
\hline \multicolumn{3}{|c|}{ NOTES TO CHAPTERS } \\
\hline \multicolumn{3}{|l|}{ APPENDIX } \\
\hline INDEX & & \\
\hline
\end{tabular}





\title{
CHAPTER I
}

\author{
England in THE NeW World
}

At the beginning of the Seventeenth century colonial expansion had become for England an economic necessity. Because of the depletion of her forests, which constituted perhaps the most important of her natural resources, she could no longer look for prosperity from the old industries that for centuries had been her mainstay. In the days when the Norman conquerors first set foot upon English soil the virgin woods, broken occasionally by fields and villages, had stretched in dense formation from the Scottish border to Sussex and Devonshire. But with the passage of five centuries a great change had been wrought. The growing population, the expansion of agriculture, the increasing use of wood for fuel, for shipbuilding, and for the construction of houses, had by the end of the Tudor period so denuded the forests that they no longer sufficed for the most pressing needs of the country.

Even at the present day it is universally recognized that a certain proportion of wooded land is essential to the prosperity and productivity of any country. And whenever this is lacking, not only do the building, furniture, paper and other industries suffer, but the rainfall proves insufficient, spring floods are frequent and the fertility of the soil is impaired by washing. These misfortunes are slight, however, compared with the disastrous results of the gradual thinning out of the forests of Elizabethan England. The woods were necessary 
tor three all-important industries, the industries upon which the prosperity and wealth of the nation were largely dependent -shipbuilding, for which were needed timber, masts, pitch, tar, resin; the manufacture of woolens, calling for a large supply of potash; smelting of all kinds, since three hundred years ago wood and not coal was the fuel used in the furnaces. It was with the deepest apprehension, then, that thoughtful Englishmen watched the gradual reduction of the forest areas, for it seemed to betoken for their country a period of declining prosperity and economic decay. "When therefore our mils of Iron and excesse of building have already turned our greatest woods into pasture and champion within these few years," says a writer of this period, "neither the scattered forests of England, nor the diminished groves of Ireland will supply the defect of our navy."1

From this intolerable situation England sought relief through foreign commerce. If she could no longer smelt her own iron, if she could not produce ship-stores or burn her own wood ashes, these things might be procured from countries where the forests were still extensive, countries such as those bordering the Baltic-Germany, Poland, Russia, Sweden. And so the vessels of the Muscovy Company in the second half of the Sixteenth century passed through the Cattegat in large numbers to make their appearance at Reval and Libau and Danzig, seeking there the raw materials so vitally necessary to England. "Muscovia and Polina doe yeerly receive many thousands for Pitch, Tarre, Sope Ashes, Rosen, Flax, Cordage, Sturgeon, Masts, Yards, IVainscot, Firres, Glasse, and such like," wrote Captain John Smith, "also Swethland for Iron and Copper.",

But this solution of her problem was obviously unsatisfactory to England. The northern voyage was long, dangerous and costly; the King of Denmark, who controlled the entrance 
to the Baltic, had it within his power at any moment to exclude the English traders; the Muscovy company no longer enjoyed exemption from customs in Prussia, Denmark and Russia. In case war should break out among the northern nations this trade might for a time be cut off entirely, resulting in strangulation for England's basic industries. "The merchant knoweth," said the author of A True Declaration, "that through the troubles in Poland \& Muscovy, (whose eternall warres are like the Antipathy of the Dragon \& Elephant) all their traffique for Masts, Deales, Pitch, Tarre, Flax, Hempe, and Cordage, are every day more and more indangered." Moreover, the trade was much impeded by the ice which for several months each year choked some of the northern ports.

The most alarming aspect of this unfortunate situation was the effect of the shortage of shipbuilding material upon the merchant marine. Situated as it was upon an island, England enjoyed communication with the nations of the world only by means of the ocean pathways. Whatever goods came to her doors, whatever goods of her own manufacture she sent to foreign markets, could be transported only by sea. It was a matter of vital import to her, then, to build up and maintain a fleet of merchant vessels second to none. But this was cbviously difficult if not impossible when "the furniture of shipping" such as "Masts, Cordage, Pitch, Tar, Rossen" were not produced in quantity by England itself, and could be had "only by the favor of forraigne potency." A Already, it was stated, the decay of shipping was manifest, while large numbers of able mariners were forced to seek employment in other countries. "You know how many men for want of imploiment, betake themselves to Tunis, Spaine and Florence," declared one observer, "and to serve in courses not warrantable, which would better beseeme our own walles and borders to bee spread with such branches, that their native countrey and 
not forreine Princes might reape their fruit, as being both exquisite Navigators, and resolute men for service, as any the world affords."

It must be remembered that the merchant vessel three hundred years ago constituted an important part of the nation's sea defence. The fleet which met the mighty Spanish Armada in the Channel and inflicted upon it so decisive a defeat, was made up in large part of volunteer ships from every English port. And the Britisher knew full well that the merchant marine constituted the "wooden walls" of his country, knew that its decay would leave England almost defenseless. At the moment when one able writer was pointing out that "the Realme of England is an Island impossible to be otherwise fortified than by stronge shippes," another was complaining that there were scarce two vessels of Ioo tons belonging to the whole city of Bristol, and few or none along the Severn trom Gloucester to Land's End on one side, and to Milford Haven on the other. ${ }^{6}$

For this intolerable situation there could be but one remedy - England must secure colonial possessions to supply her with the produsts for which her forests were no longer sufficient. Her bold navigators had already crossed the Atlantic, returning with alluring stories of the limitless resources of the New World, of mighty forests spreading in unbroken array for hundreds of miles along the coast and back into the interior as far as the eye could see. ${ }^{7}$ Why, it was asked, should Englishmen be forced to make the hazardous journey to the Baltic in order to procure from other nations what they might easily have for themselves by taking possession of some of the limitless unoccupied areas of America? It was folly to remain in economic bondage while the road to independence stretched so invitingly before them.

Long before the Goodspeed, the Discovery and the Sarah 
Constant turned their prows into the waters of the James, able English writers were urging upon the nation the absolute necessity for colonial expansion. In I 584 the farseeing Hakluyt pointed out that the recent voyage of Sir Humphrey Gilbert had proved that "pitche, tarr, rosen, sope ashes" could be produced in America in great plenty, "yea, as it is thought, ynoughe to serve the whole realme." Carleill had the previous year made an effort to persuade the Muscovy Company to divert its energies toward America. Why remain under the power of the King of Denmark, he asked, or other princes who "command our shippes at their pleasure," when all the products of the Baltic regions were to be had from unoccupied territories which so easily could be placed under the English flag?

It has often been taken for granted that the statesmen and merchants of three centuries ago pursued always a mistaken and shortsighted economic policy. John Fiske assures us that even at the close of the Eighteenth century the barbarous superstitions of the Middle Ages concerning trade between nations still flourished with scarcely diminished vitality. Yet it requires but a cursory study of the theories and arguments of the Elizabethan economists to realize that they were men of ability and vision, that they knew what was needed and how to procure it, that they were nearer right than many have supposed. In fact, they acted upon sound economic principles a century and a half before Adam Smith formulated and expounded them.

These men realized keenly that England's safety demanded a larger measure of economic independence and they pointed out what seemed to be the only available means of securing it. Since her forests upon which her prosperity in the past had been so largely based, were nearing the point of exhaustion, she must expand to embrace new lands where the virgin 
growth of trees stood untouched. If this is barbarous, then the recent efforts of Italy to gain an independent coal supply, of Great Britain to get control of various oil fields, of the United States to build up a dye industry, are all likewise barbarous. In fact the world today in matters of economic policy has by no means gotten away from the conceptions of the men whose able writings cleared the way for the beginning of the British colonial empire.

But it must not be supposed that England in this matter was concerned only for her supply of naval stores, potash and pig iron. There were other products, not so vital it is true, but still important, which she was forced to seek abroad. From the south of Europe came salt, sugar, wine, silk, fruits; from the Far East saltpetre and dyes, together with spices for making palatable the winter's stock of food; from Holland came fish, from France wine and silk. And as in the Baltic, so elsewhere the merchants of London and Bristol and Plymouth found their activities resented and their efforts blocked and thwarted.

All commerce with the dominions of the King of Spain was carried on with the greatest difficulty. "Our necessitie of oiles and colours for our clothinge trade being so greate," pointed out Hakluyt, "he may arreste almoste the one halfe of our navye, our traficque and recourse beinge so greate in his dominions." The rich trade with the Far East was seriously hampered by the Turks, through whose territories it had to pass, and often a heavy tribute was laid upon it by the Sultan and his minions. Even after the merchants had succeeded in lading their vessels in the eastern Mediterranean with goods from the Orient, they still had to run the gauntlet of the hostile Powers who infested that sea. If they escaped the Knights of Malta, they might be captured by the corsairs of Algeria or Tripoli. 
The trade with France had also declined greatly during the closing years of the Sixteenth century. Not only had the religious wars proved a tremendous obstacle, but the government at Paris discriminated against the woolens from England by means of custom duties, while the French workmen were themselves manufacturing cloth of excellent quality in larger amounts than had hitherto been thought possible. In the Low Countries the long and bitter struggle of the people against the bloody bands of Alva had wrought such destruction and had so ruined industry that all foreign commerce had greatly declined. ${ }^{9}$

There can be no surprise, then, that many English economists felt that a crisis had been reached, that nothing save the immediate establishment of colonies would prevent disaster. With the woolen industry declining, with the shipbuilding centres almost idle, with able mariners deserting the service, with the foreign market gradually closing to English wares, with the country overrun with idle and starving laborers, with some of her chief natural resources nearly exhausted and the trade by which her needs were replenished in constant danger, England turned to America as her hope for salvation. Upon securing a foothold in the New World, hitherto monopolized by Spain and Portugal, depended Albion's future greatness and prosperity.

It is this which gave to the London Company its national character, and made its efforts to establish a colony across the Atlantic a crusade, a movement in which every Englishman was vitally concerned. The great lords and wealthy merchants who comprised the Company knew well enough that there was little hope of immediate returns upon the money they subscribed so liberally. They expected to receive their reward in another way, in the revival of English industrial life and the restoration of English economic independence. It is a singu- 
lar perversion of history, an inaccurate interpretation of men and events, which for so many years beclouded our ronception of the beginning of the British colonial empire. ' he settlement at Jamestown was not the product of a selfish, private venture, but the fruition of long years of thought and endeavor, long years of pleading with the English public, of the conscious and deliberate efforts of the nation to expand to the New WVorld, to break the bonds of economic dependence and to restore to England the place in the world which rightfully was hers.

In addition to, but closely associated with, the economic causes of Anglo-Saxon expansion was the realization in England of the need for prompt action in putting a limit to the growing domains of the King of Spain. In the century which had elapsed since Columbus opened a new world to the peoples of Europe, this monarch had seized the richest part of the great prize, and was still reaching forward to the north and to the south. Unless England took advantage of the present opportunity, the vast American continents might be closed to her forever. Anglo-Saxon civilization in that case might well remain permanently cooped up in the little island that had seen its inception, while the Spanish language and Spanish institutions expanded to embrace the garden spots of the world. ${ }^{10}$

There were still other motives for this great movement. The English felt the prime necessity of discovering and controlling a new route to the East, they wished to expand the influence of the Anglican church and convert the Indians, they hoped to seize and fortify strategic points in America which would aid them in their struggles with the Spaniards. But these things, important as they were, paled beside the pressing necessity of national expansion, of rehabilitating English industrial life, restoring the merchant marine and securing economic independence. 
Thus, when Captain Newport returned in 1607 to report that the colony of Virginia had been safely launched, many Englishmen were aroused to a high pitch of hope and expectation. Now at last a province had been secured which could supply the raw materials which England so greatly needed. The active supporters of the undertaking were lavish in their promises. Virginia would yield better and cheaper timber for shipping than Prussia or Poland, she would furnish potash in abundance, and since wood could there be had for the cutting, her copper and iron ore could be smelted on the spot. Wine could be made there, as excellent as that of the Canaries, they boasted, while it was hoped soon to manufacture silk rivalling in fineness that of Persia or of Turkey. The waters of the colony were full of "Sturgion, Caviare and new land fish of the best," her fields could produce hemp for cordage and flax for linen. As for pitch, tar, turpentine and boards, there was a certainty of a rich return. ${ }^{11}$ In February 1608, the Council of Virginia wrote to the corporation of Plymouth: "The staple and certain Comodities we have are Soap-ashes, pitch, tar, dyes of sundry sorts and rich values, timber for all uses, fishing for sturgeon and divers other sorts . . . making of Glass and Iron, and no improbable hope of richer mines."12

And no sooner had the infant colony been established than the Company turned with enthusiasm to the production of these highly desired commodities. A number of foreigners, Dutchmen and Poles skilled in the manufacture of ship-stores, were sent over to make a start with pitch, tar, turpentine and potash. They were to act as instructors, also, and it was expected that within a few years the Virginia forests would be filled with workers in these trades. Unfortunately their efforts met with ill success, and save for a few small samples of pitch and tar which were sent to England, nothing of value was produced. 
For this failure the reason is apparent. All the able economists and statesmen who had predicted that the colony would become an industrial center had overlooked one vitally important factor-the lack of cheap labor. No matter how rich in natural resources, Virginia could not hope to compete with the long-established industries of Europe and Asia, because she lacked the abundant population requisite to success. It had been imagined by Hakluyt and others that the colony could avail herself of the surplus population of England, could drain off the upper stratum of the idle and unemployed. What more feasible than to set these men to work in the forests of the New IVorld to produce the raw materials the want of which was responsible for unemployment in England itself!

But the voyage across the Atlantic was so long and costly, that it proved impossible to transport in any reasonable length of time enough workers to Virginia to supply her needs. And the few thousand that came over in the early years of the Seventeenth century were in such great demand that they could secure wages several times higher than those in vogue throughout Europe. Thus the London Company, from the very outset, found itself face to face with a difficulty which it could never surmount. Virginia could not compete with the shipstores of the Baltic nations because her labor, when indeed it was found possible to secure labor at all, was far more expensive than that of Poland or Sweden or Russia. It mattered not that the Company sent over indentured servants, bound by their contracts to work for a certain number of years; the effect was the same. The cost of transportation swallowed up the profits from the servant's labor, when that labor was expended upon industries which had to face the competition of the cheap workers of the Old World.

It speaks well for the acumen of Captain John Smith that 
he seems to have been the first to grasp clearly this truth. He wrote that the workingmen had made a beginning of "Pitch and Tarre, Glass, Sope-ashes and Clapboard," but that little had been accomplished. "If you rightly consider what an infinite toyle it is in Russia and Swetland, where the woods are proper for naught else, and though there be the helpe both of man and beast in those ancient Common-wealths, which many a hundred years have used it, yet thousands of those poor people can scarce get necessaries to live . . you must not expect from us any such matter." 13

The attempt to produce iron in Virginia was pursued even more vigorously, but with equally poor success. The early settlers, eager to assure the Company that the venture they had entered upon would soon yield a rich return, spoke enthusiastically of the numerous indications of the presence of iron ore. In I 609 Captain Newport brought with him to England a supply of ore from which sixteen or seventeen tons of metal were extracted of a quality equal or superior to that obtained from any European country. The iron was sold to the East India Company at the rate of $\mathfrak{f}_{4}$ a ton. ${ }^{14}$ Immediately plans were launched for taking advantage of what seemed to be a splendid opportunity. In the course of the first three years machinery for smelting and manufacturing iron was sent over and men were set to work to operate it. But the difficulties proved too great and ere long the attempt had to be abandoned.

The Company had no idea of relinquishing permanently its quest for staple commodities, however, and soon a new and far more ambitious project was set on foot for extracting the ore. The spot selected was at Falling Creek, in the present county of Chesterfield, a few miles below the rapids of the James river. George Sandys had noted with satisfaction some years before that the place was in every respect suited for 
iron smelting, for in close proximity to the ore was wood in abundance, stones for the construction of the furnace and deep water for transportation. To him it seemed that nature itself had selected the site and endowed it with every facility which the enterprise could require. ${ }^{15}$ Here the London Company spent from $\mathfrak{f}_{4}, \mathrm{OOO}$ to $\mathfrak{f}_{5}, 000$ in a supreme effort to make their colony answer in some degree the expectations which had been placed in it. A Captain Blewit, with no less than 80 men, was sent over to construct the works, upon which, they declared, were fixed the eyes of "God, Angels and men." But Blewit soon succumbed to one of the deadly epidemics which yearly swept over the little colony, and a Mr. John Berkeley, accompanied by 20 experienced workers, came over to take his place.

At first things seem to have gone well with this ambitious venture. Soon the Virginia forests were resounding to the whir of the axe and the crash of falling trees, to the exclamations of scores of busy men as they extracted the ore, built their furnace and began the work of smelting. Operations had progressed so far that it was confidently predicted that soon large quantities of pig iron would be leaving the James for England, when an unexpected disaster put an abrupt end to the enterprise. In the terrible massacre of 1622 , when the implacable Opechancanough attempted at one stroke to rid the country of its white invaders, the little industrial settlement at Falling Creek was completely destroyed. The furnace was ruined, the machinery thrown into the river, the workmen butchered. This project, which had absorbed so much of the attention and resources of the Company, is said to have yielded only a shovel, a pair of tongs and one bar of iron. ${ }^{16}$

The history of the attempts to establish glass works in Virginia is also a story of wasted energy and money, of final failure. The Dutch and Polish workers who came in 1608 set up a furnace at Jamestown, ${ }^{17}$ but nothing more is heard 
of them, and it is clear that they met with no success. Nor did Captain William Norton, who arrived in I62 I with a number of skilled Italian glass workers fare any better. ${ }^{18}$ In I623 George Sandys wrote: "Capt. Norton dyed with all save one of his servants, the Italians fell extremely sick yet recovered; but I conceave they would gladly make the work to appear unfeasable, that they might by that means be dismissed for England. The fier hath now been for six weeks in ye furnace and yet nothing effected. They claim that the sand will not run." Shortly after this the workmen brought matters to an end by cracking the furnace with a crowbar. ${ }^{18}$

Thus ended in complete failure the efforts of England to reap what she considered the legitimate fruits of this great enterprise. The day of which her farseeing publicists had dreamed had arrived; she had at last challenged the right of Spain to all North America, her sons were actually settled on the banks of the James, a beginning had been made in the work of building a colonial empire. But the hope which had so fired the mind of Hakluyt, the hope of attaining through Virginia British economic independence, was destined never to be fulfilled. However lavishly nature had endowed the colony with natural resources, however dense her forests, however rich her mines, however wide and deep her waterways, she could not become an industrial community. Fate had decreed for her another destiny. But England was reluctant to accept the inevitable in this matter. Long years after Sir Edwin Sandys and his fellow workers of the London Company had passed to their rest, we find the royal ministers urging upon the colony the necessity of producing pig iron and silk and potash, and promising every possible encouragement in the work. But the causes which operated to bring failure in 1610 or 1620 prevented success in 1660 and 1680. Virginia had not the abundant supply of labor essential to the 
development of an industrial community and for many decades, perhaps for centuries, could not hope to attain it. Her future lay in the discovery and exploitation of one staple commodity for which she was so preeminently adapted that she could, even with her costly labor, meet the competition of other lands. The future history of Virginia was to be built up around the Indian plant tobacco. 


\section{CHAPTER II}

\section{The Indian WeEd}

History is baffling in its complexity. The human mind instinctively strives for simplicity, endeavors to reproduce all things to set rules, to discover the basic principles upon which all action is based. And in various lines of research much success has attended these efforts. We know the laws underlying the movements of the planets, of various chemical reactions, of plant and animal life. It is inevitable, then, that attempts should be made to accomplish similar results in history, to master the vast multitude of facts which crowd its pages, many of them seemingly unrelated, and show that after all they obey certain fundamental laws. Despite the vaunted freedom of the human will, it is maintained, mankind like the planets or the chemical agents, cannot escape the operation of definite forces to which it is subjected. And if these forces are studied and understood, to some extent at least, the course of future events may be predicted.

Thus it may be accepted as practically established that in any country and with any people a condition of continued disorder and anarchy must be succeeded by one of despotism. History records, we believe, no exception to this rule, while there are many instances which tend to confirm it. The absolute rule of the Caesars followed the anarchy of the later Roman republic, the Oliverian Protectorate succeeded the British civil wars, the first French Empire the Reign of Terror, the Bolshevik despotism the collapse of the old regime in Russia. Such will always be the case, we are told, because mankind turns instinctively to any form of government in quest of 
protection from anarchy, and the easiest form of government to establish and operate is despotism.

Not content with generalizations of this kind, however, certain historians have undertaken to reduce all human action to some one great fundamental principle. The Freudian view cmphasizes the influence of sex; Buckle maintains that the effect of climate is all-powerful. In recent years many students, while not agreeing that the solution of the problem is quite so simple, yet believe that underlying all social development will be found economic forces of one kind or another, that in commerce and industry and agriculture lies the key to every event of moment in the history of mankind. Often these forces have been obscured and misunderstood, but close study will always reveal them. It is folly to waste time, they say, as writers have so long done, in setting forth the adventures of this great man or that, in dwelling upon the details of political struggles or recounting the horrors of war. All these are but surface indications of the deeper movements underneath, movements in every case brought about by economic developments.

But this interpretation of history is by no means universally accepted. While admitting readily that the conditions surrounding the production and exchange of useful commodities have affected profoundly the course of events, many historians deny that they give the key to every important movement. We must study also the progress of human thought, of religion, of politics, or our conception of history will be warped and imperfect. How is it possible to explain the French religious wars of the Sixteenth century by the theory of economic causes? In what way does it account for the rebellion of Virginia and North Carolina and Maryland against the British government in 1775 ? How can one deny that the assassination of Abraham Lincoln affected profoundly the course of American history? 
These efforts to simplify the meaning of human events have often led to error, have stressed certain events too strongly, have minimized others. The complexity of history is selfevident; we must for the present at least content ourselves with complex interpretations of it. If there be any great underlying principles which explain all, they have yet to be discovered.

Thus it would be folly in the study of colonial Virginia to blind ourselves to the importance of various non-economic factors, the love of freedom which the settlers brought with them from England, their affection for the mother country, the influence of the Anglican church. Yet it is obvious that we cannot understand the colony, its social structure, its history, its development unless we have a clear insight into the economic forces which operated upon it. These Englishmen, finding themselves in a new country, surrounded by conditions fundamentally different from those to which they had been accustomed, worked out a new and unique society, were themselves moulded into something different.

And in colonial Virginia history there is a key, which though it may not explain all, opens the door to much that is fundamental. This key is tobacco. The old saying that the story of Virginia is but the story of tobacco is by no means a gross exaggeration. It was this Indian plant, so despised by many of the best and ablest men of the time, which determined the character of the life of the colony and shaped its destinies for two and a half centuries. Tobacco was the chief factor in bringing final and complete failure to the attempts to produce useful raw materials, it was largely instrumental in moulding the social classes and the political structure of the colony, it was almost entirely responsible for the system of labor, it even exerted a powerful influence upon religion and morals. In a word, one can understand almost nothing of Virginia, its in- 
fancy, its development, its days of misfortune, its era of prosperity, its peculiar civilization, the nature of its relations to England, unless one knows the history of tobacco.

As though they had a prophetic vision of its future importance, the Virginia Indians revered the plant. To them it was an especial gift direct from the Great Spirit, and as such was endowed with unusual properties for doing good. When the fields of maize were dried and parched for lack of rain they powdered the tobacco and cast it to the winds that the evil genii might be propitiated; their priests on great occasions fed it to the sacrificial fires; when the usual catch of fish failed it was scattered over the water. ${ }^{x}$ Smoking was considered a token of friendship and peace. When the white men first visited the native villages they soon found that to reject the proffered pipe was to offend their savage hosts and incur their hostility.

It was John Rolfe, celebrated as the husband of Pocahontas, who first experinented with the native leaf. This gentleman was himself fond of smoking, but he found the Virginia tobacco as it came from the hands of the savages, decidedly inferior to that of the West Indies. The leaf itself was small, and although the flavor was weak it was biting to the tongue. ${ }^{2}$ Rolfe's efforts proved entirely successful. In I6I4, two years after his first attempt, he had obtained a product which Ralph Hamor declared to be as "strong, sweet and pleasant as any under the sun."3

Thus, early in its history, Virginia had found a commodity for which she was preëminently suited, in the production of which she could compete successfully with any country in the world. And for her tobacco she had a ready market. During the reign of Queen Elizabeth the habit of smoking had spread rapidly among the upper classes of English, until at the end of the sixteenth century, it was almost universal. When 
James I ascended the throne, although feeling a strong aversion to tobacco, he was forced to take up its use in order not to appear conspicuous among his courtiers, for the dictates of custom seem to have been as strong three hundred years ago as at present. $^{4}$ At the time that Rolfe was making his experiments England was spending yearly for the Spanish product many thousands of pounds.

It is not surprising, then, that the colonists turned eagerly to tobacco culture. The news that Rolfe's little crop had been pronounced in England to be of excellent quality spread rapidly from settlement to settlement, bringing with it new hope and determination. Immediately tobacco absorbed the thoughts of all, became the one topic of conversation, and every available patch of land was seized upon for its cultivation. The fortified areas within the palisades were crowded with tobacco plants, while even the streets of Jamestown were utilized by the eager planters. ${ }^{5}$ In 16 I 7 the George set sail for England laden with 20,000 pounds of Virginia leaf, the first of the vast fleet of tobacco ships which for centuries were to pass through the capes of the Chesapeake bound for Europe. ${ }^{6}$ By 1627 , the tobacco exports amounted to no less than half a million pounds.

The London Company, together with the host of patriotic Englishmen who had placed such great hopes in the colony, were much disappointed at this unexpected turn of events. They had sought in the New World those "solid commodities" which they realized were fundamental to the prosperity of their country, commodities upon which English industrial life was founded. And they had found only the Indian weedtobacco. This plant not only contributed nothing to the wealth of the kingdom, it was felt, but was positively injurious to those who indulged in its use. Surely, declared one writer, men "grow mad and crazed in the brain in that they would 
adventure to suck the smoke of a weed." James I thought there could be no baser and more harmful corruption, while Charles I expressed himself with equal emphasis. So late as 163 I the latter protested against the growing use of tobacco, which he termed "an evil habit of late tymes."

Yet England soon learned to welcome the colonial tobacco as far better than no product at all. Hitherto the leaf in use had been raised in the Spanish colonies, and England's annual tobacco bill was becoming larger and larger. It seemed calamitous that British industry should be drained of good and useful commodities in exchange for a plant the consumption of which was harmful rather than beneficial. It was at least some satisfaction to know, then, that England could substitute for the Spanish leaf the growth of their own colonies. Apparently it was only later, however, that there came a full realization of the opportunity afforded for enriching England and building up her merchant marine by exporting tobacco to foreign countries. For the present they accepted this one product of their experiment in colonial expansion, reluctantly and with keen disappointment, as the best that could be obtained.

Yet it was obvious to the London Company that tobacco held out the only prospect, not only of securing a profit from their venture, but of bringing to Virginia some measure of prosperity. The first consignment of leaf which came from the colony sold for no less than $5 \mathrm{~s}$. $3 \mathrm{~d}$. a pound, a price which promised a rich return to the planters on the James and their backers in England. ${ }^{9}$ And they much preferred to have a prosperous colony, even when prosperity was founded on tobacco, than a weak, impoverished settlement, which would be a drain upon their personal resources and of no value to the nation. Thus they accepted the inevitable, gave what encouragement they could to the new product, and sought to 
use it as a means for building up the British empire in America. When once England had established herself firmly in the New World, it would be time enough to return to the attempt to secure from the colony ship-stores, potash, iron and silk.

With the overthrow of the Company, however, the Crown made repeated efforts to direct the energies of Virginia away from the all-absorbing cultivation of tobacco. In ${ }^{6} 636$ Charles I wrote to the Governor and Council bidding them moderate the excessive quantities of the plant laid out each year and to endeavor to produce some other staple commodities. $^{10}$ "The King cannot but take notice," he reiterated the next year, "how little that colony hath advanced in Staple commodities fit for their own subsistence and clothing," and he warned the planters to emulate the Barbados and Caribee Islands, where a beginning had been made in cotton, wool and other useful things. ${ }^{\mathbf{1}}$ But the colonists paid no heed to these repeated warnings. The King's commands were no more effective in establishing new industries than had been the first attempts of the Company. Virginia was not prepared to compete with the workers of Europe in their own chosen fields, and persisted, had to persist, in the production of the one commodity for which she possessed unsurpassed natural advantages.

It is remarkable how universally the plant was cultivated by all classes of Virginians throughout the colonial period. It was difficult to find skilled artisans in any line of work, since those who had pursued in England the various trades usually deserted them, when they landed in the colony, in order to turn to the raising of tobacco. And the few who continued to pursue their old vocations usually rented or purchased a small tract of land and devoted a part of their time to its cultivation. Blacksmiths, carpenters, shipwrights, 
coopers all raised their little tobacco crop and sold it to the British merchants, ${ }^{12}$ while even the poor minister sought to make ends meet by planting his glebe with Orinoco or Sweetscented. The Governor himself was not free from the allprevailing custom, and frequently was the possessor of a farm where his servants and slaves, like those of other gentlemen in the colony, were kept busy tending the tobacco crop.

It is doubtful whether the members of the London Company, even Sir Edwin Sandys himself, ever attempted to visualize the social structure which would develop in the Virginia they were planning. If so, they unquestionably pictured a state of affairs very different from that which the future held in store. They took it for granted that Virginia would to a large extent be a duplicate of England. In the forests of the New World would grow up towns and villages, centers of industry and centers of trade. The population would be divided into various classes-well-to-do proprietors boasting of the title of gentleman; professional men, lawyers, physicians, ministers; skilled artisans of all kinds; day laborers.

We catch a glimpse of the Virginia of their minds from a Broadside issued in 1610 , appealing for volunteers for service in the colony. ${ }^{13}$ We can see the shipwrights at work in the busy yards of thriving ports; the smelters caring for their iron and copper furnaces; the "minerall-men" digging out the ore; saltmakers evaporating the brackish waters for their useful product; vine-dressers tending their abundant crops of grapes and coopers turning out the hogsheads in which to store the wine which came from the presses; bricklayers and carpenters fashioning substantial houses; fishermen bringing in the plentiful yield of the day and dressers preparing the fish for foreign shipment; joiners, smiths, gardeners, bakers, gun-founders, ploughwrights, brewers, sawyers, fowlers, each plying his trade in the New Brittania. 
But how different was the reality. Virginia became, not an industrial, but a distinctly agricultural community. For more than a century it could boast not a single town worthy of the name. ${ }^{14}$ It was but a series of plantations, not large in extent, but stretching out for miles along the banks of the rivers and creeks, all devoted to the raising of tobacco. The population of the colony was but the aggregate of the population of the plantation - the owner, the wage earners, the indentured servant, a few slaves. Virginia in the Seventeenth century, despite the design of its founders, developed a life of its own, a life not only unlike that of England, but unique and distinct.

Immigration, like everything else in the colony, was shaped by the needs of tobacco. For its successful production the plant does not require skilled labor or intensive cultivation. The barbarous natives of Africa, who later in the century were imported in such large numbers, eventually proved quite adequate to the task. But it does require the service of many hands. For decades after Rolfe's discovery had opened a new vista of prosperity for Virginia, fertile land was so cheap that a person even of moderate means might readily purchase an extensive plantation, ${ }^{15}$ but it would be of little service to him unless he could find hands for clearing away the forests, breaking the soil, tending and curing the plants.

Of the three requirements of production-natural resources, capital and labor-the fertile soil furnished the first in abundance, the second could readily be secured, but the last remained for a full century the one great problem of the planters. From the days of Sir George Yeardley to those of Nicholson and Andros there was a persistent and eager demand for workers. Of this there can be no better evidence than the remarkably high wages which prevailed in the colony, especially in the years prior to the Restoration. In fact, it is probable that the laborer received for his services four or five times the 
amount he could earn in England. Even during the time of the London Company we find George Sandys writing to a friend in London to procure indentured servants for the colony as the wages demanded were intolerable. A day's work brought, in addition to food, a pound of tobacco valued at one shilling, while in England the unskilled worker considered himself fortunate if he could earn so much in a week. ${ }^{16}$

In his efforts to solve this acute problem the planter found little hope in the aborigines. The Spaniards, it is true, had made use of the Indians to till their fields or work in the gold and silver mines, but the Pamunkey and the Powhatan were cast in a different mold from the Aztec and the Peruvian. To hunt them out of their native lairs and bind them to arduous and ignominious servitude was hardly to be thought of. Their spirit was too proud to be thus broken, the safe refuge of the woorls too near at hand. One might as well have attempted to hitch lions and tigers to the plough shaft, as to place these wild children of the forest at the handles. At times it proved practicable to make use of Indian children for servants, and there are numerous instances on record in which they are found in the homes of the planters. ${ }^{17}$ But this, of course, could be of little service in solving the pressing labor problem, in clearing new ground or tilling the idle fields. The Virginia landowner was forced to turn elsewhere for his helpers.

In 1619 a Dutch privateer put into the James river and disembarked twenty Africans who were sold to the settlers as slaves. This event, so full of evil portent for the future of Virginia, might well have afforded a natural and satisfactory solution of the labor problem. Slaves had long been used in the Spanish colonies, proving quite competent to do the work of tending the tobacco plants, and bringing handsome returns to their masters. But it was impossible at this time for England to supply her plantations with this type 
of labor. The slave trade was in the hands of the Dutch, who had fortified themselves on the African coast and jealously excluded other nations. Thus while the demand for negro slaves remained active in the colony, they increased in numbers very slowly. The muster of $1624-25$ shows only $22 .^{18}$ During the following half century there was a small influx of negroes, but their numbers were still too small to affect seriously the economic life of the colony. ${ }^{19}$

The settlers were thus forced to look to England itself to supply them with hands for their tobacco fields. They knew that in the mother country were many thousands of indigent persons who would welcome an opportunity to better their lot by migrating to the New World. And the English statesmen, feeling that there was need for blood letting, welcomed an opportunity to divert the surplus population to the new colony in America. ${ }^{20}$ The decline in English foreign trade and the stagnation of home industry had brought unemployment and suffering to every class of workers. Wages were so low that the most industrious could not maintain themselves in comfort, while to provide against want in case of sickness or old age was hardly to be thought of. Every parish, every town swarmed with persons stricken with abject poverty. In some parts of the country no less than 30 per cent of the population were dependent in part upon charity for their daily bread, while many were driven into vagabondage and crime, becoming an element of danger rather than of strength to the nation. ${ }^{21}$ It seemed to the planters that the mother country constituted an abundant reservoir of labor, a reservoir already overflowing and capable of supplying indefinitely their every need.

The only drawback was the long and expensive voyage across the Atlantic. The fare, even for the poorest and most crowded acconmodations, was no less than six pounds ster- 
ling, a sum far beyond the means of the thriftiest laborer. ${ }^{22}$ Obviously some scheme had to be evolved to overcome this difficulty before Virginia could make use of English labor. And so the planters turned to the simple expedient of advancing the passage money to the immigrant and of placing him under strict legal bonds to work it out after reaching the colony.

This system, around which the economic life of Virginia centered for a full century, proved satisfactory to all concerned. The credit advanced to the immigrant made it possible for him to earn his ocean fare, not in England where labor was cheap, but in America where it was dear. In other words, he was enabled without delay to enjoy the full benefits of selling his services in the best market. The necessity for placing him under a stringent contract or indenture is evident. Had this not been done the immigrant, upon finding himself in Virginia, might have refused to carry out his part of the bargain. But the indenture was in no sense a mark of servitude or slavery. It simply made it obligatory for the newcomer, under pain of severe penalties, to work out his passage money, and until that was accomplished to surrender a part of the personal liberty so dear to every Englishman.

It is erroneous to suppose that most of the servants were degenerates or criminals. It is true that the English Government from time to time sought to lessen the expense of providing for convicted felons by sending some of them to the colonies, among them on rare occasions a few decidedly objectionable characters. More than once the Virginians protested vigorously against this policy as dangerous to the peace and prosperity of the colony. ${ }^{23}$ By far the larger part of these penal immigrants, however, were but harmless paupers, driven perhaps to theft or some other petty offense by cold and hunger. Often they were sentenced to deportation by merci- 
ful judges in order that they might not feel the full weight of the harsh laws of that day. ${ }^{24}$

And of the small number of real criminals who came in, few indeed made any lasting imprint upon the social fabric of the colony. Many served for life and so had no opportunity of marrying and rearing families to perpetuate their degenerate traits. Those who escaped fled from the confines of settled Virginia to the mountains or to the backwoods of North Carolina. Many others sticcumbed to the epidemics which proved so deadly to the newcomers from England. In fact the criminal servant was but a passing incident in the life and development of England's greatest and most promising colony. ${ }^{25}$

An appreciable proportion of the so-called criminal laborers were no more than political prisoners taken in the rebellions of the Seventeenth century. These men frequently represented the sturdiest and most patriotic elements in the kingdom and were a source of strength rather than of weakness to the colony. When Drogheda was captured by Cromwell's stern Puritan troops in 1649 , some of the unfortunate rebels escaped the firing squad only to be sent to America to serve in the sugar or tobacco fields. Just how many of these Irishmen fell to the share of Virginia it is impossible to say, but the number rises well into the hundreds, and the patent books of the period are full of headrights of undoubted Irish origin. ${ }^{26}$

When Charles II was restored to the throne in 1660 it became the turn of the Puritans to suffer, and many non-conformists and former Oliverian soldiers were sent to Virginia. In fact so many old Commonwealth men were serving in the tobacco fields in 1663 that they felt strong enough to plot, not only for their own freedom, but for the overthrow of the colonial government. ${ }^{27}$ In 1678 , after the suppression of the Scottish Covenanters by the Highland Host, a new batch of prisoners were sent to the plantations. ${ }^{28}$ Seven years later 
many of Monmouth's followers taken at Sedgemour, who were fortunate enough to escape the fury of Jeffreys and Kirk, were forced to work in the plantations.

But the bulk of the servants were neither criminals nor political prisoners, but poor persons seeking to better their condition in the land of promise across the Atlantic. They constituted the vanguard of that vast stream of immigrants which for three centuries Europe has poured upon our shores. The indentured servant differed in no essential from the poor Ulsterite or German who followed him in the Eighteenth century, or the Irishman, the Italian or the Slav in the Nineteenth. Like them he found too severe the struggle for existence at home, like them he sought to reach a land where labor, the only commodity he had to sell, would bring the highest return. The fact that his passage was paid for him and that he was bound by contract to work it out after reaching America, in no wise differentiates him from the newcomers of later (ays. In I67I Sir William Berkeley reported to the Board of Trade that the colony contained " 6,000 Christian servants for a short tyme," who had come with the "hope of bettering their condition in a Growing Country." 29

Virginia is fortunate in having preserved a record of this, the first great migration to the English colonics, which in some respects is remarkably complete. In fact, the names of fully three-fourths of all the persons who came to the colony, whether as freemen or servants during the first century of its existence, are on record at the Land Office at Richmond, and at all times available to the student of history. In the early days of the settlement a law was passed designed to stimulate immigration, by which the Government pledged itself to grant fifty acres of land to any person who would pay the passage from Europe to Virginia of a new settler. Thus if one l,rought over ten indentured servants he would be entitled to 
500 acres of land, if he brought Ioo, he could demand 5,000 acres. But the headright, as it was called, was not restricted to servants; if one came over as a freeman, paying his own passage, he was entitled to the fifty acres. Should he bring also his family, he could demand an additional fifty acres for his wife and fifty for each child or other member of the household. ${ }^{30}$

When the Government issued a grant for land under this law, the planter was required to record with the clerk of the county court the names of all persons for whose transportation the claim was made. Some of these lists have been lost, especially for the period from I 655 to I 666 , but most of them remain, constituting an inexhaustible storehouse of information concerning the colony and the people who came to its shores. ${ }^{31}$ How the papers escaped destruction during the fire which did so much damage in the Secretary's office at the time of Andros, it is impossible to say. The explanation is to be found perhaps in the fact that copies of the records were kept, not only at Williamsburg, but in the several counties, so that in case of loss by fire new entries could be made.

Immigration to Virginia continued in unabated volume throughout the Seventeenth century. The needs of the tobacco plantations were unceasing, and year after year the surplus population of England poured across the Atlantic in response. An examination of the list of headrights shows that the annual influx was between $\mathrm{I} 500$ and 2000 . Even during the Civil War and Commonwealth periods this average seems to have been maintained with surprising consistency. Apparently the only limit which could be set upon it was the available space on board the merchant fleet which each year left England for the Chesapeake bay. Thus in the year ending May 1635 we find that 2000 landed in the colony, ${ }^{32}$ while in I674 and again in I682 the same average was maintained. ${ }^{33}$ 
At times the numbers dropped to I 200 or 1300 , but this was the exception rather than the rule. All in all, considerably more than 100,000 persons migrated to the colony in the years that elapsed between the first settlement at Jamestown and the end of the century. ${ }^{34}$

This great movement, which far surpassed in magnitude any other English migration of the century, fixed for all time the character of the white population of tidewater Virginia. The vast bulk of the settlers were English. An examination of the headright lists shows here and there an Irish or a Scotch name, and on very rare occasions one of French or Italian origin, but in normal periods fully 95 per cent were unmistakably Anglo-Saxon. In fact, such names as Dixon, Bennett, Anderson, Adams, Greene, Brooke, Brown, Cooper, Gibson, Hall, Harris, King, Jackson, Long, Martin, Miller, Newton, Philips, Richards, Turner, White, appear with monotonous repetition. Except in the years ${ }_{6} 655$ and $I 656$, after the Drogheda tragedy when one sees such names as O'Lanny, O'Leaby, O'Mally, and Machoone, or in I679 when there was a sprinkling of Scottish names, the entire list is distinctly English.

It must not be supposed that immigration to Virginia in the Seventeenth century was restricted to indentured servants. Some of the settlers were freemen, paying their own passage and establishing themselves as proprietors immediately after arriving in the colony. But the conditions which attracted them were the same as those which brought over the servants. In both cases it was tobacco, the rich returns which it promised and the urgent need it had of labor, which impelled them to leave their homes in England to seek their fortunes in the strange land beyond the seas.

Having seen the character of the immigration to Virginia, it remains to determine what was the fate of the settler after he 
reached the colony, what rôle lay before him in its social and economic life. Would he remain permanently in the status of a servant, entering into a new agreement with his master after the expiration of the old? Would he eventually become a day laborer, working for wages upon the estates of the wealthy? Would he become a tenant? Could he hope to become a freeholder, making of Virginia, like Rome in the early days of the republic, the land of the small proprietor? 


\section{CHAPTER III}

\section{Tiie Virginia Yeomanry}

ThE system of inclentured labor differed vitally from negro slavery. The servant usually was bound to his master for a limited period only, and at the expiration of four or five years was a free man, to go where he would and pursue what employment seemed most lucrative. And of tremendous importance to the future of Virginia was the fact that he was of the same race and blood as the rest of the population. There was no inherent reason why he might not take up land, marry and become a part of the social structure of the colony.

When races of marked physical differences are placed side by side in the same territory, assimilation of one or the other becomes difficult, and an age long repugnance and conflict is apt to result. Perhaps the greatest crime against the southern colonies was not the introduction of slavery, but the introduction of negroes. It was inevitable that eventually slavery would be abolished. But the negro race in America cannot be abolished, it cannot be shipped back to Africa, it cannot well be absorbed into the white population. Today California is struggling to avoid a like problem by excluding the Japanese, while Canada, Australia and New Zealand are closing their doors to Orientals of all kinds.

Thus Virginia, during its century of white immigration, was storing up no perplexing difficulties for the future, was developing slowly but surely into an industrious, democratic, Anglo-Saxon community. Not until the black flood of slaves was turned loose upon her, strangling her peasantry and revolutionizing her industrial and social life, was her future put 
in pawn. The white servants, so far as they remained in the colony, became bone of her bone, flesh of her flesh, promised her a homogeneous race, a sound economic and political development.

When the alien newcomer to the United States sees from the deck of his steamer the Statue of Liberty and the ragged sky line of lower Manhattan, he feels that the goal of his ambition has been reached, that the land of opportunity lies before him. But to the indentured settler of the Seventeenth century, his arrival in the Janes or the York was but the beginning of his struggles. Before he could grasp the riches of the New World, he must pay the price of his passage, must work out through arduous years the indenture to which he had affixed his signature.

And these years were filled not only with toil, perhaps with hardship, but with the greatest peril. He might account himself fortunate indeed if during the first twelve months he escaped the so-called Virginia sickness. Tidewater Virginia for the English settlers was a pest-ridden place. The low and marshy ground, the swarming mosquitoes, the hot sun, the unwholesome drinking water combined to produce an unending epidemic of dysentery and malaria. And at frequent intervals, especially in the early years, yellow fever, scurvy and plague swept over the infant colony, leaving behind a ghastly train of suffering and death. ${ }^{1}$ At one time the mortality among the settlers upon the James ran as high as 75 per cent and for a while it seemed that this attempt of the British nation to secure a foothold upon the American continent must end in failure. ${ }^{2}$

But as the years wore on better conditions prevailed. Governor Berkeley testified in I67I, "there is not oft seasoned hands (as we term them) that die now, whereas heretofore not one of five escaped the first year." 3 This improvement 
was brought about by the use of Peruvian bark, a clearer understanding of sanitary matters and the selection of more healthful sites for plantations. At the time when Sir William wrote it is probable that 80 per cent or more of the indentured servants survived the dangers of the tobacco fields, completed their terms of service and, if they remained in the colony, became freedmen with the full rights of Englishmen and Virginians.

In the period from 1660 to 1725 there was, as we shall see, an exodus of poor whites from Virginia. This, however, was cliefly the result of the influx of slaves which marked the end of the century, and it is safe to assume that prior to the Restoration there was no extensive movement from Virginia to other colonies. The servant, upon attaining his freedom, usually remained in the colony and sought to establish himself there.

Although it is impossible to determine accurately the average length of service required by the indentures, there is reason to believe that it did not exceed five years. In cases of controversy between masters and servants who had come in without written contracts as to when their terms should expire, it was at first required by law that the period be fixed at five years if the age was in excess of twenty-one." In I654, however, a new act was passed by the Assembly, making it necessary for those who had no indentures, if over sixteen to serve six years, if less than sixteen until the twenty-fourth year had been reached. ${ }^{5}$ This was found to work to the disadvantage of the colony by discouraging immigration, and in I662 the law was changed so that in all doubtful cases the legal term should be five years for persons over sixteen. ${ }^{\circ}$ Since the Assembly, which was so largely made up of persons who themselves held servants, would certainly not fix the legal term for a period shorter than that normally provided 
for in the indentures, we may assume that usually the servant secured his freedom within four or five years after his arrival in the colony.

Thus it is evident that the bulk of the population could not have been, as is so often supposed, made up of large landed proprietors with their servants and slaves. Such a conception takes no account of the annual translation of hundreds of men and women from bondsmen into freedmen. The short duration of the average term of service, together with the fact that the servants were usually still young when freed, made it inevitable that in time the freedmen would outnumber those in service. The size of the annual immigration could in no wise alter this situation, for the greater the influx of servants, the greater would be the resulting graduation into the class of freedmen.

The average number of headrights, as we have seen, was probably not less than $I 75^{\circ}$ a year. If it is assumed that I 500 of these were servants, five per cent of whom served for life and 20 per cent died before the expiration of their terms, no less than I 25 would remain to become freedmen. While the number of those under indenture remained practically stationary, the size of the freedman class grew larger with the passing of the years.

Placing the average term at five years, then, and the average mortality at twenty per cent, there would be in service at any given time some 6,000 men and women. In fact, Sir William Berkeley, in his fanous report of I67I, estimated the number of servants in the colony at this figure. ${ }^{7}$ On the other hand an annual accession of II 25 to the class of freedmen would in five years amount to 5,625 , in ten years to $11,25^{\circ}$, in fifteen to 16,875 , in twenty to 22,500 . At the end of half a century no less than $56,25^{\circ}$ persons would have emerged from servitude to become free citizens. Although there is 
every reason to believe that these figures are substantially correct, ${ }^{8}$ their accuracy or lack of accuracy in no way affect the principle involved. From its very nature it was impossible that the system of indentured servants should long remain the chief factor in the industrial life of the colony or supply most of the labor.

It is true, of course, that the number of those completing their terms of indenture is not an absolute gauge, at any given date, of the size of the freedman class. To determine this it would be necessary to know the average span of life of the freedman, a thing certainly not worked out at the time and impossible of accomplishment now. We may assume, however, that it was relatively long. The newcomer who had lived through the first terrible year in the tobacco fields had been thoroughly tested, "seasoned" as the planters called it, and was reasonably certain of reaching a mature age. Moreover, the servants were almost universally of very tender years. Seldom indeed would a dealer accept one over twenty-eight, and the average seems to have been between seventeen and twenty-three. The reasons for this are obvious. Not only were young men and women more adaptable to changed conditions, more capable of resisting the Virginia climate, stronger and more vigorous, but they proved more tractable and entered upon the adventure more eagerly. ${ }^{9}$ These conclusions are fully borne out by an examination of the lists of servants given in Hotten's Emigrants to America. Of the first I 59 servants here entered whose ages are attached, the average is twenty-three years. ${ }^{10}$ And as many of these persons were brought over as skilled artisans to take part in the industrial life which the Company had planned for the colony, it is probable that they were much older than the average servant of later days who came as an agricultural laborer. There is every reason to believe, then, that the average servant 
was still in his prime when he completed his term, perhaps not more than twenty-six or twenty-seven, with many years of usefulness and vigor before him.

It must also be remembered that the freedman, by a display of energy and capability, might acquire property, marry and rear a family. While the number of indentured servants was strictly limited to those who were brought in from the outside, the class of poor freemen might and did enjoy a natural increase within itself. Thus it was inevitable that with the passing of the years the servants were more and more outnumbered by the growing group of freemen. In I 649 , when the population was but ${ }^{1} 5,000,{ }^{11} 6$,ooo servants might well have performed most of the manual labor of the tobacco fields, but in 1670 , when the inhabitants numbered $40,000,{ }^{12}$ or in 1697 when they were $70,000,{ }^{13}$ they would form a comparatively small proportion of the people, so small in fact that most of the work of necessity had to be done by freemen. In other words the picture so often presented, even by historians of established reputation, of a Seventeenth century Virginia in which the land was divided into large plantations owned by rich proprietors and tilled chiefly by indentured servants is entirely erroneous. Such a state of affairs was made impossible by the very nature of the system of indentures itself.

It becomes a matter of prime interest, then, to determine what became of the mass of freedmen, what role they played in the social and economic life of the colony. Because the servant who had completed his term was free to follow his own bent, we have no right to assume that he sought at once to establish himself as an independent proprietor. He might seek service with the large planters as a hired laborer, he might become a tenant. In either case the population would have been divided into two classes-the wealthy landowner and those who served him. 
We know that at all periods of Virginia history there were a certain number of persons employed as wage earners. The colonial laws and the county records contain many references to them. Payment of wages was not unusual even under the Company, and we are told by George Sandys that hired laborers received one pound of tobacco a day in addition to their food. ${ }^{14}$ In later years we have from time to time references to wage rates, and in some cases copies of contracts entered into between employer and wage earner. But such cases are comparatively rare, and it is evident that the use of hired labor throughout the colonial period was the exception rather than the rule. In fact it would seem that few save servants newly freed and lacking in the funds necessary for purchasing and equipping little farms of their own ever sought employment upon the large plantations. And even in such cases the contracts were for comparatively short periods, since it often required but a year or two of labor for the freedman to save enough from his wages to make a beginning as an independent proprietor.

When once established, there was no reason, in the days prior to the introduction of slavery, why he should not hold his own in competition with his wealthy neighbor. In the production of tobacco the large plantation, so long as it was cultivated only by expensive white labor, offered no marked advantage over the small. With the cost of land very low, with the means of earning the purchase price so readily in hand, with the conditions for an independent career all so favorable, it was not to be expected that the freedman should content himself permanently with the status of a hired laborer.

Nor was there any reason why he should become a tenant. Had all the fertile land been preempted, as was the case on the banks of the Hudson, the poor man might have been compelled to lease the soil upon which he expended his efforts or 
do without entirely. But such was not the case. It is true that at the end of the Seventeenth century certain wealthy men got possession of large tracts of unsettled land, but their monopoly was so far from complete that they gladly sold off their holdings in little parcels to the first purchasers who presented themselves. Apparently they made no attempts to establish themselves in a position similar to that of the great landlords of England.

The records afford ample evidence that the leasing of property was by no means unknown in colonial Virginia, but the custom was comparatively rare. Hugh Jones, writing in $I 72 \mathrm{r}$, declared that the tenant farmers constituted but a small fraction of the population, a fact which he explained by the unusual facilities for acquiring property in fee simple. ${ }^{15}$ It would have been folly for the tobacco planter to expend his labor upon another man's property, perhaps erecting barns and fences and otherwise improving it, when he could for so small an outlay secure land of his own.

Thus we are led to the conclusion that the average Virginia plantation must have been comparatively small in extent. The development of large estates was narrowly limited by the various factors which made it impossible to secure an adequate labor supply-the restrictions upon the slave trade, the insufficient number of indentured servants and the shortness of their terms, the unwillingness of freedmen and others to work for wages. On the other hand, it would be expected that the servants upon securing their freedom would purchase land of their own, and cover all tidewater Virginia with little farms.

Turning to the various records of the time that deal with the distribution of land-deeds, wills, transfers, tax lists, inventories-we find that these conclusions are fully borne out. All reveal the fact that the average plantation, especially in the Seventeenth century, so far from vieing with the vast estates 
in existence in certain parts of America, was but a few hundred acres in extent.

The land transfers of Surry county afford an interesting illustration. In thirty-four instances mentioned during the years from 1684 to $I 686$, for which the exact number of acres is given, the largest is 500 acres, the smallest twenty. The aggregate of all land which changed hands is 6,355 acres, or an average of 187 for each sale. There are eleven transfers of 100 acres or less, twenty-three transfers of 200 or less and only four of more than 300 acres. ${ }^{16}$ One can find in this no evidence of the fabled barons of colonial Virginia, but only of a well established class of small proprietors.

The York county books for the years from I696 to I70I tell the same story. Here we find recorded forty-one transfers and leases. Twenty-two are for 100 acres or less, 33 for 200 acres or less, and four, one for 1,400 , one for 1,210 , one for 600 and one for $55^{\circ}$, are more than 300 acres in extent. The aggregate is 8, 53 acres and the average $199 .{ }^{17}$

In the Rappahannock county records from I 680 to I 688 of fifteen land transfers taken at random from the books, the largest is 400 while the average is I 68 acres. ${ }^{18}$ Of the fortyeight transfers mentioned in the Essex county books for the years from 1692 to $I 695$, the largest is 600 acres and the smallest 50. Twenty are for Ioo acres or less, 3 I for 200 or less and only four for over $300 .{ }^{19}$

That conditions not fundamentally different prevailed in the early days of the colony is shown by the census taken of the landowners in 1626 . Of the holdings listed no less than 25 were for 50 acres or less, 73 for 100 and most of the others for less than 300 acres. The total number of proprietors listed is 224 and the total acreage 34,472 , giving an average for each plantation of $\mathrm{r} 54$ acres. ${ }^{20}$

It has been assumed by certain writers that the land grants 
preserved in the Registrar's Office in Richmond tend to contradict this evidence. Although the average patent is by no means large, it is much more extensive than the typical land transfer. In 1638 this average was 423 acres, in 1640 it was 405 , in 1642 it was 559 , in 1645 it was 333 , in 1648 it was 412 , in 1650 it was 675 . During the entire period from 1634 to 1650 inclusive the size of the average land grant was 446 acres. From 1650 to 1655 the average was $59 \mathrm{I}$ acres, from I 655 to I666 six hundred and seventy-one, from I 666 to 1679 eight hundred and ninety acres, from I 679 to 1689 six hundred and seven acres, from I689 to I 695 six hundred and one acres, from 1695 to 1700 six hundred and eighty-eight acres. ${ }^{21}$ In the course of the entire second half of the Seventeenth century the average size of the patent was 674 acres.

Yet these facts have little direct bearing upon the extent of the plantations themselves. The system of granting land, as we have seen, was not based upon the individual needs of the planters, but upon the number of headrights presented to the Government. Obviously it was the question of the most economical method of transporting immigrants which would determine the average size of the grant. If it proved best to bring in servants in small groups, distributed among vessels devoted chiefly to merchandise, the patents would be small; if they came in on immigrant vessels, in numbers ranging from 50 to 200 , the patents would be large.

Apparently both methods were in vogue. There are grants recorded varying in size from 50 acres to Io,000 acres. ${ }^{22}$ Beyond doubt many merchants, finding that their vessels on the western voyage were not fully laden, from time to time took on a few indentured servants. If they furnished accommodation for from ten to twenty immigrants, they could demand, in addition to the sale of the indentures, 500 to $\mathrm{I}, \mathrm{OOO}$ acres of land. It was a frequent practice, also, for planters in Vir- 
ginia to send orders to their agents in England to procure and ship one or more servants as need for them arose. "Your brother George hath moved you in his letters to send him over some servants the next year," wrote Richard Kemp to Robert Read in $1639 .{ }^{24}$ Undoubtedly in cases of this kind the servants usually sailed in small parties upon the regular merchant vessels.

On the other hand it would appear that large numbers of persons arrived on strictly immigrant vessels, in which they made the chief if not the only cargo. Some of the best known men in the colony were dealers in servants and reaped from the business very large profits. Of these perhaps the best known in the earlier period was William Claiborne, celebrated for his dispute with the Maryland proprietors over the possession of Kent Island. Peter Ashton was another extensive dealer in servants, at one time receiving $2,55^{\circ}$ acres for his headrights, at another 2,00o. Isaac Allerton, Lewis Burwell, Giles Brent, Joseph Bridger and many others of like prominence are upon the patent rolls for large grants. The most inveterate dealer in servants, however, was Robert Beverley. This well known planter, so famous for his part in Bacon's Rebellion and in the political contests which grew out of it, is credited with patents aggregating 25,000 or 30,000 acres. $^{25}$

Often partnerships were formed for the importation of servants, in which cases the patents were made out jointly. Among the more interesting are patents to Robert Beverley and Henry Hartwell, to Thomas Butt and Thomas Milner, to William Bassett and James Austin, to Thomas Blunt and Richard Washington. When associations of three or more persons were formed for the importation of servants, a not infrequent occurrence, the number of headrights is unusually large and the grants patented in consequence extensive. Thus 
Edmund Bibbie and others are credited with 3,350 acres, Robert Ambrose and others with 6,000, George Archer and others with $4,000 .^{26}$

It is clear, then, that the size of the average patent in the Seventeenth century is not an indication of the extent of the average plantation. If economic conditions were such as to encourage large holdings, extensive farms would appear regardless of the original patents, for the small proprietors would be driven to the wall by their more wealthy rivals and forced to sell out to them. On the other hand, if the large planters found it difficult to secure adequate labor they would of necessity have to break up their estates and dispose of them to the small freeholders. That the latter development and not the former actually took place in Virginia during the Seventeenth century a careful examination of the country records makes most apparent.

Over and over again in the records of various land transfers it is stated that the property in question had belonged originally to a more extensive tract, the patent for which was granted under the headright law. A typical case is that of John Dicks who purchased for 8,500 pounds of tobacco, "all the remaining part of 900 acres gotten by the transporting of I9 persons." ${ }^{27}$ Similarly we find John Johnson in r653 selling to Robert Roberts half of 900 acres which he had received by patent. ${ }^{28}$ In 1693 John Brushood sold to James Grey 200 acres, a part of 5, IOO acres originally granted to Mr. Henry Awbrey. ${ }^{29}$ Such cases could be multiplied indefinitely.

Perhaps the most instructive instance left us of this development is the break up of a tract of land known as Button's Ridge, in Essex country. This property, comprising 3,650 acres, was granted to Thomas Button in the year $1666 .^{30}$ The original patentee transferred the entire tract to his brother Robert Button, who in turn sold it to John Baker. The lat- 
ter, finding no doubt that he could not put under cultivation so much land, cut it up into small parcels and sold it off to various planters. Of these transactions we have, most fortunately, a fairly complete record. To Captain William Moseley he sold 200 acres, to John Garnet 600, to Robert Foster 200, to William Smither 200, to William Howlett 200, to Anthony Samuell 300, to William IVilliams 200. It is probable that he sold also a small holding to Henry Creighton, for we find the latter, in 1695 , transferring to William Moseley IOO acres, formerly a part of Button's Ridge. ${ }^{31}$

Important as are these gleanings from the county records, we have at our disposal even better and more conclusive evidence that colonial Virginia was divided, not into baronial estates of vast proportions, but into a large number of comparatively snall farms. Governor Nicholson's rent roll, which is published as an appendix to this volume, for the early years of the Eighteenth century at least, places the matter beyond doubt. Here we have before us an official inventory of all Virginia save the Northern Neck, giving the name of every proprietor and the number of acres in his possession.

It will be remembered that in the Crown colonies there was a perpetual obligation imposed upon all land when first granted known as the quit-rent. In Virginia this duty amounted to one shilling for every fifty acres, payable in tobacco at the rate of a penny per pound. ${ }^{32}$ Despite the fact that some 27 per cent of the returns was consumed by the cost of collection, and that there were frequent frauds in disposing of the tobacco, the revenue derived from this source was of considerable importance. ${ }^{33}$ The amount collected in $\mathrm{I} 705$ was $£ \mathrm{I}, 84 \mathrm{I}$. I. $63 / 4$. When James Blair, the Virginia Commissary of the Bishop of London, petitioned William and Mary for a fund from the accumulated quit-rents for his proposed college at Villiamsburg, some of the British governmental officials ob- 
jected strenuously. "This sum is perhaps the only ready cash in all the plantations," it was declared, "which happens to be by good husbandry and is a stock for answering any emergency that may-happen in Virginia. ${ }^{.{ }_{34}}$

Throughout the entire Seventeenth century, however, the Governors had experienced great difficulty in collecting this tax. Over and over again they reported in their letters to the Board of Trade that there were large arrears of quit-rents which it was impossible to make the landowners pay. ${ }^{35}$ The reason for this was obvious enough. In each county the tax collector was the sheriff. Although this officer was appointed by the Governor, he usually had a wholesome respect for the larger proprietors and in consequence was wary of giving offense by holding them to too strict an account of their estates. ${ }^{36}$ At times the sheriffs themselves were the sufferers by this state of affairs, for they were held responsible for the rents upon all land patented in their counties, for which returns had not been made.

Although the Governors from time to time made rather feeble attempts to remedy the prevailing laxness in this matter, nothing of importance was accomplished before the first administration of Francis Nicholson. The chief executive himself had much need of the good will of the richer inhabitants, and he was not over forward in forcing them to bring in accurate returns. Nicholson, however, who prided himself on his executive ability and who was bent on breaking the power of the clique which centered around the Council of State, exerted himself to the utmost to secure full payment for every acre.

So early as 1690 we find him issuing orders to the sheriffs for the drawing up of an accurate rent roll, through an examination of the patent lists and the records of land transfers. ${ }^{37}$ May I 5. I69I, he took up the matter again, warning the sheriffs 
that he expected more accurate returns than they had yet made. ${ }^{38}$ With the appointment of Sir Edmund Andros as Governor, however, interest in the quit-rents lapsed, and not until his removal and the reappointment of Nicholson was the attempt resumed.

In July, I 699, Nicholson wrote the Commissioners of Trade and Plantations that he was doing his best to improve the quit-rents and that the auditor had been ordered to draw up a scheme for securing a more exact list of land holdings. ${ }^{39}$ But for a while the matter still hung fire. The leading men in the Government were ready enough in making suggestions, but they were extensive landholders themselves and apparently rendered no real assistance. "I have considered those papers given me by your Excellency relating to a perfect rent roll," the auditor, William Byrd I wrote Nicholson, Oct. 21, I7O3, "notwithstanding I have, according to your repeated directions used my utmost diligence in giving charge to sheriffs and taking their oaths to rolls, I am sensible there is still very great abuse therein." ${ }^{40}$

Despite these discouragements Nicholson persisted and in I704 succeeded in obtaining the first really accurate rent roll of the colony. These lists have long been missing, and perhaps were destroyed in one of the several fires which have wrought so much havoc with the records of colonial Virginia, but a true copy was made by the clerk, William Robertson, and sent to the Board of Trade. Fortunately the British Government has been more careful of its priceless historical manuscripts than has Virginia, and this copy today reposes in the Public Record Office in London, a veritable treasure trove of information concerning economic and social conditions in the colony. ${ }^{41}$

Even a cursory examination of the rent roll is sufficient to dispel the old belief that Virginia at this time was the land 
of the large proprietor. As one glances down the list of plantations he is struck by the number of little holdings, the complete absence of liuge estates, the comparative scarcity even of those that for a newly settled country might be termed extensive. Here and there, especially in the frontier counties is listed a tract of four or five or even ten thousand acres, but such cases are very rare. In Middlesex county there is but one plantation of more than 2,500 acres, in Charles City county the largest holding is 3, I30, in Nansemond 2,300, in Norfolk county 3,200, in Princess Anne 3,100, in Elizabeth City county 2, I4O, in York 2,750, in Essex 3,200.

On the other hand the rolls reveal the existence of thousands of little proprietors, whose holdings of from 50 to 500 acres embraced the larger part of the cultivated soil of the colony. Thus we find that in Nansemond, of 376 farms 26 were of 50 acres or less, 66 were between 50 and ioo acres, I ro between 100 and 200 acres, 88 between 200 and 400 acres, 78 between 400 and I,000 acres, and only eight over I,000 acres. In Middlesex county out of I 22 holdings eleven were of $5^{\circ}$ acres or less, 33 between 50 and IoO acres, 32 between 100 and 200 acres, 25 between 200 and 500 acres, I 9 between 500 and 2,500 acres, one of 4,000 acres and one of 5,200 acres. Of the 94 plantations in Charles City county 26 were of 100 acres or less, 21 between 100 and 200 acres, 25 between 200 and 500 acres, 19 between 500 and 2,500 acres and three more than 2,500 acres. ${ }^{42}$

Although the average size of the plantations varied considerably in different counties it was everywhere comparatively small, far smaller than the average land grant of the time, far smaller than has been imagined by some of the closest students of the period. For Nansemond the rolls reveal the average holding as 212 acres, for James City county 400, for York 298, for Warwick 308, for Elizabeth City county 255, 
for Princess Anne 459, for Gloucester 395, for Middlesex 406, for Charles City county $553 .^{* 3}$

In the past few decades much has been written of the social life and custons of the people of colonial Virginia. But except in the able works of Dr. Philip Alexander Bruce little has been said concerning the small planter class, the men who made up the vast bulk of the population, the true Seventeenth century Virginians. We lave long and detailed descriptions of the residences of the small group of the well-to-do, their libraries, their furniture, their table ware, their portraits, their clothing, their amusements. The genealogy of the leading families has been worked out with minute care, their histories recorded, some of their leading members idealized by the writers of fiction. The mention of colonial Virginia brings instantly to mind a picture of gay cavaliers, of stately ladies, of baronial estates, of noble manors. And the sturdy, independent class of small farmers who made up a full 90 per cent of the freeholders at the time the rent roll was taken, have been relegated into undeserved obscurity.

It is to be noted that the roll does not include the names of proprietors residing in the Northern Neck, as the peninsula between the Potomac and the Rappahannock is called. This territory, although acknowledging the jurisdiction of the Government at Williamsburg in most matters and sending representatives to the House of Burgesses, paid its quit-rents, not to the Crown but to a proprietor. Nicholson, therefore, was not concerned in their collection and took no steps to list its landholders in his new roll. There is no reason to believe, however, that conditions in that part of the colony were fundamentally different.

Nor can the accuracy of the rent roll be challenged. There existed always the incentive to make false returns, of course, in order to escape the payment of taxes, and not many sheriffs 
were so diligent as the one in Henrico who unearthed 1,669 acres that had been "concealed." ${ }^{\prime 4}$ Yet it must be remembered that the Governor brought to bear all the pressure at his disposal to make this particular roll accurate, that the sheriffs were his appointees, that they could not lightly defy him in so important a matter. And even though in isolated cases they may have winked at false returns from men of wealth and rank, from the mass of small proprietors they must have insisted upon reports as accurate as the records or actual surveying could make them. No doubt certain uncultivated tracts in the frontier counties were omitted, but with these we are not immediately concerned. For conditions in the older parts of the colony, where the slow evolution of economic factors had been at work for a century, the roll presents unimpeachable evidence that the bulk of the cultivated land was divided into small plantations.

But it still remains to prove that their owners were men of meagre fortunes, men who tilled the soil with their own hands. After all a farm of two or three hundred acres might give scope for large activities, the employment of many servants and slaves, the acquisition of some degree of wealth. Might it not be possible that though the acres of the planter were limited, his estate after all corresponded somewhat with the popular conception?

This leads us to a study of the distribution of servants and slaves among the planters. At the outset we are faced with convincing evidence that at the end of the Seventeenth century the average number for each farm was very small. This is shown by a comparison of the number of plantations listed in the rent roll of $\mathrm{I}_{704}$ with the estimated number of workers. In the counties for which the sheriffs made returns for Governor Nicholson there were some 5,500 landholders. IVhen to these is added the proprietors of the Northern Neck the 
number must have approximated 6,500. If at this time the servants numbered 4,000 , as seems probable, ${ }^{45}$ and the slaves 6,000 , together they would have averaged but 1.5 workers for each plantation. A decade earlier, when the use of slaves was still comparatively infrequent, the figure must have been still lower.

Fortunately we have even more direct and detailed evidence. Throughout almost all of Virginia colonial history one of the chief methods of raising revenue for the Government was the direct poll tax. This levy was laid, however, not only on every freeman over sixteen years of age, but upon male servants over 14 , female servants who worked in the fields, and slaves above 16 of either sex, all of whom were officially termed tithables. $^{48}$ The tax rolls in which these persons were listed, some of which have been preserved among the county records, throw much light upon social and economic conditions in the colony.

In one district of Surry county we find in the year 1675 that there were 75 taxpayers and only I 26 tithables. In other words only $5 \mathrm{I}$ persons in this district had this duty paid for them by others, whether parents, guardians or masters. And of the taxpayers, forty-two were liable for themselves alone, having no servants, slaves or dependent sons over I6; fifteen were liable for one other person, eight for two others, and only one, Lieutenant-Colonel Jordan, for so many as seven. ${ }^{47}$

In other districts the story is the same. In one there were forty taxpayers, 75 tithables and 25 persons who paid for themselves alone; in another 28 taxpayers, 62 tithables, fifteen who had no servants or slaves; in a third 48 taxpayers, 83 tithables, 28 who paid only for themselves, eleven who paid for two, five who paid for three; in a fourth district 29 taxpayers, 63 tithables, fourteen who had no servants or slaves; in a fifth 25 taxpayers, 45 tithables, 12 who paid only for 
themselves. ${ }^{48}$ Thus in Surry county in the year 1675 there were in all 245 taxpayers and 434 tithables. In other words the men who paid their own tax outnumbered all those whose tax was paid for them, whether servants, slaves or relatives, at the ratio of about 4 to 3 .

A study of the records of the same county ten years later leads to almost identical results. At that time Surry seems to have been divided into four districts. In the first there were 78 taxpayers, I 32 tithables, 30 persons who paid only for themselves; in the second, 63 taxpayers, I 33 tithables, 33 persons who paid for themselves alone; in the third there were 38 taxpayers, 74 tithables and 22 persons paying only for themselves; in the fourth I25 taxpayers, 20I tithables and 8I persons having no dependents to pay for. Thus there were 540 tithables in all and 304 taxpayers. In the entire county there were about 122 persons who paid the poll tax for others. The largest holders of servants or slaves were Mr. Robert Randall with seven, Lieutenant-Colonel William Browne with nine, Mr. Robert Canfield with seven, Mr. Arthur Allen with six, Mr. William Edwards with six, Mr. Francis Mason with seven and Mr. Thomas Binns with eight. ${ }^{49}$

Here again is proof that the popular conception of the Virginia plantation life of the Seventeenth century is erroneous. Instead of the wealthy planter who surrounded himself with scores of servants and slaves, investigation reveals hundreds of little farmers, many of them trusting entirely to their own exertions for the cultivation of the soil, others having but one or two servants, and a bare handful of well-to-do men each having from five to ten, or in rare cases twenty or thirty, servants and slaves.

A further confirmation of these conclusions is to be had by comparing the number of plantations listed in the rent roll of I 704 with the official returns of tithables for $1702 .^{50}$ Thus in 
Nansemond there were 375 plantations and 1,030 tithables, Henrico with 162 plantations had 803 tithables. Middlesex with I 22 plantations had 8 I t tithables, Gloucester with $38 \mathrm{I}$ plantations had 2.620 . James City with 28 ; plantations had I.193. York with 205 plantations had I, I8o, Warwick with I 22 plantations had 505. Elizabeth City with I 6 plantations had 47 . Frincess tnne with 2 I 5 plantations had 727 , Surry with 273 plantations had 739. Isle of Wight with 262 plantations had 896. Norfolk with 303 plantations had 693, New Kent with 49 ; plantations had 1,245 . King Villiam with 217 plantations had So3. King and Queen with fo3 plantations had I.845. Essex with 370 plantations had 1.034. Accomac with 392 plantations had I.O4I. Northampton with 258 plantations had 693. Charles City and Prince George together with 420 plantations had 1.327 .51

In Nansemond the average number of tithables as compared with the number of plantations was 2.7. in Henrico 5.1, in Middlesex 6.7, in Gloucester 6.9, in James City 4.2, in York 5.7. in Warwich 4.I, in Elizabeth City 4 , in Princess Anne 3.4. in Surry 2.7, in Isle of Wight 3.3. in Noriolk 2.3. in New Kent 2.5. in King Milliam 3.7. in King and Queen 4.6, in Essex 2.8, in Accomac 2.6. in Northampton 2.3. in Charles City and Prince George combined 3.I. In all Virginia, with the exclusion of the Northern Neck, there were 19,7 i 5 tithables and some 5.500 plantations, an average of 3.6 tithables for each plantation. If we deduct from the tithables all the male ireeholders included in the rent roll, there remains only some i 4.700 persons south of the Rappahannock to make up the list, not only oi serrants and slaves, but of professional men, wage earners, artisans and dependent sons of landholders over 16 years of age.

Another invaluable source of information concerning the distribution of servants and slaves is provided by the numer- 
ous inventories, deeds, and wills which have been preserved in the records. Thus in Surry during the years from I67 I to I 686 we find listed the estates of fifty-nine persons. Of these no less than fifty-two were apparently without servants or slaves; two, William Rooking and Captain Robert Spencer, had five each; one, Mr. William Chambers, had three; and four, Captain William Corker, John Hoge, Mr. John Goring and Samuel Cornell, had one each. ${ }^{52}$

In Elizabeth City of twenty-seven estates recorded during the years from 1684 to 1699 sixteen were without servants or slaves; of twenty-six recorded in York during the period from I 694 to 1697 thirteen had no servants or slaves; of twentythree recorded in Henrico from 1677 to 1692 fourteen were without servants or slares. ${ }^{53}$ It is true that these inventories and wills, since they would usually pertain to persons of advanced age, perhaps do not furnish an absolutely accurate gauge of the average number of servants held by each planter. On the other hand, it is equally probable that a larger proportion of big estates than of the small found their way into the records. At all events it is evident that a goodly proportion of the landholders, perhaps sixty or sixty-five per cent possessed no slaves or indentured servants, and trusted solely to their own exertions for the cultivation of their plantations.

Thus vanishes the fabled picture of Seventeenth century Virginia. In its place we see a colony filled with little farms a few hundred acres in extent, owned and worked by a sturdy class of English farmers. Prior to the slave invasion which marked the close of the Serenteenth century and the opening of the Eighteenth, the most important factor in the life of the Old Dominion was the white yeomanry. 


\section{CHAPTER IV}

Freemen and Freedmen

I $\mathrm{T}$ is obvious that the small planter class had its origin partly in the immigration of persons who paid their own passage, partly in the graduation into freedmen of large numbers of indentured servants. But to determine accurately the proportion of each is a matter of great difficulty. Had all the records of Seventeenth century Virginia been preserved, it would have been possible, by means of long and laborious investigation, to arrive at strictly accurate conclusions. But with the material in hand one has to be satisfied with an approximation of the truth.

It must again be emphasized that the indentured servants were not slaves, and that at the expiration of their terms there was 110 barrier, legal, racial or social to their advancement. The Lords of Trade and Plantations, in I676, expressed their dissatisfaction at the word "servitude" as applied to them, which they felt was a mark of bondage and slavery, and thought it better "rather to use the word service, since those servants are only apprentices for years." "Malitious tongues have impaired it (Virginia) much," Bullock declared in r649, "for it hath been a constant report among the ordinary sort of people that all those servants who are sent to Virginia are sold into slavery, whereas the truth is that the merchants who send servants and have no plantations of their own doe not only transferre their time over to others, but the servants serve no longer than the time they themselves agreed for in England, and this is the ordinary course in England, and no prejudice or hurt to the servant.", 
The terms of indenture not only took for granted that the servant, upon completing his contract, would establish himself as a proprietor, but usually made it obligatory for the master to furnish him with the equipment necessary for his new life. With rare exceptions he received a quantity of grain sufficient to maintain him for one year; two suits, one of Kersey, the other of cotton; a pair of canvas drawers; two shirts; and one felt hat. ${ }^{3}$ The historian Beverley states that to this outfit was added a gun worth twenty shillings." Another writer tells us that the freedman received "a year's provision of corne, double apparel" and a supply of tools. ${ }^{5}$

There existed in England a widespread impression that the servant, upon securing his freedom, was entitled by law to Ififty acres of land. This appears to have been a mistake arising from a misapprehension of the nature of the headright, which belonged not to the servant himself, but to the person who paid for his transportation. In many cases the indentures do not state the exact rewards to be received by the new freedman, but only that they are to accord with "the custom of the country," a very elastic term which could be construed by the master to suit his own interest. ${ }^{6}$ John Hammond, in his Leah and Rachel, strongly advised the immigrant before affixing his signature to the indenture to insist upon the inclusion of a clause specifically providing for the payment of the fifty acres. ${ }^{7}$ But the importance which attaches to this matter lies as much in the servant's expectation as in its fulfilment. Whether or not he received his little plantation, he believed that he was to get a tract of land, a very extensive tract it must have seemed to him, which would assure him a good living and make it possible for him to rise out of the class to which he belonged. ${ }^{8}$

In 1627 the Virginia General Court issued an order which is significant of the attitude of the colony itself to the freedmen. "The Court, taking into consideration that the next en- 
sueing year there will be many tenants and servants freed unto whom after their freedom there will be no land due, whereby they may without some order taken to the contrary settle and seat themselves... have ordered that the Governor and Council may give unto the said servants and tenants leases for terms of years such quantities of land as shall be needful.", Thus, at this period at least, not only was it expected in the colony that servants would become land holders, but it was felt that for them not to do so was a matter of such grave concern as to require the special attention of the Government.

After all, however, the key to the situation must be sought in the history of tobacco culture and the tobacco trade. Tobacco was the universal crop of the colony and upon it every man depended for his advancement and prosperity. If the market was good and the price high, the planters flourished; if sales fell off and the price was low, they suffered accordingly. It is evident, then, that the ability of the freedman to secure a position of economic independence hinged upon the profit to be derived from his little tobacco crop. It does not matter whether he worked as a wage earner, tenant or freeholder, in the end the result would be the same. If the returns from his labor greatly exceeded his expenses, his savings would make it possible for him to establish himself firmly in the class of the colonial yeomanry. On the other hand, if he conld wring fron the soil no more than a bare subsistence, he would remain always a poor laborer, or perhaps be forced to seek his fortume in some other colony. Thus if we are to understand the status of the freed servant and the hope which he could entertain of advancement, it is necessary to turn our attention once more to economic conditions in the colony. First, we must determine the amount of tobacco the, freedman could produce by his unassisted labor: second, the price he received for it; third, how much he had to give the 
merchants in exchange for their wares; and finally, the margin of profit left after all expenses had been paid.

Despite a marked divergence of testimony regarding the amount of tobacco one man could cultivate, we are able to determine this matter with some degree of exactness. In I627 the King, in outlining a plan to take into his own hands the entire tobacco trade, proposed to limit the imports to 200 pounds for each master of a family and 125 for each servant. ${ }^{10}$ To this, however, the planters entered a vigorous protest, claiming that the quantity was "not sufficient for their maintenance." They in turn suggested that the King take a total of 500,000 pounds a year, which for a population of 3,000 meant 167 pounds for each inhabitant, or perhaps about 500 pounds for each actual laborer. ${ }^{11}$ Again in 1634 it was proposed that the Crown purchase yearly 600,000 pounds of Virginia tobacco. ${ }^{12}$ As the population of the colony at that date was about 5,000 , this would have allowed only $\mathrm{I} 20$ pounds for each person, and once more the planters protested vigorously. ${ }^{13}$ It would seem that both of these offers were based not so much upon the amount that one man could raise as upon the quantity which could be sold in England at a certain price. In fact it is probable that even so early as 1628 the average output of one freedman was not less than 1,000 pounds. It is interesting to note that in $\mathrm{I} 640$, soon after Governor Francis Wyatt's arrival from England, it was found that the excessive crop of the previous year had so clogged the market that upon the advice of the merchants the Government was "forced to a strict way of destroying the bad and halfe the goode."

The author of $A$ New Description of Virginia, published in I649, claims that one man could plant from I,600 to 2,000 pounds a year. ${ }^{15}$ As the pamphlet presents a somewhat optimistic picture of affairs in general in the colony, this estimate 
must be taken with some reserve. More trustworthy is the statement of Secretary Thomas Ludwell in 1667 that $I, 200$ pounds was "the medium of men's yearly crops." 16

At all events, it is evident that the planter, even when entirely dependent upon his own exertions, could produce a goodly crop. It is now necessary to ascertain what he got for it. In the second and third decades of the Seventeenth century the price of tobacco was very high. The first cargo, consisting of 20,000 pounds consigned in the George, sold for no less than $£_{5,250}$, or $5 \mathrm{~s}$. $3 \mathrm{~d}$. a pound. ${ }^{17}$ No wonder the leaders of the London Company were pleased, believing that in the Indian weed they had discovered a veritable gold mine! No wonder the settlers deserted their pallisades and their villages to seek out the richest soil and the spots best suited for tobacco culture! The man who could produce 200 pounds of the plant, after all freight charges had been met, could clear some $£_{30}$ or $£_{35}$, a very tidy sum indeed for those days. It was the discovery that Virginia could produce tobacco of excellent quality that accounts for the heavy migration in the years from I 6 I 8 to I623. In fact, so rich were the returns that certain persons came to the colony, not with the intention of making it their permanent residence, but of enriching themselves "by a cropp of Tobacco," and then returning to England to enjoy the proceeds. ${ }^{18}$

But this state of affairs was of necessity temporary. Very soon the increasing size of the annual crop began to tell upon the price, and in I623 Sir Nathaniel Rich declared that he had bought large quantities of tobacco at two shillings a pound. ${ }^{19}$ This gentleman felt that it would be just to the planters were they to receive two shillings and four pence for the best varieties, and sixteen pence for the "second sort." In the same year Governor Wyatt and his Council, in a letter to the Virginia Company, placed the valuation of tobacco at 
eighteen pence a pound. ${ }^{20}$ Three years later, however, the Governor wrote the Privy Council advising the establishment in Virginia of a "magazine" or entrepot, where the merchants should be compelled to take the tobacco at three shillings a pound. ${ }^{21}$ This proposal did not seem reasonable to the King, and when Sir George Yeardley came over as Governor for the second time he was instructed to see to it that "the merchant be not constrained to take tobacco at 3. P. Pound in exchange for his wares," and to permit him to "make his own bargain." 22

Apparently not discouraged by this rebuff, in 1628 the Governor, Council and Burgesses petitioned the King, who once more was planning to take the trade into his own hands, to grant them "for their tobacco delivered in the colony three shillings and six pence per pound, and in England four shillings." ${ }^{23}$ This valuation undoubtedly was far in advance of the current prices, and King Charles, considering it unreasonable would not come to terms with the planters. In fact, it appears that for some years the price of tobacco had been declining rapidly. In May, I630, Sir John Harvey wrote the Privy Council that the merchants had bought the last crop with their commodities at less than a penny per pound, ${ }^{24}$ and two years later, in a statement sent the Virginia Commissioners, he claimed that the price still remained at that figure. ${ }^{25}$

It may be taken for granted, however, that this estimate was far below the actual price. The planters showed a decided tendency to blow hot or cold according to the purpose in view, and in these two particular statements Sir John was pleading for better treatment from the merchants. Yet it is reasonably certain that tobacco was at a low ebb in the years from 1629 to 1633 , and sold at a small fraction of the figures of the preceding decade. ${ }^{26}$ The Governor repeatedly wrote asking for relief, while in the Assembly attempts were made 
to restore the market by restricting the size of the annual crop. $^{27}$

Yet things must have taken a favorable turn soon after, for in 1634 the planters informed the King's Commissioners that they would not sell him their tobacco at less than six pence in Virginia and fourteen pence delivered in England. ${ }^{28}$ Later the King wrote to the Governor and Council that the rate had recently "doubly or trebly advanced." 29 This is substantiated by the fact that the Commissioners, in 1638 , allowed the planters " $4 \mathrm{~d}$. a pound clear of all charges," despite which they complained that in an open market they could do better. ${ }^{30}$

In 1638 several prominent Virginians estimated that on an average during the preceding eleven years they had received not more than two pence for their tobacco, but here again it is probable that there was some exaggeration. ${ }^{31}$ In 1649 the atthor of $A N e w$ Description of Virginia stated that tobacco sold in Virginia for three pence a pound. ${ }^{32}$ All in all it seems that prices in the early years of the settlement varied from five shillings to a few pence, that a disastrous slump occurred at the end of the third decade, followed by a rapid recovery which brought the rate to about three pence, at which figure it remained fairly constant for twenty-five years or more throughout the Civil War and most of the Commonwealth periods.

The return which the Virginia farmer received from his one staple crop was determined by a number of factors over which he himself had but little control. Had he been permitted to seek his own market and drive his own bargain free from the restraining hand of the British Government, no doubt he would have secured a much better price. But from the moment it became apparent that the Virginia tobacco rivalled in flavor that of the Spanish colonies and could command as ready a sale throughout Europe, the trade was sub- 
jected to various regulations and restrictions which proved most vexatious to the colony and elicited frequent and vigorous protests. Neither James nor Charles had any idea of permitting free trade. In their prolonged struggle with the liberal party both saw in tobacco a ready means of aiding the Exchequer, and so of advancing toward the goal of financial independence. These monarchs were by no means hostile to Virginia. In fact, both took great interest in the tiny settlement upon the James, which they looked upon as the beginning of the future British colonial empire. Yet they lent too willing an ear to those who argued that tobacco might be made to yield a goodly revenue to the Crown without injury to the planters.

The policy adopted by the early Stuart kings and adhered to with but minor changes throughout the colonial period consisted of four essential features. First, the tobacco raised in the plantations should be sent only to England; second, upon entering the mother country it must pay a duty to the Crown; third, Spanish tobacco should be excluded or its importation strictly limited; lastly, the cultivation of the plant in England itself was forbidden.

In the years when the colony was still weak and dependent upon the mother country this program was not unfair. The prohibition of tobacco growing in England, however unnecessary it would have been under conditions of free trade, was felt by the planters to be a real concession, while the restrictions upon foreign importations saved them from dangerous competition at the very time when they were least able to combat it. Nor were they seriously injured by the imposition of the customs duties. The planters themselves imagined that the incidence of this tax fell upon their own shoulders and that they were impoverished to the full extent of the revenues derived from it. But in this they were mistaken. The duty, in 
the last resort, was paid not by the planters but by the British consumers. The colonists were affected adversely only in so far as the enlianced price of tobacco in England restricted the market.

On the other hand, the prohibition of foreign trade was a very real grievance and elicited frequent protests from the planters. Dutch merchants paid high prices for the Virginia tobacco and offered their manufactured goods in return at figures far below those of the British traders. The Virginians could not understand why they should not take advantage of this opportunity. "I humbly desire to be informed from your honors," wrote Governor Harvey to the Virginia Commissioners in 1632 , "whether there be any obstacle why we may not have the same freedome of his Majesties other subjects to seek our best market." 33

But Harvey was attacking what already had become a fixed policy of the Crown, a policy which was to remain the cornerstone of the British colonial system for centuries. The Govermment had, therefore, not the slightest intention of yielding, and from time to time issued strict orders that all colonial tobacco, whether of Virginia or the IVest Indies, be brought only to England or to English colonies. When Sir William Berkeley was appointed Governor in 1642 he was instructed to "bee verry careful that no ships or other vessels whatsoever depart from thence, freighted with tobacco or other commodities which that country shall afford, before bond with sufficient securities be taken to his Majesty's use, to bring the same directly into his Majesty's Dominions and not elsewhere." ${ }_{34}$

Despite the insistence of the British Government in this matter, there is abundant evidence to show that the Virginians continued to indulge in direct trade with the continent for many years after the overthrow of the Company. In $163_{2}$ Governor Harvey wrote that "our intrudinge neighbours, the 
Dutch, doe allow us eighteen peance p. pound" for tobacco, while a few months later we find him reporting the attempt of John Constable and others "to defraud his Majesty of his duties by unloading in the Netherlands." 35

With the advent of the English Civil War and throughout the Commonwealth period Virginia enjoyed a large degree of independence and found it possible to trade with the Dutch almost with impunity. Even the strict Berkeley seems to have felt it no disloyalty for the planters to seek foreign markets for their staple while the mother country was torn by the contending armies of King and Parliament. And so the merchantmen of Flushing and Amsterdam pushed their prows into every river and creek in Virginia and Maryland, taking off large quantities of tobacco and giving in return the celebrated manufactured goods of their own country. At Christmas I648, if we may believe the testimony of the author of $A$ New Description of Virginia, there were trading in the colony ten ships from London, two from Bristol, seven from New England and twelve from Holland. In I 655 the statement was made that "there was usually found intruding upon the plantation divers ships, surruptitiously carrying away the growth thereof to foreign ports to the prejudice of this Commonwealth., ${ }^{36}$

Thus in the years prior to the Restoration Virginia was never fully subjected to the operation of the British colonial system. When the price of tobacco in the London market fell lower and lower, the planters might and often did find relief by defying the King's commands and trading directly with the Dutch. ${ }^{37}$ And this benefitted them doubly, for not only did they strike a better bargain with the foreign traders, but every cargo of tobacco diverted from England tended to relieve the market there and restore prices. In fact there can be little doubt that the frequent violations of the trade re- 
strictions of this period alone saved the colony from the poverty and distress of later days and made possible the prosperity enjoyed by the planters.

It must be noted also that of the tobacco sent to England itself, a part was reshipped to foreign countries. In I6ro a law was enacted for the refunding of all import duties upon articles that were re-exported. This drawback applied also to colonial products, but under Charles I an exception was made in their case and the privilege withdrawn. In consequence the importers made a vigorous protest in Parliament, and the King, in $163 \mathrm{I}$, modified his policy by ordering that of the nine pence duty then in operation, six pence should be refunded when the tobacco was shipped abroad. In 1632 the drawback was increased to seven pence leaving the total duty paid by the merchants who traded through England to foreign countries two pence a pound only. ${ }^{38}$ Although this constituted a most serious obstacle to trade and at times aroused the merchants to bitter protest, it by no means completely blocked re-exportation. So great were the natural qualifications of Virginia for producing tobacco, that it was possible to purchase a cargo from the planters on the James, proceed with it to London, pay there the two pence a pound duty, reship it to the continent and sell it there at a profit. ${ }^{39}$ Although this trade was not extensive, it must have had an important influence in maintaining prices and in bringing prosperity to all classes in the colony.

Thus Virginia, contrary to the wishes of the mother country and in defiance of her regulations, enjoyed for its staple product in the years prior to I660, a world market. Whether by direct trade or by re-exportation from England a goodly share of the annual crop was consumed in foreign countries, a share which had it been left in England to clog the market, would have reacted disastrously upon all concerned. 
It is apparent, then, that in the first half century of its existence Virginia was the land of opportunity. The poor man who came to her shores, whether under terms of indenture or as a freeman, found it quite possible to establish himself as a person of some property and consideration. We may imagine the case of the servant who had completed his term and secured his freedom at any time during the third decade of the Seventeenth century. As we have seen, it was an easy matter for him to secure a small patch of land and the tools with which to cultivate it. By his unassisted efforts, if he applied himself steadily to the task, he could produce a good crop of tobacco, consisting perhaps of some 400 pounds. This he could sell to the merchants for from two shillings to six pence a pound, or a total of from $\mathfrak{E}_{\text {IO }}$ to $\mathfrak{E}_{40}$. $^{40}$

In the years from I 630 to 1640 , when the price of tobacco seems to have stabilized itself at from two to three pence, cases of such extraordinary returns must have been of less frequent occurrence, but to some extent lower prices were offset by larger crops. If our freedman in I635 could raise 800 pounds of leaf and dispose of it for four pence, his income would be $\mathfrak{E}_{\mathrm{I}} 3.6 .8$; in I649, by producing $\mathrm{I}, \mathrm{O0O}$ pounds, he could sell it at three pence for $\mathfrak{f}_{12}$.10.o. In fact, it is not too much to say that the average annual income from the labor of one able worker at any time prior to 1660 was not less than $\mathfrak{f}_{12}$. When we take into consideration the fact that the planter produced his own food, and that out of the proceeds of his tobacco crop he paid only his taxes and his bills to the English importers, it is evident that he had a goodly margin of profit to lay aside as working capital.

It must not be forgotten, however, that this margin was greatly reduced by the high cost of clothing, farm implements and all other articles brought from across the ocean. The long and dangerous voyage from London to the Chesapeake 
made the freight rates excessive, while the merchants did not scruple to drive a hard bargain whenever possible. The letters of the Governors are filled with complaints against the exactions of these men. "This year the Merchants have bought our tobacco with their commodities at less than a penny the pounde," Harvey wrote in 1630 , "and have not shamed to make the planters pay twelve pounds Sterlinge the tunn freight home." ${ }^{41}$ Two years later he complained that a certain Captain Tucker had just sailed leaving his stores well stocked with goods, but with "instructions to his factors not to sell but at most excessive rates." ${ }^{42}$ In 1628 , the Governor, Council and Burgesses, in a petition to the King, declared that for years they had "groaned under the oppression of unconscionable and cruel merchants by the excessive rates of their commodities." ${ }^{\prime 3}$ Six years later Governor Harvey stated that all things which "come hither" are sold at "thrice the value they cost in England.",44

It is obvious, however, that after all expenses had been paid, a goodly margin of profit was left, a margin perhaps averaging some three or four pounds sterling. The provident and industrious immigrant, a few years after the conclusion of his term, might well lay aside enough to make it possible for him in turn to secure a servant from England. This accomplished, he at once rose into the class of employers and his future advance was limited only by his capabilities and his ambition.

We would naturally expect to find, then, that during these years a large percentage of those who came to the colony under terms of indenture, sooner or later acquired land, perhaps bought servants, and became persons of some standing in the colony. Certainly the opportmity was theirs. It will be interesting therefore to study the early records in order to glean what evidence we may concerning this matter. If the servants graduated in any appreciable numbers into the planter 
class, the patents, wills, inventories, land transfers and muster rolls could hardly fail to yield some evidence of the fact.

Turning first to the earliest period, we find that of the laborers who were imported by the London Company to cultivate the public lands, a fair proportion became proprietors and were regarded by later comers with especial esteem as "ancient planters." At the termination of their service they were granted Ioo acres and when this was fully cultivated received another tract of the same extent. To the apprentices bound out to tenants even more liberal treatment was accorded, for they were provided with a year's store of corn, a house, a cow, clothing, armor, household utensils, farm tools and as much land as they could till. ${ }^{45}$

The guiding hand of the Company was missed by the freedmen after the revoking of the charter, for the Governors seem to have left them to shift for themselves. Yet this fact did not prevent many from forging ahead, acquiring land, and in some cases positions of trust in the Government itself. In Hotten's Immigrants is published a muster roll for the year 1624 of all the settlers in Virginia, in which servants are carefully distinguished from freemen. ${ }^{46}$ By following, as well as the imperfect records of the period permit, the after careers of the former, it is possible to determine with a fair degree of accuracy to what extent the small farmer class at this period was recruited from persons coming to the colony under terms of indenture.

Of the forty-four Burgesses who sat in the Assembly of I629, no less than seven-John Harris, William Allen, William Popleton, Anthony Pagett, Richard Townsend, Adam Thoroughgood and Lionell Rowlston-were listed as servants in the muster of $1624 .^{47}$ Thus some sixteen per cent of this important body, the Virginia House of Commons, at this time was made up of men who five years previously had been work- 
ing out their passage money. Among the thirty-nine members of the House of 1632 , six appear as servants in the musterThomas Barnett, Adam Thoroughgood, Lionell Rowlston, Thomas Crump, Roger IVebster and Robert Scotchmon. Whether there were other members who came over under terms of indenture but secured their freedom before 1624 , we have no means of determining.

The author of I'irginia's Curc, published in I662, asserted that the Burgesses "were usual such as went over as servants thither; and though by time, and industry, they may have obtained competent estates, yet by reason of their poor and mean condition, were unskilful in judging of a good estate, either of church or Commonwealth." 48 This statement is a gross exaggeration both as to the composition of the Burgesses and their abilities. Instances of the election of freedmen to the House, fairly frequent in the early years of the colony, became rarer as the century advanced and the field of selection widened. Yet in the Assembly of I652, of the thirty-five members, eight or nine appear on the patent rolls as headrights brought over by others. ${ }^{49}$ It is evident that even so late as the middle of the century the door of opportunity was still open to the freedmen.

In the absence of a complete census for the decades after I624, it is very difficult to determine what proportion of the servants listed in the muster roll of that year subsequently became landowners. Some light is thrown on the matter by a search through the patent books. Here are found a surprisingly large number of persons who in $\mathrm{I} 624$ were servants. Among these are Anthony Jones, John Sparkes, John Cooke, Roger Delk, John Trussell, William Woolritch, Pettyplace Cloyse, Edward Sparshott, IVilliam Dawson, Richard Bell, Robert Browne, Nicholas Browne, John Chandler, Lionell Rowlston, Thomas Savadge, Samuel Bennett, Daniel Shurley, 
James Hatfield, Adam Thoroughgood, John Robinson, John Hill, John Seaward, William Ramshaw, Samuel Weaver, John Upton, John Watson, Thomas Crompe and John Russell. ${ }^{50}$

Of these persons several acquired a fair degree of wealth and became of importance in the early life of the colony. It is interesting to note also, that some were men of good condition in England, the case of Adam Thoroughgood, whose brother Sir John Thoroughgood was at one time secretary to the Earl of Pembroke, is notable in this respect. John Hill, before coming to Virginia, had been a book binder in Oxford university, and his father had been a fletcher. ${ }^{51}$ The patents of Thomas Crompe and John Russell state that fifty acres was due in each case for the "personal adventure" of the patentee, but since they are distinctly listed as servants in 1624 it seems probable that subsequently each made a visit to England and put in claims for the headright for the return voyage. ${ }^{52}$

Thus it is evident that a large proportion of the landholders during and prior to 1635 had come to the colony under terms of indenture, either under the Company or with private individuals. Perhaps it would not be unfair to estimate this proportion at from thirty to forty per cent, but it must be distinctly understood that the matter cannot be determined with any degree of accuracy or finality. Some years later Governor Berkeley in an address before the Assembly, stated that hundreds of examples testified to the fact that no man in Virginia was denied the opportunity to rise and to acquire both property and honor. ${ }^{53}$ Careful research tends to corroborate this assertion but it does not and cannot show whether the bulk of the early planters came to the colony as freemen or as indentured servants.

During the years from 1635 to I 660 the process of building up a class of small farmers in large part from freedmen continued unabated. But the difficulties of the investigator in 
studying this period are also very great. Yet it is possible, by examining the names that appear in the land patents and wills, and comparing them with the list of healrights, to arrive at fairly satisfactory results. IVe fund that of the I 3 i persons listed in the lork county wills from 1646 to 1659 no less than wenty-five appear as healrights for others. Of these the major part became landowners, some of them men of influence in Virginia." The Rappalannock wills for the years from 1656 to 1664 show a like result. Thirty-nine persons appear in the records, of whon seven came in as headrights. ${ }^{55}$

There is always the possibility of error in identifying these persons for the recurrence of such names as Sulth, Jones, Turner, Davis, Hall, the monotonous repetition of a few common given names, and the miversal omission of middle names ack greatly to our difficulties. Moreover, mistakes are apt to occur hecause of the transfer of heallights by sale. The free immigrant to whom was due fifty acres for his "personal atventure" might not care to settle on the frontier where alone mpatented land could usually be found. At times he sold his right and purchased a plantation in some one of the chler and more alvancel comties. It is not conclusively proved, then, that a certain person came as a servant merely hecause he is listed as a headright. On the other hand, the fact that it was the custom to set forth such transfers clearly in the patent itself, justifies the conclusion that in the cases where no statement of the kind is made, the hearlright for which the land was granted usually came in under terms of indenture.

In Volume III of the land patents are listed in the years from 16.35 to 165.3 patents to fifty-seven persons in James City comnty. ${ }^{56}$ Of these no less than thirty-one are found also as headrights belonging to others, although a duplication of names in several cases makes identification uncertain. One 
person only claimed the fifty acres for having paid his own passage to Virginia. When all possible allowance is made for transfers of rights it is obvious that at this time freedmen were still entering freely into the class of landowners.

An examination of the James City county patents in Volume IV, covering the years from $1 \sigma_{5.3}$ to $16 \sigma_{3}$, learls to similar results, for of the eighty-five names which appear there, forty-five are listed as hearlights belonging to others. And although the tracts granted these men were usually small in size, in certain cases they were far in excess of the average plantation. Thus Edward Cole, who appears as a headright in 1642 , patented 900 acres in $1655, ; 7$ Thomas Warburton patented $\mathrm{I}, 654$ acres $;^{58}$ (jeorge Gillert 1,000 acres; Francis Burwell r,OOO and John Underwood 2,000 acres. ${ }^{50}$ The number of years which elapsed between the listing of the headrights and the granting of the patents varied from two to twentyeight. The average for the thirty-five cases in which the dates are given is twelve years. $\Lambda$ s the claims for hearlrights were often marle long after the actual arrival of the servant, it may be assumed that the average was even greater than this. Once more, however, it must be remembered that these lists lo not record personal transfers of land, while it is quite certain that many freerlmen, instearl of patenting unoccupied tracts, secured their little farms by purchase. Some probably became proprietors in the very first year of their freerlom and set to work with hoe and plow to wrest their living from the soil.

In the patent rolls the bulk of the headrights are alluded to simply as "pcrsons," leaving it undecided whether those included in the various lists are freemen or servants. But occasionally the newcomers are specifically described as "servants," in which case, of course, there can be no doubt whatever as to their status. By selecting at random a number of names from those so termerl, avoiding for convenience sake 
all Smiths, Joneses and others the frequent recurrence of whose names would make identification difficult, it is possible to arrive at definite conclusions by following, as best we can, their careers in after life. IVith this in view we have made up the following list of servants: Henry Arnetrading, George Archer, Silvester Atkins, Nicholas Atwell, Edward Ames, John Aram, Robert Arnall, Peter Asheley, William Baldwin, Edward Burt, Francis Baile, John Bauchees, John Bishop, John Blackstone, Anthony Box, Michael Brichley, Peter Buck, William Burcher, John Causey, Robert Chesheire, Thomas Chilcott, Thomas Clayton, Annanias Coplestone, James Courtney, Thomas Cropp, Thomas Connagrave, John Day, John Dodman, Jonathan Ellison, Edward Eastwood, James. Fletcher, Thomas Foanes, John Fouke, Francis Francklin, Armstrong Foster, Robert Fossett, John Farr, Robert Garsell, George Gilbert, Henry Giles, Hector Godbear, Francis Gray, Reginald Griffin, Thomas Halcock, Thomas Hand, Henry Hartwell, Hugh Hayes, John Hedler, Richard Huett, John Hodgbins, John Holdin, William Hankinson, John Hether, Lazarus Manning, Thomas Pattison, John Pullapin, Sampson Robins, George Walton, Francis Withers, Robert Webstie and Thomas Warden. A search through the patent rolls, wills, tithable lists and other data found in the records of the period, has led to the more or less positive identification of fifteen of these persons.

John Bishop, who was transported by Thomas Gray, became a man of influence and means. He represented Charles City county in the House of Burgesses in the sessions of I644, I 652 and I653, and was variously known as Captain Bishop or Mr. Bishop. ${ }^{60}$ Although he became a landowner so early as $1638,{ }^{61}$ his family arrived from England only in I65I. Francis Gray, brought to Virginia at the age of fifteen by Joseph Johnson, also became prominent, securing a 
seat in the Assembly and acquiring a fair estate. In 1653 he took up $75^{\circ}$ acres in Charles City county, while ten years later he is credited with 374 acres more in Westmoreland. ${ }^{62}$ His will was recorded in $1667 .{ }^{63}$

George Archer became an extensive landowner, patenting 250 acres in $1663,55^{\circ}$ acres in 1665,784 acres in $167 \mathrm{I}$ and $\mathrm{I}, 395$ acres in $1673 .{ }^{64}$ In $\mathrm{I} 69 \mathrm{I}$ he received, in conjunction with others, title to a tract of 2,827 acres in Henrico. ${ }^{65}$ John Holding patented in York county 850 acres in 1649 and 389 acres in $1653 .{ }^{66}$ William Baldwin, who came in the Plaine Joan when he was twenty-four years of age, received three grants of land, one for 600 acres in York county, one for 67 acres in Isle of Wight, and one, in conjunction with Richard Lawrence, for 300 in Rappahannock. ${ }^{67}$

Thomas Pattison, transported by Francis Epes in 1635 , took up in Lancaster two tracts, one for 200 acres and one for $400 .^{68} \mathrm{He}$ also became part owner of two more tracts, one for 220 acres and the other for $504 .^{69}$ John Dodman secured a patent for $35^{\circ}$ acres in Westmoreland in the year I662. ${ }^{70}$ Thomas Warden is mentioned as a landowner in James City county in $1643 .{ }^{71}$ George Gilbert, transported in I 635 by Joseph Johnson, took up fifty acres in James City county in $1643 .^{72}$ In 1663 , in partnership with Richard Scruely, he patented 1,000 acres in the same county north of the Chickahominy river. ${ }^{73}$ John Blackstone acquired two tracts, one for 100 acres and the other for $15 \mathrm{I}$ acres, ${ }^{74}$ while William Burcher received a grant for 300 acres. ${ }^{75}$

Several of these men who came as servants to the Eastern Shore are found in succeeding years among the yeomanry of Accomac and Northampton. Henry Arnetrading, Armstrong Foster, William Burcher and Sampson Robins were signers of the Northampton submission to the Commonwealth in $165^{2 .}{ }^{76}$ Henry Arnetrading was the owner of 300 acres of land. ${ }^{77}$ 
Armstrong Foster was the official tobacco viewer for Hungers, a position entailing no little responsibility. ${ }^{78}$ Sampson Robins received a patent for a tract of land in Northampton in $1655 .^{79}$ Thomas Clayton is listed among the Northampton tithables of $1666 .{ }^{80}$

In the case of John Day some uncertainty arises. Apparently there were two men of this name in the colony, one transported by John Slaughter, and the other not only paying for his own passage, but for that of a servant as well. ${ }^{81}$ A John Day later secured 400 acres in Gloucester county, ${ }^{82}$ but whether it was the one who had come as a servant or the one who had entered the colony as a freeman, apparently there is no way of ascertaining.

All in all the story of these men tends to confirm the conclusions hitherto arrived at. It must be remembered that the mortality among the servants in the tobacco fields in the early clays of the colony was extremely heavy. It is not improbable that of our sixty-one servants, twenty or more succumbed before the completion of their first year. That of the remaining fortyone, fourteen or fifteen established themselves as solid farmers, while several became men of influence in the colony, is a striking proof that at this period many freedmen had the opportunity to advance. Taking it for granted that the records of some of the sixty-one have been lost, or that our research has failed to reveal them, we once more come to the conclusion that a full thirty or forty per cent of the landowners of the period from I635 to I666 came to the colony under terms of indenture.

On the other hand, it is equally positive that the class of poor planters was recruited in part from free immigrants, men who paid their own passage across the ocean and at once established themselves as freeholders. Of this too, the records furnish ample testimony. Thus in 1636 we find that 
Richard Young was granted Ioo acres in Warwick "due him for his personal adventure and for the transportation of his wife Dorothy Young." $\$$ A year later Roger Symonds received Ioo acres in Charles City "due him for the transportation of his wife, Alice, and one servant, Richard Key." ${ }^{4}$ Similarly in May I6 36 , Thomas Wray was allowed 50 acres for his "personal adventure." Such cases could be multiplied indefinitely. ${ }^{85}$

A careful analysis of the patent rolls from i 623 to July I 4, I637, published in the Virginia Magazine of History and Biography for April, I9OI, shows conclusively that the lists contain the names of many persons who at no time were under terms of indenture. Of the 2,675 names appearing in the records, the editor states that 336 are positively known to have come over as freemen, many of them being heads of families. "There are 245 persons whose names do not occur as headrights and yet of whom it is not positively shown that they were freemen, though the probability seems to be that by far the greater number were. And there were 2,094 persons whose transportation charges were paid by others. This last number includes some negroes, all those specifically termed 'servants' and all others. . . It would probably be a fair estimate to say that of the names represented in the patents cited, there were about 675 free men, women and children who came to Virginia and about 2000 servants and slaves." ${ }^{\prime 86}$ Similarly in the issue of the magazine for January, I902, the editor says that "for some years, about this period, it is probable (from the best calculations which can be made) that seventy-five per cent of the emigrants to Virginia were indentured servants." ${ }^{87}$

There seems to be no reason to doubt the accuracy of these conclusions. Certainly any study of immigration to Virginia in the Seventeenth century is woefully incomplete if it fails to take into consideration the very considerable proportion of 
iree settlers. On the other hand, it is probable that a similar study of the lists for a later date would show a smaller percentage of ireemen. However this may be, it is evident that by far the larger part of the newcomers at all periods must have been indentured servants intended for service in the tobacco fields. In $16_{3} \&$ Richard Kemp wrote Secretary Windebanke that "oi hundreds which are yearly transported, scarce any but are brought in as merchandise to make sale of." "ss

let it must not be forgotten that any immigration of poor treemen, however small, would have a very marked influence upon the formation of the small iarmer class. Oi the host of servants a certain proportion only, a proportion probably less than fitty per cent, could hope even in the most favorable times to become ireeholders. If they survived the hardships and dangers of the service with their masters, it still remained for them to acquire property and win for themselves a place in the life of the colony. And to accomplish this they must display determination, intelligence. industry and thrift, qualities by no means universal among the classes in England from which the servants were chiefly drawn. But for the free immigrant there need be no period of probation. He might at once purchase his farm, erect his home, secure all necessary tools and put out his crop of tobacco. And whereas the servant usually found it possible to maintain a family only after many years of hard work, perhaps not at all, the free settler often married before leaving England and brought his wife and children with him.

In conclusion it may be said that in the first fifty years of the colony's existence conditions were very favorable for the graduation of the servant into the class of small ireeholders, that the records amply prove that many succeeded in doing so, but that at this period a fair proportion of free immigrants also came to the colony. Before the expiration of the Com- 
monwealth period was formed from these two sources, perhaps in not unequal proportions, a vigorous, intelligent, independent yeomanry, comprising fully 90 percent of all the landowners. 


\section{CHAPTER $V$}

\section{The Restoration Period}

ThE people of Virginia hailed the Restoration with unaffected joy. Not only did they anticipate that the termination of the long period of civil war and unrest in England would react favorably upon their own prosperity, but they felt that Sir William Berkeley's well known loyalty and his action in proclaiming Charles II immediately after the execution of his father, might assure them the King's especial favor now that he at last had come into undisputed possession of his throne. They were doomed to bitter disappointment, however, for the Restoration brought them only hardship and suffering, discontent and rebellion.

No sooner had the royal Government been safely installed than it set to work to perfect and to enforce the colonial policy which in principle had been accepted from the first. The ties which united the colonies with the mother country were strengthened, those which gave them a common interest with foreign nations in so far as possible were snapped. The British empire was to become a unit, closely knit by economic bonds and presenting to all other nations a hostile front. With this in view Parliament passed a series of Navigation Acts, under which the trade of the colonies was regulated for many years to come.

It is necessary for us to enquire, therefore, into the effects of these laws upon the tobacco trade, for tobacco, as we have seen, was the key to the prosperity of the colony, and favorable economic conditions alone could make it possible for the newcomer to establish himself as a member of the Virginia 
yeomanry. If the strict enforcement of the Navigation Acts should bring low prices for tobacco and wipe out the margin of profit for the man who tilled the soil with his own hands, not only would the small planter class not expand, but might actually decline in numbers.

There were three main features of the colonial legislation of Parliament during this period, all of them interrelated and all tending toward the one great object of keeping the English plantations for the English. It was provided that the chief colonial products such as tobacco and sugar should be sent only to England or to English colonies, that the colonies should with few exceptions import goods only from British territory, that all products taken to or from any colony should be conveyed only in English vessels manned by crews composed mainly of Englishmen.

In committing itself to this policy the royal Government felt that the plantations would play a useful and necessary part in the great system which was planned, and in so doing would find prosperity. It had been the hope of the English people that their colonies would produce the articles which were so badly needed by the mother country to revive her waning industry and permit a greater measure of economic independence. Although more than half a century had passed since the first foothold had been gained upon the American continent, this expectation was as far from realization as ever. The colonies, from Massachusetts to Barbados were producing, not the articles which England especially needed, but those for which they had the greatest natural aptitude, especially tobacco and sugar. And these staples they sent, not to England alone, but to various foreign countries as well.

In short the vision of a closely knit, self-sustaining empire, the vision which had been in men's minds for many decades before the founding of Jamestown, seemed to have proved 
delusive. The colonies were developing interests and commercial connections hostile to those of the mother country, were nourishing the manufactures and shipping of foreign nations almost as much as those of England. And this the Government at London would not tolerate. The colonial trade with strangers must come to an end. If Virginia and Maryland produced more tobacco than the English market could absorb, they could find ready relief by turning their energies into other channels. Let them furnish the old country with pig iron or potash or silk or ship-stores and they would find ready and eager purchasers. So reasoned the English, and as their views were backed by the mandates of Crown and Parliament, the colonists were forced to submit. If they could fit themselves into the system prescribed for them, all would be well and good; if they found this impossible, they would have to suffer without hope of redress.

And suffer Virginia did for a full quarter of a century. The tobacco of the Chesapeake bay colonies had long since reached the point where it required a world market. If confined to England alone, only a fraction of the output could be consumed and disaster was certain. It was well enough for the Government to restrict the importation of Spanish leaf and to prohibit the planting of tobacco in England, these regulations could do no more than give the colonists undisputed possession of the home market, and the home market was not enough. This point seems to have been ignored by those writers who have contended that the strict enforcement of the British colonial system in itself entailed no hardship upon the tobacco colonies.

"It is obvious that any criticism of England's regulation of the colonial tobacco trade, which is based on a laissez-faire social philosophy," says George Lewis Beer, in The Old Colonial System, "is equally applicable to the arrangement by 
means of which the tobacco planter secured exlusive privileges in the home market." ${ }^{1}$ Yet it is certain that the tobacco growers of England could never have competed with Maryland and Virginia had there been free trade. The prohibition of planting in the old country was necessary only because of the tariff, varying from 200 per cent in 1660 to 600 per cent in I705, upon the colonial product. And though the exclusion of Spanish tobacco was a more real benefit, for the Spaniard produced varieties unknown in Virginia, there is exaggeration here also. This is clearly shown by the fact that at the end of the Seventeenth century England was sending millions of pounds of her colonial tobacco to Spain itself. ${ }^{2}$ The leaf was brought from Virginia and Maryland, forced to pay a duty of about fifty per cent, and re-exported to the Spanish ports, where it found a ready sale. Had there been free exchange of commodities, the English colonies would have sold to Spain more tobacco than the Spanish colonies to England.

In truth the loss of the foreign market was a terrible disaster. In framing the Navigation Acts it was not the intention of the Government to stop entirely the flow of tobacco to the continent of Europe, but to divert it from the old channels and make it pass through England. It was therefore provided that in case the leaf was shipped out again to foreign ports, all the duties, except one half of the Old Subsidy, should be withdrawn. ${ }^{7}$ The remaining half penny, however, amounted to forty or fifty per cent of the original cost of the goods, and proved at first an almost insuperable barrier to the European trade. Moreover, the shortage of ships which resulted from the exclusion of the Dutch merchants, the expense of putting in at the English ports, the long and troublesome procedure of reshipping, all tended to discourage the merchants and hamper re-exportation.

We may take for granted also that the resentment of Hol- 
land at the Navigation Acts, which struck a telling blow at her maritime prestige, played an important part in blocking foreign trade. The Dutch had been the chief European distributors of the Virginia and Maryland tobacco, and if they refused to take it, now that it could be secured only in England, it would pile up uselessly in the London warehouses. They understood well enough that the half penny a pound duty was a tribute levied upon them by their most dangerous rival. It is not surprising that instead of bowing to the new restrictions, they sought to free their trade entirely from dependence on British tobacco, by fostering the cultivation of the plant in their own country.

The colonists found an able defender in the merchant John Bland. In a Remonstrance addressed to the King this man set forth with remarkable clearness the evils which would result from the Navigation Acts, and pleaded for their repeal. The Hollander was already beginning to plant tobacco, he said, and would soon be able to supply all his needs at home. "Will he, after accustomed to the tobacco of his own growth," he asked, "ever regard that which is in Virginia? Will he ever afterwards be induced to fetch it thence, when he finds his profit nigher at home? Will he ever buy that of us, when by passing so many hands, and so much charge contracted thereon, is made so dear, that he can have it cheaper in his own territories? (Surely no.) Therefore it clearly appears, that being so, of necessity we must lose that Trade and Commerce."

"If the Hollanders must not trade to Virginia, how shall the Planters dispose of their Tobacco? The English will not buy it, for what the Hollander carried thence was a sort of tobacco not desired by any other people, nor used by us in England but merely to transport for Holland. Will it not then perish on the Planters hands?... Can it be believed that 
from England more ships will be sent than are able to bring thence what tobacco England will spent? If they do bring more, must they not lose thereby both stock and Block, principle and charges? The tobacco will not vend in England, the Hollanders will not fetch it from England; what must become thereof? . . . Is not this a destruction to the commerce? For if men lose their Estates, certainly trade cannot be encreased."8

The enforcement of the trade laws was indirectly the cause of still another misfortune to the colonies, for the two wars with Holland which grew out of it reacted disastrously upon their trade. In fact, on each occasion the small stream of tobacco which had trickled over the dam of restrictions into foreign countries was for a time almost entirely cut off. Not only did the tobacco exports to Holland itself come to an end, but the Dutch war vessels played havoc with the trade between England and other countries and even between England and her colonies.

The loss of their foreign exports was calamitous to the planters. Had the demand for tobacco been more elastic, the consequences might not have been so fatal, for declining prices would have stimulated consumption and made it possible for England to absorb most of the output. But the duty kept up the price and the result was a ruinous glut in the English market. Tobacco sufficient for a continent poured into the kingdom, where since the normal outlet was blocked by the half penny a pound on re-exported leaf, it piled up uselessly.

The effect upon prices was immediate. The planters were forced to take for their crops half of what they had formerly received and had reason for rejoicing if they could dispose of it at all. In I 662 Governor Berkeley and other leading citizens stated that the price of tobacco had fallen so low that it would not "bear the charge of freight and customs, answer the adventure, give encouragement to the traders and sub- 
sistence to the inhabitants." ${ }^{\prime}$ In I666 Secretary Thomas Ludwell told Lord Arlington that tobacco was "worth nothing." ${ }^{0}$ Later in the same year the planters complained that the price was so low that they were not able to live by it." "For the merchants, knowing both our necessities and the unconsumable quantities of tobacco we had by us," they said, "gave us not the twentieth part of what they sold it for in England." 12 Tobacco had so glutted the markets, it was declared, and brought the planter so small a return, that he could "live but poorly upon it." In fact, the merchants in 1666 had left the greater part of the two preceding crops upon their hands. ${ }^{13}$

"Twelve hundred pounds of tobacco is the medium of men's crops," wrote Secretary Ludwell to Lord John Berkeley in I667, "and half a penny per pound is certainly the full medium of the price given for it, which is fifty shillings out of which when the taxes ... shall be deducted, is very little to a poor man who hath perhaps a wife and children to cloath and other necessities to buy. Truly so much too little that I can attribute it to nothing but the great mercy of God ... that keeps them from mutiny and confusion." ${ }^{14}$ The following year he wrote in similar vein. The market was glutted; a third of the planters' tobacco was left on their hands; the rest sold for nothing. ${ }^{15}$

The Governor and Council declared that the merchant "allows not much above a farthing a pound for that which the planter brings to his door. And if there shall be any amongst us who shall be able to ship his tobacco on his own account, it will be at such a rate as the tobacco will never repay him, since they are inforced to pay from $£_{I 2}$ to $£_{I} 7$ per ton freight, which usually was but at seven pounds." "16 "A large part of the people are so desperately poor," wrote Berkeley in I673, "that they may reasonably be expected upon any small ad- 
vantage of the enemy to revolt to them in hopes of bettering their condition by sharing the plunder of the colony with them." ${ }^{17}$ That matters had not changed in I68I is attested by the statement of the Council that the impossibility of disposing of their tobacco without a heavy loss overwhelmed both Virginia and Maryland, and brought upon them a "vast poverty and infinite necessity." "18 "The low price of tobacco staggers the imagination," Lord Culpeper wrote to Secretary Coventry, "and the continuance of it will be the speedy and fatal ruin of this noble Colony." 19

These distressing conditions bore with telling weight upon the small planters. The margin of profit which formerly had made it possible for the freedman to advance rapidly was now wiped out entirely and the poor man found it impossible to keep out of debt. In I668 Secretary Ludwell declared that no one could longer hope to better himself by planting tobacco. $^{20}$ Eight years later Nathaniel Bacon, in justifying his rebellion declared that the small farmers were deeply in debt and that it was "not in the power of labor or industry" to extricate them. ${ }^{21}$ "The poverty of Virginia is such," said a certain John Good in 1676 , "that the major part of the inhabitants can scarce supply their wants from hand to mouth, and many there are besides can hardly shift without supply one year." ${ }^{22}$ In 1673 the Governor and Council reported that of the planters, "at least one third are single persons (whose labor will hardly maintain them) or men much in debt," who might reasonably be expected to revolt to the Dutch upon any small advantage gained by them. ${ }^{23}$ In 1680 they again reported that "the indigency of the Inhabitants is such that they are in noe manner capacitated to support themselves." Three years later they wrote that "the people of Virginia are generally, some few excepted, extremely poor, not being able to provide against the pressing necessities of their families." ${ }^{25}$ 
Despite this repeated and explicit testimony of the misery and poverty of the colony during this period, which resulted from the stagnation of the tobacco market after the passage of the Navigation Acts, the surprising statement is made by Mr. George Lewis Beer, in The Old Colonial System, that England's trade restrictions had nothing to do with Bacon's Rebellion. "It has been at various times contended," he says, "that the uprising was, in part at least, one against the laws of trade and navigation. If there had existed in Virginia any widespread and well defined feeling of antagonism to these laws, it would unquestionably have found expression in the county grievances. Most of these reports were drawn up in a number of articles, and in all there were nearly two hundred of such separate subdivisions, yet only three of this number refer in any way to these statutes. There is no valid reason for assuming that the commercial system played any part whatsoever, or was in any degree, an issue, in the upheaval of I676.", 26

If by this statement it is meant that Bacon and his men did not rebel in order to force the repeal of the Navigation Acts, or even that they did not have the acts in mind at the time, there are many students of Virginia history who will agree with it. But if Mr. Beer means that these laws, with their baleful effect upon the prosperity of Virginia, did not produce the conditions fundamental to the rising, he is certainly wrong. The evidence is overwhelming.

Surely no one will deny that misery, poverty and nakedness are breeders of sedition. Had it not been for the Navigation Acts there would not have been so many desperate persons in Virginia ready at any excuse to fly in the face of the Government. Bacon's men were just the type of miserably poor freemen that Berkeley several years before had feared would rebel. He himself, in his proclamation of Feb. 10, 1677 , spoke of 
them as "men of mean and desperate fortunes.",27 William Sherwood called the rebels rude and indigent persons, alluding to them as "tag, rag and bobtayle." ${ }^{28}$ Over and over again they are described as the multitude, the rabble, the skum.

Exception must be taken also to the statement that had there existed in Virginia any well-defined feeling of antagonism to the Navigation Acts it would have found expression in the county grievances. It should be remembered that these reports had been called for by the commissioners sent over by Charles II to investigate the troubles. The men who drew them up occupied the position of defeated rebels, and the grievances were primarily a list of excuses for their treason. They all stood trembling for their property, if they had any, and for their miserable lives. The memory of the fate of Drummond and Bland and Arnold and many others of their fellow rebels was fresh in their minds. It is not reasonable to suppose that they would tell the King that they had risen in arms against his authority in order to secure the overthrow of laws which his Majesty considered of such vital importance, laws which concerned intimately the royal revenue. Such a declaration would not have seconded successfully their plea for mercy. This is made amply clear by the reception accorded one of the few complaints which did actually touch the Navigation Acts. The commissioners report it to the King as "an extravagant request for liberty to transport their tobacco to any of his Majesty's plantations without paying the imposts, payable by act of Parliament, etc. This head is wholly mutinous-to desire a thing contrary to his Majesty's royal pleasure and benefit and also against an act of Parliament.",29

Despite the obviously ruinous effects of the Navigation Acts upon Virginia, Mr. Beer makes the assertion that there was no very serious and general opposition to them in Virginia. "Apart from the criticisms of Bland and Berkeley," he says, 
"there was virtually no complaint against the system of trade enjoined by the Navigation Acts. While the Barbados Assembly and that colony's governors were vociferous in their protests, the Virginia legislature remained strangely mute."30

This silence on the part of the Virginia Assembly can by no means be interpreted as an indication that the people of the colony felt the Navigation Acts to be equitable and not injurious to their interests. It meant only that no Assembly under Sir William Berkeley would dare protest against an act which had received the royal sanction. That would have seemed the veriest treason to the fiery old loyalist. And the Assembly was entirely under Sir IVilliam's control. The members of both Houses were his creatures and his henchmen. Over and over again it is testified that the Assembly did nothing more than register his will. ${ }^{31}$ If then it did not protest, it was because Sir William did not wish it to protest.

But this does not prove that the planters were not angered and alarmed at the stringent acts. That they considered them baleful is amply proved by their continuous complaints of the economic ruin which had overtaken the colony. The method they chose of combatting the trade laws, a method apt to be far more effective than the angry protests of the Barbados Assembly, was to send the Governor to England to use his influence at Court to have the acts modified or repealed. And Berkeley did what he could. While in England he wrote a paper called $A$ Discourse and Vieze of Virginia, which he hoped would induce the Government to change its policy in regard to the colonies. "Wee cannot but resent," he said, "that 40,000 people should be impoverished to enrich little more than 40 merchants, who being the whole buyers of our tobacco, give us what they please for it. And after it is here sell as they please, and indeed have 40,000 servants in us at cheaper rates, than other men have slaves, for they find them 
meat and drink and clothes. We furnish ourselves and their seamen with meat and drink, and all our sweat and labor as they order us, will hardly procure us coarse clothes to keep us from the extremities of heat and cold." 32 That Sir William was but the mouthpiece of the colony in this protest there can be no doubt.

But his pleadings were in vain. England would not change the laws which were the expression of her settled colonial policy. The planters must adjust themselves to changed conditions no matter how bitter was the experience. Sir William was told to go home to report to the Virginians that they need not kick against the pricks, but that England would be most pleased could they turn from the all-absorbing culture of tobacco to the production of the raw materials she so greatly desired. And Berkeley did return determined to exert every effort to lead the colonists into new prosperity by inducing them to devote a part of their energies to basic commodities. In fact he promised that in seven years he would flood the British market with new Virginia goods. ${ }^{33}$

Although he set to work with his accustomed vigor to make good this boast, he met with but scant success. Lack of efficient and skilled labor, high wages, and not very favorable natural conditions, made it impossible for him to compete with the long-established industries of Europe. After a few years all attempts to make silk and potash and naval stores were abandoned, and the planters continued to put their trust in tobacco.

That Berkeley was never persuaded that the Navigation Acts were just or beneficial is shown by his answer to the query of the Lords of Trade in $167 \mathrm{I}$, when they asked him what impediments there were to the colony's trade. "Mighty and destructive," he replied, "by that severe act of Parliament which excludes us from having any commerce with any na- 
tion in Europe but our own, so that we cannot add to our plantation any commodity that grows out of it . . . for it is not lawful for us to carry a pipe-staff or a bushel of corn to any place in Europe out of the King's dominions. If this were for his Majesty's service or the good of his subjects we should not repine, whatever our sufferings are for it. But on my soul it is the contrary of both.", 35

Nor is this the only direct testimony that the colonists were filled with bitterness against the Navigation Acts. In I673, during the war with Holland, Sir John Knight declared that "the planters there do generally desire a trade with the Dutch and all other nations, and speak openly there that they are in the nature of slaves, so that the hearts of the greatest part of them are taken away from his Majesty and consequently his Majesty's best, greatest and richest plantation is in danger, with the planters' consent, to fall into the enemy's hands, if not timely prevented." 36 This is corroborated by the Council itself, in an official letter to the King. "For in this very conjuncture had the people had a distasteful Governor," they wrote, "they would have hazarded the loss of this Country, and the rather because they doe believe their Condicon would not be soe bad under the Dutch in Point of Traffique as it is under the Merchants who now use them hardly, even to extremity." 37

It is evident, then, that throughout the entire reign of Charles II the unhappy effects of the trade restrictions made of Virginia, which formerly had been the land of opportunity for the poor man, a place of suffering, poverty and discontent. The indentured servant who came over after I 660 found conditions in the colony hardly more favorable for his advancement than in England. The price of tobacco was now so low that it was not possible for a man, by his unassisted efforts, to make a profit by its cultivation. If Thomas Ludewell is correct in estimating the return from the average crop at fifty 
shillings, the lot of the poor man must have been hard indeed. Hungry he need not be, for food continued to be abundant and easy to obtain, but of all that the merchants gave him in return for his tobacco-clothing, farm implements, household furnishings--he had to content himself with the scantiest supply. And only too often his pressing needs brought him into hopeless debt. As for imitating his predecessors of the earlier period in saving money, purchasing land and servants and becoming a substantial citizen, the task was well nigh impossible of accomplishment.

It would be expected, then, that even the most exhaustive investigation could reveal but a few indentured servants, coming over after 1660 , who succeeded in establishing themselves in the Virginia yeomanry. And such, indeed, is the case. Fortunately we have at hand for the period in question the means of determining this matter with an exactness impossible for the first half of the century. Nicholson's rent roll of r 704 supplies a complete list, with the exception of those in the Northern Neck, of every landowner in Virginia. At the same time we have in the Land Office at Richmond, the names of many thousands of persons listed as headrights, constituting almost all the immigrants who came in during the years from I 666 to the end of the century. Thus by comparing the two lists and trying to identify on the rent roll the names found in the patents, it is possible to fix the proportion of servants who won for themselves at this time places among the landowning class.

Selecting the year 1672 as typical of the Restoration period, we find that an examination of 672 of the names which are listed as headrights, eleven only can be identified with any degree of certainty upon the rent roll. Of I I 6 names examined in the years from $167 \mathrm{I}$ to 1674 inclusive, only 26 are positively those of persons listed as landowners in 1704. After making 
due allowance for the fact that uncertainty exists in a number of other cases, and that some who prospered must have died in the intervening years, it is safe to say that not more than five or six per cent of the indentured servants of this period succeeded in establishing themselves as independent planters.

These conclusions are borne out by the slowness with which the population increased during the years following the passage of the Navigation Acts. In the Commonwealth period the colony had advanced by leaps and bounds, and the inhabitants, estimated at 15,000 in $1649,{ }^{38}$ were placed by Berkeley thirteen years later at $40,000 .^{39}$ Under the system which existed during these years, when the colonists enjoyed a comparatively free trade, the population had tripled. But after 1660 , while the Virginia tobacco was dumped upon the restricted English market and prices fell lower and lower, no such rapid growth is noted. In 1671 , nine years after his first estimate, Governor Berkeley still placed the population at 40,000. ${ }^{40}$ And even if we accept the statement of the Virginia agents sent to England to secure a charter for the colony that in 1675 the number of inhabitants was 50,000 , it is evident that some pernicious influence was at work to retard the development of England's most important American province. ${ }^{41}$ A drop in the rate of increase from 200 per cent cluring the thirteen years prior to 1662 , to 25 per cent in the thirteen years following, is a clear index to the startling change brought about in the colony by the British trade regulations.

These figures are the more significant in that there was no appreciable slackening of the stream of servants. It is probable that in the period from 1662 to 1675 , which marked this estimated increase of 10,000 persons, fully 20,000 immigrants had come to the colony. ${ }^{42}$ The patent rolls for 1674 alone give the names of I93 I headrights, and this year is by no means exceptional. No wonder Edward Randolph was sur- 
prised at the smallness of the population and wrote to the Board of Trade that it should be investigated why Virginia had not grown more, "considering what vast numbers of servants and others had been transported thither.",43

But Randolph failed to realize that it is not the volume of immigration but the number of people a country will support which in the end determines the size of the population. It was not enough to pour into the colony tens of thousands of poor settlers; opportunity had also to be afforded them for earning an adequate living. And this opportunity, because of the enforcement of the Navigation Acts and the consequent ruin of trade, they did not have in Virginia. Throughout the Restoration period not more than forty or fifty thousand people could exist upon the returns from the tobacco crop, and beyond that the population could hardly rise. If more poured in, they must of necessity live in misery and rags, or migrate to other colonies where more favorable conditions existed.

Ve are not at present concerned with what become of this surplus population, but only with the fact that the Navigation Acts brought to a dead halt the process of moulding freedmen and other poor settlers into a prosperous yeomanry. By the year 1660 this class seems to have reached its highest development, and had a rent roll of land owners been drawn up at that date it would doubtless have shown almost as many names as that of I704. In fact it is fortunate that in the bitter years from 1660 to 1685 it did not succumb entirely. With the price of tobacco so low that no profit was to be derived from it, with his family in rags, the small planter might well have sold his land to his more wealthy neighbor and joined the newly freed servants in moving on to western Carolina or to the northern colonies.

In fact it is an indication of the solid character of the Vir- 
ginia yeomanry that it survived to enter the Eighteenth century, that under Andros and Nicholson as well as under Sir William Berkeley it was the soundest element in the life of the colony. Had it not been for the crowning misfortune of the introduction of great swarms of negro slaves, sooner or later it would have come once more into its own, would have carved out for itself a new prosperity, would have filled Virginia from the Atlantic to the Alleghanies. 


\section{CHAPTER VI}

\section{The Yeoman in Virginia History}

Perhaps it would have been impossible for the Virginia yeoman to survive the dark days of the Restoration period had it not been for the fact that in the matter of his food supply he was independent of England and her vexatious trade restrictions. He might be in rags, but there was no reason why he should ever feel the pangs of hunger. Seldom in any climate, in any age has food existed in such extraordinary variety and in such lavish abundance.

Almost every planter, even the poorest, was possessed of cattle. The Perfect Discription states that in I649 there were in the colony "of Kine, Oxen, Bulls, Calves, twenty thousand, large and good."' Fifteen years later the number had increased to $100,000 .^{2}$ Many a little farmer, too poor to afford the help of a servant or a slave, had cattle more than sufficient for his every need. John Splitimber, a planter of meagre means, died in 1677 owning eight cows and one bull. ${ }^{3}$ John Gray, whose entire personal estate was valued only at 9,340 pounds of tobacco, possessed at his death six cows, six calves, two steers and one heifer. ${ }^{4}$ The inventory of the goods of Richard Avery, another poor planter, shows three steers, one heifer, three small cattle and one calf. ${ }^{5}$ The yeoman not only secured from these animals a goodly supply of beef, but milk in abundance from which he made butter and cheese. The steers he used as beasts of burden.

The meat which most frequently appeared upon the table of the poor man was that of swine. The planter marked his hogs and turned them loose in the woods to feed upon roots 
and acorns. On the other hand, sheep did not multiply in the colony, for the woods were not suited for their maintenance, and those areas which had been cleared of trees could more profitably be utilized for agriculture than for pasture lands. Mutton was a rare delicacy even with the well-to-do. ${ }^{6}$

Poultry were exceedingly numerous. At the time of the Company it was stated that the planter who failed to breed one hundred a year was considered a poor manager. The Perfect Discription says that the poultry- "Hens, Turkies, Ducks, Geece"-were without number." Moreover, the wild fowls of the inland waterways were so numerous that even the least skilful of huntsmen could readily bring down enough for the needs of his family, and the mallard, the goose, the canvasback appeared regularly in season upon every table. ${ }^{8}$

The planter always devoted a part of his land to the production of the grain which was needed for his personal requirements. "They yearly plow and sow many hundred acres of Wheat," it was said, "as good and faire as any in the world." At the same time maize grew so readily and its cultivation proved so cheap, that cornbread formed a part of the diet not only of the planters themselves, but of their servants and slaves.

From his garden, an inevitable accompaniment of every plantation, the farmer secured a large variety of vegetablespotatoes, asparagus, carrots, turnips, onions, parsnips, besides such fruits as strawberries, gooseberries, raspberries; from his orchard he had apples, pears, quinces, apricots, peaches. ${ }^{10}$ Honey was abundant, and there were few householders who did not have hives under the eaves of their outbuildings. One planter, a Mr. George Pelton, is said to have made a profit of $£_{30}$ from his bees. ${ }^{11}$ There were also many wild swarms in the woods, which yielded a delicious return to the colonial bee-hunters. ${ }^{12}$ 
It is easy to understand, then, why there were no complaints of hunger even in the days when poverty was almost universal. The Virginia yeoman spread always an abundant table. "He that is lazy and will not work," said the author of New Albion, "needs not fear starving, but may live as an Indian, sometimes Oysters, Cockles, Wilkes, Clams, Scollons two moneths together; sometimes wilde Pease and Vetches, and Long Oates, sometimes Tuckaho, Cuttenoman ground, Nuts, Marhonions, sometimes small nuts, Filbirds, Wallnuts, Pokeberries, ten sorts of Berries, Egs of Foul, small Fish in Coves at low water will teach him to live idly." "It must needs follow then that diet cannot be scarce, since both rivers and woods afford it, and that such plenty of Cattle and Hogs are every where, which yield beef, veal, milk, butter, cheese and other made dishes, porke, bacon and pigs, and that as sweet and savoury meat as the world affords, these with the help of Orchards and Gardens, Oysters, Fish, Fowle and Venison, certainly cannot but be sufficient for a good diet and wholsom accommodation, considering how plentifully they are, and how easie with industry to be had.", 13

But the little planter, with the advent of the Navigation Acts, often suffered keenly from a lack of adequate clothing. Again and again the letters of the period state that the poor man was reduced to rags, that he could not protect his family from the winter's cold. There was some manufacture of cloth in the home, but the planter usually trusted to the foreign trader to bring him every article of clothing. He had neither the implements nor the skill to supply his own needs. During the Restoration period, and again at the time of the war of the Spanish Succession, when the price of tobacco fell so very low, many families succeeded in producing enough homespun to supply their most pressing needs. ${ }^{14}$ But with the return of better conditions they laid aside the loom and the wheel, and resumed their purchase of English cloth. 
In normal times the poor planter was comfortably clad. Edward Williams, in Virginia Richly Valued, advised every new immigrant to bring a monmouth cap, a waistcoat, a suit of canvas, with bands, shirts, stockings and shoes. ${ }^{15}$ The author of New Albion thought that each adventurer should provide himself with canvas or linen clothes, with shoes and a hat. $^{16}$

The houses of the small planters were small but comfortable. "Pleasant in their building," says John Hammond, "which although for most part they are but one story besides the loft, and built of wood, yet contrived so delightfully that your ordinary houses in England are not so handsome, for usually the rooms are large, daubed and whitelimed, glazed and flowered, and if not glazed windows, shutters which are made very pritty and convenient." "The New Description of Virginia, published in I649, says: "They have Lime in abundance for their houses, store of bricks made, and House and Chimnies built of Brick, and some of Wood high and fair, covered with Shingell for Tyle." 18

In the days of the Company most of the houses seem to have been made of logs, and Butler, in his Virginia Unmasked. declared that they were the "worst in the world," and that the most wretched cottages in England were superior to them. ${ }^{19}$ But the period of which Butler wrote was exceptional, and before long the growing prosperity of the colony made possible a great improvement in the dwellings of the people. The rough log cabin gave way to the little framed cottage with chimneys at each end.

$A$ residence erected in one of the parishes of the Eastern Shore in 1635 to serve as a parsonage may be accepted as typical of the better class of houses in Virginia at this time. It was made of wood, was forty feet wide, eighteen deep and had a chimney at each end. On either side was an additional 
apartment, one used as a study, the other as a buttery. ${ }^{20}$ For the poor man this was far too pretentious, and he had to content himself with a home perhaps thirty by twenty feet, containing at times two or three apartments, at times only one.

But such as it was it gave him ample protection against the heat of summer and the cold of winter. Fuel he never lacked. When the frosts of December and January came upon him, he had only to repair to the nearest forest, axe in hand, to supply himself with wood in abundance. In this way, not only would he keep a roaring blaze in his open fireplace, but would widen the space available for the next summer's tobacco crop.

The surroundings of the planter's residence were severely plain. In the yard, which usually was uninclosed, towered a cluster of trees, a survival of the primeval forest. Nearby was the garden, with its flowers and vegetables, the dove-cote, the barn, the hen house, perhaps a milk house or even a detached kitchen. In some cases wells were sunk, but the use of natural springs was more common. ${ }^{21}$

Of the plantation itself, only a fraction was under cultivation at one time. Tobacco was exceedingly exhausting to the soil, but the cheapness of land led the planters to neglect the most ordinary precautions to preserve its fertility. They sowed year after year upon the same spot, until the diminishing yield warned them of approaching sterility, and then would desert it to clear a new field. This system made it necessary for them to provide for the future by securing farms far larger in extent than was dictated by their immediate requirements. They had to look forward to the day when their land would become useless, and if they were provident, would purchase ten times more than they could cultivate at any one time. Thomas Whitlock, in his will dated I659, says: "I give to my son Thomas Whitlock the land I live on, 600 acres, when he is of the age $2 \mathrm{I}$, and during his minority to my wife. The 
land not to be further made use of or by planting or seating than the first deep branch that is commonly rid over, that my son may have some fresh land when he attains to age."'22

One may gain an idea of the condition of the very poorest class of freemen by an examination of the inventory of the estate of Walter Dorch, drawn up in 1684 . This man possessed two pairs of woollen cards, and one spinning wheel, valued at 100 pounds of tobacco, one chest at eighty pounds, four old trays at twenty pounds, two runletts at forty pounds, one pail and one skillet at sixty pounds, one bowl at two pounds, one feather bed, two pillows and three old blankets at 120 pounds of tobacco, three glass bottles at twenty pounds, one couch frame at forty pounds, one pair of pot-hooks at forty, 800 tempenny nails at forty-five, and one old table and one sifter at twenty pounds. In all the estate was valued at 587 pounds of tobacco. ${ }^{23}$

John Gray, who died in $168_{5}$, left personal property worth 9,340 pounds of tobacco, consisting in part of six cows and six calves, four yearlings, two steers, one heifer, one barrel of corn, one bull, ten hogs and one horse. He had no servants and no slaves. ${ }^{24}$ In better circumstances was Richard Avery, who seems to have been a tanner by profession. The inventory of his estate, recorded in 1686 , includes one horse with bridle and saddle, a cart and a yoke of steers, eight head of cattle, 25 hogs, I 8 hides, various kinds of tools, lumber to the value of 400 pounds of tobacco, four pieces of earthenware, four beds with mattresses and covers, poultry to the value of I 80 pounds of tobacco, some wheat in the ground and a batch of wearing linen. The entire personal estate was valued at 14,050 pounds of tobacco. It included no servants or slaves. ${ }^{25}$

John Splitimber, who is entered as a headright to Thomas Harwood in 1635 , is typical of the planter who rose from small beginnings to a state of comparative prosperity. This man, at 
his death in 1677 , possessed eight cows, one bull, four yearlings, four mares, 35 hogs, two horses, two bolsters, a pillow, two blankets, a mattress, two bedsteads, two guns, fifty-six pounds of pewter, two rugs, a table, three chests, one old couch, two iron pots, two kettles, two stilyards, shovel and tongs, two smothering irons, two axes, a few carpenter's tools, a saddle and bridle, four casks, clothing to the value of I, IOO pounds of tobacco, a frying pan, a butter pat, a jar, a looking glass, two milk pans, one table cloth, nine spoons, a churn, a bible. The appraisers placed the total value at i 8,277 pounds of tobacco. $^{26}$ The inventory records no servants or slaves, but it is probable that Splitimber at times made use of indentured labor, as in November 1648 and again in 1652 , we find him taking up land due for the transportation of certain persons to the colony. ${ }^{27}$

Of similar estate was Christopher Pearson, of York county. His personal property included bedding valued at $\mathfrak{f}_{7}$, linen at I 8 shillings, pewter at $\mathfrak{E}$ I.I8.o, brass at six shillings, wooden ware at $\mathfrak{E}_{4}$. I 3.6 comprising three chairs and one table, a couch, four old chests, a cask, two ten gallon rundletts, a cheese press, a box of drawers, an old table, three pails, a spinning wheel with cards, two sifting trays, a corn barrel, three bedsteads, four sives, a funnel; iron ware valued at $£ 2.12 .0$, including three pots, two pot-rocks, a pestal, a frying pan, a looking glass; three cows appraised at $£ 6.5 .0$, a yearling at ten shillings, a colt at two pounds sterling. The entire estate was valued at $\mathfrak{E}_{25}$. $19 \cdot 6 .^{28}$

It must not be imagined, however, that Virginia, even in the early years of its settlement, contained no men of wealth or rank. Industry and intelligence bore their inevitable fruit in the little colony, with the result that here and there certain planters acquired an enviable pre-eminence among their fellows. The New Description mentions several such cases. 
Captain Matthews "hath a fine house," it says, "and all things answerable to it; he sowes yeerly store of Hempe and Flax, and causes it to be spun; he keeps Weavers, and hath a Tanhouse, causes Leather to be dressed, hath eight Shoemakers employed in their trade, hath forty Negro servants, brings them up to Trades in his house. He yeerly sowes abundance of Wheat, Barley, \&c. The Wheat he selleth at four shillings the bushell; kills store of Beeves, and sells them to victuall the Ships when they come thither: hath abundance of Kine, a brave Dairy, Swine great store, and Poltery; he married a Daughter of Sir Thomas Hinton, and in a word, keeps a good house, lives bravely, and a true lover of Virginia; he is worthy of much honor." 29

This description is interesting because it shows not only the extent of the holdings of certain planters at this early late, but that their prosperity had the same foundation as that of the more numerous class of wealthy men of the Eighteenth century. In both cases slavery and plantation manufacture would seem to have been the open sesame to success. It is notable that of the very limited number of men in Virginia prior to I 700 who stand out above their fellows in the readiness with which they acquired property, almost all gathered around them a goodly number of negroes.

Among the prominent planters of the first half of the Seventeenth century was George Menefie, famous for his orchard which abounded in apple, pear and cherry trees, and for his garden which yielded all kinds of fruits, vegetables, and flowers; Richard Bennett, a man of large property who had in one year "out of his Orchard as many Apples as he made 20 Butts of Excellent Cider"; Richard Kinsman, who for three or four years in succession secured "forty or fifty Butts of Perry made out of his Orchard, pure and good.",30

In the second half of the century the class of the well-to-do, 
although somewhat more numerous, was still restricted to a small group of prominent families, many of them connected by marriage. Among the best known men are Nathaniel Bacon, Sr., Thomas Ballard, Robert Beverely, Giles Brent, Joseph Bridger, William Byrd I, John Carter, John Custis I, Dudley Digges, William Fitzhugh, Lewis Burwell, Philip Ludwell I, William Moseley, Daniel Parke, Ralph Wormeley, Benjamin Harrison, Edward Hill, Edmund Jennings and Matthew Page. But so few were their numbers that the Governors more than once complained that they could not find men for the Council of State qualified for that post by their wealth and influence.

The depository of power for the Virginia yeomanry was the House of Burgesses. This important body was elected by the votes of the freeholders, and faithfully represented their interests. Here they would bring their grievances, here express their wishes, here defend themselves against injustice, here demand the enactment of legislation favorable to their class. The hope of the people lay always in the Burgesses, Bacon the rebel tells us, "as their Trusts, and Sanctuary to fly to." ${ }_{31}$ And though the commons usually elected to this body the leading men of each county, men of education and wealth if such were to be found, they held them to a strict accountability for their every action. ${ }^{32}$ Many of the best known members of the Council of State served their apprenticeship in the Burgesses. But whatever the social status of the Burgess, he felt always that he was the representative of the poor planter, the defender of his interests, and seldom indeed did he betray his trust. ${ }^{33}$ This no doubt was with him in part a matter of honor, but it also was the result of a consciousness that unless he obeyed the behests of his constituency he would be defeated if he came up for re-election.

The House of Burgesses, even in the days when the colony 
was but an infant settlement stretching along the banks of the James, did not hesitate to oppose the wishes of the King himself. In 1627 Charles I sent instructions for an election of Burgesses that he might gain the assent of the planters through their representatives to an offer which he made to buy their tobacco. ${ }^{34}$ Although the Assembly must have realized that its very existence might depend upon its compliance with the King's wishes, it refused to accept his proposal. ${ }^{35}$ In I634 Charles again made an offer for the tobacco, but again he encountered stubborn opposition. The Secretary of the colony forwarded a report in which he frankly told the British Government that in his opinion the matter would never go through if it depended upon the yielding of the Assembly. ${ }^{36}$

In 1635 the people again showed their independent spirit by ejecting Sir John Harvey from the Government and sending him back to England. It is true that the Council members took the lead in this bold step, but they would hardly have gone to such lengths had they not been supported by the mass of small planters. ${ }^{37}$ In fact, one of the chief grievances against the Governor was his refusal to send to the King a petition of the Burgesses, which he considered offensive because they had made it "a popular business, by subscribing a multitude of hands thereto." And some days before the actual expulsion Dr. John Pott, Harvey's chief enemy, was going from plantation to plantation, inciting the people to resistance and securing their signatures to a paper demanding a redress of grievances. ${ }^{38}$

The attitude of the small planters during the English civil war and Commonwealth period is equally instructive. Certain writers have maintained that the people of Virginia were a unit for the King, that upon the execution of Charles I his son was proclaimed with the unanimous consent of the planters, that the colony became a refuge for English cavaliers, 
that it surrendered to Parliament only when conquered by an armed expedition and that it restored Charles II as King of Virginia even before he had regained his power in England.

All of this is either misleading or entirely false. It is true that the Assembly proclaimed Charles II King in I649 and passed laws making it high treason for any person to uphold the legality of the dethronement and execution of his father. ${ }^{39}$ But this was largely the work of Sir William Berkeley and the small group of well-to-do men who were dependent upon him for their welfare. The very fact that it was felt necessary to threaten with dire punishment all who spread abroad reports "tending to a change of government," shows that there existed a fear that such a change might be effected. ${ }^{40}$ How many of the small planters were at heart friendly to Parliament it is impossible to say, but the number was large enough to cause Sir William Berkeley such serious misgivings as to his own personal safety that he obtained from the Assembly a guard of ten men to protect him from assassination. ${ }^{41}$

Nor can it be said that Virginia was forced into an unwilling submission to Parliament. It is true that an expedition was sent to conquer the colony, which entered the capes, sailed up to the forts at Jamestown and there received the formal surrender of the colony. ${ }^{42}$ But this surrender was forced upon the Governor as much by the wishes of the people as by the guns of the British fleet. In fact, the expedition had been sent at the request of certain representatives of the Parliamentary faction in Virginia, who made it clear to the Commonwealth leaders that the colony was by no means unanimous for the King, and that it was held to its allegiance only by the authority and firm will of the Governor. ${ }^{43}$ That the British Council of State expected to receive active assistance from their friends in Virginia is evident, for they gave directions for raising troops there and for appointing officers. ${ }^{44}$ And 
there can be no doubt that the imposing military force which had been gathered to defend Jamestown was not called into action chiefly because Berkeley became convinced that it could not be relied upon to fight against the Commonwealth soldiers.

The new regime which was introduced with the articles of surrender made of Virginia virtually a little republic. In England the long cherished hope of the patriots for self-govermment was disappointed by the usurpation of Oliver Cromwell. But the commons of Virginia reaped the reward which was denied their brothers of the old country. For a period of eight years all power resided in the House of Burgesses. This body, so truly representative of the small planter class, elected the Governor and specified his duties. If his administration proved unsatisfactory they could remove him from office. The Burgesses also chose the members of the Council. Even the appointing of officials was largely theirs, although this function they usually felt it wise to delegate to the Governor. ${ }^{45}$ In fact, Virginia was governed during this period, the happiest and most prosperous of its early history, by the small proprietor class which constituted the bulk of the population.

Nor is it true that the people voluntarily surrendered this power by acknowledging the authority of Charles II before the actual restoration in England. After the death of Cromwell, when the affairs of the mother country were in chaos and no man knew which faction would secure possession of the government, the Virginia Assembly asked Sir William Berkeley to act again as their chief executive. But it was specifically stipulated that he was to hold his authority, not from Charles, but from themselves alone. ${ }^{46}$ In this step the people were doubtless actuated by an apprehension that the monarchy might be restored, in which case it would be much to their advantage to have as the chief executive of the colony the former royal Governor; but they expressly 
stated that they held themselves in readiness to acknowledge the authority of any Government, whatever it might be, which succeeded in establishing itself in England. So far was Sir William from considering himself a royal Governor, that when the King actually regained his throne, he wrote with no little apprehension, begging forgiveness for having accepted a commission from any other source than himself. ${ }^{47}$

It was the small farmer class which suffered most from the despotic methods of Berkeley during the Restoration periodthe corrupting of the House of Burgesses, the heavy taxes, the usurpation of power in local government, the distribution of lucrative offices-and it was this class which rose in insurrection in 1676 . It is notable that in the course of Bacon's Rebellion the great mass of the people turned against the Governor, either approving passively of his expulsion, or actually aiding his enemies. When Sir William appealed for volunteers in Gloucester county while Bacon was upon the Pamunkey expedition, he could hardly muster a man. ${ }^{48}$ And the forces which eventually he gathered around him seem to have included only a handful of leading citizens, such men as Philip Ludwell, Nathaniel Bacon, Sr., Giles Brent and Robert Beverley, together with a mass of indentured servants and others who had been forced into service. It is this which explains the apparent cowardice of the loyal forces, who almost invariably took to their heels at the first approach of the rebels, for men will not risk their lives for a cause in which their hearts are not enlisted.

And though the small farmers lost their desperate fight, though their leaders died upon the scaffold, though the oppressive Navigation Acts remained in force, though taxes were heavier than ever, though the governors continued to encroach upon their liberties, they were by no means crushed and they continued in their legislative halls the conflict that 
had gone against them upon the field of battle. But the political struggle too was severe. It was in the decade from I678 to I688 that the Stuart monarchs made their second attempt to crush Anglo-Saxon liberty, an attempt fully as dangerous for the colonies as for England. The dissolving of the three Whig Parliaments, and the acceptance of a pension from Louis XIV were followed not only by the execution of liberal leaders and the withdrawal of town charters in the mother country, but by a deliberate attempt to suppress popular government in America. It was not a mere coincidence that the attack upon the Massachusetts charter, the misrule of Nicholson in New York, the oppressions of the proprietor in Maryland and the tyranny of Culpeper and Effingham in Virginia occurred simultaneously. They were all part and parcel of the policy of Charles II and James II.

These attempts met with failure in Virginia because of the stubborn resistance they encountered from the small farmer class and their representatives in the House of Burgesses. The annulling of statutes by proclamation they denounced as illegal; they protested bitterly against the appointment of their clerk by the Governor; they fought long to retain their ancient judicial privileges; they defeated all attempts of the King and his representatives in Virginia to deprive them of the right to initiate legislation and to control taxation. And with the Glorious Revolution of $1688-89$, which put an end forever to Stuart aggressions, they could feel that their efforts alone had preserved liberty in Virginia, that they might now look forward to long years of happiness and prosperity. The Virginia yeoman reckoned not with slavery, however, and slavery was to prove, in part at least, his undoing. 


\section{CHAPTER VII}

IVORLD TRADE

IN $\quad$ I682 the depression which for nearly a quarter of a century had gripped the tobacco trade, somewhat abruptly came to an end. "Our only commodity, tobacco, having the last winter a pretty quick market, hath encouraged ye planters," wrote Secretary Spencer to the Board of Trade in May, r683. ${ }^{1}$ Apparently the tide had turned. From this time until the beginning of the War of the Spanish Succession more than two decades later we hear little complaint from Virginia, while there are excellent reasons to suppose that the colony was experiencing a period of growth and prosperity.

In truth the tobacco trade, upon which the planters staked their all, now expanded with startling rapidity, and each year the merchants were forced to add more bottoms to the fleet which sailed for England from the Chesapeake. During the early years of the Restoration period tobacco exports from Virginia and Maryland had made but little advance. In I663 they amounted to $7,367,140$ pounds, six years later they were $9,026,046$ pounds. $^{2}$ In 1698 , however, the output of Virginia and Maryland was estimated by the merchant John Linton to be from 70,000 to 80,000 hogsheads. ${ }^{*}$ Since the hogshead usually contained from 500 to 600 pounds, these figures mean that the planters were then raising from 35 ,000,000 to 48,000 ,ooo pounds of tobacco. And this conclusion is supported by

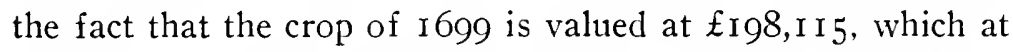
a penny a pound would indicate about $47,000,000$ pounds. ${ }^{5}$ In fact, the production of tobacco in the ten years from 1689 
to 1699 seems to have tripled, in the years from 1669 to 1699 to have quadrupled. In I669 the planters considered themselves fortunate if their industry yielded them a return of $£ 30,000$; at the end of the century they could count with a fair degree of certainty upon six times that amount.

For Virginia this startling development was all-important. During the darkest days of the Restoration period her share of the total returns from the tobacco crop could hardly have exceeded $\mathfrak{E}_{10,000}$; in 1699 it was estimated at $\mathfrak{E}_{100,000 .}$ Even if we accept the conservative statement that the average number of hogsheads exported from Virginia in the last decade of the century varied from 35,000 to $40,000,{ }^{6}$ the planters still would have received $\mathfrak{f}_{75}, 000$ or $\mathfrak{1} 80,000$. From dire poverty and distress the colony, almost in the twinkling of an eye, found itself in comparative ease and plenty.

Nor is the reason difficult to discover. It had never been the intention of the British Government to destroy the foreign trade of the colonies, the Navigation Acts having been designed only to force that trade through English channels. The planters were still at liberty to send their tobacco where they would, provided it went by way of England and paid the duty of a half penny a pound. That these restrictions so nearly put an end to shipments to the continent of Europe was an unfortunate consequence which to some extent had been foreseen, but which for the time being it was impossible to avoid.

It was undoubtedly the hope of the Government that the foreign market would eventually be regained and that the colonial tobacco would flow from the colonies into England and from England to all the countries of Europe. Prior to I660 Holland had been the distributing centre for the tobacco of Virginia and Maryland; now England insisted upon taking this rôle upon herself. But the authorities at London were hardly less concerned than the planters themselves at the 
difficulties encountered in effecting this change and the unfortunate glut in the home markets which followed.

None the less they persisted in the policy they had adopted, even clinging stubbornly to the half penny a pound re-export duty, and trusting that in time they could succeed in conquering for their tobacco the lost continental markets. In this they were bitterly opposed by the Dutch with whom it became necessary to fight two wars within the short space of seven years. Yet steadily, although at first slowly, they made headway. In I68I the commissioners of the customs refused the request for a cessation of tobacco planting in the colonies, on the ground that to lessen the crop would but stimulate production in foreign countries and so restrict the sale abroad of the Virginia and Maryland leaf. ${ }^{7}$ This argument has been denounced by some as both specious and selfish, yet it was fully justified by the situation then existing. After all, the only hope for the planters lay in conquering the European market and the way to do this was to flood England with tobacco until it overflowed all artificial barriers and poured across the Channel. And eventually this is just what happened. Since tobacco was piling up uselessly in the warehouses and much of it could not be disposed of at any price, it was inevitable that it should be dumped upon the other nations of Europe. There is in this development a close parallel with the commercial policy of Germany in the years prior to the world war, when no effort was spared to produce a margin of all kinds of wares over the home needs, which was to be exported at excessively low prices. This margin was a weapon of conquest, a means of ousting the merchants of other nations from this market or that. And when once this conquest had been effected, the price could be raised again in order to assure a profit to the German manufacturers. 
It is improbable that the English economists of the Seventeenth century, like those of modern Germany, had foreseen exactly what would happen, but the results were none the less similar. When once the English leaf had secured a strong hold upon the Baltic and upon France and Spain, it was a matter of the greatest difficulty to oust it, especially as the ever increasing influx of slaves made it possible for the planters to meet the lower prices of foreign competitors and still clear a profit. Thus it was that during the years from 1680 to 1708 the Chesapeake tobacco succeeded in surmounting all the difficulties placed in its way by the Navigation Acts, the necessity of the double voyage, the re-export duty of a half penny a pound, and so gradually flooded the continental market.

It is unfortunate that figures for re-exported tobacco during the earlier years of the Restoration period are lacking. In r688, however, it is stated that the duty of a half penny a pound was yielding the Crown an annual revenue of $\mathfrak{E}_{15}, 000$, which would indicate that about 7,200,000 pounds were leaving for foreign ports. ${ }^{8}$ Ten years later, if we may believe the testimony of John Linton, exports of tobacco totalled 50,000 or 60,000 hogsheads, or from $25,000,000$ to $30,000,000$ pounds. Not more than a fourth of the colonial leaf, he tells us, was consumed in England itself. ${ }^{9}$ Once more Virginia and Maryland were producing tobacco for all Europe, once more they enjoyed a world market.

This trade was extended from one end of the continent to the other. Vessels laden with American tobacco found their way not only to the ports of France and Holland and Spain, but even to the distant cities of Sweden and Russia. ${ }^{10}$ The Baltic trade alone amounted to from 5,000 to 10,000 hogs-

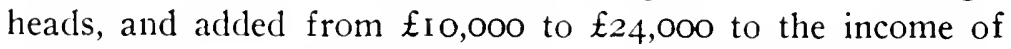
the planters. The chief Russian port of entry was Narva, 
which took annually some 500 hogsheads, but large quantities were shipped also to Riga and Raval. ${ }^{11}$ The northern nations bought the cheaper varieties, for no tobacco could be too strong for the hardy men of Sweden and Russia.

The trade was of great importance to England, as the leaf, after it had gone through the process of manufacture, sold for about six pence a pound, yielding to the nation in all from $£ 60,000$ to $£_{1} 30,000 .^{12}$ As the English were still largely dependent upon the Baltic for potash and ship stores, this constituted a most welcome addition to the balance of trade. To the colonies also it was vital, carrying off a large part of the annual crop, and so tending to sustain prices.

France, too, proved a good customer for English tobacco, and in the years prior to the War of the Spanish Succession took annually from 8,000 to Io,000 hogsheads, or from 4,000,ooo to $6,000,000$ pounds. ${ }^{13}$ Micajah Perry reported to the Lords of Trade that from 6,000 to 10,000 hogsheads went to France from London alone, while a very considerable amount was sent also from other ports. ${ }^{14}$

Far more surprising is the fact that even Spain consumed millions of pounds of English leaf. With her own colonies producing the best tobacco in the world and in the face of its practical exclusion from the English market, it is strange that the Government at Madrid should have permitted this commerce to continue. The obvious course for the Spaniards under the economic theories of the day would have been to exclude English tobacco, both in order to protect their own planters and to retaliate for the restrictions upon their product. Yet it is estimated that from 6,000 to I0,000 hogsheads entered Spain each year. ${ }^{15}$ A pamphlet published in 1708 entitled The Present State of Tobacco Plantations in America stated that before the outbreak of the war then raging, France and Spain together had taken annually about 20,000 hogsheads. ${ }^{16}$ 
The Dutch, too, despite their bitter rivalry with the British, found it impossible to do without Virginia tobacco. Purchasing the finest bright Orinoco, they mixed it with leaf of their own growth in the proportion of one to four, and sold it to other European nations. In this way they sought to retain their position as a distributing center for the trade and to give employment to hundreds of poor workers. In all the Dutch seem to have purchased from England about 5,000 hogsheads a year. ${ }^{17}$

The enhanced importance of the tobacco trade is reflected in a steady increase of British exports to Virginia and Maryland. The planters, now that they found it possible to market their leaf, laid out the proceeds in the manufactured products of England. At the end of the Seventeenth century the two colonies were importing goods to the value of $\{200,000$ annually. In I698, which was an exceptionally good year, their purchases were no less than $\mathfrak{E}_{3}$ IO, I $33{ }^{18}$

In short the tobacco colonies had at last found their proper place in the British colonial system. Both they and the mother country, after long years of experimentation, years of misfortune and recrimination, had reached a common ground upon which to stand. Although Maryland and Virginia still fell short of the ideal set for the British colonies, although they failed to furnish the raw stuffs so urgently needed by the home industries, at least they yielded a product which added materially to shipping, weighed heavily in the balance of trade and brought a welcome revenue to the royal Exchequer.

The Crown reaped a rich return from tobacco, a return which grew not only with the expansion of the trade, but by the imposition from time to time of heavier duties. In the perior from 1660 to $I 685$, when the tariff remained at 
two pence a pound, the yield must have varied from $\mathfrak{E}_{75}, 000$ to $£$ Ioo,ooo. If we assume that the average consumption in England was 9,000,000 pounds and the average exports $3,000,000$ the total revenue would have been $£ 81,250$. In I685, however, an additional duty of three pence a pound was placed upon tobacco upon its arrival in England, all of which was refunded when the product was re-exported. In I688, when the tobacco consumed in England was 8,328,800 pounds, the old and new duties, amounting in all to five pence, must have yielded $\mathfrak{f}_{\mathrm{I} 73,5 \mathrm{I} 5}$. When to this is added $\mathfrak{f}_{15,000}$ from the half penny a pound on the $7,200,000$ pounds of leaf sent abroad, the total reaches $\sum_{\mathrm{I}} 88,5$ I 5 .

In 1698 still another penny a pound was added to the tax, making a grand total of six pence on colonial tobacco disposed of in England. This new duty, together with the rapid increase in the foreign trade, enriched the Exchequer by another EIoo,ooo. In 1699, if we assume that $12,000,000$ pounds were consumed in England, the return would have been $\mathfrak{f}_{3} 00$,ooo; while half a penny a pound on $36,000,000$ pounds of reexported leaf, would have brought the total to $\mathfrak{f}_{375}$,000. That this figure was approximately correct we have evidence in the statement of the author of The Present State of the Tobacco Plantations, written in $\mathrm{I}_{705}$, that the revenue yielded by the tobacco of Virginia and Maryland amounted annually to $\mathfrak{f}_{400,000 .}{ }^{19}$ This sum constituted a very appreciable proportion of the royal income, so appreciable in fact as to make the tobacco trade a matter of vital importance in the eyes of the King's ministers. They were charged at all times to avoid any contingency which might lessen the imports and reduce the customs.

The increase in the tobacco trade stimulated industry, not only by increasing exports to Virginia and Maryland, but also 
by creating a new English industry. For most of the tobacco. before it was sent abroad, was subjected to a process of manufacture, by which the leaf was cut and rolled and otherwise prepared for the consumer. This industry gave employment to hundreds of poor persons in England and required a considerable outlay of capital. ${ }^{20}$

To British navigation the trade was vital. Each year scores of merchantmen crossed to the Chesapeake and swarmed in every river and creek, delivering their English goods to the planters and taking in return the hogsheads of tobacco. In 1690 the tobacco fleet numbered about Ioo ships, aggregating I 3,7 I 5 tons; in I 706 it counted no less than 300 sails. ${ }^{21}$ Nor must it be forgotten that re-exported tobacco also added many a goodly merchantman to the navy and gave employment to many a seaman. Altogether Virginia and Maryland constituted an invaluable asset, an asset which ranked in importance secondly only to the sugar plantations.

It would naturally be supposed that the fortunate turn of events which restored to the tobacco colonies their European market would have reacted favorably upon the small planters of Virginia, not only insuring plenty to those already established, but adding new recruits from the ranks of the indentured servants; that the process of making prosperous freemen from the poor immigrants who flocked to the colony, the process interrupted by the passage of the Navigation Acts, would have been resumed now that these laws no longer prevented the flow of tobacco into the continental countries.

Such was not the case, however. A comparison of the lists of immigrants with the rent roll of 1704 shows that but an insignificant proportion of the newcomers succeeded in establishing themselves as landowners. In four lists examined for the year 1689 , comprising 332 names, but seven persons can 
be positively identified upon the rent roll. In I690, eight lists of 933 names, reveal but twenty-eight persons who were landowners in I704. Of 274 immigrants listed in $169 \mathrm{I}$, six only appear on the Roll. In 1695 , seven lists comprising 7 I names, show but ten who possessed farms nine years later. Of 74 headrights appearing in 1696 , but two are listed on the roll; of II9 in 1697 only nine; of 169 in 1698 one only; of 454 in 1699 , only seven; of 223 in 1700 but six. ${ }^{22}$ All in all not more than five per cent. of the newcomers during this period prospered and became independent planters. Apparently, then, the restored prosperity of the colony was not shared by the poorer classes, the increased market for tobacco did not better materially the chances of the incoming flood of indentured servants.

The explanation of this state of affairs is found in the fact that tobacco, despite its widened market, experienced no very pronounced rise in price. The average return to the planters during the good years seems to have been one penny a pound. ${ }^{23}$ This, it is true, constituted an advance over the worst days of the Restoration period, but it was far from approaching the prices of the Civil war and Commonwealth periods. For the poor freedman, it was not sufficient to provide for his support and at the same time make it possible to accumulate a working capital. He could not, as he had done a half century earlier, lay aside enough to purchase a farm, stock it with cattle, hogs and poultry, perhaps even secure a servant or two. Now, although no longer reduced to misery and rags as in the years from I660 to 1682 , he could consider himself fortunate if his labor sufficed to provide wholesome food and warm clothing. How, it may be asked, could Virginia and Maryland produce the vast crops now required by the foreign trade, if the price was still so low? Prior to and just after Bacon's Rebellion the planters repeatedly asserted that their labors only served 
to bring them into debt, that to produce an extensive crop was the surest way for one to ruin himself. Why was it that twenty years later, although prices were still far below the old level, they could flood the markets of the world?

The answer can be summed up in one word-slavery. The first cargo of negroes arrived in the colony in I6I9 upon a Dutch privateer. Presumably they were landed at Jamestown, and sold there to the planters. ${ }^{24}$ The vessel which won fame for itself by this ill-starred action, was sailing under letters of marque from the Prince of Orange and had been scouring the seas in search of Spanish prizes. Although the Dutch master could have had no information that slaves were wanted in the colony, he seems to have taken it for granted that he would not be forbidden to dispose of his human freight.

The introduction of this handful of negroes-there were butt wenty in all - was not the real beginning of the slave system in the colonies. For many years the institution which was to play so sinister a part in American history did not flourish, and the slaves grew in numbers but slowly. In the Muster Roll of Settlers in Virginia, taken in 1624 , there were listed only 22 negroes. ${ }^{25}$ Sixteen years later the black population probably did not exceed $\mathrm{I}_{50}{ }^{26}$ In 1649 , when Virginia was growing rapidly and the whites numbered i 5,000 , there were but 300 negroes in the colony. ${ }^{27} \mathrm{~A}$ sporadic importation of slaves continued during the Commonwealth period, but still the number was insignificant, still the bulk of the labor in the tobacco fields was done by indentured servants and poor freeholders.

1 In 1670 Governor Berkeley reported to the Board of Trade that out of a total population of 40,000 , but five per cent were slaves. ${ }^{28}$ Eleven years later the number of blacks was estimated at $3,000 .^{29}$ In 1635 twenty-six negroes were brought in, the largest purchaser being Charles Harmar. ${ }^{30}$ In 1636 
the importations were but seven, in 1637 they were 28 , in I638 thirty, in I639 forty-six, in I642 seven only, in I643 eighteen, in 1649 seventeen. ${ }^{31}$ But with the passage of the years somewhat larger cargoes began to arrive. In 1662 Richard Lee claimed among his headrights no less than 80 negroes, in 1665 the Scarboroughs imported thirty-nine. In I670, however, Berkeley declared that "not above two or three ships of Negroes" had arrived in the province in the previous seven years. ${ }^{32}$

It is evident, then, that during the larger part of the Seventeenth century slavery played but an umimportant rôle in the economic and social life of the colony. The planters were exceedingly anxious to make use of slave labor, which they considered the foundation of the prosperity of their rivals of the Spanish tobacco colonies, but slave labor was most difficult to obtain. The trade had for many years been chiefly in the hands of the Dutch, and these enterprising navigators sold most of their negroes to the Spanish plantations. Ever since the days of Henry VIII the English had made efforts to secure a share of this profitable traffic, but with very meagre success. ${ }^{33}$

The Dutch had established trading stations along the African coast, guarded by forts and war vessels. Any attempts of outsiders to intrude upon the commerce was regarded by them as an act of open aggression to be resisted by force of armis. To enter the trade with any hope of success it became necessary for the English to organize a company rich enough to furnish armed protection to their merchantmen. But no such organization could be established during the Civil War and Commonwealth periods, and it was not until i660 that the African Company, under the leadership of the Duke of York entered the field. ${ }^{34}$

This was but the beginning of the struggle, however. The Dutch resisted strenuously, stirring up the native chieftians 
against the English, seizing their vessels and breaking up their stations. Not until two wars had been fought was England able to wring from the stubborn Netherlanders an acknowledgment of her right to a share in the trade. Even then the Virginians were not adequately supplied, for the sugar islands were clamoring for slaves, and as they occupied so important a place in the colonial system they were the first to be served. Throughout the last quarter of the Seventeenth century negroes in fairly large numbers began to arrive in the Chesapeake, but it was only in the years from I 700 to 1720 that they actually accomplished the overthrow of the old system of labor and laid the foundations of a new social structure. Throughout the Seventeenth century the economic system of the tobacco colonies depended upon the labor of the poor white man, whether free or under terms of indenture; in the Eighteenth century it rested chiefly upon the black shoulders of the African slave.

There could be no manner of doubt as to the desirability of the slaves from an economic standpoint, apparently the only standpoint that received serious consideration. The indentured servant could be held usually for but a few years. Hardly had he reached his greatest usefulness for his master than he demanded his freedom. Thus for the man of large means to keep his fields always in cultivation it was necessary constantly to renew his supply of laborers. If he required twenty hands, he nutst import each year some five or six servants, or run the risk of finding himself running behind. But the slave served for life. The planter who had purchased a full supply of negroes could feel that his labor problems were settled once and for all. Not only could he hold the slaves themselves for life, but their children also became his property and took their places in the tobacco fields as soon as they approached naturity. 
Thus in the end the slave was far cheaper. The price of a servant depended largely upon the cost of his passage across the ocean. We find that William Matthews, having three years and nine months to serve, was rated in the inventory of his master, John Thomas, at $\mathfrak{E}_{12}{ }^{35}$ A servant of Robert Leightenhouse, having two years to serve, was put at $f_{9} ;^{36}$ while on the other hand we find another listed in the estate of Colonel Francis Epes, also having two years to serve, at only $\mathcal{E}_{5} \cdot{ }^{37}$ A white lad under indenture for seven years to Mr. Ralph Graves was valued at $£$ IO. $^{38}$ On the whole it would seem that the price of a sturdy man servant varied from $\mathfrak{E}_{2}$ to $\mathfrak{E}_{4}$ for each year of his service. On the other hand a vigorous slave could be had at from $\mathfrak{f}_{\mathrm{I}} \delta$ to $\mathfrak{£}_{3} \mathrm{O}$. Assuming that he gave his master twenty-five years of service, the cost for each year would be but one pound sterling. There could be no doubt, then, that in the mere matter of cost he was much cheaper than the indentured white man.

It is true that the negro was none too efficient as a laborer. Born in savagery, unacquainted with the English tongue, knowing little of agriculture, it was a matter of some difficulty for him to accustom himself to his task in the tobacco fields. Yet when his lesson had been learned, when a few years of experience had taught him what his master expected him to do, the slave showed himself quite adequate to the requirements of the one staple crop. The culture of tobacco is not essentially difficult, especially when pursued in the unscientific manner of the colonial period. It required many, but not skilled hands. The slave, untutored and unintelligent, proved inadequate to the industrial needs of the northern colonies. The niceties of shipbuilding were beyond his capacities, he was not needed as a fisherman, he was not a good sailor, he was useless in the system of intensive agriculture in vogue 
north of Maryland. But in the tobacco field he would do. He could not at first tend so many plants as his white rival, he could not produce tobacco of such fine quality, but what he lacked in efficiency he more than made up for in cheapness.

The African seems to have withstood remarkably well the diseases indigenous to eastern Virginia. There are occasional reports of epidemics among the slaves, but usually they were fairly immune both to malaria and dysentery. A census taken in I I I , when there were perhaps I5,O00 negroes in the colony, records burials for sixty-two slaves only. ${ }^{39}$ The births of slaves for the same year totalled $253 .{ }^{40}$ These figures indicate not only the excellent physical condition in which these black workers were kept by their masters, but the rapidity with which they were multiplying. The low death rate is in part explained by the fact that only strong men and women were transported to the colonies, but it is none the less clearly indicative of the ease with which the African accustomed himself to the climate of tidewater Virginia.

As a rule the negro was more docile than the white servant, especially if the latter happened to be from the ruder elements of English society. He was not so apt to resist his master or to run away to the mountains. Yet plots among the blacks were not unknown. In I7IO a conspiracy was discovered among the slaves of Surry and James City counties which was to have been put into execution on Easter day. The negroes planned to rise simultaneously, destroy any who stood in their way, and make good their escape out of the colony. Among the chief conspirators were Jamy, belonging to $\mathrm{Mr}$. John Broadnax, Mr. Samuel Thompson's Peter, Tom and Cato of Mr. William Edwards, Great Jack and Little Jack of Mr. John Edwards, and Will belonging to Mr. Henry Hart. "Two or three of these were tried this general court," wrote Colonel Jennings, "found guilty and will be executed. And I hope 
their fate will strike such a terror in the other Negroes as will keep them from forming such designs for the future."41 The lesson did not prove lasting, however, for in I730 a number of slaves from Norfolk and Princess Anne counties assembled while the whites were at church, and chose officers to command them in a bold stroke for freedom. As in the previous attempt they were discovered, many arrested and several of the ringleaders executed. ${ }^{42}$

Neither the merchants nor the planters seem to have been conscious of any wrong in the seizure and sale of negroes. They regarded the native Africans as hardly human, mere savages that were no more deserving of consideration than oxen or horses. And as it was right and proper to hitch the ox or the horse to the plow, so it was equally legitimate to put the negro to work in the fields of sugar cane or tobacco. Whatever hardships he had to endure upon the voyage to America or by reason of his enforced labor, they considered amply compensated by his conversion to Christianity.

It is true that the colony of Virginia early in the Eighteenth century imposed a heavy duty upon the importation of slaves, but it did so neither from any consciousness of wrong in slavery itself or a perception of the social problems which were to grow out of it. At the time the price of tobacco was declining rapidly and many planters were losing money. Feeling that their misfortunes arose from overproduction, which in turn was the result of the recent purchases of negroes, the colonial legislators decided to check the trade. "The great number of negroes imported here and solely employed in making tobacco," wrote Governor Spotswood in I7II, "hath produced for some years past an increase in tobacco far disproportionate to the consumption of it . . and consequently lowered the price of it." ${ }^{43}$ "The people of Virginia will not now be so fond of purchasing negroes as of late," 
declared President Jennings of the Virginia Council in $\mathrm{I} 708$, "being sensibly convinced of their error, which has in a manner ruined the credit of the country."

During the years from I 680 to I 700 slaves arrived in the colony in increasing numbers. In I68r William Fitzhugh, in a letter to Ralph Wormeley, refers to the fact that several slave ships were expected that year in the York river. ${ }^{45}$ At this period, for the first time in Virginia history, we find negroes in large numbers entered as headrights upon the patent rolls. In 1693 Captain John Storey received a grant of land for the importation of 79 negroes, in I694 Robert Beverley brought in seventy, in I695 William Randolph twenty-five. ${ }^{46}$ Before the end of the century it is probable that the slaves in Virginia numbered nearly 6,000 , and had already become more important to the economic life of the colony than the indentured servants. ${ }^{47}$

The chief purchasers at this time were men of large estates. The advantages of slave labor were manifest to planters of the type of William Byrd or William Fitzhugh, men who had built up fortunes by their business ability. It is but natural that they should have turned early from the indentured servant to stock their plantations with the cheaper and more remunerative African workers.

As the English secured a stronger hold upon the African trade slaves arrived in ever increasing numbers. During the years from I 699 to 1708 no less than 6,843 came in, a number perhaps exceeding the entire importations of the Seventeenth century. ${ }^{48}$ In the summer of 1705 alone 1,800 negroes arrived. ${ }^{40}$ With what rapidity the black man was taking the place of the indentured servant and the poor freeman as the chief laborer of the colony is shown by the fact that in 1708 , in a total tithable list of 30,000 , no less than 12,000 were slaves. President Jennings at the same time reported that 
the number of servants was inconsiderable." "Before the year I680 what negroes came to Virginia were usually from Barbadoes," Jennings told the Board of Trade in 1708 . "Between I680 and I 698 the negro trade become more frequent, tho not in any proportion to what it hath been of late, during which the African Company have sent several ships and others by their licence having bought their slaves of the Company brought them here for sale, among which lately Alderman Jeffreys and Sir Jeffry Jeffreys were principally concerned." ${ }_{51}$

The wars of Charles XII, however, which proved disastrous to the Baltic trade, and the War of the Spanish Succession which cut off exports of tobacco to France and Spain, caused a serious decline in prices and made it impossible for the planters to continue the large purchases of slaves. This fact, together with the duty which had been imposed with the express purpose of keeping them out, reduced the importations to a minimum during the years from izio to $1718 .^{52}$ But with the reopening of the tobacco market and the return of prosperity to Virginia, the black stream set in again with redoubled force. In I730, out of a total population of I I 4,000, no less than 30,000 were negroes. ${ }^{53}$ In other words the slaves, who in 1670 had constituted but five per cent of the people, now comprised twenty-six per cent. Slavery, from being an insignificant factor in the economic life of the colony, had become the very foundation upon which it was established.

As we have seen it was not slavery but the protracted accumulation of surplus stocks of tobacco in England which had broken the long continued deadlock of the tobacco trade during the Restoration period and caused the overflow into continental markets. That the labor of blacks at first played no essential part in the movement is evident from the fact that in 1682 when it first became pronounced, the slave popula- 
tion of Virginia and Maryland was still insignificant. But that the trade not only continued after the glut in England had been cleared up, but increased with startling rapidity, was unquestionably the result of more universal use of negroes in the years immediately preceding the War of the Spanish Succession. Slavery so cheapened the cost of production that it was now quite possible for those who used them to pay the half penny a pound duty on reëxported tobacco in England, and still undersell all rivals in the European market. Before many years had passed the tobacco trade, with all that it meant both to England and to the colonies, rested almost entirely upon the labor of the savage black man so recently brought from the African wilds.

That this fact was fully understood at the time is attested by various persons interested in the colony and the trade. In I 728 Francis Fane, in protesting against the imposition of a new tax in Virginia on the importation of slaves declared "that Laying a Duty on Negroes can only tend to make them scarcer and dearer, the two things that for the good of our Trade and for the Benefit of Virginia ought chiefly to be guarded against, since it is well known that the cheepness of Virginia tobacco in European Marketts is the true Cause of the great Consumption thereof in Europe, and one would have therefore Expected rather to have seen an Act allowing a premium on the Importation of Negroes to have Encouraged the bringing them in, than an Act laying so large a Duty to discourage their Importation." ${ }_{54}$ Similarly Colonel Spencer wrote to the Board of Trade. "The low price of tobacco requires it should be made as cheap as possible. The Blacks can make it cheaper than Whites, so I conceive it is for his Majesty's interest full as much as the Country's or rather much more, to have Blacks as cheap as possible in Virginia."s5

It is evident, then, that the opening of the European market 
and the vast expansion of the tobacco trade, while bringing prosperity to the larger planters, was no great boon to the man who tilled his fields with his own hands. It assured him a ready sale for his crop, it is true, but at prices so low as to leave him a very narrow margin of profit. The new era which was opening, the so-called golden era of Virginia history, was not for him. Virginia in the Eighteenth century was to be the land of the slave holder, not of the little planter. 


\section{CHAPTER VIII}

\section{Beneath the Black Tide}

The importation of slaves in large numbers reacted almost immediately upon the migration of whites to Virginia. As we have seen, the stream of indentured servants that poured across the Atlantic remained remarkably constant throughout almost all of the Seventeenth century. The larger planters were always in need of laborers, and they looked to the surplus population of England to supply them. But with the coming of the blacks all was changed. The Virginians saw in the slave ships which now so frequently entered their rivers the solution of all their problems. And so the influx of white men and women from the mother country dwindled and almost died out, while in its place came a still greater stream from the coast of Africa.

At the time of Bacon's Rebellion the annual importation of servants was between $I, 500$ and 2,000. The headrights for I674 show I93I names. ${ }^{1}$ Seven years later the whites dvere still arriving in large numbers, the rolls for I 682 having I, 565 names. As the century drew to a close, however, the effect of the slave trade upon white immigration is reflected in the dwindling number of headrights. The change that was taking place is illustrated by a patent of 13,500 acres to Ralph Wormleley for the transportation of 249 persons, 149 of whom were white and Ioo black. ${ }^{2}$ Yet so late as I 704 the servants were still coming in appreciable numbers. In I 708 however, the number of servants at work in the colony had dwindled away almost entirely. ${ }^{3}$ In I7 5 the names of white persons listed as headrights was but ninety-one; in I7I 8 but IOI.* In other 
words, the first great migration of Englishmen to continental America, a migration extending over a century and comprising from IOO,OOO to I 50,000 men, women and children, had practically come to an end.

English statesmen at the time looked upon this event as an unalloyed blessing. The day had passed when they felt that there existed a surplus of labor at home and that the country was in need of blood letting. The proper policy was to keep Englishmen in England, to devote their energies to local industries and so strengthen the economic and military sinews of the nation. And if unemployment existed, it was the correct policy to bring work to the idle rather than send the idle out of the country in quest of work." And the colonies were to be utilized, no longer as outlets for the population, but as a means to the upbuilding of local industry. They were to supply a market for English goods, keep employed English mariners and furnish the tobacco and sugar which when reexported weighed so heavily in the balance of trade. And since these great staple crops could be produced by the work of slaves, it was thought highly advantageous for all concerned that the negro should replace the white servant in both the tobacco and the sugar fields. The planters would profit by the lowered cost of production, English industry would gain by the increased volume of traffic, the Crown revenues would be enhanced and English laborers would be kept at home. ${ }^{6}$

Apparently the deeper significance of this great movement was entirely lost upon the British economists and ministers. They had no conception of the advantage of having their colonies inhabited by one race alone and that race their own. From the first their vision was too restricted to embrace the idea of a new and greater Britain in its fullest sense. They could not bring themselves to look upon the soil of Virginia and Maryland as a part of the soil of an extended 
England, upon the Virginians and Marylanders as Englishmen, enjoying privileges equal to their own. They could not realize the strength that would come from such an empire as this, the mighty future it would insure to the Anglo-Saxon race.

Their conception was different. The British empire must consist of two distinct parts-mother country and colonies. And in any clash of interest between the two, the former must prevail. It was not their intent that the colonies should be purposely sacrificed, that they should be made to pay tribute to a tyrannical parent. In fact, they earnestly desired that the plantations should prosper, for when they languished English industry suffered. But in their eyes the colonies existed primarily for the benefit of England. England had given them birth, had defended them, had nurtured them; she was amply justified, therefore, in subordinating them to her own industrial needs.

Thus they viewed the substitution of the importation of slaves to the tobacco colonies for the importation of white men purely from an English, not an Anglo-Saxon, point of view. $\mathrm{Had}$ it been a question of bringing thousands of negroes to England itself to drive the white laborers from the fields, they would have interposed an emphatic veto. But with the structure of colonial life they were not greatly concerned. In I693, when James Blair secured from the King and Queen a gift for his new college at Williamsburg, Attorney-General Seymour objected vigorously, stating that there was not the least occasion for such an institution in Virginia. Blair reminded him that the chief purpose of the college was to educate young men for the ministry and begged him to consider that the people of the colony had souls to be saved as well as the people of England. "Souls! Damn your souls," snapped the Attorney-General, "make tobacco." " It would be unfair to say that 
the British Government took just the same view of the colonists as did Seymour, but there can be no doubt that their chief concern in the plantations was centered upon the size of their exports to England and of their purchases of English goods. And as the slaves could make more tobacco than the indentured servants, it became the settled policy of the Crown to encourage the African trade in every possible way.

The influx of slaves not only put almost a complete end to the importation of white servants, but it reacted disastrously upon the Virginia yeomanry. In this respect we find a close parallel with the experience of ancient Rome with slave labor. In the third and second centuries before Christ the glory of the republic lay in its peasantry. The self-reliant, sturdy, liberty-loving yeoman formed the backbone of the conquering legion and added to the life of the republic that rugged strength that made it so irresistible. "To say that a citizen is a good farmer is to reach the extreme limit of praise," said Cato. Some of the ablest of the early Roman generals were recruited from the small farmer class. Fabius Maximus, the Dictator, in need of money, sent his son to Rome to sell his sole possession, a little farm of seven jugera. Regulus, while in Africa, asked that he be recalled from his command because the hired man he had left to cultivate his fields had fled with all his farm implements, and he feared his wife and children would starve. ${ }^{8}$

This vigorous peasantry was destroyed by the importation of hordes of slaves and the purchase of cheap foreign grain. So long as the wars of Rome were limited to Italy the number of slaves was comparatively small, but as her armies swept over the Mediterranean countries one after another and even subdued the wild Gauls and Britains, an unending stream of captives poured into the city and filled to overflowing the slave markets. Cicero, during his short campaign against the 
Parthians wrote to Atticus that the sale of his prisoners had netted no less than 12,000,000 sestercias. In Epirus 100,000 men were captured; 60,000 Cimbries and I00,000 Germans graced the triumph of Marius; Caesar is said to have taken in Gaul another roo,ooo prisoners. Soon the slave became the cheapest of commodities, and he who possessed even the most extensive lands could readily supply himself with the labor requisite for their cultivation.

Thus thrown into competition with slave labor the peasant proprietor found it impossible to sustain himself. The grain which he produced with his own hands had to compete in the same market with that made by slaves. It must, therefore, sell for the same price, a price so low that it did not suffice to feed and clothe him and his family. So he was forced to give up his little estate, an estate perhaps handed down to him by generations of farmers, and migrate to the city of Rome, to swell the idle and plebeian population. And once there he demanded bread, a demand which the authorities dared not refuse. So the public treasury laid out the funds for the purchase of wheat from all parts of the world, from Spain, from Africa, from Sicily, wheat which was given away or sold for a song. This in turn reacted unfavorably upon the peasants who still clung to the soil in a desperate effort to wring from it a bare subsistence, and accelerated the movement to the city.

Thus Italy was transformed from the land of the little farmer into the land of big estates cultivated by slaves. A sad development surely, a development which had much to do with the decay and final overthrow of the mighty structure of the Roman Empire. In former times, Titus Livius tells us, "there was a multitude of free men in this country where today we can hardly find a handful of soldiers, and which would be a wilderness were it not for our slaves." "The plough is 
everywhere bereft of honor," wrote Virgil, while Lucian bewailed the departed peasants whose places were taken by fettered slaves. ${ }^{9}$

The importation of slaves to Virginia had somewhat similar results. While not destroying entirely the little farmer class, it exerted a baleful influence upon it, driving many families out of the colony, making the rich man richer, reducing the poor man to dire poverty. Against this unfortunate development the Virginia yeoman was helpless. Instinctively he must have felt that the slave was his enemy, and the hatred and rivalry which even today exists between the negro and the lowest class of whites, the so-called "poor white trash," dates back to the Seventeenth century.

The emigration of poor persons, usually servants just freed, from Virginia to neighboring colonies was well under way even at the time of Bacon's Rebellion. In I 677 complaint was made of "the inconvenience which arose from the neighborhood of Maryland and North Carolina," in that Virginia was daily deprived of its inhabitants by the removal of poor men hither. Runaway servants were welcomed in both places, it was asserted, while the debtor was accorded protection against prosecution. ${ }^{10}$ This early emigration was caused, of course, not by the importation of slaves, for that movement had not yet assumed important proportions, but by the evil consequences of the Navigation Acts. The Virginia yeoman moved on to other colonies because he found it impossible to maintain himself at the current price of tobacco.

The continuance of the movement, for it persisted for a full half century, must be ascribed to the competition of negro labor. Like the Roman peasant, the Virginia yeoman, to an extent at least, found it impossible to maintain himself in the face of slave competition. The servant, upon the expiration of his term, no longer staked off his little farm and settled 
down to a life of usefulness and industry. The poor planter who had not yet fully established himself, sold or deserted his fields and moved away in search of better opportunities and higher returns.

This migration was not the first of its kind in the English colonies, for the movement of Massachusetts congregations into the valley of the Connecticut antedated it by several decades. Yet it furnishes an interesting illustration of the lack of permanency in American life, of the facility with which populations urged on by economic pressure of one kind or another change localities. The great movement westward over the Appalachian range which followed the War of I8I2, the pilgrimages of homesteaders to the northwest and the Pacific coast, find their precedent in the exodus of these poor families from the tobacco fields of Virginia.

In the last decade of the Seventeenth century the migration assumed such large proportions that the Board of Trade became alarmed and directed Francis Nicholson to enquire into its cause in order that steps might be taken to stop it. The enigrant stream that directed itself northward did not halt in eastern Maryland, for conditions there differed little from those in Virginia itself. The settlers went on to the unoccupied lands in the western part of the colony, or made their way into Delaware or Pennsylvania. "The reason why inhabitants leave this province," wrote Nicholson, while Governor of Maryland, "is, I think, the encouragement which they receive from the Carolinas, the Jerseys, and above all from Pennsylvania, which is so nigh that it is easy to remove thither. There handicraft tradesmen have encouragement when they endeavor to set up woolen manufactures." "11

Although this explanation does not go to the root of the matter, it was in part correct. The northern colonies held out far greater opportunities for the poor man than the slave 
choked fields of tidewater Maryland and Virginia. The industries of Pennsylvania and Delaware and the Jerseys demanded a certain degree of skill and yielded in return a very fair living. In other words, the poor settlers in Virginia, finding that tobacco culture was now based upon the cheap labor of African slaves, moved away to other localities where intelligence still brought an adequate reward.

The Maryland House of Delegates, when asked to give their opinion in this matter, thought that it was a desire to escape the payment of debts which made some of the "meaner inhabitants" seek shelter in Delaware Bay and the Carolinas. They came nearer the real cause when they added that the low price paid by the merchants for tobacco obliged many to leave. ${ }^{12}$ Nicholson was not satisfied with this answer. "They will not directly own," he wrote, "that setting up manufactures and handicraft-trades in Pennsylvania, the large tracts of land held by some persons here and the encouragement given to illegal traders are the causes that make people leave this province. They would have it that they wish to avoid the persecution of their creditors, which causes them to shelter themselves among the inhabitants of the Lower Counties of Delaware Bay and of Carolina. The low price of tobacco has obliged many of the planters to try their fortune elsewhere, and the currency of money in Pennsylvania, which here is not, draws them to that province from this." ${ }_{13}$

In Virginia the difficulty of securing desirable land because of the large tracts patented by rich planters was usually assigned as the reason for the migration of poor families. This view of the matter was taken by Edward Randolph, the man who had won the undying hatred of the people of Massachusetts by his attempts to enforce the Navigation Acts there and by his attacks upon their charter. In I696 Randolph did Virginia the honor of a visit, and although encountering there 
none of the opposition which had so angered him in New England, he sent to the Board of Trade a memorial concerning the colony, criticising the government severely. It should be inquired into, he said, how it comes to pass that the colony (the first English settlement on the continent of America, begun above 80 years ago) is not better inhabited, considering what vast numbers of servants and others have yearly been transported thither... The chief and only reason is the Inhabitants and Planters have been and at this time are discouraged and hindered from planting tobacco in that colony, and servants are not so willing to go there as formerly, because the members of the Council and others, who make an interest in the Government, have from time to time procured grants of very large Tracts of land, so that there has not for many years been any waste land to be taken up by those who bring with them servants, or by such Servants, who have served their time faithfully with their Masters, but it is taken up and ingrossed beforehand, whereby they are forced to hyer and pay a yearly rent for some of those Lands, or go to the utmost bounds of the Colony for Land, exposed to danger and often times proves the Occasion of Warr with the Indians." ${ }^{14}$

For their large holdings the wealthy men paid not one penny of quit rents, Randolph said, and failed to comply with the regulations for seating new lands. The law demanded that upon receipt of a patent one must build a house upon the ground, improve and plant the soil and keep a good stock of cattle or hogs. But in their frontier holdings the wealthy men merely erected a little bark hut and turned two or three hogs into the woods by it. Or else they would clear one acre of land and plant a little Indian corn for one year, trusting that this evasion would square them with the letter of the law. By such means, Randolph adds, vast tracts were held, all of 
which had been procured on easy terms and much by means of false certificates of rights. "Which drives away the inhabitants and servants, brought up only to planting, to seek their fortunes in Carolina or other places." 15

Randolph suggested that the evil might be remedied by requiring a strict survey of lands in every county, by demanding all arrears of quit rents, by giving strict orders that in the future no grant should exceed 500 acres. These measures, he believed, would cause I00,000 acres to revert to the Crown, and "invite home those who for want of Land left Virginia." It would encourage other persons to come from neighboring colonies to take up holdings and "mightily increase the number of Planters." This would augment the production of tobacco by many thousands of hogsheads, stimulate trade and industry in England, and aid his Majesty's revenue.

The Board of Trade was deeply impressed. They wrote to Governor Andros explaining to him the substance of Randolph's report and asking what steps should be taken to remedy the evils he had pointed out. "But this seeming to us a matter of very great consequence," they added, "we have not been willing to meddle in it without your advice, which we now desire you to give fully and plainly." But Andros knew full well that it was no easy matter to make the large landowners disgorge. The thing had been attempted by Nicholson several years earlier, when suit was instituted against Colonel Lawrence Smith for arrears of quit rents upon tracts of land which had never been under cultivation. ${ }^{16}$ But before the case came to trial Nicholson had been recalled and it was afterward compounded for a nominal sum. The proceedings had caused great resentment among the powerful clique which centered around the Council of State, and Andros was reluctant to reopen the matter. He knew of no frauds in granting patents of land, he wrote the Board, and could suggest no remedy 
for what was past, "being a matter of Property." He agreed, however, that to limit the size of future patents would tend to "the more regular planting and thicker seating of the frontier lands." 17

Consequently when Francis Nicholson was commissioned as Governor in 1698 , he received strict instructions to advise with the Council and the Assembly upon this matter and to report back to the Board. ${ }^{18}$ That nothing was accomplished, however, may clearly be inferred from a letter of a certain George Larkin written December 22, I7OI. "There is no encouragement for anyone to come to the Plantation," he declared, "most of the land lying at all convenient being taken up. Some have $20,000,30,000$ or 40,000 acres, the greater part of which is unimployed." 19 Two years later Nicholson himself wrote that certain recent grants were for ten or twenty thousand acres each, so that privileged persons had engrossed all the good land in those parts, by which means they kept others from settling it or else made them pay for it. ${ }^{20}$

Despite all the concern which this matter created, it is doubtful whether it was to any appreciable extent responsible for the continued emigration of poor families. The mere granting of patents for large tracts of land could not of itself fix the economic structure of the colony, could not, if all other conditions were favorable, prevent the establishment of small frecholds. Rather than have their fields lie idle while the poor men who should have been cultivating them trooped out of the colony, the rich would gladly have sold them in small parcels at nominal prices. In the first half century after the settlement at Jamestown, as we have seen, such a breakup of extensive holdings into little farms actually occurred. Had similar conditions prevailed in the later period a like development would have followed. But in 1630 or 1650 , when slaves were seldom employed and when tobacco was high, the poor 
man's toil yielded a return so large that he could well afford to purchase a little farm and make himself independent. In I680 or 1700 , in the face of the competition of slave labor, he was almost helpless. Even had he found a bit of unoccupied ground to which he could secure a title, he could not make it yield enough to sustain him and his family. ${ }^{21}$

In 1728 Governor Gooch wrote the Board of Trade that the former belief that large holdings of frontier land had been an impediment to settlement was entirely erroneous. It was his opinion, in fact, that extensive grants made it to the interest of the owners to bring in settlers and so populate the country. In confirmation of this he pointed to the fact that Spotsylvania country, where many large patents had been issued, had filled up more rapidly than Brunswick, where they had been restricted in size. ${ }^{22}$

In the first decade of the new century the emigration out of the tobacco colonies continued without abatement. With another disastrous decline in the price of tobacco following the outbreak of the wars of Charles XII and Louis XIV, so many families moved over the border that the Board of Trade, once more becoming seriously alarmed, questioned the Council as to the causes of the evil and what steps should be taken to remedy it. In their reply the Councillors repeated the old arguments, declaring that the lack of land in Virginia and the immunity of debtors from prosecution in the proprietory colonies were responsible for the movement. But they touched the heart of the matter in their further statement that the great stream of negroes that was pouring into the colony had so increased the size of the tobacco crop that prices had declined and the poor found it difficult to subsist. Not only "servants just free go to North Carolina," they wrote, "but old planters whose farms are worn out.",23

A year later President Jennings stated that the migration 
was continuing and that during the summer of I709 "many entire families" had moved out of the colony. ${ }^{24}$ In fact, although but few indentured servants arrived from England after the first decade of the century, poor whites were still departing for the north or for western Carolina so late as 1730. William Byrd II tells us that in 1728 , when he was running the dividing line between Virginia and North Carolina, he was entertained by a man who "was lately removed, Bag and Baggage from Maryland, thro a strong Antipathy he had to work and paying his Debts." Indeed he thought it a "thorough Aversion to Labor" which made "People file off to North Carolina." ${ }^{25}$

It is impossible to estimate the numbers involved in this movement, but they must have rum into the thousands. For a full half century a large proportion of the white immigrants to Virginia seem to have remained there for a comparatively short time only, then to pass on to other settlements. And the migration to Virginia during these years we know to have comprised not less than thirty or thirty-five thousand persons. In fact, it would seem that this movement out of the older colony must have been a very important factor in the peopling of its neighbors, not only western Carolina and western Maryland, but Delaware and Pennsylvania.

Though many thus fled before the stream of negroes which poured in from Africa, others remained behind to fight for their little plantations. Yet they waged a losing battle. Those who found it possible to purchase slaves, even one or two, could ride upon the black tide, but the others slowly sank beneath it.

During the first half of the Eighteenth century the poor whites sought to offset the cheapness of slave made tobacco by producing themselves only the highest grades. The traders who dealt in the finest Orinoco, which brought the best prices, 
found it not upon the plantations of the wealthy, but of those who tended their plants with their own hands. "I must beg you to remember that the common people make the best," wrote Governor Gooch to the Lords of Trade in $1731 .^{26}$

In fact, the wealthy planter, with his newly acquired gangs of slaves, found it difficult at this time to produce any save the lower grades of tobacco. The African was yet too savage, too untutored in the ways of civilization to be utilized for anything like intensive cultivation. "Though they may plant more in quantity," wrote Gooch, "yet it frequently proves very mean stuff, different from the Tobacco produced from well improved and well tended Grounds." "Yet the rich Man's trash will always damp the Market," he adds, "and spoil the poor Man's good Tobacco which has been carefully managed." ${ }^{2}$ Thus the small farmer made one last desperate effort to save himself by pitting his superior intelligence against the cheapness of slave labor.

But his case was hopeless. As slavery became more and more fixed upon the colony, the negro gradually increased in efficiency. He learned to speak his master's language, brokenly of course, but well enough for all practical purposes. $\mathrm{He}$ was placed under the tutelage of overseers, who taught him the details of his work and saw that he did it. He became a civilized being, thoroughly drilled in the one task required of him, the task of producing tobacco. Thus the rich planter soon found it possible to cultivate successfully the higher grades, and so to drive from his last rampart the white freeholder whose crop was tended by himself alone.

Placed at so great a disadvantage, the poor man, at all times in very difficult circumstances, found it almost impossible to exist whenever conditions in Europe sent the price of tobacco down. In the years from 1706 to I7I4, when the tobacco trade was interrupted by the wars of Charles XII in the Baltic 
region and the protracted struggle known as the War of the Spanish Succession, he was reduced to the utmost extremities.

Virginia and Maryland were learning that a prosperity founded upon one crop which commanded a world market was in unsettled times subject to serious setbacks. It was a long cry from the James and the Potomac to the Baltic ports, yet the welfare of the Virginia and Maryland planters was in no small degree dependent upon the maintenance of peaceful conditions in Poland and Sweden and Russia. A war which seriously curtailed the exportation of English leaf to the northern countries would inevitably react on the price and so bring misfortume to the colonial planters. When called before the Board of Trade to testify as to the decay of the tobacco trade, the manufacturer John Linton declared that the Baltic countries, which formerly had purchased thousands of hogsheads a year, now took comparatively few. "The Russian trade is ruined," he said. ${ }^{28}$

The war against France and Spain, coming at this unfortunate juncture, still further restricted the market, sent prices down to new depths and filled to overflowing the planters' cup of misfortune. "The war has stopped the trade with Spain, France, Flanders and part of the Baltic," Colonel Quary reported in a memorial to the Board of Trade. "which took off yearly 20,000 hogsheads of tobacco. Now our best foreign market is Holland." ${ }^{29}$ The pamphlet entitled The Present State of the Tobacco Plantations in America stated, in 1708, that France and Spain alone had imported 20,000 hogsheads, but that both were now otherwise supplied. "The troubles in Sweden, Poland, Russia, etc., have prevented the usual exportation of great quantities to those ports. Virginia and Maryland have severely felt the loss of such exportation, having so far reduced the planters that for several years past the whole product of their tobacco would hardly clothe the servants that made it.",30 
Their misfortunes were accentuated by the fact that the Dutch took advantage of the European upheavals to gain control of a part of the tobacco trade. Upon the outbreak of the war with Louis XIV, England prohibited the exportation of tobacco either to France or to Spain, but Holland, despite her participation in the struggle, apparently took no such action. On the contrary she strained every nerve to entrench herself in the markets of her ally before peace should once more open the flood gates to Virginia and Maryland tobacco. With this in view the acreage in Holland devoted to the cultivation of the leaf was rapidly extended. "The Dutch are improving and increasing their tobacco plantations," wrote John Linton in I706. "In I 7о I they produced only i 8,000 hogsheads. Last year it was 33,500 hogsheads." Plantations at Nimwegen, Rhenen, Amersfoort and Nijkerk turned out I3,400,000 pounds, while great quantities were raised on the Main, in Higher Germany and in Prussia. ${ }^{31}$

The Dutch mixed their own leaf with that of Virginia and Maryland in the proportion of four to one, subjected it to a process of manufacture and sent it out to all the European markets. $^{32}$ In 1707 a letter to John Linton stated that they had from thirty to forty houses for "making up tobacco in rolls," employing 4,000 men, besides great numbers of women and girls. Their Baltic exports were estimated at 12,350,000 pounds; $2,500,000$ pounds to Norway, I,500,000 to Jutland and Denmark, 4,000,000 to Sweden, 2,350,000 to Lapland, 2,000,000 to Danzig and Königsberg. ${ }^{33}$

With the continuation of the war on the continent Dutch competition became stronger and stronger. In I7I4, when peace was at last in prospect, they seemed thoroughly entrenched in many of the markets formerly supplied by the English. "The planting of tobacco in Holland, Germany, Etc.," it was reported to the Board of Trade, "is increased to 
above four times what it was 20 years ago, and amounts now to as much as is made in both Virginia and Maryland." The tobacco trade, which had formerly produced some $£ 250,000$ in the balance of trade, had declined to about half that figure, exports of manufactured goods to the Chesapeake were rapidly dwindling, the number of ships engaged in carrying tobacco was greatly reduced, the merchants were impoverished, the planters were ruined. ${ }^{34}$

"It is hardly possible to imagine a more miserable spectacle than the poorer sort of inhabitants in this colony," the Council wrote in I7I3, "whose labour in tobacco has not for several years afforded them clothing to shelter them from the violent colds as well as heats to both which this climate is subject in the several seasons. The importation of British and other European commodities by the merchants, whereby the planters were formerly well supplied with clothing, is now in a manner wholly left off and the small supplies still ventured sold at such prodigeous rates as they please. Many families formerly well clothed and their houses well furnished are now reduced to rags and all the visible marks of poverty.",35

This unfortunate period was but temporary. With the conclusion of peace English tobacco was dumped upon the European market at a figure so low as to defy competition. And when once the hogsheads began to move, the reaction on Virginia and Maryland was rapid and pronounced. Soon prices rose again to the old levels, and the colony entered upon a period, for the larger planters at least, of unprecedented prosperity. $^{36}$ But the eight years of hardship and poverty made a lasting imprint upon the poorest class of whites. Coming as they did upon the heels of the first great wave of negro fimmigration, they accelerated the movement of the disrupting forces already at work. It was not by accident that the largest migration of whites to other settlements occurred just at this 
time and that the inquiries as to its cause are most frequent. The little planter class never fully recovered from the blow dealt it by the temporary loss of the larger part of the European tobacco trade.

The small freeholders who possessed neither servants nor slaves did not disappear entirely, but they gradually declined in numbers and sank into abject poverty. During the period of Spotswood's adninistration they still constituted a large part of the population. The tax list for 1716 in Lancaster, one of the older counties, shows that of 3 I 4 persons listed as tithables, 202 paid for themselves only ${ }^{37}$ Making ample deductions for persons not owning land it would appear that more than half the planters at this date still tilled their fields only with their own labor. At the time of the American Revolution, however, the situation had changed materially, and a decided dwindling of the poor farmer class is noticeable. In Gloucester county the tax lists for I 782-83 show 490 white families, of which 320 were in possession of slaves. Of the I 70 heads of families who possessed no negroes, since no doubt some were overseers, some artisans, some professional men, it is probable that not more than eighty or ninety were proprietors. $^{38}$ In Spotsylvania county similar conditions are noted. Of 704 tithable whites listed in 1783 all save 199 possessed slaves. $^{39}$ In Dinwiddie county, in the year 1782 , of 843 tithable whites, 2 Io only were not slave holders. ${ }^{40}$ Apparently the Virginia yeoman, the sturdy, independent farmer of the Seventeenth century, who tilled his little holding with his own hands, had become an insignificant factor in the life of the colony. The glorious promises which the country had held out to him in the first fifty years of its existence had been belied. The Virginia which had formerly been so largely the land of the little farmer, had become the land of masters and slaves. For aught else there was no room. 
Before the end of the Eighteenth century the condition of the poorest class had become pitiable. The French philosopher Chastellux who spent much time in Virginia during the American Revolution testifies to their extreme misery. "It is there that I saw poor persons for the first time since crossing the ocean," he says. "In truth, near these rich plantations, in which the negro alone is unhappy, are ofter found miserable huts inhabited by whites whose wan faces and ragged garments give testimony to their poverty."

Philip Fithian, in his Journal, describes the habits of this class and is vigorous in his condemnation of the brutal fights which were so common among them. "In my opinion animals which seek after and relish such odius and filthy amusements are not of the human species," he says, "they are destitute of the remotest pretension of humanity." 42 Even the negroes of the wealthy regarded these persons with contempt, a contempt which they were at no pains to conceal.

The traveller Smyth thought them "kind, hospitable and generous," but illiberal, noisy and rude," and much "addicted to inebriety and averse to labor." This class, he says, "who ever compose the bulk of mankind, are in Virginia more few in numbers, in proportion to the rest of the inhabitants, than perhaps in any other country in the universe." ${ }^{43}$

But it must not be imagined that slavery drove out or ruined the entire class of small farmers, leaving Virginia alone to the wealthy. In fact, most of those who were firmly established remained, finding their salvation in themselves purchasing slaves. Few indeed had been able to avail themselves of the labor of indentured servants; the cost of transportation was too heavy, the term too short, the chances of sickness or desertion too great. But with the influx of thousands of negroes, the more enterprising and industrious of the poor planters quite frequently made purchases. Although the initial outlay 
was greater, they could secure credit by pledging their farms and their crops, and in the end the investment usually paid handsome dividends and many who could not raise the noney to buy a full grown negro, often found it possible to secure a child, which in time would become a valuable asset.

This movement may readily be traced by an examination of the tax lists and county records of the Eighteenth century. In Lancaster even so early as I7I6 we find that the bulk of the slaves were in the hands, not of wealthy proprietors, but of comparatively poor persons. Of the 3 I 4 taxpayers listed, I 3 paid for themselves alone, 94 for two only, 37 for three, 22 for four, thirteen for five, while thirty-five paid for more than five. As there were but few servants in the colony at this time it may be taken for granted that the larger part of the tithables paid for by others were negro slaves. It would seem, then, that of some 200 slave owners in this country, about 165 possessed from one to four negroes only. There were but four persons listed as having more than twenty slaves, William Ball with 22, Madam Fox with 23, William Fox with 25 and Robert Carter with $126 .{ }^{44}$

Nor did the class of little slave holders melt away as time passed. In fact they continued to constitute the bulk of the white population of Virginia for a century and a half, from the beginning of the Eighteenth century until the conquest of the State by Federal troops in 1865 . Thus we find that of 633 slave owners in Dinwiddie county in 1782,95 had one only, 66 had two, 71 three, 45 four, 50 five, making an aggregate of 327 , or more than half of all the slave holders, who possessed from one to five negroes. ${ }^{45}$ In Spotsylvania there were, in 1783,505 slave owners, of whom 78 possessed one each, 54 two, 44 three, $4 \mathrm{I}$ four, and 30 five each. Thus 247 , or nearly 49 per cent of the slave holders, had from one to five slaves only. One hundred and sixteen, or 23 per cent, had 
from six to ten inclusive. ${ }^{40}$ The Gloucester lists for 1783 show similar conditions. There were in this country 320 slave holders, having 3,314 negroes, an average of about $101 / 3$ for each owner. Fifty had one each, 4I had two each, 9 had three, 30 had four and twenty-six had five. Thus ${ }_{5} 6$, or about half of all the owners, had from one to five slaves. ${ }^{47}$ In Princess Anne county, of a total of 388 slave owners, Ioo had one each, $5^{6}$ had two each and forty-five had three each. ${ }^{48}$

Records of transfers of land tend to substantiate this testimony, by showing that the average holdings at all times in the Eighteenth century were comparatively small. In the years from I722 to I 729 Spotsylvania was a new county, just opened to settlers, and a large part of its area had been granted in large tracts to wealthy patentees. Yet the deed book for these years shows that it was actually settled, not by these men themselves, but by a large number of poor planters. Of the 197 transfers of land recorded, 44 were for roo acres or less and I 10 for 300 acres or less. The average deed was for 487 acres. As some of the transfers were obviously made for speculative purposes and not with the intent of putting the land under cultivation, even this figure is misleading. The average farm during the period was probably not in excess of 400 acres. One of the most extensive dealers in land in Spotsylvania was Larkin Chew who secured a patent for a large tract and later broke it up into many small holdings which were sold to new settlers. ${ }^{49}$

This substitution of the small slave holder for the man who used only his own labor in the cultivation of his land unquestionably saved the class of small proprietors from destruction. Without it all would have been compelled to give up their holdings in order to seek their fortunes elsewhere, or sink to the condition of "poor white trash." Yet the movement was in many ways unfortunate. It made the poor man less in- 
dustrious and thrifty. Formerly he had known that he could win nothing except by the sweat of his brow, but now he was inclined to let the negro do the work. Slavery cast a stigma upon labor which proved almost as harmful to the poor white man as did negro competition. Work in the tobacco fields was recognized as distinctly the task of an inferior race, a task not in keeping with the dignity of freemen.

Jefferson states that few indeed of the slave owners were ever seen to work. "For in a warm climate," he adds, "no man will labour for himself who can make another labour for him." ${ }_{50}$ Chastellux noted the same tendency, declaring "that the indolence and dissipation of the middling and lower classes of white inhabitants of Virginia is such as to give pain to every reflecting mind." 51

Slavery developed in the small farmers a spirit of pride and haughtiness that was unknown to them in the Seventeenth century. Every man, no matter how poor, was surrounded by those to whom he felt himself superior, and this gave him a certain self-esteem. Smyth spoke of the middle class as generous, friendly and hospitable in the extreme, but possessing a rudeness and haughtiness which was the result of their "general intercourse with slaves." 52 Beverley described them as haughty and jealous of their liberties, and so impatient of restraint that they could hardly bear the thought of being controlled by any superior power. Hugh Jones, Anbury, Fithian and other Eighteenth century writers all confirm this testimony.

Despite the persistence of the small slave holder it is obvious that there were certain forces at work tending to increase the number of well-to-do and wealthy planters. Now that the labor problem, which in the Seventeenth century had proved so perplexing, had finally been solved, there was no limit to the riches that might be acquired by business acumen, 
industry and good management. And as in the modern industrial world the large corporation has many advantages over the smaller firms, so in colonial Virginia the most economical way of producing tobacco was upon the large plantations.

The wealthy man had the advantage of buying and selling in bulk, he enjoyed excellent credit and could thus often afford to withhold his crop from the market when prices were momentarily unfavorable, he could secure the best agricultural instruments. Most important of all, however, was the fact that he could utilize the resources of his plantation for the production of crude manufactured supplies, thus to a certain extent freeing himself from dependence upon Birtish imports and keeping his slaves at work during all seasons of the year. Before the Eighteenth century had reached its fifth decade every large plantation had become to a remarkable degree selfsustaining. Each numbered among its working force various kinds of mechanics-coopers, blacksmiths, tanners, carpenters, shoemakers, distillers. These men could be set to work whenever the claims of the tobacco crop upon their time were not imperative producing many of the coarser articles required upon the plantation, articles which the poor farmer had to import from England. For this work white men were at first almost universally made use of, but in time their places were taken by slaves. "Several of them are taught to be sawyers, carpenters, smiths, coopers, \&c.," says the historian Hugh Jones, "though for the most part they be none of the aptest or nicest." 53

The carpenter was kept busy constructing barns and servants' quarters, or repairing stables, fences, gates and wagons. The blacksmith was called upon to shoe horses, to keep in order ploughs, hinges, sickles, saws, perhaps even to forge outright such rough iron ware as nails, chains and hoes. The 
cooper made casks in which to ship the tobacco crop, barrels for flour and vats for brandy and cider. The tanner prepared leather for the plantation and the cobbler fashioned it into shoes for the slaves. Sometimes there were spinners, weavers and knitters who made coarse cloth both for clothing and for bedding. The distiller every season made an abundant supply of cider, as well as apple, peach and persimmon brandy.

And the plantation itself provided the materials for this varied manufacture. The woods of pine, chestnut and oak yielded timber for houses and fuel for the smithy. The herd of cattle supplied hides for the tanner. The cloth makers got cotton, flax and hemp from the planter's own fields, and wool from his sheep. His orchard furnished apples, grapes, peaches in quantities ample for all the needs of the distiller. In other words, the large planter could utilize advantageously the resources at hand in a manner impossible for his neighbor who could boast of but a small farm and half a score of slaves. ${ }^{54}$

It was inevitable, then, that the widespread use of slave labor would result in the gradual multiplication of well-to-do and wealthy men. In the Seventeenth century not one planter in fifty could be classed as a man of wealth, and even so late as 1704 the number of the well-to-do was very narrowly limited. In a report to the Lords of Trade written in that year Colonel Quary stated that upon each of the four great rivers of Virginia there resided from "ten to thirty men who by trade and industry had gotten very competent estates." ${ }_{55}$ Fifty years later the number had multiplied several times over.

Thus in Gloucester county in 1783 , of 320 slave holders no less than 57 had sixteen or more. Of these one possessed 162 , one 138 , one 93 , one 86 , one 63 , one 58 , two 57 , one 56 , one 43 and one $40 .^{56}$ In Spotsylvania, of 505 owners, 76 had sixteen or more. Of these Mann Page, Esq., had 157, Mrs. Mary Daingerfield had 7I, William Daingerfield 6r, Alexander 
Spotswood 60, IVilliam Jackson 49, George Stubblefield 42, Frances Marewither 40 , William Jones $39 .{ }^{57}$

The Dinwiddie tax lists for 1783 show that of 633 slave holders, no less than 60 had twenty-one or more negroes. Among the more important of these were Robert Turnbull with 8I, Colonel John Banister with 88, Colonel William Diggs with 72, John Jones with 69, Mrs. Mary Bolling with 5I, Robert Walker with 52, Winfield Mason with 40, John Burwell with 42, Gray Briggs with 43, William Yates with 55, Richard Taliaferro with 43, Major Thomas Scott with 57 , Francis Muir with $47 .^{58}$ The wealth of the larger planters is also shown by the large number of coaches recorded in these lists, which including phaetons, chariots and chairs, aggregated I 80 wheels.

Thus it was that the doors of opportunity opened wide to the enterprising and industrious of the middle class, and many availed themselves of it to acquire both wealth and influence. Smyth tells us that at the close of the colonial period there were many planters whose fortunes were "superior to some of the first rank," but whose families were "not so ancient nor respectable." ${ }^{59}$ It was the observation of Anbury that gentlemen of good estates were more numerous in Virginia than in any other province of America. ${ }^{60}$

In fact the Eighteenth century was the golden age of the Virginia slave holders. It was then that they built the handsome homes once so numerous in the older counties, many of which still remain as interesting monuments of former days; it was then that they surrounded themselves with graceful furniture and costly silverware, in large part imported from Great Britain; it was then that they collected paintings and filled their libraries with the works of standard writers; it was then that they purchased coaches and berlins; it was 
then that men and women alike wore rich and expensive clothing.

This movement tended to widen the influence of the aristocracy and at the same time to eliminate any sharp line of demarkation between it and the small slave holders. There was now only a gradual descent from the wealthiest to the poor man who had but one slave. The Spotsylvania tax lists for I 783 show 247 slaveholders owning from one to five negroes, I 16 owning from six to ten inclusive, 66 owning from eleven to fifteen inclusive, and seventy-six owning more than fifteen. ${ }^{61}$ In Gloucester ${ }^{5} 6$ had from one to five slaves, 66 from five to ten inclusive, $4 \mathrm{I}$ from eleven to fifteen inclusive, and fifty-seven over fifteen. Thus in a very true sense the old servant holding aristocracy had given way to a vastly larger slave holding aristocracy.

It is this fact which explains the decline in power and influence of the Council in Virginia, which was so notable in the Eighteenth century. This body had formerly been representative of a small clique of families so distinct from the other planters and possessed of such power in the government as to rival the nobility of England itself. Now, however, as this distinction disappeared, the Council sank in prestige because it represented nothing, while the House of Burgesses became the mouthpiece of the entire slave holding class, and thus the real power in the colonial Government.

Historians have often expressed surprise at the small number of Tories in Virginia during the American Revolution. The aristocratic type of society would naturally lead one to suppose that a large proportion of the leading families would have remained loyal to the Crown. Yet with very few exceptions all supported the cause of freedom and independence, even though conscious of the fact that by so doing they were jeopardizing not only the tobacco trade which was the basis 
of their wealth, but the remnants of their social and political privileges in the colony. When the British Ministry tried to wring from the hands of the Assembly the all-important control over taxation which all knew to be the very foundation of colonial self-government, every planter, the largest as well as the smallest, felt himself aggrieved, for this body was the depository of his power and the guardian of his interests. A hundred years before, when the commons rose against the oppression and tyranny of the Government, the wealthy men rallied to the support of Sir William Berkeley and remained loyal to him throughout all his troubles. In 1775 there was no such division of the people; the planters were almost a unit in the defense of rights which all held in common.

It is obvious, then, that slavery worked a profound revolution in the social, economic and political life of the colony. It practically destroyed the Virginia yeomanry, the class of small planters who used neither negroes nor servants in the cultivation of their fields, the class which produced the bulk of the tobacco during the Seventeenth century and constituted the chief strength of the colony. Some it drove into exile, either to the remote frontiers or to other colonies; some it reduced to extreme poverty; some it caused to purchase slaves and so at one step to enter the exclusive class of those who had others to labor for them. Thus it transformed Virginia from a land of hardworking, independent peasants, to a land of slaves and slave holders. The small freeholder was not destroyed, as was his prototype of ancient Rome, but he was subjected to a change which was by no means fortunate or wholesome. The wealthy class, which had formerly consisted of a narrow clique closely knit together by family ties. was transformed into a numerous body, while all sharp line of demarkation between it and the poorer slave holders was wiped out. In short, the Virginia of the Eighteenth century, the 
Virginia of Gooch and Dinwiddie and Washington and Jefferson, was fundamentally different from the Virginia of the Seventeenth century, the Virginia of Sir William Berkeley and Nathaniel Bacon. Slavery had wrought within the borders of the Old Dominion a profound and far reaching revolution. 


\section{NOTES TO CHAPTER I}

${ }^{1}$ Peter Force, Tracts and Other Papers, Vol. III, A True Declaration, p. 25.

2 Purchas, Vol. XVIII, pp. 437-438.

${ }^{3}$ Peter Force, Tracts and Other Papers, Vol. III, A True Declaration, p. 23.

${ }^{4}$ Alexander Brown, The Genesis of the United States, Vol. I, p. 37 .

${ }^{5}$ Peter Force, Tracts and Other Papers, Vol. I, Nova Brittania, pp. $2 \mathrm{I}-22$.

${ }^{6}$ Hakluyt, Discourse, pp. 89-90.

'Hakluyt, Discourse, p. 105.

${ }^{8}$ Hakluyt, Discourse, p. $3 \mathrm{I}$.

${ }^{9}$ Hakluyt, Discourse, pp. I4-I 5.

${ }^{10}$ Alexander Brown, The First Republic in America, p. 49.

${ }^{11}$ Alexander Brown, The Genesis of the United States, Vol. I. p. 349; Peter Force, Tracts and Other Papers, Vol. I, Nova Brittania, pp. I6-I7.

${ }^{12}$ Alexander Brown, The Genesis of the United States, Vol. I, p. 239.

${ }^{13}$ Alexander Brown, The Genesis of the United States, Vol. I, p. 202.

${ }^{14}$ P. A. Bruce, Economic History of Virginia, Vol. II, p. 445.

${ }^{15}$ Neill, The Virginia Company of London, p. 338.

${ }^{16}$ Randolph Manuscript, p. 2I2.

${ }^{17}$ P. A. Bruce, Economic History of Virginia, Vol. II, p. 440; Alexander Brown, The Genesis of the United States, Vol. I, p. 239.

${ }_{18}$ P. A. Bruce, Economic History of Virginia, Vol. II, p. 44I.

${ }^{19}$ P. A. Bruce, Economic History of Virginia, Vol. II, p. 443.

\section{NOTES TO CHAPTER II}

${ }^{1}$ P. A. Bruce, Economic History of Virginia, Vol. I, p. I6I; Alexander Brown, The First Republic in America, p. 232.

${ }^{2}$ William Strachey. Historie of Travaile into Virginia Britannia, p. I2I; P. A. Bruce, Economic History of Virginia, Vol. I, p. 162. 
${ }^{3}$ Ralph Hamor, True Discourse, pp. 24, 34.

${ }^{4}$ G. L. Beer, The Origins of the British Colonial System, 1. 79.

${ }^{5}$ Edward Arber, The Works of Captain John Smith, p. 535.

${ }^{6}$ Alexander Brown, The First Republic in America, p. 268.

${ }^{7}$ G. L. Beer, The Origins of the British Colonial System, ip. 87.

${ }^{8}$ G. L. Beer, The Origins of the British Colonial System, p. 81.

${ }^{9}$ Alexander Brown, The First Republic in America, p. 268.

${ }^{10}$ Virginia Magazine of History and Biography, Vol. IX, pp. 40-4I.

${ }^{11}$ Virginia Magazine of History and Biography, Vol. IX, pp. $176-177$.

${ }_{12}$ P. A. Bruce, Economic History of Virginia, Vol. II, p. 416.

${ }^{13}$ Alexander Brown, The Genesis of the United States, Vol. I, pp. $355-356$.

${ }_{14}$ The lack of towns in Virginia was a source of great regret to the English Government, and more than once attempts were made to create them by artificial means.

${ }^{15}$ Even at the end of the Seventeenth century the average price for land in the older counties was about thirty pounds of tobacco an acre.

${ }^{16}$ P. A. Bruce, Economic History of Virginia, Vol. I, p. 578; Vol. II, p. 48.

${ }^{17}$ It was Chanco, an Indian boy living with a Mr. Pace, who revealed the plot to massacre the whites in I622, and so saved the colony from destruction. Edward Arber, The Works of Captain John Smith, p. 578.

${ }^{18} \mathrm{P}$. A. Bruce, The Economic History of Virginia, Vol. II, p. 70 .

${ }^{19}$ For a full discussion of this matter see p.

${ }^{20}$ Hakluyt, Vol. VII, p. 286.

${ }^{21}$ P. A. Bruce, Economic History of Virginia, Vol. I, p. $5^{82 .}$

${ }^{22}$ Abstracts of Proceedings of Virginia Company of London, Vol. I, pp. 28, I72; Edward Arber, The Works of Captain John Smith, p. 609.

${ }^{23}$ Hening, Statutes at Large, Vol. II, p. 5 Io.

${ }^{24}$ P. A. Bruce, Economic History of Virginia, Vol. I. p. 603.

${ }^{25}$ P. A. Bruce, Economic History of Virginia, Vol. I, p. 605.

${ }^{26}$ Virginia Land Patents, Vol. V, Register of Land Office, Virginia State Capitol.

${ }^{27}$ Hening, Statutes at Large, Vol. II, p. 5 Io.

${ }^{28}$ P. A. Bruce, Economic History of Virginia, Vol. I, p. 6I I. 
${ }^{29}$ British Public Record Office, COI-26-77, Berkeley to the Board of Trade.

${ }^{30}$ Peter Force, Tracts and Other Papers, Vol. III, Orders and Constitutions, I6I9, I620, p. 22.

${ }^{31}$ Virginia Land Patents, Register of Land Office, Virginia State Capitol.

${ }^{32}$ Calendar of State Papers, Colonial Series, I574-I660, p. 208.

${ }^{33}$ Princeton Transcripts, Virginia Land Patents, Princeton University Library.

${ }^{34}$ Virginia Land Patents, Register of Land Office, Virginia State Capitol.

\section{NOTES TO CHAPTER III}

${ }^{1}$ L. G. Tyler, Narratives of Early Virginia, pp. 2I-22.

${ }^{2}$ Abstracts of Proceedings of Virginia Company of London, Vol. II, p. I7I.

${ }^{3}$ British Public Record Office, COI-26-77, Berkeley to Board of Trade.

${ }^{4}$ Hening, Statutes at Large, Vol. I, p. 257.

${ }^{5}$ Hening, Statutes at Large, Vol. I, p. 4I I.

${ }^{6}$ Hening, Statutes at Large, Vol. I, p. 539.

${ }^{7}$ British Public Record Office, COr-26-77, Berkeley to Board of Trade.

${ }^{8}$ Virginia Land Patents, Register of Land Office, Virginia State Capitol.

${ }^{9}$ P. A. Bruce, Economic History of Virginia, Vol. I, p. 595.

${ }^{10} \mathrm{~J}$. C. Hotten, Original Lists of Emigrants to America (I600I700).

${ }^{11}$ Peter Force, 'Tracts and Other Papers, Vol. II, New Description of Virginia, p. 3.

${ }^{12}$ British Public Record Office, COI-26-77, Berkeley to Board of Trade.

${ }^{13}$ British Public Record Office, CO5-I359, p. I 19, Colonial Entry Book, Governor Andros to the Lords of Trade.

${ }^{14}$ E. D. Neill, Virginia Vetusta, p. I23.

${ }^{15}$ Hugh Jones, Present State of Virginia, p. 6I.

${ }^{16}$ Surry County Records, I684-1686, Virginia State Library.

${ }^{17}$ York County Records, I696-170I, Virginia State Library.

${ }^{18}$ Rappahannock County Deeds, I680-I688, Virginia State Library.

${ }^{10}$ Essex County, Orders, Deeds, Etc., I692-I695, Virginia State Library. 
${ }^{20} \mathrm{~J}$. C. Hotten, Original Lists of Emigrants to America, pp. 266-275.

${ }^{21}$ P. A. Bruce, Economic History of Virginia, Vol. I, pp. 529532.

${ }^{22}$ Virginia Land Patents, Register of Land Office, Virginia State Capitol.

${ }^{23}$ Virginia Magazine of History and Biography, Vol. I, p. 30.

${ }^{24}$ Virginia Magazine of History and Biography, Vol. XII, p. 387.

${ }_{25}^{25}$ Virginia Land Patents, Register of Land Office, Virginia State Capitol.

${ }^{26}$ Virginia Land Patents, Register of Land Office, Virginia State Capitol.

${ }^{27}$ Essex County, Orders, Deeds, Etc., 1692-1695, Virginia State Library.

${ }^{28}$ Surry County Records, I645-1672, p. I7.

${ }^{29}$ Essex County, Orders, Deeds, Etc., I692-1695, p. 348, Virginia State Library.

${ }^{30}$ Virginia Land Patents, Register of Land Office, Virginia State Capitol, Vol. V.

${ }^{31}$ Essex County, Orders, Deeds, Etc., 1692-1695, pp. 199, 202, 205, 209, 216, 348, 394, 407, 4I3, Virginia State Library.

${ }^{32} \mathrm{H}$. R. McIlwaine, Journals of the House of Burgesses, I686, p. 37 .

${ }^{33}$ British Public Record Office, CO5-I359, pp. 9I-92, Colonial Entry Book.

${ }^{34}$ British Public Record Office, CO5-1306, Document 116, Correspondence of the Board of Trade.

${ }^{35}$ British Public Record Office, CO5-1355, p. 361, Colonial Entry Book.

${ }^{36}$ British Public Record Office, CO5-1359, pp. 9I-92, Colonial Entry Book.

${ }^{37}$ British Public Record Office, CO5-1405, p. 460, Council Minutes, I680-1695.

${ }^{38}$ British Public Record Office, CO5-I 405, pp. 544-545, Council Minutes, I680-I695.

${ }^{39}$ British Public Record Office, $\mathrm{CO}^{-1359,}$ p. 345, Colonial Entry Book, I696-1700.

${ }^{40}$ British Public Record Office, CO5-I339, Document $33 \mathrm{~V}$. Correspondence of the Board of Trade.

${ }^{41}$ British Public Record Office, CO5-I3I4, Document 63VIII, Correspondence of the Board of Trade. A copy of this interest- 
ing document is published as an appendix to this volume.

${ }^{42}$ See appendix.

${ }^{43}$ See appendix.

44 Of this land I 5 acres belonged to Thomas Jefferson, probably the grandfather of President Jefferson.

${ }^{45}$ In the opening years of the Eighteenth century the increased importation of slaves brought about an immediate decline in the migration of whites to Virginia from England.

${ }^{46}$ Hening, Statutes at Large, Vol. II, p. 480. The laws governing the tithables were altered slightly from time to time.

${ }^{47}$ Surry County, Wills, Deeds, Etc., I67I-I684, pp. I34-I38, Virginia State Library.

${ }^{48}$ Surry County, Wills, Deeds, Etc., I67I-I684, pp. 134-138, Virginia State Library.

${ }^{49}$ Surry County, Deeds, Wills, Etc., I684-1686, pp. 59-63, Virginia State Library.

${ }^{50}$ Virginia Magazine of History and Biography, Vol. I, pp. 364-373.

${ }^{51}$ Prince George county was formed out of Charles City in I703.

${ }^{52}$ Surry County, Wills, Deeds, Etc., I67I-I684; Surry County, Deeds, Wills, Etc., I684-I686, Virginia State Library.

${ }^{53}$ Elizabeth City County Records, I684-I699, Virginia State Library.

\section{NOTES TO CHAPTER IV}

${ }^{1}$ William and Mary Quarterly, Vol. VIII, p. 273.

${ }^{2}$ William and Mary Quarterly, Vol. VIII, p. 273.

${ }^{3}$ P. A. Bruce, Economic History of Virginia, Vol. II, p. 42.

${ }^{4}$ Robert Beverley, History of Virginia, p. 221.

${ }^{5}$ Peter Force, Tracts and Other Papers, Vol. III, Leah and Rachel, p. II.

${ }^{\circ}$ William and Mary Quarterly, Vol. XXVI, p. 31 .

${ }^{7}$ Peter Force, Tracts and Other Papers, Vol. III, Leah and Rachel, p. II.

${ }^{8}$ In fact, it was stated by John Hammond in 1656 that many servants acquired considerable property even before the expiration of their indentures. "Those servants that will be industrious may in their time of service gain a competent estate before their Freedomes," he says, "which is usually done by many, and they gaine esteeme and assistance that appear so industrious: 
There is no master almost but will allow his Servant a parcell of clear ground to plant some tobacco in for himselfe, which he may husband at those many idle times he hath allowed him and not prejudice, but rejoyce his Master to see it, which in time of Shipping he may lay out for commodities, and in Summer sell them again with advantage, and get a Sow-Pig or two, which any body almost will give him, and his Master suffer him to keep them with his own, which will be no charge to his Master, and with one year's increase of them may purchase a Cow calf or two, and by that time he is for himself; he may have Cattle, Hogs and Tobacco of his own, and come to live gallantly; but this must be gained (as I said) by Industry and affability, not by sloth nor churlish behaviour." Peter Force, Tracts and Other Papers, Vol. III, Leah and Rachel, p. I4.

${ }^{9}$ Virginia Magazine of History and Biography, Vol. IV, p. 157.

${ }_{10}$ Virginia Magazine of History and Biography, Vol. VII, p. 262.

${ }^{11}$ Virginia Magazine of History and Biography, Vol. VII, p. 26 I.

${ }^{12}$ R. L. Beer, Origins of the British Colonial System, p. 154. 160

${ }^{13}$ Virginia Magazine of History and Biography, Vol. VIII, p.

${ }^{14}$ Virginia Magazine of History and Biography, Vol. XIII, p. $38 \mathrm{I}$

${ }^{15}$ Peter Force, Tracts and Other Papers, Vol. II, New Description of Virginia, pp. 4-6.

${ }^{16}$ British Public Record Office, COr-2I, Secretary Ludwell to Lord John Berkeley.

${ }^{17}$ Alexander Brown, The First Republic in America, p. 268.

${ }^{18}$ Virginia Magazine of History and Biography, Vol. VII, p. 267, King Charles I to the Governor and Council of Virginia.

${ }^{19}$ Virginia Magazine of History and Biography, Vol. I, p. 293. ${ }^{20}$ Virginia Magazine of History and Biography, Vol. VI, p. 376. ${ }^{21}$ Virginia Magazine of History and Biography, Vol. II, p. 53. ${ }^{22}$ Virginia Magazine of History and Biography, Vol. II, p. 394. ${ }^{23}$ Virginia Magazine of History and Biography, Vol. VI, p. 260. ${ }^{24}$ Virginia Magazine of History and Biography, Vol. VII, p. 382.

${ }^{25}$ Virginia Magazine of History and Biography, Vol. VIII, p. I 49. 
${ }^{26}$ Governor Yeardley's Instructions of 1626 contain the statement that "tobacco falleth every day more and more to a baser price."

${ }^{27}$ Virginia Magazine of History and Biography, Vol. VII, p. 376 .

${ }^{28}$ Virginia Magazine of History and Biography, Vol. VIII, p. 159 .

${ }^{29}$ Virginia Magazine of History and Biography, Vol. IX, p. 177 .

${ }^{30}$ Virginia Magazine of History and Biography, Vol. X, p. 425.

${ }^{31}$ G. L. Beer, Origins of the British Colonial System, p. I 59.

${ }^{32}$ Peter Force, Tracts and Other Papers, Vol. II, New Description of Virginia, p. 4.

${ }^{33}$ Virginia Magazine of History and Biography, Vol. VIII, p. 150 .

${ }^{34}$ Virginia Magazine of History and Biography, Vol. II, p. 288. In Feb. I627, orders were issued once more that all colonial tobacco, whether of Virginia or of the West Indies, should be shipped only to London. Calendar of State Papers, 1574-1660, p. 84 .

${ }^{35}$ Virginia Magazine of History and Biography, Vol. VIII, pp. I 49, I 55 .

${ }^{36}$ British Public Record Office, COI-I2, Petition of Jan. 2, 1655 .

${ }_{37}$ P. A. Bruce, Economic History of Virginia, Vol. I, pp. 349356.

${ }^{38}$ G. L. Beer, Origins of the British Colonial System, pp. 203204.

${ }^{39}$ G. L. Beer, Origins of the British Colonial System, p. 2 I6.

${ }^{40}$ The author of A New Description of Virginia, published in I649, states that "in Tobacco they can make L2o sterling a man, at $3 \mathrm{~d}$ a pound per annum." Peter Force, Tracts and Other Papers, Vol. II, New Description of Virginia, p. 6.

${ }^{41}$ Virginia Magazine of History and Biography, Vol. VII, p. 382.

${ }^{42}$ Virginia Magazine of History and Biography, Vol. VIII, p. I49, Vol. II, p. 53, Vol. VII, p. 259. 260.

${ }_{43}$ Virginia Magazine of History and Biography, Vol. VII, p.

${ }^{44}$ Virginia Magazine of History and Biography, Vol. VIII, p. I 58 . 
${ }^{45}$ Abstracts of Proceedings of Virginia Company of London, Vol. I, pp. 4I-42.

${ }^{46} \mathrm{~J}$. C. Hotten, Original Lists of Emigrants to America, pp. $20 \mathrm{r}-265$.

${ }^{47}$ Colonial Virginia Register, pp. 54-55.

${ }_{48}$ Peter Force, Tracts and Other Papers, Vol. III, p. I6.

${ }^{49}$ Colonial Virginia Register, pp. 68-69.

${ }^{50}$ Virginia Land Patents, Register of Land Office, Virginia State Capitol.

51 Virginia Magazine of History and Biography, Vol. II, p. 420.

${ }^{52}$ Virginia Magazine of History and Biography, Vol. II, p. 42I; Vol. IV, p. 75.

${ }^{53}$ Virginia Magazine of History and Biography, Vol. I, p. 77.

${ }^{54}$ W. A. Crozier, Virginia County Records, Vol. VI, pp. I5-I8.

${ }^{55}$ W. A. Crozier, Virginia County Records, Vol. VI, p. 56.

${ }^{56}$ Virginia Land Patents, Register of Land Office, Virginia State Capitol.

${ }^{57}$ William and Mary Quarterly, Vol. XI, p. 27 I.

${ }^{58}$ William and Mary Quarterly, Vol. XI, p. 276.

${ }^{59}$ William and Mary Quarterly, Vol. XI, pp. 27I-276.

${ }^{60}$ Virginia Colonial Register, pp. 64, 68, 70.

${ }^{61}$ William and Mary Quarterly, Vol. IX, p. 72.

${ }^{62}$ Virginia Land Patents, Vol. V, p. 224, Register of Land Office, Virginia State Capitol.

${ }^{63}$ W. A. Crozier, Virginia County Records, New Series Vol. I, p. 4.

${ }^{64} \mathrm{~W}$. A. Crozier, Virginia County Records, Vol. VI, pp. 83 , 84, I25, I 26.

${ }^{65}$ W. A. Crozier, Virginia County Records, Vol. VII, p. 5.

${ }^{66} \mathrm{~W}$. A. Crozier, Virginia County Records, Vol. VI, p. 78.

${ }^{67}$ W. A. Crozier, Virginia County Records, Vol. VI, pp. 77, I9I, 28I.

${ }^{68}$ W. A. Crozier, Virginia County Records, Vol. VI, p. 122.

${ }^{69}$ W. A. Crozier, Virginia County Records, Vol. VI, p. 192.

${ }^{70}$ W. A. Crozier, Virginia County Records, Vol. VI, p. 76.

${ }^{71}$ William and Mary Quarterly, Vol. IX, p. I44.

${ }^{72}$ William and Mary Quarterly, Vol. IX, p. I44.

${ }^{73}$ William and Mary Quarterly, Vol. XI, p. 276.

${ }^{74}$ Virginia Land Patents, Vol. III, Register of Land Office, Virginia State Capitol. The name is here spelled John Blackborne.

${ }^{75}$ Virginia Land Patents, Vol. III, Register of Land Office, 
Virginia State Capitol. On the lists the name is spelled William Butcher.

${ }^{76}$ J. C. Wise, The Early History of the Eastern Shore of Virginia, pp. $135^{-1} 37$.

iT Virginia Land Patents, Vol. IV, Register of Land Office, Virginia State Capitol.

${ }^{75} \mathrm{~J}$. C. Wise, The Early History of the Eastern Shore of Virginia, p. 95 .

${ }^{79}$ G. C. Greer, Early Virginia Immigrants, p. 68.

${ }^{80}$ J. C. Wise, The Early History of the Eastern Shore of Virginia, p. 376.

s1 Virginia Magazine of History and Biography, Vol. V, p. 1or.

8: IV. A. Crozier, Virginia County Records, Vol. VII, p. 177.

${ }^{83}$ Virginia Magazine of History and Biography, Vol. VI, p. 92.

${ }^{84}$ Virginia Magazine of History and Biography, Vol. VI, p. 298.

${ }^{85}$ In 1656 John Hanmond declared that though it cost six pounds sterling to go to Virginia, those who decided to make the venture could be sure that their money was well spent. He advised "any that goes over free, but in a mean condition, to hire himself for reasonable wages of Tobacco and Provision, the first year," for by that means he could live free of disbursement, and "have something to help him the next year." Peter Force, Tracts and Other Papers, Vol. III, Leah and Rachel, p. I4.

${ }^{86}$ Virginia Magazine of History and Biography, Vol. VIII, p. $44 \mathrm{I}$.

${ }^{87}$ Virginia Magazine of History and Biography, Vol. IX, p. 27. ${ }^{8 s}$ Virginia Magazine of History and Biography, Vol. X, p. 271.

\section{NOTES TO CHAPTER V}

${ }^{1}$ G. L. Beer, The Old Colonial System, Vol. II, p. Iog.

${ }^{2}$ British Public Record Office, CO5-I3I5, Document 26, Correspondence of the Board of Trade.

${ }^{3}$ P. A. Bruce, Economic History of Virginia, Vol. I, p. $40 \mathrm{O}$.

${ }^{4}$ R. L. Beer, The Old Colonial System, Vol. I, p. I60.

${ }^{5}$ British Public Record Office, $\mathrm{CO}_{5}^{-1316}$, Perry and Hyde to the Lords of Trade, Correspondence of the Board of Trade.

${ }^{6}$ British Public Record Office, CO5-1316, The Present State of the Tobacco Plantations in America, Correspondence of the Board of Trade.

${ }^{7}$ British Public Record Office, CO5-I316, Correspondence of the Board of Trade; Statutes of the Realm, Vol. IX, p. 917. 
${ }^{8}$ Virginia Magazine of History and Biography, Vol. I, pp. I $4 \mathrm{I}-\mathrm{I} 55$.

${ }^{9}$ British Public Record Office, COr-ı6, Petition of Berkeley and Others, Aug. 26, I662.

${ }^{10}$ British Public Record Office, COI-20, Thomas Ludwell to Secretary Arlington, May I, I666.

${ }^{11}$ British Public Record Office, COI-20, Sir William Berkeley and others to Secretary Arlington, July I 3, I666.

${ }^{12}$ British Public Record Office, COr-20, Sir William Berkeley and others to Secretary Arlington, July I 3, I666.

${ }^{13}$ British Public Record Office, COI-2I, Thomas Ludwell to Lord Arlington, Feb. I2, I667.

${ }^{14}$ British Public Record Office, COI-2I, Thomas Ludwell to Lord John Berkeley.

${ }^{15}$ British Public Record Office, COI-23, p. 19, Ludwell to Lord Arlington.

${ }^{16}$ British Public Record Office, COI-2I, Governor and Council to the King.

${ }^{17}$ British Public Record Office, COI-30, p. 5I, Petition of the Governor and Council.

${ }^{18}$ British Public Record Office, CO5-I356, p. 408, Report of the Council to the King.

${ }^{19}$ British Public Record Office, CO5-I355, p. 385, Colonial Entry Book.

${ }^{20}$ British Public Record Office, COI-23, p. I9, Ludwell to Lord Arlington, July 20, 1665.

${ }^{21}$ British Public Record Office, CO5-I37I, p. 246, Colonial Entry Book.

${ }_{22}$ British Public Record Office, CO5-I37I, pp. 232-240, Dialogue Between John Good and Nathaniel Bacon, Colonial Entry Book, I677.

${ }^{23}$ British Public Record Office, COI-3O, p. 5I, Petition of the Governor and Council to the King, July 1673.

${ }^{24}$ British Public Record Office, CO5-I355, p. 4IO, Colonial Entry Book.

${ }^{25}$ British Public Record Office, CO5-I356, p. I79, Colonial Entry Book.

${ }^{26}$ G. L. Beer, The Old Colonial System, Vol. II, p. 147.

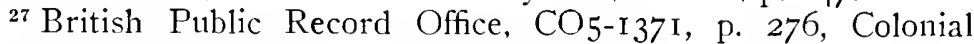
Entry Book.

${ }^{28}$ British Public Record Office, CO5-137I, p. 276, Colonial Entry Book. 
${ }^{29}$ This view of the matter has the support of the dean of Virginia historians, Dr. Philip Alexander Bruce. Dr. Bruce writes: "No less an authority than Robert Beverley, the historian, states that the Navigation Acts had a sensible influence in precipitating Bacon's Rebellion. In the early life of this writer he must have been closely associated with hundreds of people who had been through the uprising, and knew much, by direct observation, of the currents that governed it. The elder Beverley was thoroughly informed and thus, in his own home, the son had the best of opportunities of learning the truth. Beverley himself declared that the Acts were causing discontent among the people, long before the Rebellion actually occurred, and so did John Bland in his memorable petition. There is no doubt that the Acts, by keeping alive a sense of friction, left the people in just the state of nind to seize with eagerness on the more palpable wrongs which were specifically brought forward as the justification for resistance. It was really the groundwork of the movement, though if it had been the only cause, might not have precipitated open resistance to the Government.

${ }^{30}$ G. L. Beer, The Old Colonial System, Vol. II, p. I I 5 .

${ }^{31}$ Secretary Thomas Ludwell in a long report to the British Government spoke of the Virginia Government as Berkeley's own, "Which I so term," he explains, "because he is the sole author of the most substantial parts of it, either for Lawes or other inferior institutions." British Public Record Office, COI-20.

${ }^{32}$ British Museum, Egerton Manuscript, 2395, f. 356b.

${ }^{33}$ British Public Record Office, COI-I9, Berkeley to Lord Arlington, Aug. I, I665.

${ }^{34}$ P. A. Bruce, Economic History of Virginia, Vol. I, pp. 399400 .

${ }^{35}$ British Public Record Office, COI-26-77, Berkeley to the Board of Trade.

${ }^{36}$ British Public Record Office, COI-30-78, Mcmorial of John Knight, Oct. 29, 1673.

${ }^{37}$ British Public Record Office, COI-30-7I, Council of Virginia to the King, I673.

${ }^{38}$ Peter Force, Tracts and Other Papers, Vol. II, New Description of Virginia, pp. I-I6.

${ }^{39}$ British Museum. Egerton Manuscript, 2395, f. 356b, A Discourse and View of Virginia.

${ }^{40}$ British Public Record Office, COI-26-77, Berkeley to the Board of Trade. 
41 British Public Record Office, COI-34-95, Petition of Francis Moryson, Thomas Ludwell and Robert Smith.

${ }^{42}$ Virginia Land Patents, Register of Land Office, Virginia State Capitol.

${ }^{43}$ British Public Record Office, CO5-I359, Pp. 20, 21, 22, Colonial Entry Book.

\section{NOTES TO CHAPTER VI}

${ }^{1}$ Peter Force, Tracts and Other Papers, Vol. II, New Description of Virginia, p. 3.

${ }^{2}$ British Public Record Office, COI-30, pp. 17, 5 I.

${ }^{3}$ Surry County Wills, Deeds, Etc. I67I-I624, Virginia State Library.

${ }^{4}$ Surry County Wills, Deeds, Etc. I684-1686, pp. 34-35, Virginia State Library.

${ }^{5}$ Surry County Wills, Deeds, Etc. I684-I686, pp. 86-87, Virginia State Library.

${ }^{6}$ P. A. Bruce, Economic History of Virginia, Vol. II, p. I99.

${ }^{7}$ Peter Force, Tracts and Other Papers, Vol. II, New Description of Virginia, p. 3.

${ }^{8}$ P. A. Bruce, Economic History of Virginia, Vol. II, p. 200.

${ }^{9}$ Peter Force, Tracts and Other Papers, Vol. II, New Description of Virginia, p. 3.

${ }^{10}$ Peter Force, Tracts and Other Papers, Vol. II, New Description of Virginia, p. I8.

${ }_{11}$ Peter Force, Tracts and Other Papers, Vol. II, New Description of Virginia, p. I 5.

${ }^{12}$ P. A. Bruce, Economic History of Virginia, Vol. II, p. 20 I. ${ }^{13}$ Peter Force, Tracts and Other Papers, Vol. III, Leah and Rachel, p. I3.

${ }^{14}$ British Public Record Office, CO5-13I6, Statement of $\mathrm{Mr}$. Perry and Captain Hyde, Correspondence of the Board of Trade. ${ }_{15}$ Peter Force, Tracts and Other Papers, Vol. III, Virginia Richly Valued, p. ro.

${ }^{16}$ Peter Force, Tracts and Other Papers, Vol. II, New Albion, p. 32 .

${ }_{17}$ Peter Force, Tracts and Other Papers, Vol. III, Leah and Rachel, p. I8.

${ }^{18}$ Peter Force, Tracts and Other Papers, Vol. II, New Description of Virginia, p. 7.

${ }^{19}$ Abstracts of Proceedings of the Virginia Company of London, Vol. II, p. I7I. 
${ }^{20}$ P. A. Bruce, Economic History of Virginia, Vol. II, p. I53.

${ }^{21}$ P. A. Bruce, Economic History of Virginia, Vol. II, pp. I60-I6I.

${ }^{22}$ Virginia Magazine of History and Biography, Vol. V, p. 285.

${ }^{23}$ Surry County IVills, Deeds, Etc. I684-I686, p. 7, Virginia State Library.

${ }^{24}$ Surry County IVills, Deeds, Etc. I684-1686, pp. 34-35, Virginia State Library.

${ }^{25}$ Surry County Wills, Deeds, Etc. I684-1686, pp. 86-87, Virginia State Library.

${ }^{26}$ Surry County Wills, Deeds, Etc. I67I-I684, Virginia State Library.

${ }^{27}$ John Splitimber paid for himself alone in the tithable lists of 1675 .

${ }^{28}$ York County Records, 1694-I702, Virginia State Library.

${ }^{29}$ Peter Force, Tracts and Other Papers, Vol. II, New Description of Virginia, p. 15.

${ }^{30}$ Peter Force, Tracts and Other Papers, Vol. II, New Description of Virginia, p. I4.

${ }^{31}$ British Public Record Office, CO5-137I, p. 241.

32 "I would have all men consider how meanly we are provided of men of learning, ability and courage, nay indeed of honesty, to stand up in the people's behalf and oppose the oppressing party," said Nathaniel Bacon in 16 6 . British Public Record Office, $\mathrm{CO}_{5}-\mathrm{I} 37 \mathrm{I}$, p. 246.

${ }^{33}$ The most notable case of betrayal is that of Isaac Allerton, who sold himself to the Governor for the promise of a seat in the Council of State. British Public Record Office, CO5-I356, pp. I25-I26, Colonial Entry Book.

${ }^{34}$ British Public Record Office, COI-4.

${ }^{35}$ P. A. Bruce, Economic History of Virginia. Vol. I, pp. 287288.

${ }^{36}$ Virginia Magazine of History and Biography, Vol. X, p. 27 I.

${ }^{37}$ British Public Record Office, COI-8, p. 48.

${ }^{38}$ British Public Record Office, COI-8.

${ }^{39}$ Hening, Statutes at Large, Vol. I. pp. 360-361.

${ }^{40}$ Hening, Statutes at Large, Vol. I. p. $36 \mathrm{r}$.

${ }^{41}$ Hening, Statutes at Large. Vol. I, p. 355.

${ }^{42}$ Hening. Statutes at Large. Vol. I. p. $3^{63}$.

${ }^{43}$ Sixth Report of Royal Commission on Historical Manuscripts, Part I, Instructions to Sir George Ayscue, Sept. 26. I65I. ${ }^{44}$ The commissioners were Capt. Robert Dennis, Richard Ben- 
nett, Thomas Stegge and Captain William Claiborne, all of whom with the exception of Dennis were Virginians.

${ }^{45}$ Hening, Statutes at Large, Vol. I, pp. 371, 373.

${ }^{46}$ Southern Literary Messanger, Jan. 1845; Charles Campbell, History of Virginia, p. 74.

${ }^{47}$ Southern Literary Messanger, Jan. 1845.

${ }^{48}$ British Public Record Office, CO5-137r, p. 387, Colonial Entry Book.

\section{NOTES TO CHAPTER VII}

${ }^{1}$ British Public Record Office, CO5-I356, p. I04, Colonial Entry Book.

${ }^{2}$ G. L. Beer, The Old Colonial System, Vol. I, p. 40.

${ }^{3}$ British Public Record Office, CO5-I305, Document 23, Correspondence of the Board of Trade.

${ }^{4}$ British Public Record Office, CO5-1345, Document 16, Correspondence of the Secretary of State.

${ }^{5}$ G. L. Beer, The Old Colonial System, Vol. I, p. 42.

${ }^{6}$ Calendar of State Papers, Colonial Series, 1702.

${ }^{7}$ British Public Record Office, CO5-I355, pp. 38r-385, Colonial Entry Book.

${ }^{8}$ G. L. Beer, The Old Colonial System, Vol. I, p. 168.

${ }^{9}$ British Public Record Office, CO5-I315, Document 16, Correspondence of the Board of Trade.

${ }^{10}$ British Public Record Office, CO5-I315, Document 9r.

${ }^{11}$ British Public Record Office, CO5-1345, Document 16 , John Linton to the Board of Trade, Correspondence of the Secretary of State.

${ }_{12}$ British Public Record Office, CO5-I315, Report of John Linton on the Tobacco Trade, Correspondence of the Board of Trade.

${ }^{13}$ British Public Record Office, CO5-1345, Document 16, Correspondence of the Secretary of State.

${ }^{14}$ British Public Record Office, CO5-1315, Document 26, Correspondence of the Board of Trade.

${ }_{15}$ British Public Record Office, CO5-1315, Document 26, Correspondence of the Board of Trade.

${ }^{16}$ British Public Record Office, CO5-1316, Correspondence of the Board of Trade.

${ }^{17}$ British Public Record Office, CO5-1340, Document 9r, Col. Quary's Memorial. 
${ }^{18}$ R. L. Beer, The Old Colonial System, Vol. I, p. 42.

${ }^{19}$ British Public Record Office, CO5-I3I6, Correspondence of the Board of Trade; $\mathrm{CO}_{5}-1360$, p. 233, Governor Nicholson to the Lords of Trade.

${ }^{20}$ British Public Record Office, CO5-I3I5, Document 9I, Col. Quary's Memorial.

${ }_{21}$ British Public Record Office, CO5-I3I5, Correspondence of the Board of Trade, Letter of Col. Quary Sept. I, I706.

${ }^{22}$ Princeton Transcripts, Virginia Land Patents, Princeton University Library.

${ }^{23}$ Britain Public Record Office, CO5-I359, pp. I07-I08, Colonial Entry Book. In 1699 Gov. Nicholson stated that Orinoco was bringing 20 shillings the hundredweight and Sweetscented 25 shillings and up, which he considered an unusually good return. British Public Record Office, CO5-I359, p. 322.

${ }^{24}$ P. A. Bruce, Economic History of Virginia, Vol. II, p. 66.

${ }^{25} \mathrm{~J}$. C. Hotten, Original Lists of Emigrants to America, pp. 202-265.

${ }^{26}$ P. A. Bruce, Economic History of Virginia, Vol. II, p. 89.

${ }^{27}$ Peter Force, Tracts and Other Papers, Vol. II, New Description of Virginia, p. 3.

${ }^{28}$ British Public Record Office, COI-26-77, Berkeley to the Board of Trade.

${ }^{29}$ British Public Record Office, $\mathrm{CO}_{5-1} \mathrm{3} 55$, p. 345, Lord Culpeper's account of his compliance with the King's instructions, Dec. I68I.

${ }^{30} \mathrm{P}$. A. Bruce, Economic History of Virginia, Vol. II, p. 75.

${ }^{31} \mathrm{P}$. A. Bruce, Economic History of Virginia, Vol. II, p. 75.

${ }^{32}$ British Public Record Office, COI-26-77, Berkeley to the Board of Trade.

${ }^{33}$ G. L. Beer, The Old Colonial System, Vol. I, p. 323.

${ }^{34}$ G. L. Beer, The Old Colonial System, Vol. I, pp. 324-325.

${ }^{35}$ York County Records, I664-I672, Virginia State Library.

${ }^{36}$ York County Records, I694-1702, Virginia State Library.

${ }^{32}$ Henrico Records, I677-1692, Virginia State Library.

${ }^{38}$ York County Records, I694-1697, Virginia State Library.

${ }^{38}$ British Public Record Office, CO5-I3I7, Correspondence of the Board of Trade.

${ }^{40}$ British Public Record Office, CO5-1317, Correspondence of the Board of Trade.

41 British Public Record Office, CO5-I406, Minutes of the 
Council March 21, I7Io, CO5-I363, pp. I89-19I, Colonial Entry Book.

${ }^{42}$ British Public Record Office, CO5-I322, Governor Gooch to the Lords of Trade, Sept. I4, I730; Feb. I2, I73I.

${ }^{43}$ British Public Record Office, $\mathrm{CO}_{5}-1363$, pp. 317-324, Coionial Entry Book.

${ }_{44}$ British Public Record Office, CO5-1362, pp. 369-373, Colonial Entry Book.

${ }_{45}$ P. A. Bruce, Economic History of Virginia, Vol. II, p. 83.

${ }^{46}$ Princeton Transcripts, Virginia Land Patents, Princeton University Library.

${ }^{47}$ P. A. Bruce, Economic History of Virginia, Vol. II, p. 108.

${ }^{48}$ British Public Record Office, CO5-13I6, Correspondence of the Board of Trade.

${ }^{49}$ British Public Record Office, CO5-I3I4, Document 66, Governor Nott to the Board of Trade.

${ }^{50}$ British Public Record Office, $\mathrm{CO}_{5-1} 362$, pp. 365-367, Colonial Entry Book.

${ }^{51}$ British Public Record Office, CO5-1362, pp. 365-367, Colonial Entry Book.

${ }^{52}$ During these years the planters were too impoverished to purchase slaves. The decline in the tobacco trade produced a feeling among the people that the colony had been overstocked with blacks.

${ }^{53}$ British Public Record Office, CO5-I322, Correspondence of the Board of Trade, Report of Governor Gooch.

${ }_{54}$ British Public Record Office, CO5-1322, Francis Fane to the Lords of Trade, Dec. Io, I728.

${ }^{55}$ British Public Record Office, CO5-1356, p. I39, Colonial Entry Book.

\section{NOTES TO CHAPTER VIII}

${ }^{1}$ Princeton Transcripts, Virginia Land Patents, Princeton University Library.

${ }^{2}$ Princeton Transcripts, Virginia Land Patents, Princeton University Library.

${ }^{3}$ British Public Record Office, CO5-1362, pp. 365-367, Colonial Entry Book.

${ }^{4}$ Virginia Land Patents, Register of Land Office, Virginia State Capitol.

${ }^{5}$ G. L. Beer, The Old Colonial System, Vol. I, p. 28. 
${ }^{6}$ G. L. Beer, The Old Colonial System, Vol. I, pp. 320-32I.

' Jared Sparks, The Works of Benjamin Franklin, Vol. X, iii.

${ }^{8}$ Maurice Vanlaer, La Fin d'un Peuple, pp. 38-39.

${ }^{9}$ Maurice Vanlaer, La Fin d'un Peuple, pp. I12-II7.

${ }^{10}$ British Public Record Office, COI-39-38.

${ }^{11}$ Calendar of State Papers, Colonial Series, I696-1697, p. 420.

${ }^{12}$ Calendar of State Papers, Colonial Series, I696-I697, p. 500.

${ }^{13}$ Calendar of State Papers, Colonial Series, I696-1697, p. 546.

${ }^{14}$ British Public Record Office, CO5-I359, pp. 20, 2 I, 22.

${ }^{15}$ British Public Record Office, CO5-1359, pp. 20, 21, 22. Book.

${ }^{16}$ British Public Record Office, CO5-I359, p. 23, Colonial Entry

${ }^{17}$ British Public Record Office, CO5-1359, p. II3, Andros to the Lords of Trade, July I, 1697.

${ }^{18}$ British Public Record Office, CO5-1359, pp. 266-303, Colonial Entry Book.

${ }^{19}$ British Public Record Office, CO5-I312, p. 409A, Correspondence of the Board of Trade.

${ }^{20}$ British Public Record Office, CO5-I360, p. 441, Colonial Entry Book.

${ }^{21}$ Rent Roll of I704, p. 46.

${ }^{22}$ British Public Record Office, $\mathrm{CO}_{5}$-I $32 \mathrm{I}$, Correspondence of the Board of Trade, Gooch to the Lords of Trade, Nov. 6, 1728.

${ }^{23}$ British Public Record Office, CO5-1362, pp. 374-382, Colonial Entry Book.

${ }^{24}$ British Public Record Office, CO5-1364, p. 27, Colonial Entry Book.

${ }^{25} \mathrm{~J}$. S. Bassett, Writings of William Byrd, p. $3 \mathrm{I}$.

${ }^{26}$ British Public Record Office, CO5-I322, Gooch to the Lords of Trade, Feb. 27, I73I.

${ }^{27}$ British Public Record Office, CO5-1321, Gooch to the Lords of Trade, Aug. 9, 1728.

${ }^{28}$ British Public Record Office, CO5-1315, Document I6, Correspondence of the Board of Trade.

${ }^{29}$ British Public Record Office, CO5-I3I5, Document 9I, Correspondence of the Board of Trade.

${ }^{30}$ British Public Record Office, CO5-I3I6, Correspondence of the Board of Trade.

${ }^{31}$ British Public Record Office, CO5-1315, Document 16.

${ }^{32}$ British Public Record Office, CO5-I315, Document 91, Correspondence of the Board of Trade. 
${ }^{33}$ British Public Record Office, CO5-I3I5, Correspondence of the Board of Trade.

${ }^{34}$ British Public Record Office, CO5-1316, Account of the tobacco trade by Perry and Hyde, June 2, I7 14.

${ }^{35}$ British Public Record Office, CO5-I3I6, Petition of the Council, Correspondence of the Board of Trade.

${ }^{36}$ British Public Record Office, CO5-I3I8, Address of King and Queen county inhabitants to Spotswood; address of Westmoreland inhabitants; letter of Spotswood to Lords of Trade, Dec. 22, 1718 .

${ }^{37}$ William and Mary Quarterly, Vol. XXI, pp. I06-I22.

${ }^{38}$ Virginia Magazine of History and Biography, Vol. XII, pp. 4I 4-4I6.

${ }^{39}$ Virginia Magazine of History and Biography, Vol. IV, pp. 297-299.

${ }^{40}$ William and Mary Quarterly, Vol. XXVI, pp. 97-I06, 19620I, 250-258.

${ }^{41}$ Chastellux, Travels in North America, p. 291.

${ }^{42}$ Philip Fithian, Journal and Letters, p. 243.

${ }^{43}$ Smyth, A Tour of the United States, Vol. I, p. 58.

14 William and Mary Quarterly, Vol. XXI, pp. I06-122.

${ }^{45}$ William and Mary Quarterly, Vol. XXVI, pp. 97-Io6, 19620I, 250-258.

${ }^{46}$ Virginia Magazine of History and Biography, Vol. IV, pp. 297-299.

${ }^{47}$ Virginia Magazine of History and Biography, Vol. XII, p. 415.

${ }_{48}^{48}$ Lower Norfolk County Antiquary, Vol. IV, p. I44.

${ }^{49}$ W. A. Crozier, Virginia County Records, Vol. I, pp. 88-I Io.

${ }^{50}$ Thomas Jefferson, Notes on Virginia, Edition of 1801, p. 321.

${ }^{51}$ Chastellux, Travels in North America, p. 292 note.

${ }^{52}$ Smyth, A Tour of the United States, Vol. I, p. 66.

${ }^{53}$ Hugh Jones, History of Virginia, p. $3^{6 .}$

${ }^{54}$ Rowland, Life of George Mason, Vol. I, pp. I01, I02; Philip Fithian, Journal and Letters, pp. 67, I04, I30, I 30, I 38, 217, 259; P. A. Bruce, Economic History of Virginia, Vol. II, pp. 4I I, 4I8. ${ }_{55}$ British Public Record Office, CO5-I3I4, Document 63IV. ${ }^{56}$ Virginia Magazine of History and Biography, Vol. XII, p. $4 I 5$.

${ }^{57}$ Virginia Magazine of History and Biography, Vol. IV, pp. 292-299. 
I 80 NOTES

${ }^{58}$ William and Mary Quarterly, Vol. XXVI, pp. 97-I06, I9620I, 250-258.

${ }^{59}$ Smyth, A Tour of the United States, p. 67.

${ }^{60}$ Anbury, Travels Through America, Vol. II, p. 330.

${ }^{61}$ Virginia Magazine of History and Biography, Vol. XII, p. $4 I 5$. 
APPENDIX 



\section{RENT ROLL OF VIRGINIA}

\section{704-I 705}

A True and Perfect Rent Roll of all the Lands held of her Maj" ${ }^{\text {te }}$ in Henrico County, Aprill 1705

\section{A}

Andrews Thomas ....... 396

Ascoutch Mary ......... 633

Archer Jno ............ 335

Adkins Jno $\ldots \ldots \ldots \ldots \ldots . \quad 125$

Archer Geo .............. $173^{8}$

Aldy John ............. 162

Akins James $\operatorname{Sen}^{r} \ldots \ldots \ldots 200$

Asbrook Peter Sen ${ }^{r} \ldots \ldots .200$

Akins James Jun ${ }^{\mathbf{r}} \ldots \ldots \ldots .218$

Allin Widd $^{\circ} \ldots \ldots \ldots \ldots \ldots . \quad 99$

4106

$\mathrm{B}$

Byrd Esq ${ }^{r} \ldots \ldots \ldots \ldots \ldots$ I9500

Bolling Rob ${ }^{2} \ldots \ldots \ldots \ldots \ldots,{ }_{500}$

Bolling John $\ldots \ldots \ldots \ldots \ldots$. $83 \mathrm{I}$

Bevill John ............ 495

Branch $X^{\text {to }} \ldots \ldots \ldots \ldots \ldots \ldots . .6 \%$

Blackman $\mathrm{Wm} \ldots \ldots \ldots \ldots \ldots$. 175

Bridgwater Sam ......... 280

Bowman John Jun ${ }^{\mathrm{r}} \ldots \ldots \ldots, \quad 300$

Bowman Edw ${ }^{\mathrm{d}} \ldots \ldots \ldots \ldots ., 300$

Branch Benj .............. 550

Brown Martha .......... 893

Bullington Benj .......... 100

Bowman Lew ............ $6_{5}$

Bullington $\ldots \ldots \ldots \ldots \ldots \ldots$ I 44

Bevell Essex ........... 200

Baugh John ............ 448

Baugh James $\ldots \ldots \ldots \ldots \ldots,{ }_{45}$

Burton Isaac ........... 100

Bottom John ............. 100

Bayley Abr $\ldots \ldots \ldots \ldots \ldots \ldots \ldots$. 542

Brooks Jane belonging to Wm Walker New Kent.. Braseal Henry ........... Brazeal Henry Jun ${ }^{\mathrm{r}} \ldots \ldots$....

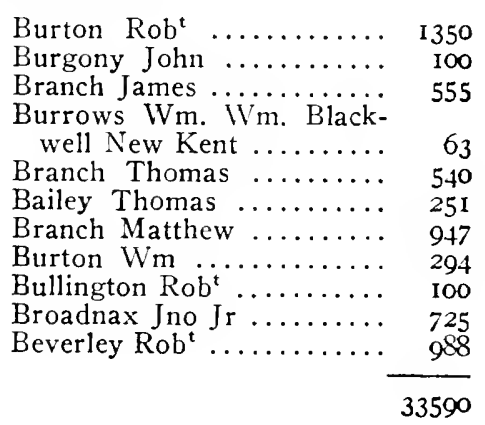

C

Cheatham Tho ......... 300

Cox Batt ...............

Cox John ............. 150

Cox George ............ 200

Chamberlaine Maj. Tho ... I000

Childers Abr. Sen ${ }^{r}$....... 368

Cannon John ............. 108

Cox Wm .............. 300

Childers $\mathrm{Ab}^{\mathrm{r}}$ Jun ${ }^{\mathrm{r}} \ldots \ldots \ldots . .10 .100$

Clark Wm ................ 333

Clark John ............ 300

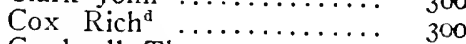

Cardwell Tho ........... 350

Crozdall Roger ........... 200

Cock Wm ............. 1535

Cock Rich $^{\mathrm{d}} \operatorname{Sen}^{\mathrm{r}} \ldots \ldots \ldots \ldots \ldots$...... 2180

Childers Philip $\operatorname{Sen}^{\mathrm{r}} \ldots \ldots . .6 \%$

Childers Philip .......... 300

Childers Tho $\ldots \ldots \ldots \ldots \ldots, 300$

Carter Theod $\ldots \ldots \ldots \ldots \ldots \ldots$. 75

$550 \quad$ Cock Capt Thomas ......... $2976 \mathrm{6} / 2$

$200 \quad$ Couzins Charles .......... 362

$300 \quad$ Clerk Alonson ............. 604 
Cock James ............ 1506

Curd $E^{2} w^{\mathrm{d}} \ldots \ldots \ldots \ldots \ldots 600$

Cock Rich ${ }^{\mathrm{d}} \ldots \ldots \ldots \ldots \ldots \ldots \ldots, 476$

Cock Jno ............ 98

$15171 / 2$

D

Dixon Nicholas ......... I50

Dodson Wm ............. I00

Douglas Charles ......... 63

313

$\mathrm{E}$

$\mathrm{Edw}^{\mathrm{d}}$ Tho $\ldots \ldots \ldots \ldots \ldots, 676$

Entroughty Derby ....... 200

Ealam Rob ${ }^{t} . . . \ldots \ldots \ldots .400$

Ellis John ............ 217

East Tho Sen ........... 475

East Tho $\ldots \ldots \ldots \ldots \ldots \ldots$. 554

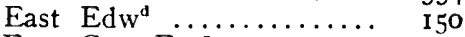

Epes Capt Fra .......... 2r45

Evans Charles .......... 225

Ealam Martin .......... r 30

Epes Isham, Epes Fra. Jun ${ }^{\mathrm{t}}$ each $444 \frac{1}{2}$ acres ........ 889

$606 \mathrm{I}$

\section{$F$}

Field Peter Major ........

Farrar Capt Wm ...........

Farrar Tho $\ldots \ldots \ldots \ldots \ldots$.

Fowler Godfrey .............

Ferguson Robert ..........

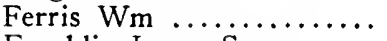

Franklin James Sen .......

Franklin James Jun ........

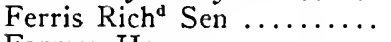

Farmer Henry ............

Forrest James ...........

Forrest John ..............

Fetherstone Henry .........

Farloe John Sen ...........

Farloe John Jun ..........

Faile John $\ldots \ldots \ldots \ldots \ldots$

2185

700

I444

600

250

230

50

250

786

$55^{\circ}$

100

138

150

700

100

551

240

9024

G

Gilley Grewin Arrian .... 2528

Gee Henry ............. 435

Good John Sen .......... 600
Garthwaite Sam' ....... 50

Garthwaite Ephriam ....... I6

Granger John ......... 472

Gill John ............. 235

Good Sam ${ }^{1} \ldots \ldots \ldots \ldots \ldots \ldots . .65$

Gower James Grigs Land.. 500

$557 \mathrm{I}$

$\mathrm{H}$

Hill James ..............

795

Holmes Rich ..............

100

Harris Thomas ......... 357

Harris $\operatorname{Tim}^{\circ} \ldots . . \ldots \ldots \ldots 250$

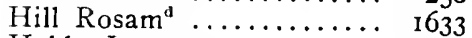

Hobby Lawrence ......... 500

Hatcher John ........... 215

Haskins Edward .......... 225

Hatcher Edward Sen ...... I50

Hunt Geo .............. 200

Hughs Edward ...........

Hancock Samuel ......... 100

Holmes Thomas ......... 50

Hambleton James ........ 100

Hutchins Nich ......... 240

Hatcher Benj Sen ......... 250

Hatcher Wm Jun ........ 50

Hobson $W m$............ ${ }_{150}$

Hatcher Wm Sen .......... 298

Hatcher Henry ........... 650

Hancock Robert ......... 860

Harris Mary ............ 94

Hall Edward ............. r 9

Herbert Mrs ............ 1360

Hudson Robert ......... 281

9242

$\mathrm{J}$

Jones Hugh .......... 934

Jefferson Thomas ........ 492

Jones Philip .............. 1153

Jorden Henry ..........

Janison John ........... 225

Jackson Ralph .......... 250

$\mathrm{K}$

3154

Kennon Elizabeth ....... 1900

Knibb Samuel ........... 209

Knibb Solomon ......... 833

Kendall Richard ........... 400

3342 


\section{L}

Liptroll Edward

Lewis $\mathrm{Wm}$............. 350

Lester Darens .......... IO0

Ladd $\mathrm{Wm} \ldots \ldots \ldots \ldots \ldots \ldots .70$

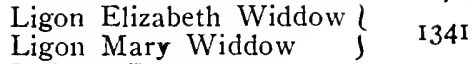

Laforce Reu ........... 100

Lochett James .......... 50

Lownd Henry ............ 516

Lockitt Benj ........... I04

Ligon Richard .......... I028

Ligon Hugh $\ldots \ldots \ldots \ldots \ldots$ I50

3959

\section{M}

Mann Robert ........... I00

Matthews Edward ........ 330

Moseby Edward ......... I50

Moseby Arthur ......... 450

I030

$\mathrm{N}$

Nunnally Richard

70

$\mathrm{O}$

Osbourn Thomas ........ 288

Owen Thomas .......... 68

356

Perkinson $\mathrm{P}$

Perrin Ann ............. 500

Pleasants John .......... 9669

Parker Wm ............ I00

Parker Nich Sen ......... 500

Pledge Jno ............ I00

Powell Robert .......... I50

Peice John ............ I30

Pleasants Jos .......... I709

Porter Wm ............ 305

Peirce Wm ............ I75

Peirce Francis .......... 3I

Paine Thomas .......... 300

Portlock Elizabeth ....... I000

Pero Henry ........... 350

Pattram Ira ........... 778

Pride $W m$ Sen .......... 1280

Pollard Thomas Sen ..... I30
Perkinson Seth .......... 50

Pinkitt Wm ........... $\mathbf{I}^{92}$

Pinkitt Thomas ......... 300

Pattison Joseph ......... 500

Porter John .......... I00

Pollard Thomas Jun ..... 235

Pollard Henry .......... 235

Pinkitt John .......... 215

19937

$\mathrm{R}$

Robertson Geo ........... I445

Ragsdaile Godfrey ....... 450

Rawlett Peter ........... I64

Russell Charles ......... 200

Rowlett Wm ........... 200

Rowen Francis ......... $\mathbf{1 4 8}$

Robertson John ......... 4I5

Rouch Rachell ......... 300

Robertson Thomas ....... 200

Russell John ........... 93

Royall Joseph ........... 783

Redford John .......... 775

Randolph $\mathrm{Col} \mathrm{Wm}$ including II 85 acres swamp $\ldots 9465$

I 4648

$\mathrm{S}$

Steward Jno Jun ........ 902

Scott Walter ............ 550

Soane Capt Wm .......... 384I

Stanley Edward ......... 300

Snuggs Charles ......... 400

Sewell $\mathrm{Wm}$.............. 59

Smith Humphrey ......... 40

Sharp Robert ........... 500

Stovoll Barth ${ }^{\circ} \ldots \ldots \ldots \ldots$. IOO

Skerin Widdow ........... 75

Steward Daniell ......... 270

Smith Obadiah ........... 200

Stowers Widdow ......... 200

Sarrazin Stephen ........ I20

7557

\section{$T$}

Tancocks Orphans ....... I230

Trent Henry ........... 224

Turpin Thomas ......... 49I

Turpin Philip ........... 444

Turpin Thomas .......... 100 


\begin{tabular}{|c|c|}
\hline Turuer Heury & \\
\hline Taylor Thomas . & 475 \\
\hline Tanner Edward ........... & 217 \\
\hline Traylor Edward & 100 \\
\hline Totty Thomas .... & 260 \\
\hline Traylor $\mathrm{Wm}$.... & 730 \\
\hline & +471 \\
\hline V & \\
\hline Veden Henry ........... & 100 \\
\hline W & \\
\hline Woodson John ... & 4060 \\
\hline Williams Robert $\ldots \ldots \ldots \ldots$ & 300 \\
\hline Woodson Robert Jun ...... & II 57 \\
\hline 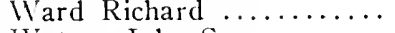 & 300 \\
\hline Watson John Sen ......... & 1603 \\
\hline Walthall Wm ............. & 500 \\
\hline Walthall Henry ......... & 832 \\
\hline Whitby Wm $\ldots \ldots \ldots \ldots$ & 215 \\
\hline Watkins Henry Sen ..... & 100 \\
\hline Webb John $\ldots \ldots \ldots \ldots \ldots$ & 100 \\
\hline Watkins Thomas ......... & 200 \\
\hline Woodson Rich ............ & 180 \\
\hline Woodson Widdow ......... & 650 \\
\hline Williamson Thomas ...... & 1077 \\
\hline Webb Giles...$\ldots \ldots \ldots$ & 7260 \\
\hline Wood Thomas $\ldots \ldots \ldots \ldots$ & 50 \\
\hline Watkins Wm...$\ldots \ldots \ldots$ & I 20 \\
\hline Watkins Jos $\ldots \ldots \ldots \ldots \ldots$ & 120 \\
\hline Watkins Edward $\ldots \ldots \ldots \ldots$ & 120 \\
\hline Ward Seth $\ldots \ldots \ldots \ldots \ldots$ & 700 \\
\hline Wood Moses . . . . . . . . . & 100 \\
\hline Wilkinson Jos $\ldots \ldots \ldots \ldots$ & $751 / 2$ \\
\hline Wilkinson John $\ldots \ldots \ldots \ldots$ & I30 \\
\hline Worsham John ........... & 1104 \\
\hline Womack Abr ............ & 560 \\
\hline Willson Jno Sen $\ldots \ldots \ldots \ldots$ & I 686 \\
\hline Willson Jno Jun $\ldots \ldots \ldots$ & 100 \\
\hline Walthall Richard ......... & 500 \\
\hline Wortham Geo ........... & 400 \\
\hline Wortham Charles ........ & 90 \\
\hline Womack Wm $\ldots \ldots \ldots \ldots \ldots$ & 100 \\
\hline & $24189^{1 / 2}$ \\
\hline W $\ldots \ldots \ldots \ldots \ldots 244891 / 2$ & \\
\hline $\begin{array}{lr}\ldots \ldots \ldots \ldots \ldots & 100 \\
\ldots \ldots \ldots \ldots \ldots & 4471\end{array}$ & \\
\hline$\cdots \cdots 44 / 1$ & \\
\hline
\end{tabular}

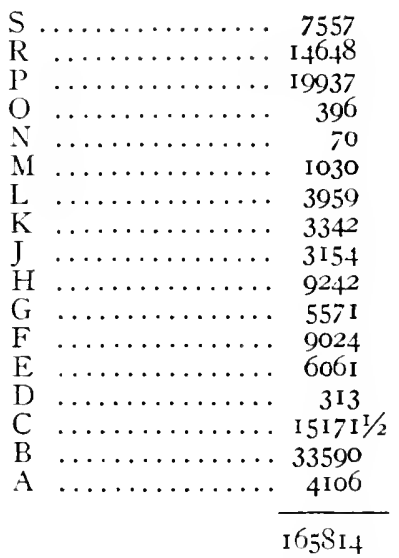

Out of which must be deducted these several quantities of land following Viz:

Tancocks Orphans Land .. I230 Allens Orphans Land .....

An account of Land that hath been concealed

John Steward Jun ....... 2

Thomas Jefferson ........ I5

Thomas Turpin ......... Io

Henry Gee ............. Io

Stephen Sarrzen ......... I0

Mr. Lownd ........... I

James Atkin Sen ........ 32

Matthew Branch ......... 10

James Franklin ........ 360

James Hill ............. 50

Rosemond Hill ......... 33

John Bullington ........ 44

Benjamin Lockett ........ 4

John Russell ........... 23

Charles Douglas ........ I3

Col Randolph

Carless Land ........ 1049

1669

The Quit Rent being I62719 acres. 
A Rent Roll of all the Lands held in the County of Prince George for the Year 1704

A

Thomas Anderson

Wm Aldridge

Mr. Charles Anderson .... 505

Richard Adkinson ....... 200

Thomas Adams ........ 250

Matthem Anderson ...... 349

Henry Ally ............ 390

Wm Anderson .......... 235

Jno Anderson ........... 228

Henry Anderson ......... 250

Robert Abernathy ....... IO

Jno Avery ............. 100

3217

\section{B}

Richard Bland

B..........

Robert Birchett .............

Arthur Biggins ..........

James Benford ............

Jno Barloe ..............

Charles Bartholomew ....

Philip Burlowe ..........

Nicholas Brewer .........

Jno Bishop Sen ..........

Jno Bishop Jun ...........

Isaac Baites ............

Thomas Busby Capt .......

Thomas Busby ...........

Wm Batt ...............

Coll Byrd Esq .............

Edward Birchett .............

Coll Bolling ............... 3402

Edmund Browder ....... 100

Matus Brittler ............ 5 I0

Jno Butler ............. I 385

Andrew Beck ......... 300

Henry Batt ........... 790

Wm Butler .............. 283

Thomas Blitchodin ........ 284

12986

C

Thomas Curiton ......... 150

Henry Chammins ........ 300

Capt Clements ......... 1920

Wm. Claunton ......... I00

Robert Catte ........... I00
Bartho Crowder ......... 75

Thomas Clay ........... 70

Jno Coleman .......... 200

George Crook .......... 489

Francis Coleman ......... 150

Jno Clay .............. 350

Wm Coleman Jun .......

George Croohet .......... 30

James Cocke ........... 750

Robert Carlill ........... IOO

Jno Clerk ............ $8_{3}$

Richarl Claunton ........ I00

Stephen Cock for Jones Orphans ........ 2405

7622

\section{D}

Thomas Daniell ......... I50

Roger Drayton ........... 270

Joseph Daniell .......... 50

Jno Doby .............. 500

George Dowing .......... IOO

$1 \mathrm{~lm}$ Davis ............. 100

Ino Duglas ............ 300

Richard Darding ........ 500

Christopher Davis ....... 50

Thomas Dunkin ........ 136

2156

\section{$\mathrm{E}$}

Robert Ellis .......... 50

Ino Epes Sen ........... 530

Wm Epes Sen ............ 750

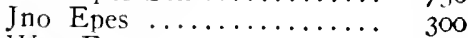

IIm Epes .............. $633^{1 / 2}$

Edward Epes ........... 500

Littlebury Epes ............ $\quad 8_{33} 1 / 2$

Benj Evans ............ 700

Thomas Edwards ......... 250

Dan Epes .............. 200

Jno Evans ............. 800

Jno. Ellis Jun .......... 400

John Ellis Sen .......... 400

Mary Evans ............. 400

Peter Evans ............ 270

Capt Francis Epes ......... 226

7243 
F

Jno Freeman $\ldots \ldots \ldots \ldots \ldots \quad 300$

$\mathrm{W} \mathrm{W}$ Frost ............ 50

Jno Fountaine ......... 350

Robert Fellows .......... 4 48

Elizabeth Flood .......... I00

Benj Foster ............. 923

Jno Field $\ldots \ldots \ldots \ldots \ldots \ldots$ I00

2241

G

Jno Green $\ldots \ldots \ldots \ldots \ldots \ldots$

Richard Gord ...............

David Goodgamd ..........

James Greithian ...........

Major Goodrich ..........

Thomas Goodwin ...........

Hubert Gibson ............

Richard Griffith ...........

James Griffin .............

Charles Gee .............

Charles Gillam ...........

Hugh Goelightly ..........

Lewis Green ............

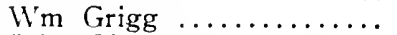

John Gillam ............. 1000

John Goelightly ........ 100

5435

\section{$\mathrm{H}$}

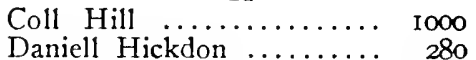

1000

Robert Harthorn ........ 243

Jno Hamlin ............ I $4844^{1} / 2$

Coll Harrison Esq ........ I50

Ralph Hill ............ I75

Wm Harrison ........... I930

Wm Heath ............. 320

Edward Holloway ........ 100

Robert Hobbs ........... 100

Jno Hobbs Sen .......... 250

Edward Holloway Sen .... 620

Jno Hobbs ............. 100

James Harrison ........... 200

Gilbert Haye ............. 200

Richard Hudson .......... 75

Gabriell Harrison ......... 150

Robert Hix ............. I0OO

Joseph Holycross ......... 84

Charles Howell .......... I25

Sam Harwell ........... 125
Isaac Hall .......... 450

Jno Howell ........... 183

Thomas Howell ......... 25

Mrs. Herbert .......... 3925

Jno Hixs $\ldots \ldots \ldots \ldots \ldots \ldots .216$

Richard Hamlin ......... 240

Thomas Harnison ........ 1077

Elizabeth Hamlin ........ 250

Wm Hulme ............ I00

Jeffrey Hawkes .......... I25

Adam Heath ........... 300

Jno Hill .............. I6

Jno Hardiman .......... 872

Justance Hall ............ 614

17366

\section{$\mathrm{J}$}

$\mathrm{Wm}$ Jones Jun .......... 230

Wm Jones Sen .......... 600

Henry Jones ............ 200

Robert Jones ........... 24I

Edmund Irby ........... 800

Nich. Jarrett ........... 700

James Jackson ......... 80

Adam Ivie ............. 200

Thomas Jackson ......... 60

James Jones Sen ......... I I IOO

Henry Ivye $\ldots \ldots \ldots \ldots \ldots$. 450

Peter Jones ............ 62I

Ricard Jones ........... 600

Ralph Jacskon ............ I IO

Joshua Irby $\ldots \ldots \ldots \ldots \ldots, \quad 200$

John Jones $\ldots \ldots \ldots \ldots \ldots \ldots .6 .350$

6542

$\mathrm{K}$

Richard Kirkland ....... 300

John King ............. 50

Henry King $\ldots \ldots \ldots \ldots \ldots .6 .6 \%$

Arthur Kavanal. ............ 60

Ensobius King .......... I00..

I 160

\section{$L$}

John Livesley .......... 300

Samuel Lewey ............ 100

Ino Lumbady ........... 400

Jno Leeneir $\ldots \ldots \ldots \ldots \ldots$ I

Mrs Low .............. 70

Sam Lewey for Netherland Orphans ........... 498 
Thomas Lewis Sen ...... 200

Hugh Liegh ............ 762

Francis Leadbeatter ...... 100

Jno Leadbeatter ......... 400

Wm Low ............ ${ }^{1584}$

$3 \mathrm{II}_{4}$

\section{$\mathrm{M}$}

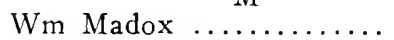

Robert Munford ..............

James Mingo Sen ..........

Matt Marks ..............

Samuell Moody ..........

Francis Mallory ..........

Daniell Mallone ...........

Jno Mayes ................

Richard More .............

Henry Mitchell Sen .......

Jno Mitchell .............

Wm Mayes ...............

Edward Murrell ...........

Thomas Mitchell Jun .....

Peter Mitchell .............

Henry Mitchell Jun .......

Francis Maberry ..........

James Matthews ..........

Jno Martin ............ 200

6839

$\mathrm{N}$

Richard Newman ....... 120

Walter Nannaley .......... 299

419

\section{$\mathrm{O}$}

Nicholas Overburry ...... 809

Jno Owen $\ldots \ldots \ldots \ldots \ldots \ldots . \quad 25$

834

\section{$\mathrm{P}$}

George Pasmore $. . . \ldots \ldots . \quad 330$

Francis Poythwes Sen .... 1283

Joseph Pattison ......... 200

George Pail ............ 246

Nathaniel Phillips ........ I50

Jno Price ............. 50

Wm Peoples ........... 150

Elizabeth Peoples ........ 235

Joseph Perry .......... 275
Richard Pigeon ......... 524

Thomas Potts .......... 200

Joseph Pritchett ........ 50

Jno Petterson ........... 373

George Pace ........... 1000

Ephram Parkam ........ 300

Thomas Poythres .......... $6 \mathrm{I}_{6}$

Dand Peoples ............ 60

Grace Perry ............ 100

Jno Poythres Jun ....... 916

Jno Petterson ........... 420

Mr Micajah Perry ....... 600

9203

$\mathrm{R}$

Jno Roberts .......... 316

Nath. Robinson .........

Roger Reace Jun ......... IOO

Henry Read ............ 75

Roger Reace Sen ......... IOO

Wm Reanes ............ 250

Frances Raye ........... 300

Jno Reeks $\ldots \ldots \ldots \ldots \ldots \ldots$. 50

Wm Rachell .............

Timothy Reading Sen .... 460

Jno Riners ............. 200

Edward Richardson ..... 300

Coll Randolph .......... ${ }_{226}$

2677

$\mathrm{S}$

Matthew Smart ......... IOO

Wm Standback ........... 150

Thomas Symmons ....... 566

James Salmen ........... 477

Wm Savage ............. 150

Wm Sandborne ......... 40

Jno Scott $\ldots \ldots \ldots \ldots \ldots \ldots \ldots, 300$

Martin Shieffield ..........

James Smith ......... 67

John Stroud .............. 60

Richard Seeking ......... 100

Wm Sexton ............. 50

James Leveaker .......... 7 10

Chichester Sturdivant .... 2I4

Daniell Sturdivant ........ 850

Richard Smith .......... 550

Jno Spaine ............. I 8 .

Matthew Sturdivant ....... I50

Capt Stith $\ldots \ldots \ldots \ldots \ldots \ldots$. $470^{\mathrm{T} / 2}$

$82721 / 2$ 
$\mathrm{T}$

Major Henry Tooker for the Merchants in London ... George Tilliman ........... Jno Tilliman .............

Wm Tomlinson ..........

Adam Tapley .............

Capt Jno Taylor ...........

Mich. Taburd .............

Maj ${ }^{r}$ Tooker ..............

Robert Tooker ............

Rolert Tester ............

Joseph Tooker .............

W'm Tempel ..............

Jno Thornhill $\ldots . . . . .$. .

Jno Taylor $. . . \ldots \ldots \ldots . .$.

Nath. Tatham Jun ........

Samuel Tatham Sen ........

Samuel Tatham Jun .......

Henry Talley ..............

Richard Turberlield ........

Francis Tucker ............

Nath. Tatham Sen ........

Jno Thrower .............

Thomas Thrower .........

James Taylor .............

Sanders Tapley ...........

Thomas Tapley ............

James Thweat Sen ........

James Thweat Jun .........

Elizabeth Tucker ..........

Thomas Taylor .............

Edward Thrower ..........

4600

446

530

400

977

1700

150

181

400

170

200

100

350

100

200

100

I95

639

140

100

501

250

150

306

300

300

715

100

212

400

150

I. 4462

\section{V}

Ino Vaughan ............

Samuel Vaugham ..........

Nath. Vrooin .............

Daniell Vaughan ............

James Vaughan ...........

Richard Vaughan ..........

$\mathrm{IVm}$ Vaughan ............

Thomas Vinson ...........

Nicholas Vaughan ..........

2163

W

John Woodlife Sen .........

644

iVm Wallis
Jno Wickett $\ldots \ldots \ldots \ldots \ldots .250$

Capt. James Wynn ....... 860

Jno Woodlife Jun ........ 750

Jno Winningham Jun ...... 200

Richard Wallpoole ....... 625

Jno Womack ........... 550

Capt Thomas Wynn ....... 400

Jno Wall ............. $\quad 233$

Thomas Winningham ..... 100

Elizabeth Woodlife ...... 844

Richard Worthern ....... 1600

Richard Winkles ......... 450

Capt Nicholas Wyatt ...... 700

Antho Wyatt ........... 250

Valentine Wiliamson ...... 250

Hurldy Wick ........... 600

IVm Wilkins ............ 900

Francis Wilkins $\ldots . \ldots . .$. I50

Robert Winkfield ........ I07

Jarvis Winkfield .......... Ioo

Henry Wall ........... 275

Jno Wilkins $\ldots \ldots \ldots \ldots \ldots$ I 50

James Williams .......... 1436

George Williams .......... 216

Jno White $\ldots \ldots \ldots \ldots \ldots$. 150

Edward Winningham ..... I00

Samuel Woodward ...... 600

I 3684

$\mathrm{Y}$

Dannell Young ........... 283

John Young $. . . \ldots \ldots \ldots, 200$

583

A $\ldots \ldots \ldots \ldots \ldots \ldots \ldots \ldots, 3217$

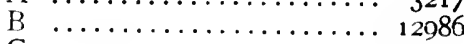

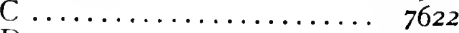

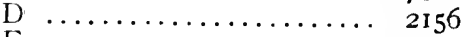

$\mathrm{E} \quad \ldots \ldots \ldots \ldots \ldots \ldots \ldots \ldots, 7243$

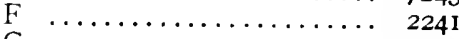

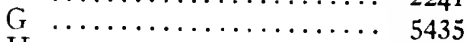

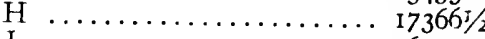

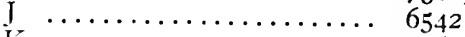

$\mathrm{K} \ldots \ldots \ldots \ldots \ldots \ldots \ldots \ldots$ I 160

$\mathrm{L} \ldots \ldots \ldots \ldots \ldots \ldots \ldots \ldots \ldots$ 5II4

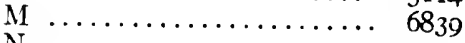

$\mathrm{N} \ldots \ldots \ldots \ldots \ldots \ldots \ldots \ldots, 419$

$\mathrm{O} \ldots \ldots \ldots \ldots \ldots \ldots \ldots, 834$

$\mathrm{P} \quad \ldots \ldots \ldots \ldots \ldots \ldots \ldots, 9203$

R $\ldots \ldots \ldots \ldots \ldots \ldots \ldots \ldots, 2677$

S $\ldots \ldots \ldots \ldots \ldots \ldots \ldots, 8272$ 


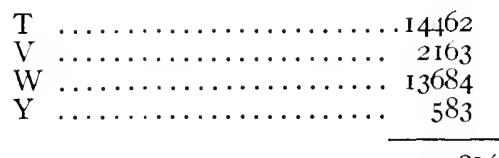

Deduct the new discovered Land .............. 10000

Accounted for

Orphans Land which is refulld paying Quit Rents for viz:

Mr. John Bannister Orphans per Stephen Cock .......

Capt Henry Batesorph and their Mother Mrs Mary

Bates

1970

1200
Capt Henry Randolph Orphans per Capt Giles Webb ................

Morris Halliham Orphans ped Robert Rivers ......

Crockson Land formerly \& who it belongs to now I cannot find

4245

I $72 \mathrm{I} 8 \mathrm{r} / 2$ acres at $24 \mathrm{lb}$ to $\mathrm{b}^{\circ}$ per Ioo is ........28I 32 lb tobacco at $5 \mathrm{~s}$ per $\mathrm{lb}$ is...... 70 66

Sallary to per cent... 7 o $10 \frac{1}{2}$

$63 \quad 5 \quad 7 \%$

per William Epes Sheriff

Rent Roll of all the Lands held of her Maj ${ }^{\text {tle }}$ In Surry County

Amno Domini I704

A

Allin Arthur Major ...... 6;80

Andrews Bartho ......... 375

Avery Jno ............. 150

Atkins Thomas ......... 80

Averett Jno ........... I 20

Atkinson Richard ........ I00

Andrews Thomas ........ 190

Andrews Robert ......... I30

Andrews David ........... 225

$8 \mathrm{I} 50$

\section{$\mathrm{B}$}

Baker Henry Coll $\ldots \ldots \ldots \ldots$
Bruton James ..............

Bennett James ............

Bland Sarah ..................

Browne Jno .............

Benbridge George .........

Bighton Richard ..........

John Bell .................

Berham Robert ...........

Blake $\mathrm{Vm}$................

Browne Edward ............

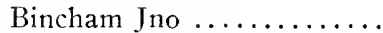

Bennett Richard ...........

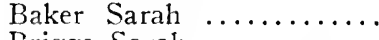

Briggs Sarah ..............

Baxter Joell
Briggs Samuel ......... 300

Blico Christopher ....... 50

Brigs Charles ........... 331

Brigs Henry ........... IOO

Bentley ............... I80

Blackbun Wm ............ 150

Blunt Thomas .......... I355

Bookey, Edward ......... I80

Browne Wm Coll ........ 2510

Browne Wm Capt ....... 398

Bineham James ......... I57

Bullock Mary ............ IO

Barker Jno ............. II6o

Bagiey Peter ........... 100

Barker Jery ............. 420

Bunell Hezichiah ......... I50

Bougher Phill .......... I0o

Baile Jno ............. 250

Bagley Edward ......... 350

I47I6

C

Chapman Benjamin ..... 500

Cockin $\mathrm{Wm}$............. IOO

Cocker Jno ........... 900

Crafort Robert .......... I000

Crafort Carter ........... 100

Chambers Wm ............ 50

Clark Jno ............ I00 
Cook Elizabeth ...........

Carriell Thomas ..........

Clements Jno .............

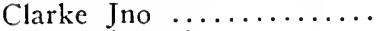

Cook Elizabeth ............

Carriell Thomas ..........

Clements Ino ............

Clark Robert .............

Checett James ...........

Cotten Walter .............

Cotten Thomas ...........

Collier Jno ..............

Collier Joseph ............

Cock Wm ...............

Cock Walter .............

Cooper James ..............

Cleaments Francis .........

Collier Thomas ...........

Candenscaine Obedience ..

D

Dicks James ........... 400

Davis Arthur .......... 460

Drew Thomas .......... 800

Drew Edward .......... 600

Delk Roger ........... 790

David Arthur ........... 50

Dean Richard .......... I00

Davis Nath. .......... $\quad$ I57

3357

$\mathrm{E}$

Edward Wm Mr. ....... 2755

Evans Antho ............ IOO

Edward John ............. 470

Ellitt Wm ............. 250

Edmund Howell ........ 300

Ellis James ............. I80

Edmund $\mathrm{Wm} \ldots \ldots \ldots \ldots$ I 100

Ellis Edward ........... 30

Ellis James ........... 170

Ezell Geirge .......... 150

Ellis Jere ............. 50

Evans Abrah. .......... 150

4705

F

Flake Robert ........... 200

Foster Anne ........... 200
Ford George ........... 100

Flood Walter ........... 820

Flood Thomas ........... I50

Ford Elias ............ 200

Flemin Lawrence ........ 360

Foster Christo ......... 500

Foster $W_{1 n} \ldots \ldots \ldots \ldots \ldots$........ 100

Ferieby Benj .......... I70

G

2800

Gray Wm Capt ......... $\quad 1750$

Gray Wm Jun .......... I050

Grines Austis .......... I00

Gwalney $\mathrm{Wm} \ldots \ldots \ldots \ldots \quad 400$

Gray Jno .............. 200

Gwalney Wm .......... 225

Goodman $V_{\mathrm{m}} \ldots \ldots \ldots \ldots .200$

Gillham Hinche ......... $65^{8}$

Griffin John ........... 200

Gully Richard .......... 50

Gray Wm ............ I0

Green Edward .......... 200

Grecn Richard .......... 260

$\mathrm{H}$

Harrison Benj Coll ...... 2750

Harrison Nath. Capt ..... 2177

Hunt Wm ............ 4042

Holt Elizabeth ......... 1450

Holt John ............. I50

Holt Thomas Capt ........ 538

Holt $\mathrm{Wm}$............. 630

Harris $\mathrm{Wm}$........... 150

Hart Henry ........... 725

Humfort Hugh ......... 150

Hancock John ............ 60

Hart Robert ........... 600

Humphrey Evan ......... 70

Hollyman Mary ........ 290

Harde Thomas .......... 900

Hill Robert ............ 200

Holloman Richard ....... 480

Hargrove Bryan ........ $\quad 100$

Hunifort IVm .......... 50

Hill Lyon ............. 300

Holloman Thomas ....... 450

Heath Adam ........... 200

Harrison Daniell ........ 70

Ham Richard ........... 75

Heart Thomas .......... 750 


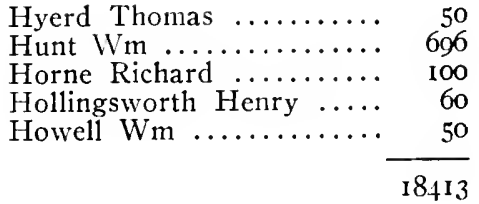

$\mathrm{J}$

Jackman Jos Jolin Mr. ... 2980

Jones James ........... 1000

Jarrell Thomas ......... II

Jarrett Cliarles ........... 6I5

Judkins Samuell ......... I00

Judkins Wm ............ 100

Jurdan George ........... 620

Jarrett Fardo ........... 630

Johnson Wm ........... 360

Johnson John .......... 350

Jurdan Richard ........ 350

7220

$\mathrm{K}$

Kigan Mary ........... 200

Killingworth Wm ....... 60

Knott Wm ........... 300

560

$\mathrm{L}$

Ludwell Philip Coll ...... 1100

Lancaster Robert ......... 100

Lacey Mary ............ 100

Lang Mary ............ 77

Lane Thomas .......... 200

Lane Thomas Jun ....... 200

Laughter Jno ........... 300

Laneere George ......... 300

Lasley Patrick .......... 520

Lucas Wm ............ 315

3212

\section{M}

Matthew Edmund

Merriell George ......... 250

Moorland Edward ........ 225

Mason Elizabeth ......... 300

Mallory Francis .......... I47

Merrett Matt. .......... 60

Middleton Thomas ....... 100
Moss Wm ............... I00

Moreing John .......... 695

Mierick Owen ......... 250

2177

$\mathrm{N}$

Newton Wm ............ 225

Newton Robert ......... 250

Newitt Wm ........... 330

Norwood Richard ....... 80

Nicholl George .......... 150

Nichols Robert ......... 230

Noeway Barefoot ........ I $\quad$ I50

Norwood George ....... 330

1745

$\mathrm{P}$

Park Mary ............ 100

Pittman Thomas Jun ..... 100

Pliillips, John .......... 270

Price John ............. 340

Pettoway Elizabeth ...... 650

Pulystone Jno .......... I400

Parker Richard ......... 269

Phelps Humphrey ....... 100

Pully Wm ............ 300

Procter Joshua ........ 660

Persons John ........... 830

Phillips $\mathrm{Wm} \ldots \ldots \ldots \ldots \ldots . .300$

Pettfort Jno ........... 200

Pettfort Wm ........... 50

5569

$\mathrm{R}$

Randolph Wm Coll ...... 1655

Ruffice Elizabeth ........ 300 I

Reynolds Robert ......... 150

Richardson Joseph ....... 300

Reynolds Elizabeth ...... 150

Reagon Frances ........ 200

Roads Wm ............. I $_{50}$

Rolling George ........... 106

Road Wm .............. $45^{\circ}$

Rose Richard ............ I00

Raehell George .......... 70

Rowling Jno ............ 476

Rohings Wm ........... 596

Roger Wm ............ 450

7854 
$\mathrm{S}$

Scat Joseph ..........

Sims George ...........

Secoms Nicholas ........

Savage Charles .........

Stringfellow Richard .....

Suger Jno .............

Sewurds Amne .........

Sharp Thomas .........

Sewins Thomas ........

Steward John .........

Smith Richard .........

Savage Mary ...........

Smith Thomas ........

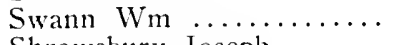

Shrowsbury Joseph ......

Shrowsloury Francis .....

Savage Henry ..........

Short IIm ............

Scarbro Edw ...........

Scagin Jno ...........

Simmons Jno .......... I300

Shrowsbury Thomas ..... 566

Stockly Richard ......... Ioo

Smith Thomas ......... 380

10237

T

Thompson Samuell ...... 3104

Tooker Henry Major .... 700

Taylor Ethelred ....... 5.38

Thorp Joseph ......... 250

Tyous Thomas ......... foo

Taylor Richard ........ 77

5060

Vincent Mary $\begin{gathered}\mathrm{V} \\ \mathrm{V}\end{gathered}$

II

Wright Thomas ......... In

Williams Charles ........ I00

Mall Joseph ........... I 50

Williams $W_{1 n} \ldots \ldots \ldots \ldots \ldots .300$

Nard Thomas .......... I00

IVall Ioseph Jun ........ I50

Warren Allen ......... 300

W'arren Thomas ........ iofo

Watkins Richard ........ 1.345

Williams Roger ........ I50
1Vebb Robert .......... 340

Wattkins John .......... I I60

Narren Robert ......... I 50

Vielch Henry ........... I00

Warrick John ......... 80

Milkinson Matthew ...... 200

II iggins Thomas ....... 300

Viaple Jno ............ 300

Vitherington Nicholits ... I I

llill Koger ............. 78

IVhite Charles ......... I36

6679

1

Young John .......... 300

$\triangle \ldots \ldots \ldots \ldots \ldots \ldots \ldots 8_{150}$

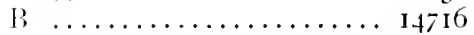

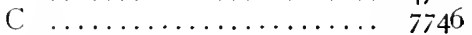

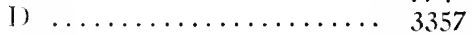

li $\ldots \ldots \ldots \ldots \ldots \ldots \ldots \ldots \ldots+4705$

$\mathrm{F} \ldots \ldots \ldots \ldots \ldots \ldots \ldots \ldots \ldots$

( $\ldots \ldots \ldots \ldots \ldots \ldots \ldots \ldots \ldots \ldots \ldots \ldots \ldots$

$\mathrm{H} \ldots \ldots \ldots \ldots \ldots \ldots \ldots \ldots \ldots \ldots \ldots$

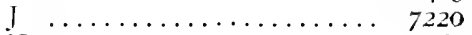

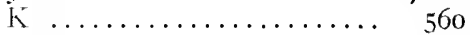

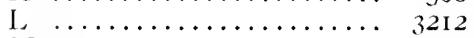

M $\ldots \ldots \ldots \ldots \ldots \ldots \ldots \ldots 2177$

$\aleph \ldots \ldots \ldots \ldots \ldots \ldots \ldots \ldots \ldots \ldots$

P $\ldots \ldots \ldots \ldots \ldots \ldots \ldots \ldots 569$

R $\ldots \ldots \ldots \ldots \ldots \ldots \ldots \ldots \ldots \ldots$

S $\ldots \ldots \ldots \ldots \ldots \ldots \ldots$ IO 237

T $\ldots \ldots \ldots \ldots \ldots \ldots \ldots \ldots \ldots 60 \ldots \ldots$

$\checkmark \quad \ldots \ldots \ldots \ldots \ldots \ldots \ldots \ldots$ I 87

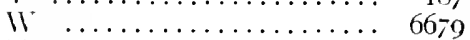

$Y \ldots \ldots \ldots \ldots \ldots \ldots \ldots$

I 16089

New Land allowed per order $384 \mathrm{I}$

Aprill inth izo5

I 1248

Errors excepted per

Jos Jno. Jackman Sheriff.

Persoms denying payment for Lands held in this County (viz) Capt Tho Holt as belonging to Mr. Tho

Benules Orphans ...... 950

Mrs. Mary Whitc ..... 200 
Lands held by persons living ont of the Country

Capt Jno Taylor ........ 850

Mrs. Sarah Low .......... 500

Mr. Ino Hamlin ........ Ioo

Capt Thumale Hatrison $\ldots . .530$

II 50

3130
Bartho Clement one tract of Land he living in England the quantity unknowne

Juo Davis one Tract Living in Isle of Wight

Greo \& River Jorden one Tract \& deny's to pay $Q$ t Rents for it \& no persons living thereon, there is one Bray Living in Warwick has a small tract Land

A List of her Majess $Q^{t}$ Rents For the Isle Wighte County in the

Year $1 ; 04$

Jno Akins

James Mthinson

fimes Atkinson ...........

IIm Exam $\ldots \ldots \ldots \ldots \ldots$

Fram brown ..............

Richard bennett ..........

James Briggs ...........

Ph. Bratley ...............

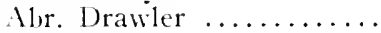

Jno Branch .............

lirancis Branch $\ldots \ldots \ldots \ldots$

Edward Brantley .........

John Brantly ...........

Edward Boykin ............

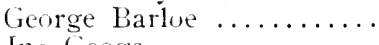

Jno Geoge ..............

Thomas Carter ............

Reubin Cooke ............

Jno Clarke ..............

Thomas Cook ...........

Wm Clark ..............

Edward Champion ........

Jno Dowles ..............

Peter Deberry ............

Thomas Davis ............

Jno Daris ..............

Peter Hayes .............

Christo. Hollyman .......

Richard Hardy ...........

Thomas Holyman ........

Ino Harris .............

Silvester Hill .............

Roger Hodge ............

Arthur Jones ..............

Edward Jones ...........

Richard Jones ...........

Jno Johnson .............

Roger Ingram
200

$+100$

I 140

150

200

7o

$\mathrm{IOO}$

200

200

45

50

175

364

I 100

So

200

700

250

850

300

600

600

I 50

IOO

$\mathrm{I} O \mathrm{O}$

250

600

400

700

I 50

365

925

300

900

250

250

890

300
Matt. Jorden ............ I950

Thomas Newman ........ 360

George Readich ......... zyo

Francis Lee ............ Ioo

Pl. Pardoe ............

Jno Parsons ............ I 155

George Moore .......... 400

Jno Mangann .......... I00

Robert Mongo .......... too

Henry Martin .......... 200

Jno Murray ........... 650

Francis Raymer ......... 8o

Jno Richardson .......... I50

James Sampson ......... I 200

Jno Stevenson .......... I50

Thomas Sherrer ........ 200

Jno Sherrer $\ldots \ldots \ldots \ldots \ldots, 200$

W'm Thomas ........... 250

Thomas Tooke ......... I 228

Thomas Throp ........ 350

Baleaby Terrell .......... I00

Peter Vasser ............ 230

Jno IVilliams ........... 600

George IVilliamson ....... 2735

Fra. Williamson ........ 2035

Thomas Wood .......... 50

James Lipe ............ 45

Elizabeth Reynolds ....... Io

Jno Sojonrner .......... 240

Robert Hoge ............ 60

Andrew Woodley ......... 770

Arthur Allen ............ 1800

Henry Baker ........... 750

Rubin Prochter ......... 250

Thomas Howell .......... I00

Nath Whitby ............ I70

Jane Atkins ............... 600

Jno Mongo ............. I0 
Natt Ridley ............ 200

Jno Bell ............. 200

Wm West ............. 250

Charles Goodrich ........ 8o

Jno Britt ............. 350

Ino Barnes ..............

Henry Goldham ..........

Jno Waltham ............

Charles Edwards ..........

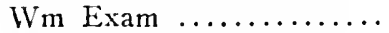

Major Lewis Burwell .....

Henry Applewaite ........

Thomas Pitt .............

Jno Pitt ...............

Mary Benn ..............

Robert Clark .............

Antho Holliday ...........

Wm Westrah .............

Elizabeth Gardner ........

Jno Gardner ..............

Jno Turner ..............

Antlio Foulgham .........

Anne Williams ...........

Edward Harris ...........

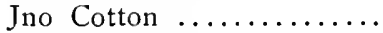

Thomas Joyner...$\ldots \ldots$.

Jno Lawrence ............

Thomas Mandue ..........

Wm Mayo ...............

Jno Garcand ...............

James Bryan .............

Wm Keate ...............

Jno Browne ................

Francis Sanders ..........

John Rogers .............

Hodges Councie ..........

Hardy Councic ...........

Jno Councie ..............

Thomas Reeves ..........

Wm Crumpler ............

Bridgeman Joyner .........

Elizabeth Swan ...........

Thomas Jones ............

Arthur Whitehead ........

Thomas Allen ...........

Jerimiah Exam ..........

Nicholas Casey ..........

Jno Giles $\ldots \ldots \ldots \ldots \ldots$.

Alexander Camoll ........

Jno Rutter .............

Godfrey Hunt ...........

$\mathrm{Wm}$ Trygell .............

Benj Jorden .............
Thomas Jorden ..........

Jno King ................

Wm Wilkinson ...........

Thomas Grace ...........

Wm West ..............

Jno Penny ..............

Robert Richards ..........

Thomas Northworthy .....

Fra Parker ...............

Widdo Long ............

Trustram Northworthy ....

George Green .............

J110 Druer ..............

Philip Peerce ...........

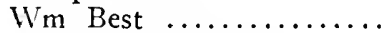

Humphrey Marshall ......

Thomas Brewer ..........

IVm Smith $\ldots$

Samuel \& Wm Bridger .... I2900

Wm Williams .......... I00

Richard Ratcliffe ........ 380

Joshua Jordan .......... I50

Daniall Sandbourne ...... I 80

Nicholas Houghan ....... 780

Mary Marshall ......... 200

Joseph Godwin ......... 250

Joseph Bridger .......... 580

Henry Pitt ............ 700

James Baron ........... 300

Arthur Smith .......... 3607

Robert Broch ........... 400

Wm Godwin ............ 400

Hugh Bracey ........... I000

Henry Turner .......... 350

Thomas Wootten ......... 963

Richard Reynolds Esq ...... 853

Richard Reynolds ........ 746

Jno Parnell ............. 400

Benj Deall .............. 467

Thdo. Joyner ............ 595

Jno Jordan ............. I0

Henry Wiggs ........... 506

Wm Body ........... 1375

Arthur Purcell ............ 750

Jno Portel1s ............ I00

Wm West .............. 690

Simon Everett ........... I 100

Walter Waters ...........

John Jordan .......... 150

John Nevill ............ 433

Robert Colman .......... ${ }_{1500}$

Wm Green .............

Mary Cobb .............. 150 
Robert Edwards ..........

Anne Jones ...............

Abraham Jones ...........

John Jones $\ldots \ldots \ldots \ldots \ldots$.

Richard Lewis ............

Henry Dullard ............

Thomas Williams .........

James Mercer ............

Poole Hall ...............

Jno Howell .............

Thomas Lovett ...........

George Anderson ..........

Daniell Nottiboy ...........

Henry Wilkinson ...........

Jno Watkins ............

Thomas English .........

Thomas Page ...........

Francis Davis .............

Richard Braswell ........

Robert Johnson ...........

Jno Minshea ............

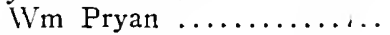

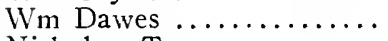

Nicholas Tyner ..........

Isaac Ricks .............

Robert Scott .............

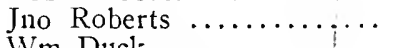

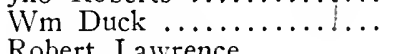

Robert Lawrence ........ 400

Jno Denson ............ 200

Robert Smelly ............ 600

Francis Bridle ........... 250

Roger Fearlton ......... 237

Thomas Bullock ......... IOO

Wm. Marfry ............ 600

Thomas Powell .......... I00

Widdo Glyn ........... 390

Jno Pope ............. 250

Thomas Gayle ......... 200

Wm Powell ............ 200

Richard Hutchins ........ 300

Henry Boseman ......... 100
Henry Pope ........... 557

John Williams ......... $97 \mathrm{I}$

Henry Sanders ......... 700

Jno Selloway .......... 900

Jno Bardin ............. 100

Phill Rayford ............ 650

Phill Pearse ............ 500

Jno Terseley ............ I50

Geo Northworthy ......... I I 66

Robert Richards ......... 450

Thomas Bevan .......... I00

Wm Hunter ............ I50

Madison Street .......... I50

Thomas Wheatley ...... 400

Richard WVilkinson ....... I50

James Bragg...$\ldots \ldots \ldots$.... 500

Jno Portous ............ 300

Thomas Harris ......... 350

Edward Harris ........... I00

Nicholas Askew ......... 80

Ambrose Hadley ......... I00

Widdo Powell .......... 480

Thomas Jones .......... I00

Thomas Underwood ...... I0

Robert King ........... 300

Thomas Giles ............ 880

Lewis Smelly ........... 550

$\mathrm{Wm}$ Smelly ............ 280

Godfrey Hunt ........... 600

Edmund Godwin ......... 400

Wm Williams .......... 1000

John Wilson ........... 1200

John Bryan ........... 200

John Askew ........... I00

Samuell Bridger ......... 200

Roger Nevill ............ 200

Coll Godwin ............ 600

Jacob Durden .......... 500

Wm Bridger.

A Compleat List of the Rent Roll of the Land in Nansemond County In Anno I704

John Murdaugh $\ldots \ldots \ldots, \quad 300$

Jno Duke ............... I1 3

Thomas Duke Jun ........ 930

Edward Roberts ......... 250

Paul Pender ............. 240

Thomas Duke .......... 400

James Fowler ........... 440
Robert Baker $\ldots \ldots \ldots \ldots \ldots$....... 50

Isaac Sketto ............. I00

Edward Sketto ............. 200

Antho Gumms ........... 50

Francis Sketto ........... I00

Wm Parker ............. 100

Francis Parker ......... 170 
Thomas Parker ..........

Jno Small .............

Moses Hall ...............

Edward Beamond .........

Richard Parker ..........

Capt James Jessey ........

$11 \mathrm{~m}$ Sanders ...........

Jno Sanders ..............

Thomas Mansfield ........

$11 \mathrm{~m}$ Woodley .............

Andrew Bourne ..........

Gilbert Owen ............

Wm Sanders Jun .........

Capt John Speir .........

Capt James Reddick ......

James Griffin ............

Nicholas Stallings ........

John Stallings ..........

Richard Stallings .........

Elias Stallings Jun ........

Joseph Baker .............

$11 \mathrm{~m}$ Jones ..............

Robert Roundtree ........

John Roundtree .........

George Spivey ...........

James Spivey ............

James Kinight ............

J no Gorden .............

Edward Arnold ...........

James Mulleny ............

Thomas Docton .........

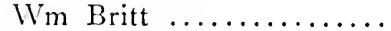

Nath Newby ...............

Elias Stalling ..............

Robert Lassiter ............

Patrick Wood ............

$\mathrm{Wm}$ Thompson ...........

Jonathan Kitterell ........

Alam Rahey ............

Ino Powell ..............

John Reddick ............

Henry Copeland ..........

Thomas Davis ............

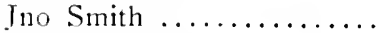

Thomas Harrald .........

Richard Baker ............

Samuell Smith ..............

$\mathrm{Wm}$ Hood ................

Thomas Roundtree ........

Henry Hill ................

Jno Larkhum .............

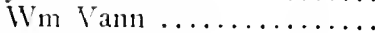

Joseph Cooper ...........
300

IOO

95

$55^{\circ}$

$5 \mathrm{I} 4$

550

200

165

60

$35^{\circ}$

200

I 20

I0 5

500

$9+3$

500

965

250

165

250

740

500

245

475

200

600

300

330

80

500

200

400

850

470

850

200

I 33

300

5.6

758

300

I 50

250

IOO

652

40

230

200

350

I 75

500

I 00

267
John Harris ...........

Francis Copeland .........

Elizabetl Price ............

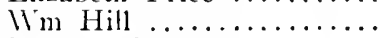

Thomas Spiver ..........

Jno Campbell .............

Jno Morley ..............

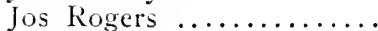

Jno Cole ...............

Thomas Harrald ..........

Christopher Gawin Jun ...

Daniell Horton ..........

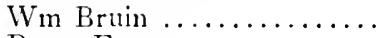

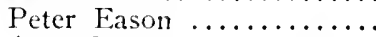

Anne Pugh ..............

Benj Blanchard ...........

Thomas Norfleet .........

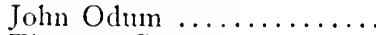

Thomas Gough ..........

Hugh Gough ...........

Epapap Boyne ............

Henry Baker ............

Christopher Gwin .......

James Speirs ...........

Epaphra Benton ..........

Wm Eason ..............

Andrew Brown .............

IIm Horne ..............

Rohert Reddick ...........

Henry Hackley ............

Thomas Roberts .........

Abr. Reddick ............

Jno Parker ................

Richard Barefield ..........

John Benton ...............

Ino Pipkin $\ldots \ldots \ldots \ldots \ldots$.

Ios Brady .................

Christopher Dudley .......

Thomas Norris ..........

Thomas VIiggins .........

Patrick I awley .............

Robert Marren ............

Richard Odium ...........

Thomas Davis ...........

Thomas Barefield ..........

John Eason ................

Jerimiale Arlin .............

Jno Perry ............

Ino Drury $\ldots \ldots \ldots \ldots \ldots$

Joseph Booth ............

Cresham Cofield ..........

Richard Sumner ..........

Edward Norfleet ..........
600

$5^{\mathrm{I}} 3$

I 50

I 50

200

400

100

I 5

814

100

20

200

300

400

2300

I 30

500

50

I 50

I 50

IOO

375

IOIO

200

250

IBO

25

100

200

2 IO

30

400

240

900

660

IOO

250

200

100

100

50

IOO

50

340

IOO

I 50

250

870

87

987

350

600

200 


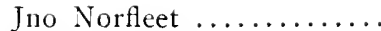

Edward Moore ............

Thomas Moore ..........

James Lawry ...........

James Daughtie ..........

John Wallis ..............

Richard Sanders Jun .....

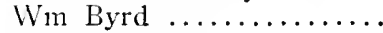

James Howard ...........

John Brinkley .............

Robert Horning ..........

Wm Speirs .............

Sarah Exum .............

Jno Larrence .............

Nicholas Perry ..............

Sampson Merridith .......

Coll Thomas Milner ........

Joseph Merridith .........

Thomas Kinder ..........

Henry King ...............

Joseph Hine .............

Wm King ..............

Julian King .............

Mich. King .................

Capt Tho Godwin J . . . . . .

Henry Lawrence ..........

Jno King ................

Richard Hyne.$\cdots \ldots \ldots \ldots$

Capt Francis Milner ......

Benj Nevill ..............

Elizabeth Marler ..........

Wm Keene .................

Jno Symmons .............

Hen : Johnson .............

Jno Darden .............

Wm Everett ..............

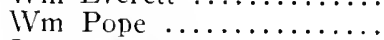

Joseph Worrell ..........

Thomas Jemegan Jun ......

Richard Lawerence .......

Jonathan Robinson .......

Robert Yates ............

Thomas Odium ..............

John Barefield ..............

John Ranles ..............

Thomas Boyt .............

Thomas Vauglian ..........

Jno Parker ................

Richard Green ..............

Elizabeth Batlard ...........

Samuell Watson ...........

Francis Spight ..............

Joseph Ballard ...........
600

250

200

40

400

I 50

100

300

700

$+30$

80

200

150

175

200

400

1484

250

160

300

I 50

I 40

700

80

697

200

1000

200

479

$+75$

80

200

678

I 50

500

I 50

890

270

135

200

400

150

20

300

600

400

200

300

200

300

200

400

200
John Oxley ........... I00

Benj. Rogers ........... 6oo

Robert Rogers .......... 300

Henry Jerregan ......... 200

Jno Hansell ............ 500

Henry Jenkins ........... 400

Capt William Hunter .... 800

Jno Moore ............ 200

Richard Moore ......... 250

Edward Homes ......... 300

Fra. Cambridge .......... ICO

Wm Ward ............. 200

Ino Rice ............... I

Wm Battaile ........... 800

VIm Spite ............. 500

Alor. Oadham ........... 20

Jacob Oadam ........... 20

Jno Lee...$\ldots \ldots \ldots \ldots$......

iVm Macklenny ......... 200

Robert Coleman ......... I 400

Jno Bryan ............ 200

Wm Daughtree ........... Ioo

Jno Copeland ........... Goo

fno Butler ............. 200

James Butler ............ 75

Thomas Roads ........... 75

$\mathrm{Wm}$ Collins ............ 1220

Jno Hedgpath ...........

Jno Holland .............

Robert Carr ........... 200

$1 \mathrm{Im}$ Waters ............ 600

Robert Lawrence ......... 400

$\mathrm{Wm}$ Bryon ............. 350

Lewis Bryon ............. 400

James Lawrence .......... I0

W'm Gatlin ..............

Joseph Gutchins .......... 250

George Lawrence .......... too

Lewis Daughtree $\ldots . . . \ldots$. 100

Thomas Rogers .......... 50

Ino Rogers ........... 200

Henry Core ............ 50

Edward Cohb ...........

Richard Taylor ........... 300

Robert Brewer ........... 200

Wm Osburne $\ldots \ldots \ldots \ldots \ldots, 200$

Thomas Biswell .........

Jno Gatlin .............. 200

Richard Folk ............ I00

Thomas Parker ..........

Peter Parker ............... 1 I.

IVm Parker .............

Richard Hine Jun ....... 200 
Steplien Archer ...........

Charles Roades ..........

Henry Roades ...........

James Collings ...........

Henry Holland .............

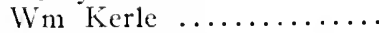

Joseph Holland ...........

Jno Thomas Jun ..........

Jno Thomas ..............

Thomas Mason ...........

Edward Mason ...........

Jno Sanders ............

Mich Brinkley ............

James Moore ............

Henry Blumpton .........

Jno Symmons ............

Jeremiah Edmunds ........

John Gay ...............

Philip Aylsberry ..........

James Copeland ..........

Jno Brothers ............

Richard Creech ...........

Richard Bond ..............

Thomas Handcock ........

James Knott .............

Wm Edwards ............

Robert Elkes .............

Edward Price .............

Jane Belson ..............

Wm Staples ..............

Robert Mountgomery .....

John Moore ...............

Capt Edmund Godwin .....

Thomas Wakefield ........

Godfrey Hunt ...........

Henery Wilkinson ........

Nicholas Dixon ..........

George Keeley ...........

Richard Taylor ...........

Anne Coefield .............

Joseph Hollyday ...........

Mr. Jno Braisseur ........

Thomas Best ............

Alexander Campbell ......

Capt Charles Drury .......

Thomas Drury ..............

Luke Shea ..............

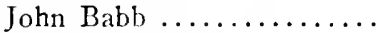

Abraham Edwards .......

Richard Sanders ..........

Antho Wallis .............

Daniell Sullivan ..........

Joseph Ellis ..............
200

800

100

300

400

325

100

100

275

350

150

150

200

400

1500

I00

70

200

I 00

390

460

200

90

30

1050

I 50

175

I 40

IOO

210

I 50

100

800

I 50

360

250

200

650

300

300

1000

400

I6o

500

570

65

500

400

500

80

100

290
Nicholas Hunter .........

Richard Webb ............

John Hare ..............

Christopher Norfleet ......

Jno Heslop .............

Francis Benton ...........

Capt Wm Sumner ........

Elizabeth Syrte ............

Anne Hare ..............

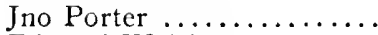

Edward Welsh .............

Jno Winbourne ............

Paul Pender ..............

Mich Cowling ............

John Cowling ...........

Rowland Gwyn ............

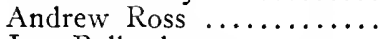

Jno Ballard ..............

Benjamin Montgomery ....

Thomas Corbell ..........

Jno Yates..$\ldots \ldots \ldots \ldots \ldots$

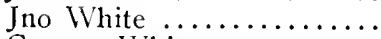

George White .............

Jno Bond ..............

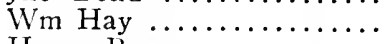

Henry Bowes ............

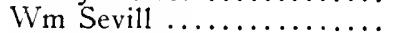

Jno Hambleton ...........

Robert Jordan ............

Tames Howard .............

Ruth Coefield ..............

Jno Chilcott $\ldots \ldots \ldots \ldots \ldots$

Jno Rutter .................

Thomas Rutter ............

Wm. Rutter ................

Capt Barnaby Kerney ......

Thomas Cutchins .........

Robert Lawrence ...........

Samuell Cahoone ............

Jno Iles .................

Thomas Sawyer ............

Wm Outland ..............

Coll George Northworthy..

Coll Thomas Godwin ......

Caleb Taylor ...............

Thomas Carnell ............

Richard Bradley .............

Jno Corbin ..............

Wm Sykes .................

Major Thomas Jorden ....

Richard Lovegrove ........

Thomas Davis ..............

Samuell Farmer ............
190

200

I 90

400

148

200

275

100

600

450

100

400

200

IOO

100

75

I 50

400

910

200

400

I 50

50

I 50

100

600

85

200

850

25

I IO

100

80

75

75

460

I 50

I 30

240

220

I80

400

650

810

200

320

250

300

I 50

700

I5O

144

160 
Henry Bradley ......... 500

Jno Clarke .............

Margarett Jorden ..........

Wm Elkes ..............

Humphrey Mires .........

James Ward .............

Widdow Hudnell ..........

Wm Grandberry ..........

Israell Shepherd ..........

Benj. Small ..............

Anne Crandberry ...........

Charles Roberts ..........

Richard Sclator ..........

Robert Murrow ..........

Elizabeth Peters ..........

Thomas Jones ............

Elizabeth Butler ..........

Coll Samuell Bridger .......

Jno Lawrence ...........

Thomas Jarregan .........

Thomas Jarregan Jun .....

Wm Drury ..............

Wm Butler ................

Henry Jenkins ............

Edward Bathurst ...........

Thomas Houffler ...........

Edward Streater ...........

Wm Duffield ..............

Charles Thomas Jinn .......

Jno Blessington ...........

Ursula Goodwin ............

Thomas Acwell ...........

Wm Peale ................

John Lambkin .......... 50

300

200

100

75

50

300

320

334

200

200

500

100

165

440
James Murphice ........ 160

Robert Peale ........... 275

John Peters ............. 368

James Peters ........... 340

Joln Wakefield ......... 50

Richard Wynn .......... 890

James Lockhart .......... 800

John Keeton ............ 2000

600

So

120

860

250

200

200

50

50

I 50

100

180

I 17024

Jno Murrow .......... 200

Added to make up equll $\quad 13850$

the last year list

which may be supposed 131074

to be held by persons

that have not made both

Persons living out of the County and other that will not pay or give account. Viz:

Capt Thomas Lovett

Capt Jno Wright

Fra Parker Jun

Tho Martin

Jno Wright

Wm Lapiter

Jno Lapiter

Capt Luke Haffield

Mrs Elizabeth Swann

Errors excepted per me

Henry Jenkins

An Alphabetical List of the Quit Rents of Norfolk County I 704

Ashley Dennis .......... I50

Avis Widdow ........... 50

Adam Wm ............. IOO

Alexander John ......... 300

Barington $\mathrm{Wm}$........... 100

Bartee Robert .......... I50

Bull Robert Sen ......... 1050

Blanch Wm ............ I00

Bond Wm ............. 200

Brown Widdow .......... 270

Bruce Abraham ......... I010

Brown Wm ............ 100

Bowers Jno ............ I66

Bolton Wm ............ 212

Byron Roger ........... 200
Bayley Walter .......... 290

Bruce Jno ............ 300

Bishop IVm ........... I00

Bull Henry ............ I500

Bucken Wm ............ 410

Babington Thomas ....... I 50

Babington Jno .......... I50

Babington Rich ......... 50

Burges George .......... 200

Burges Robert .......... 535

Butt Richard ........... I840

Brown Edward .......... 300

Bigg Thomas .......... 100

Balingtine Alexander ..... 300

Balengtine George ........ 5 I0 
Bull Thomas .......... 2200

Bramble Hestry ......... 100

Blake Arthur ........... 200

Bolton Richard ......... 700

Branton John .......... 330

Bacheldon Joseph ....... 300

Bush Samuell Major ..... I6_S

Balingtine $11 \mathrm{~m}$......... bo

Bowles Henry ......... 330

Cartwright Peter ......... I050

Cooper $11 \mathrm{~m} \ldots \ldots \ldots \ldots$ I .......

Cooper Ino ............ I50

Cramore George ......... I00

Carling Walton .......... 50

Carling Joseph ......... 200

Curch Richard .......... I050

Churey Widdow ......... 500

Cuthrell Going ......... 470

Crekmore Edward ........ \oo

Cartwright Widdow ...... 800

Corprew Jno .......... 650

Corprew Thomas ........ 650

Crekmore Jno .......... 750

Caswell Widdow ......... 350

Colley Jno .............. 100

Cottell Thomas ......... 200

Conden Thomas ......... 390

Conner Lewis ......... 2200

Carney Jno ............ 100

Carney Richard ......... I00

Collins $\mathrm{Wm}$............ 100

Crekmore Edmund ........ 690

Charleton Jno .......... 50

Cutrell Thomas ......... I50

Chapman Richard .........

Churey Thomas ..........

Churey Jno ..............

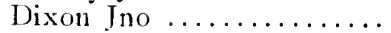

Davis W Wm Sen ...........

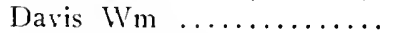

Dresdall Rolert ..........

Davis Thomas ............

Desnall $\mathrm{Wm}_{\mathrm{m}} . . . \ldots \ldots \ldots . . .$.

Davis Edward ............

Dalley Henry ..............

Dalley $\mathrm{Wm}$.................

Davis Thomas ............

Denby Edward ...............

Daniell Hugh .............

Etherdge Thomas Cooper..

Etherdge Thomas B R ...

Etherdge Thomas Sen .....

Etherdge Thomas Jun ....
Etherdge Edward .........

Etherdge $1 \mathrm{Vm} \ldots \ldots \ldots \ldots .250$

Etherdge Wm Jun ....... so

Etherdge Marmaduke .... 525

lidmonds John .......... 50

Ellis $\mathrm{Wm} \ldots \ldots \ldots \ldots \ldots .200$

Etherdge Edward Cooper .. 200

Estwood Thomas ....... I7o

Estwood John ........... 75

Etherdge Edward Sen .... 33

Edwards John .......... 250

Etherdge Charles ......... 75

Evans Abrigall .......... I00

Furgison Thomas ........ I00

Freeman Jno ........... I90

Foreman Alexander ...... 750

Foster Henry ........... 1000

Ferbey Jno ............. 500

Fulsher Ino ........... I396

Godfry liaren .......... 350

Godfry John ............ I 1470

Godfry Mattlew ........ 450

Grefen Ino ............. 200

Garen Daniell ........... 50

Guy John ............. I

Gwin $\mathrm{W} m$............ 350

Gilhgun Ferdiuando ....... ${ }_{182}$

Gilhgan John .......... 200

Gresnes James .......... 150

Gaines John ........... 50

Guy James ............ I00

Herbert Thomas ......... I50

Hayes $\mathrm{Wm}$............ 200

Harris John ........... I Io

Holyday Jno ............ 440

Hodges Joseph .......... 50

Hoges Thomas .......... 407

Hoges John ........... 520

Hollowell Jno Sen ........ 524

Hollygood Thomas .......

Hollowell Jno ........... 200

Holsted Henry ............ 633

Hollowell Joseph ......... I 280

Holsted Joln ......... 350

Hues Edward ........... I304

Hullett Jno ........... 300

Hodges Roger ........... 109

Hodges Thomas ........ 50

Hodges Richard ......... 375

Harvey Richard ........... 265

Handlberry ............. 300

Hollowell Elener ......... 1550

Herbert Jno ........... 400 
Hargrave Benjamin ...... 250

Hartwell Richard ......... I50

Henland Ino ............ 800

Ivey George ........... 496

Jackson Symon ......... 720

Ives Timothy $\ldots \ldots \ldots \ldots .400$

Ives Timothy Jun ....... I00

Ives John ............ 434

Johnston Jolm ......... 275

Johnston Mercey ..........

Joles Thomas .............

Joyce Jno ..............

Jolef Jno Jun ...............

Jenings Henry ..........

Jolef Jno Sen ............

Kaine Richard ............

Langley $\mid \mathrm{m} m$.................

Langley Thomas ..........

Loveney James ...........

Luelling Edward ..........

Luelling Richard ..........

Lovell Viddow ............

Low Henry .............

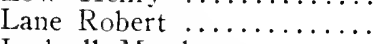

Ludgall Matthew .........

Levima John ...............

Lenton $\mathrm{V}$ 'm .................

Mercer Thomas ............

Maning Thomas ...........

Maning Nicholas ..........

Mones Joseph .............

Matthias Matthew .........

Miller IVm ..............

Miller Jno ...................

Miller Viddow ..............

Murden Viddow .............

Miller Thomas ..............

Maund $\mathrm{V} / \mathrm{m}$................

Maning Jno Sen .............

Miller Joseph ..............

Mocey Dennis Sen \& Jun...

Mohan James .............

Murfrey Alexander ........

Maning Ino Jun .............

Moseley Widdow ............

Miller Widdow Sen .......

Mason Thomas ............

Masom Lemnell .............

Mason Thomas ............

Mason George ..............

Mockey Adam .............

Newton George ............

Nicholson Jno
275

200

200

300

100

840

50

1487

878

100

315

200

7.40

I9 I

460

250

$5 \mathrm{IO}$

I 50

600

97

260

73

I 00

I 090

200

IOO

2000

1050

200

300

$88_{2}$

I 60

100

800

I00

300

200

I 25

400

653

300

400

II I )

I 60
Nash Thomas .......... 50

Nicholson Henry ........ 320

Nash Richard ........... I00

Nicholson Win .......... 300

Norcote Thomas ......... 273

Outlaw Edward ......... 208

Owens $\mathrm{Wm} . . . \ldots \ldots \ldots .6 .650$

Odyam $\mathrm{Wm} \ldots \ldots \ldots \ldots .200$

Pearce $1 \mathrm{Mm} . . . \ldots \ldots \ldots \ldots$ I00

Peters Widdow ........... 698

Portlock .............. 360

Porter Samuell .......... I00

Prescot Moses .......... I 200

Philpot Richard .......... 200

Powell Richard .......... Ioo

Powell Lemuell ......... 246

Powell IVm ........... 624

Perkins IVm ........... 50

Patison Robert ........ 350

Roberts Jos ............ I00

Robert Samuell ......... 800

Rose Robert ........... 385

Rose Jno ............. 60

Randall Giles ........... I50

Richardson Thomas ..... 379

Spring Robert .......... ${ }_{98}$

Spivey Matt .......... 600

Smith John ............ I27

Scoll Thomas ............ 400

Smith Richard ............ 600

Smith John ............ 200

Silvester Richard ......... I 280

John Smith Sen ........... I I 200

Sickes Walter Sen ....... 550

Sickes John ........... 200

Sugg George ........... to

Sugg $\mathrm{Wm} \ldots \ldots \ldots \ldots \ldots .200$

Sayer Francis ........... 600

Smith Humphrey ........ I0

Standbro Jno ........... to

Standley Richard ......... 200

Sharples Henry .......... 100

Sugg Joseph ............ 300

Symons Thomas ...........

Symon James .......... 200

Sparrow Wm .......... 350

Tuker Vm ...............

Thornton Francis ........ 200

Thurston Matthew ....... 100

Theohald James ........... I to

Thellahall Widdow .........

Tuker Richard ............ 100

Tuker Thomas ......... 280 
Taylor Jno ............

Taylor Richard .........

Tully Jno .............

Tarte Elezar Sen .........

Taylor Andrew .........

Tuker Jno .............

Tart Alice ..............

Tarte Elezar Jun ........

Taylor $1 \mathrm{~V} m$............

Trigoney Henry .........

Velle Moriss ............

Nalice Thomas .........

Weston Edward ..........

Willoughby Thomas Coll ..

Weshart John ..........

Woodly Robert ...........

Williams John $\ldots \ldots \ldots \ldots$

Vilder Mich ............

Watkins Thomas ........

Williamson Jno .........

Whedon Jno Jun .........

Willoughby Thomas Capt ..

Whedon $\mathrm{Wm} \ldots \ldots \ldots \ldots$

West John ............

Watson Robert .........

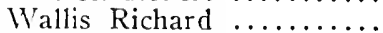

Wallis Jno ..........

Wallis $\mathrm{Wm}_{\mathrm{m}} \ldots \ldots \ldots \ldots \ldots \ldots$

Whithurst Richard .......

Whithurst $\mathrm{V} \mathrm{W} \ldots \ldots \ldots \ldots$

Wilkins Wm ...........

Williams John ..........

Whedbey George .........

Worden James ............

Wilson James Jun .........

Wilson Lemucll ..........

Wilson James Coll ........

Woodward Henry ....... 280

I90

750

I00

660

200

500

I35

450
Whedon Jno Jun .......

White Patrick ..........

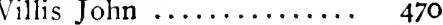

Weldey Dorothy ........ 25

Ward Jno ............ 320

Wakfield Thomas ....... 40

Vilden Nath ........... I00

Wooding Thomas ....... I70

Wood Edward .......... 100

Watford Joseph ......... 97

Wate John ........... 400

Viright $\mathrm{Wm} \ldots \ldots \ldots \ldots \ldots . \ldots 574$

Wright James .......... 216

Wadborn Mich ......... 500

Williams Jane ......... 400

Wcbb Mary .......... I00

Worminton John ........ 200

Wilden Francis ......... I I

Widdick Henry ........ 343

80

250

I 50

150

200

200

200

400

200

300

2800

Princess Anne County Rent Roll 1704

John Carraway ......... $\quad 180$

Thomas More ........... 100

Henry Chapman ......... 250

George Poole ........... 1085

James Whithurst ........ 600

Thomas Morris .......... 63

Thomas Joy ........... 600

Thomas Scott .......... I00

George Smith .......... 250

Thomas Hife .......... 200

Richard Smith .......... 200

Thomas Hattersley ....... 90
Thomas Jolley ..........

Mich Ventres .............

Capt Blomer Bray .........

James Mecoy ..............

Francis Bond ...............

Edward Wood ..............

Jno Morrah ...............

Alexander Morrah ........

Ruth Woodhouse ...........

Horatia Woodhouse ......

Joseph White ............

Jon Basnett ................
150

450

270

200

264

50

200

200

450

525

330

250 
Owen Wilbe

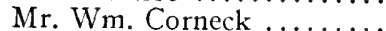

Jno Oakham ...........

David Scott .............

Jno Keeling . . . . . . . . .

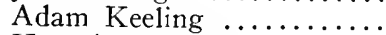

Humphrey Smith .........

Jno Halise ............

Capt Wm Crawford ......

Richard IVilliamson ......

Edward Tranter ..........

Jno. Sherland ..........

Robert Rany .............

Edward Old ...........

Coll Lemuell Mason ........

Mr. Francis Emperor .......

James Kemp ............

Bartho: Williamson $\ldots \ldots \ldots$

Symon Hancock Jun ......

George Batten ...........

Matth : Brinson ..........

Mr. Edward Mosseley Sen...

Wm Martin

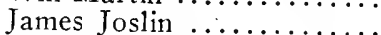

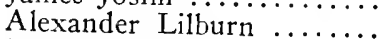

James William ..........

Mr. Henry Spratt .........

Symon Hancock Sen ......

Thomas Walk ..........

Jno Kemp .............

Randolph Lovett ..........

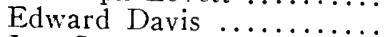

Jno Sammons $\ldots \ldots \ldots \ldots \ldots$

Elizabeth Edwards .......

Mr. Benj. Burroughs ......

Jno Muncreef ..........

Matt: Pallett $\ldots \ldots \ldots \ldots \ldots$

Mrs. Thurston ..........

Lancaster Lovett .........

Robert Cartwright $\ldots \ldots \ldots$

Jno. Cartwright ........

Nath: Macklakan ..........

Adam Thorowgood .........

Henry Walstone .........

Edward Land

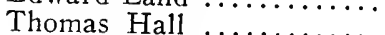

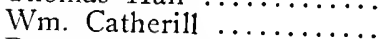

Doctor Browne $\ldots \ldots \ldots \ldots \ldots$

John Richardson ..........

Robert Richmond .........

Thomas Benson .........

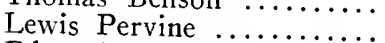

Edward Attwood
100

1974

390

600

2000

500

50

130

2650

$45^{\circ}$

I 80

soo

70

450

650

400

$68 \mathrm{I}$

400

200

I 50

250

1000

200

100

500

IOO

1736

300

298

340

IOO

200

150

50

800

140

600

290

I 850

260

100

100

700

800

400

400

I 50

600

IOOO

I000

225

800

400
Wm. Moore ........... 4 4I4

Mr. Henry Woodhouse .... 3000

Tully Emperor .......... 300

Jno. Godfrey ......... I

Wm Dyer ........... 700

Edward Cooper ........ 200

Wm Ship ............ 300

Jno Buck ............ 250

Peter Mallbourn ........ 280

Benjamin Roberts ....... IO

Capt Jno Gibbs ........ 3100

Sarah Sanford ......... I 200

Henry Harrison ........ 300

James Lemon ........... I500

Wm Wallsworth ........ IO IO

Wm Capps ..........................

Jacob Taylor ........... 80

Stephon Pace .......... 50

Adam Hayes ........... I 360

Wm Chichester ........ 400

Robert Dearemore ....... 5 I4

Capt. Francis Morse ..... 1300

Patrick Anguish ........ 150

Thomas Brock .......... 400

Wn Brock ............ Ioo

Jno Sullivant ........... 200

Francis Sheene ........ 300

Ino Acksted ........... 400

Charles Hendley ........ Ioo

Duke Hill ............ 7o

Job Brooks .......... I50

Jno Brooks ............ I0

Thomas Turton ......... IIO

Peter Crosby .......... 250

Jno Pisburn .......... 3 I 4

James Sherwood ......... 200

Edward Cannon ......... 550

Richisd Capp; ..........

Johil Doley ............ 640

Matthew Mathias ......... 80

Mr. James Peters ........ 889

Ino Owens ............ 190

Josvas Morris ...........

Thomas Mason ......... 140

Wm. Wishart .........

Jno Russell ............ 300

Stephen Sall $\ldots \ldots \ldots \ldots \ldots \ldots . . \ldots 250$

Timothy Dentis ........ 100

George Walker ........... 425

Wm. Ashby ...........

Charles Griffin ......... 2 I6

Symon Franklin ........

Alice Thrower ......... I 125 
James Wishart .......... 225

Richard Drausht....... 500

Bietor II m. Hunter ......

Mr. Jon Sanders ..........

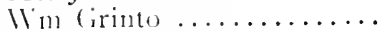

Henry Fithgerreld ........

Coll. H. Lawson .........

Capt. John Thorowgood ...

Rohert Thorowgood ......

Henry Southern ............

John Wharton ............

Joseph Doller ............

Jno Briggs ..............

Francis Jones .............

Thomas Larrey ..........

Thonas Walker ...........

Steph Swaine ............

Edward Mulsin ...........

(ieorge Bullock ...........

Ino Leggett ............

Mark Tully .............

$11 \mathrm{~m}$. Walstone ...........

Mark Powell .............

Elizabeth Nicholls .........

Hugh Hoskins ...........

Wm. Burrough ...........

Vm. Narren .............

Capt. Hutgh Campble ......

George Vorrinton ........

James Tully .............

IVm. Lovett $\ldots \ldots \ldots \ldots \ldots$

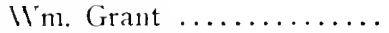

Thomas More ..........

Richard Whithurst .......

Capt. Thomas Cocke ......

John Conins .............

Thomas Griffin ..........

Thomas Spratt ...........

Jno Russell .............

James Heath ............

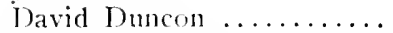

Danicll Lane .............

George Fowler ...........

Jiro Booth ...............
Giles Collier ............ 500

Jacol, Johnson .......... I700

Nexander Willis ......... $\mathbf{1 5 0}$

Richard Bonny ......... 2000

Mr. James l)oage ........ 784

Intlo: barnes ......... 200

Ino. Macklalin ......... 120

Thomas Etherington ..... 108

Jno James ............ 328

IIm. Woodhouse ....... 300

John Mayho ........... 160

Joseph Perry ............ 35

Thomas Perry ......... 650

Mr. Argoll Thorowgood ... 1000

Capt. IVm. Moseley ...... 600

Jno Moseley ........... 325

Wu. Smith ............ I80

IIm. Symmons ......... 400

Adam Forguson ......... 120

banj. Commins ........ 200

Jno Elkes ............ 500

Patrick White ......... I250

Richard Jones .......... 200

Evan Jones ............ 600

Mich. Jones ............ 200

Richard Wicker ......... 300

Henry Snaile ............ 250

Mr. Samiel Bush ......... 550

Mr. Tully Robinson ...... 500

Jno Briberry ........... 50

Wm. Moseley .......... 50

Capt. Christ. Merchant ... 400

Richard $\operatorname{Cox} \ldots \ldots \ldots \ldots \ldots .65$

Matt. Godfrey ........... I50

Thomas Tully .......... 600

Hector Denby ........... 600

Thomas Keeling ......... 700

IIm. More ............ 100

Thomas Cason .......... 550

Sarah Jackson .......... 600

Jacob More ............ 200

Ienry Spratt

A True and Perfect Rent Roll of the Lands In Elizabeth City County for the Year 1704

Coll. Wm. Wilson ....... 1024

Mr. Wm. Smelt ......... I50

Mr. Pasquo Curle ....... 300

Mr. Nicho. Curle ..........
Coll. Dudley Diggs .......

Samuell Pearce ..........

Mary Jenings ............

Mark Powell ..............
216

IDO

250

184 
Wm. Davis

42

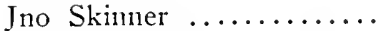

Thomas Baines ..........

Wm. Latham ............

Thomas Tucker ..........

Matthew Smell ............

Charles Cooley ............

Jno Chandler .............

IVm. Umpleet .............

Charles Tucker ...........

Thomas Allin .............

Wm. Williams per the

School ...............

Wm Williams per himself..

Mrs. Bridgett Jenkins .....

Christopher Davis ........

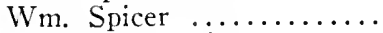

Thomas Hawkins .........

Jno Bowles ...............

Ino Theodam ............

Bartho. Wetherby .........

Jos: White ...............

Capt. Henry Royall .......

Robert Bright Sen. ........

Thomas Naylor ...........

George Cooper Sen .........

Thomas Needham .........

Cha: Cooper .............

IVm. Dumn .............

Charles Jenings ..........

Samuell Darill ..........

Paltey Davill ............

Francis Rogers ...........

Thomas Babb per Selden ..

Richard Horsley ..........

Sarah Nagleer ............

Henry Dunn ..............

Peter Pearce .............

Moses Davis .............

Mich: Breltuen ............

Henry Robinson ............

Christo. Copeland ..........

Thomas Faulkner ..........

Mr. James Wallace ....... I300

Mr. Berthram Servant .... 4 is

Robert Taylor .......... 50

Joseph Harris .......... 50

Wm. Robinson ......... 50

Wm. Boswell ........... 220

Wm. Winter .......... 70

John Lowry per Selden ... I IO

Edward Roe ........... Ion

Henry James ........... 100
Richard Roatton ........ 50

Thomas Poole ........... I 200

John Wheat Land ........ 66

George Bell ............. 80

II iddow Ballis ......... 350

George Walker ......... 325

Mr. Robert Beverley ...... 777

Jno House ............ $\quad$ I57

Tno Bushell Jun ......... 150

Roger Masinlored ........ 50

Joln Shepherd .......... 2 I0

IVm. Minsor ............ I50

Edward Lattimore ........ I90

James Baker ............ 225

Thomas Tucker .......... 60

Jno. Cotton ............. 50

Mark Jolinson .......... 400

Major $\mathrm{Wm}$. Armistead .... 460

Coll. Antho. Armistead ... 2140

Daniell Preeday ........ 50

Matthew Watts ......... 454

Bryan Penny ............ 50

Giles Dupra ........... I50

Jno Bayley ............ 4I5

Mary Simmons ......... 200

Jno Parish ............ 50

Antho. Griggs ......... 50

Abr: Parish ...........

Mark Parish ........... 200

Benj. Smith ........... 650

Thomas Nobling per Archer 2 I2

W'm. Mallory ........... 200

IViddow Croashell ........ I0

Charles Powers ......... 400

Rolert Charwill per

Ino Young .......... 440

Samuell Fingall ......... 333

Francis Savoy .......... 50

Mr. Edward Mihills ..... 600

Jane Nichols ............ 50

John Francis ............ 25

James Priest ........... 50

Simon Hollier ............ 200

Mr. Thomas Gebb ........ 630

MIr. Richard Booker ...... 526

Mr. Wm. Lowry ........ 526

Mr. Merry or Mrs Dunn... 500

Wm. Haslyitt ........... I00

Capt. Augustine More .... 285

John More ............ 250

John Passones .......... 780

Rebeckha Morgan ........ 50

Thomas Roberts ......... 250 
Mr. John Turner ...........

Henry Lais ..............

Capt. Henry Jenkins .......
50
50
300

Mr. Francis Ballard per

Selden

460

29560

Henry Royall Sgeriff

A True \& Perfect Rent Roll of all the Lands that is held in Warwick County I704

Major Wm. Cary ..........

Mr. Nedler Plantacon ......

Rober Hubbert ...........

Wm. Harwood ...........

Richard Glanvills Orphans.

Wm. Hubbert .............

Henry Gibbs .............

Wm. Hewitt ..............

James Hill ..............

John Golden .............

Thomas Harwood ........

Jno. Harwood ............

Capt. Thomas Charles .....

Hump: Harwood .........

Matthew Wood ...........

Edward Joyner ...........

Coll. Dudley Diggs ........

Elizabeth Lucas ...........

John Hillard ..............

Edward Loftes ............

Wm. Rowles Orphans .....

Samuell Hatton ...........

Isaac Goodwin ..........

George Robinson ..........

Seymon Powell ...........

John Dawson .............

Wades Orphans ..........

Henry Dawson ............

John Bowger .............

Joseph Cooper ............

Robert Roberts ...........

George Burton ............

Capt. Mills Wells ........

Roger Daniell Orphans ....

Jno Hansell .............

Emanuell Wells ..........

Elizabeth Wells Widdow ..

Widdow Lewelling ........

Wm. Wells .............

Elias Wells ..............

Widdow Pierce ...........

Thomas Haynes ..........

John Scarsbrook ..........
300

80

IOI

625

I65

200

315

150

I 35

50

575

704

100

400

300

60

4626

800

74

60

I5O

225

225

70

250

300

IOO

200

100

200

60

330

425

196

100

325

I 55

100

615

50

155

850

850
Francis Jones .............

Matthew Jones ............

Jno. Read ...............

Mr. Brewer Land ........ I350

Mr. Henry Cary ........ 670

Langhorne Orphans ...... 602

Coll. Coles Orphans ....... I350

Peter Jones ........... I50

Samuell Crew Orphans .... I50

Samuell Symons ......... I73

Mrs. Elizabeth Whitaker.. 600

Capt. Miles Cary ........ 600

John Cannon ........... 75

John Linton ............ 75

Richard Gough .......... 60

'Coll. Miles Cary .......... 1960

Mr. Jno. Mallnote ........ 6i

Rowlands Williams ....... 170

Robert Chapell .......... I50

James Chapell ........... I00

Edward Powers ......... 200

James White ........... 40

Peter Sawers Orphans .... 95

Wm. Cotton ............ I43

James Cotton ........... 70

John Croley ............. I00

Stephen Burgess ......... I 128

Widdow Yorgen ......... 60

George Jackson .......... 193

Sarah Ranshaw .......... I25

Richard Wootton ........ 243

Samuell Hoggard ......... I 120

James Floyd ............ 100

Fr: Rice Orphans ....... 200

Mr. Math Hoggard ........ 270

$\mathrm{W}^{\prime}$ iddow Chapell $\ldots \ldots \ldots \ldots$. $32 \mathrm{I}$

Thomas Ascow .......... 50

Garrett Ridley ........... 300

Samuell Ranshaw ........ 238

Charle Stuckey ........... 86

Jos Naylor ............ 100

Jos Russell ............ 150

Charles Allen ........... 295 
Wm. Newberrey ......... 100

John Turmer ............ 100

Wm. Smith ............. I50

Elizabeth Holt ........... I50

James Browne ........... 150

Henry Royall ............ $\quad 246$

Edward Rice ........... 375

Thomas Blackistone ....... 75

Mark Noble ............ 2 I5

James Reynolds ......... 75

John Holmes ............ 200

Samuell Duberry ......... 200

Edward Powers .......... 200

Jno Hatton Orphans ..... 93

Wm. Lowland ............ 25

Thomas Morey ........... 363

Wm. Bracey ............. I50

Cope Doyley ........... 500

Nath Edwards ........... 100

Samuel Groves ............ 490

Croncher Orphans ........ 50

Henry Whitaker ........... 60

Woodman Land .......... 200
Wm Cook ............. 29

Jno Tignall .............. 392

Thomas Mountfort ........ 890

Joseph Mountfort ....... 558

James Priest ............ 50

Abr. Cawley ............. 80

Wm. Jones .............. 70

Edward Davis ........... 200

The County Land ......... 150

Denbigh per Gleab ........ 130

Mulberry Island Gleab..... 50

Thomas Hansford ....... 75

Mr. Rascows Orphans ..... 1195

Thomas Hansford never 37685 before paid ............ 75

37610

Persons out of the County

Ino Trevillian .... 248

Holman Orphans .. $200 \quad 448$

Robert Hubberd Sherriff

\section{A Rent Roll of all the Land In York County 1704}

Wm. Jackson ............ 200

Matt: Pierce .............. I00

Jno. Latin .............. 150

Robert Cobbs ............ I00

Francis Sharp ........... 100

Geo: Baskewyle ........ 350

Richard Gilford .........

Jos: Frith ............. 50

Wm. Jones ............ 70

Nath: Crawley $\ldots \ldots \ldots \ldots, \quad 384$

Thomas Crips ........... 750

Wm. Davis .............. 200

Lewis Barnoe ............... 80

Arthur Lun .............. 50

Jno. Bates ............... 669

Jno Serginton ........... 150

Wm. Taylor ............. I

Richard Page ............ I50

Wm. Jorden ............. 580

Jno. Lynes ..............

Alex: Banyman $\ldots . \ldots \ldots$. 50

Wm. Cobbs .............. 50

Mary Whaley $\ldots \ldots \ldots \ldots \ldots, 550$

Henry Tyler .............. 180

Richard Kendall .......... I 150

Wm. Hansford .......... 300

Nicholas Sebrell ......... 150
David Stoner ............ 50

Ralph Hubberd .......... 50

Wm. Harrison...$\ldots \ldots \ldots .6$. 50

Jno. Wyth .............. I00

Thomas Hill ........... 930

Thomas Vines .......... 200

Morgan Baptist .......... 100

Phil. Deadman .......... 75

Bazill Wagstaff .......... 127

Wm. Allen .............. II

Robert Read ........... $\quad 750$

Jos: Mountford ......... 307

Roger Boult ............ 100

Edward Fuller ........... 70

Thomas Jefferson ......... I00

Henry Duke ............. 25

Jno. Hansford ........... 100

Robert Peters ............ $\quad 160$

Jno. Morland ............ 100

Wm. Lee ............... 350

Richard Burt ............ 200

John Eaton ............ 170

Rob: Starke ........... 250

Robt. Harrison .......... 200

Jno. Morris ............. $\quad 125$

James Bates ............ I17

Elizabeth Jones $\ldots \ldots \ldots \ldots .94$ 
Edward Young ............

Robert Green ............

Tho: Fear ...............

Edward Thomas .........

John Loyall .............

Stephen Pond .............

Wm. Wise ..............

Cornelius Shoohorn ......

Joseph White ............

Daniell Park Esq. .........

Thomas Fear Jun ........

Orlando Jones ...........

Ambrose Cobbs ...........

Henry Dyer.$\ldots \ldots \ldots \ldots$.

Wm. Davis ..............

Wm. Buckner ............

Tho. Barber .............

Elizb. Tindall ............

Dudley Diggs.$\ldots \ldots \ldots \ldots$.

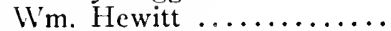

Mary Collier ..............

Charles Collier ............

Tho. Hansford ............

Geo. Browne ............

Wm. Gibbs ..............

Wm. Pekithman ...........

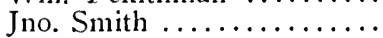

Baldwin Matthews .......

Jno Daniell ..............

Seamor Powell ...........

Jno. Lewis Esq. ...........

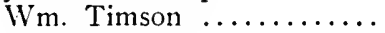

Jno. Page $\ldots \ldots \ldots \ldots \ldots \ldots$

Jos. Benjafield ............

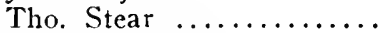

Stephen Fouace ............

Edmund Jenings Esq. ......

Elizb. Archer ................

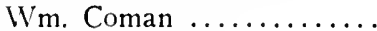

Elizb. Hansford ..........

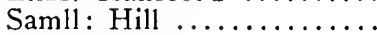

Jno. Anderson ..............

Tho Buck ................

Lewis Burwell ............
Robt. Crawley ...........

Robt. Hyde ................

Robt. Harrison .............

Jeffry Overstreet ..........

Tho. Overstreet ...........

John Myhill ................

Mary Roberts ............

Benja. Stogsdall ..........

Tho Wade
100

200

100

223

100

200

850

100

750

2750

I3O

450

163

50

100

$3021 / 2$

600

60

I $35^{\circ}$

I50

433

684

75

150

50

650

I 50

I 300

200

I 30

300

1000

490

80

60

565

850

370

50

100

25

50

250

2100

400

200

250

50

50

52

25
Jos: Walker ........... 615

Jno. Sanders .......... I00

Mongo Inglis ......... 400

Tho Holyday .......... I00

Jno. Williams .......... 100

Antho: Sebrell .......... 50

Robt. Jones ........... I00

James Cansebee ......... 200

Richd. Booker .......... 200

James Morris .......... 100

Henry Adkinson ......... 82

Robt. Jackson .......... 150

Anthoney Robinson ....... 183

Hannah Lamb .......... 50

James Calthorp ......... 900

Tho Boulmer ........... 265

Peter Pasque ............ I2

Jno. Chapman .......... 70

Jno. Pond ............ II

Sarah Tomkins ......... 250

Robt. Kirby ........... 200

Tho. Kirby ............ 270

Edward Curtis ......... 200

Jno. Forgison ........... 200

II'm. Row ............. 902

Jno. Hunt ........... 550

IVm. Taverner .......... I00

Armiger Wade ......... 424

Richard Dixon ......... 450

Edmund Jennings Esq. .... I650

Jno. Persons .......... 300

Tho. Nutting ............ 375

Peter Manson ........... 150

Richard Slaughter ........ 275

James Persons .......... 350

Tho. Roberts ............ 450

Jno. Toomer .......... 335

Daniell Taylor ........... 225

Robert Hayes ............ 220

Henry Andros .......... 274

Jino. Wells $\ldots \ldots \ldots \ldots \ldots \ldots \ldots, 750$

Robert Curtis .......... 250

Tho. Cheesman Sen. ....... I800

Jos Potter ............. 25

Hen: Heywood ........... 1300

David Holyday .......... 600

John Northern .......... 130

Jno. Doswell ......... 367

Isaac Powell ............ 100

Symon Staice ............ 200

Jino. Drewet .......... 200

Robert Topladie .......... 100

Jno. Potter ........... 93 
Lewis Vernum ......... 150

James Slaughter ......... 250

Tho: Burnham ......... 50

Jno: Doswell Jun ........ 100

Robert Shields .......... 400

Wm. Wilson ........... 50

Owen Davis ........... 247

Tho. Walker ............ I00

Richard Nixon ........... 150

Henry Clerk ............ I00

Elias Love ............. 25

Wm. Howard ........... I00

Jno. Sanderver ........... I00

Jno. Cox .............. 50

Tho. Gibbins .......... 100

Tho. Hind $\ldots \ldots \ldots \ldots \ldots \ldots$. 100

Tho Cheesman Jun ....... 600

Wm. Browne ............ 200

Jno. Rogers ............ 650

Jno. Moss ............. I 50

Jno. Lawson ........... I00

Nicho. Philips $\ldots \ldots \ldots \ldots \ldots$. 150

IVm. Sheldon ............ 750

Jno. Wayman .......... 100

Tho Edmonds ........... 150

Lawrence Smitl .......... I

James Paulmer .......... I50
Wm. Gurrow .......... 150

Peter Goodwin ........... 400

Robt. Snead ............ 50

Edward Cawley .......... 150

$\mathrm{I} \mathrm{m}$. Gorden ............. 150

Jno. Hilsman ............ 75

Jno. Wright $\ldots \ldots \ldots \ldots \ldots$ r. 100

Jno. Gibons ............ 50

Elizb. Goodwin ........... 1200

Samuell Cooper ........... 150

Jno. Fips . . . . . . . . .

Tho IVooton ............

Edward Moss ............. 759

Rebecka Watkins ......... 100

Wm. Whitaker ............ 1800

Hampton Parish .......... 200

Bruton parish Gleabe ....... 300

Robt. Iry he living in James City County \& no Tennt. on ye Land.... IOO

Added to make up the

6 II $32 \frac{1}{2}$

old Roll

Wm. Barbar S Y C

The Rent Roll of the Land in James City County 1704

\section{A}

Adkinson Tho $\ldots \ldots \ldots \ldots$...... 50

Adkinson Henry .......... 250

Armestone Joshua ....... 50

Adams Anne ............. 150

Argo James .............. 200

Abbitt Francis ........... 100

Apercon $\mathrm{Wm} . . . \ldots \ldots \ldots \ldots$ so

Allen Richard $\ldots \ldots \ldots \ldots \ldots$..... 540

I 420

\section{B}

Baker Jno............. 100

Bentley Jno $\ldots \ldots \ldots \ldots \ldots \ldots$. 125

Bess Edmund ........... 75

Burwell Lewis .......... 1350

Beckitt Tho $\ldots \ldots \ldots \ldots \ldots$. 6 . 60

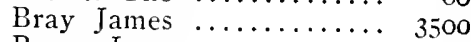

Bryon Jno. ........... 100

Bingley James .......... 100

Benham Jno. ............ 50

Brown James .......... 250
Bowers Wm. .......... 50

Broadnax $W$ m. ............ ${ }_{1683}^{50}$

Bayley $\mathrm{W}_{\mathrm{n}} \ldots \ldots \ldots \ldots \ldots \ldots$. 100

Black Geo ............... 200

Bush Jno .............. 800

Ballard Tho ............

Bray David ............... $5755^{8}$

Burton Ralph ............ 200

Blankitt Henry ...........

Brand Richard $\ldots \ldots \ldots \ldots \ldots \ldots, \quad 100$

Breeding Jno. ............ 100

Bruer Thackfield .......... 350

Blackley $W m \ldots \ldots \ldots \ldots .$.

Barratt Wm. ............ 305

Barron Tho .............

Blankes Henry ........... 650

Bagby Tho ..............

Barnes Francis $\ldots \ldots \ldots \ldots . .200$

Brackitt Tho $\ldots \ldots \ldots \ldots \ldots$. 150

Browne Wm. ...........

Buxton Samueli .......... 30 r...

Bimms Christo. .......... 300

Ballard Wm. ........... 300 
Frayser Jno

Benge Robert $\ldots \ldots \ldots \ldots \ldots .6 .6 .60$

I9I23

C

Center Jno ............. I00

Clerk Wm. ............. I I

Charles Phill ........... 200

Capell Tho. ............ 200

Cearley Wm. ............ 450

Clerk Robert ........... 300

Clerk Sarah ........... 200

Cole Richard ............. 80

Cooper Tho ............. 60

Cook Richard ........... 75

Cosby Charles .......... 250

Crawley Robert .......... 460

Cryer George ............ IOO

Cobbs Ambrose ......... 350

Cock Jonathan .......... 250

Cowles Thomas ......... 675

4850

D

Dormar Jno. ........... I00

Drummond $\mathrm{W} n 1 \ldots \ldots \ldots .$. I 50

Deane Jno ............. I50

Duckitt Abraham ........ 290

Danzee Jno Jacob Coignan 4III

Deane Tho .............. 80

Deane $\mathrm{Wm}$............. I00

Drummond Jno ......... 700

Deane Tho ............ 150

Duke Tho ............... 750

Davey Francis ......... 778

Doby Jno. ........... 300

Duke Henry Jun ........ 50

Duke Henry Esq. ........ 2986

II 605

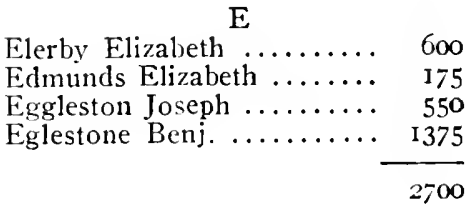

$\mathrm{F}$

Feareclotl tho $\ldots \ldots \ldots \ldots, 277$

Farthing Wm. .......... 50

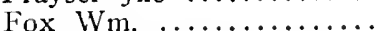

Fouace Stephen ...............

Fish Jno. ...............

Freeman George ..........

Furrbush Wm. ............

Flanders Francis ........ 350

I 824

G

Goodrich Benj. .......... I650

Gwin Jno. ............ I00

Garey Tho............... 60

Guilsby Tho. .......... 300

Graves Joseph .......... 250

Goss Charles ............ I7I

Goodall Jno. ........... 400

Geddes $\ldots \ldots \ldots \ldots \ldots \ldots .476$

Gill Jno............... IOO

Green Tho. ............ 50

Gregory Nicho. .......... 50

Green Wm............ I00

Ginnings Phill. ........ 400

Gibson Gibey ........... I50

Goodman John .......... 275

Goodwin Robert ........ 150

Grice Aristotle ......... 700

Greene Tho $\ldots \ldots \ldots \ldots \ldots$. 500

5882

\section{$\mathrm{H}$}

Hudson $\mathrm{Wm}$............ 50

Herd Leph. ..............

Hadley Dyonitia ......... I00

Hall Jno. ............. 50

Harvey George ........... 1425

Howard Jno............ 25

Hughes Geo. ........... 250

Harfield Mich .......... 50

Hudson George ........... I00

Hudson Leonard ......... I70

Hood Jno.............. 250

Harris Wm. .......... 140

Hamner Nicho. .......... 500

Henley Leonard .......... 360

Hooker Edward .......... 1067

Higgins Jno. ........... 75

Henley Jno............ 100

Holiday Tho. .......... 250

Hitchcock John .......... I00

50 Holeman James ......... 150 
Hubert Matt ........... I834

Handcock Robt. ........ 300

Haley James ............ 3 Io

Hook Mick .............. 260

Hill Tho. .............. 310

Hatfield Richard ......... IOO

Hilliard Jerimiah $\ldots \ldots \ldots \ldots$..... 225

Hilliard John ............ 200

Hopkins John .......... I 20

Hunt Wm. ............ I300

Hix John ............. 115

Harrison $\mathrm{Wm} . . . \ldots \ldots \ldots \ldots$ I 50

Hawkins John .......... 200

Hix Joseph ............ 100

Harrison Benj. Jun ........ 100

10936

Inch Jno. ............. 30

Jone Fred $\ldots \ldots \ldots \ldots \ldots \ldots$ 300

Inglis Mingo ........... I300

Jenings Edmund Esq. ..... 200

Jaquelin Edward ......... 400

Jeffrys Tho ............. 60

Jackson Elizabeth ........ 200

Jackson Richard ......... I50

Jeffrys Matt. ........... IOO

Johnson Antho ........... I00

Jones Wm. ............ 50

Johnson Jno ........... 260

Jones $\mathrm{Wm} . . . \ldots \ldots \ldots \ldots$ I5O

Jordan John .......... 1000

4265

\section{$\mathrm{K}$}

Knowstarp ........... I 150

\section{$\mathrm{L}$}

Lawrence Richard ........ 250

Ludwell Phil Esq ........ 6626

Lattoon John ............ 75

Lund Thomas $\ldots \ldots \ldots \ldots \ldots$ r.

Lillingtone Benj. ......... I00

Lidie Robt. ............ 500

Loftin Comeles .......... 200

Light foot Phil $\ldots \ldots \ldots \ldots$ I6 160

Lightfoot Jno. Esq ....... 250

Love Jno. ............... 100

Loftin Comeles Jun ...... 200

Liney $\mathrm{Wm}$.

\section{$\mathrm{M}$}

Mookins Roger ......... I60

Macklin Wm ........... 300

Marston Wm ............ 150

Morris Edward Jun ....... I00

Manningaren $. . \ldots \ldots \ldots \ldots . \quad 150$

Marston Tho ............ I000

Martin Richard ............ I50

Maples Tho ............ 300

Muttlow Jno ............ I

Morris James ........... 800

Moris David ............ $\quad 170$

Myers Wm Jun ......... I00

Mountfort Tho ......... 600

Morris John ........... 195

Marble Geo ............ I 35

Mallard Poynes .......... 100

Merryman James ........ 300

Morecock Tho .......... 700

Meekings Tho .......... 175

Marraw Dennis ......... 30

Major John ............ I00

5885

\section{$\mathrm{N}$}

Norrell Hugh ........ 328

Nicholson Jno ............ I44

Nicholls Henry .......... 100

Nailer Wm ............. 300

O'Mooney Mary .......... 126

998

$\mathrm{P}$

Prince George .......... 50

'Page John .............. I700

Page Mary ............ 900

Pigot Benj. ............ 90

Pall Wm .............. 450

Parker Tho ............. I650

Peper Stephen .......... I

Phillips Jno ........... 300

Pattison Alex ........... 100

Perkins Charles ......... 320

Philips Edward .......... I00

Philips Wm ........... 300

Pearman Wm ........... 270

Pearman Jno ........... 200

Pendexter Tho .......... 550

Parish Tho ............. I00

Pattisson Tho ......... 200 


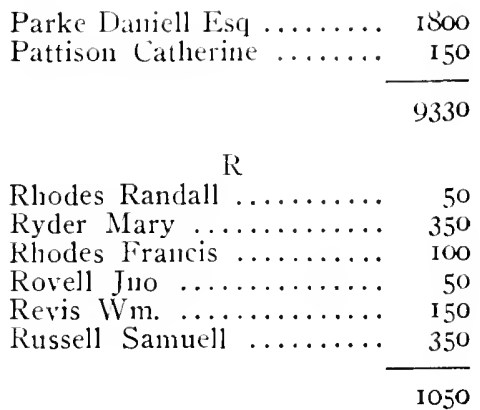

S

Stafford Mary ......... 210

Sanders Jno. ........... 50

Sewell Jno............ 75

Sprattley Jno. ......... 350

Smith Christo. ........... 450

Short Jno. ............. 90

Smallpage Rolst. ......... I90

Santo Robt. ............. IOO

Smith Jno. ............ II 4

Slade Wm. .............. 80

Soane Henry .......... 750

Sykes Barnard .......... IOI2

Selvey Jacob ........... 50

Sharp Jno.............. 800

Shaley Jno ............ 150

Simes WVm. ........... 650

Sorrell Mary ........... 500

Sherman Elizb. ......... 500

6121

Tinsley Edward ${ }^{\mathrm{T}} \ldots \ldots \ldots$ I00

Tinsley Richard .......... Io0

Tomson James .......... I0

Thackson John ......... 289

Tyery Wm. ............. ${ }_{1590}$

Thurston John ......... 500

Thomas IVm. .......... I50

Tyler Henry ........... 730

Tullett John ............. 625

Thomas Hanal .......... I00

Thomson Henry ........ 150

Twine Tho.............. 100

Thomas Ino. .......... 250
Vaughn Henry ........ $\mathbf{1 9 0 0}$

Udall Mattlew ......... 50

Verney Wm............ 50

Vaiding Isaac $\ldots \ldots \ldots \ldots$.... 300

2300

IV

Veathers Tho.......... I30

Wood Richard ........... I 30

Whitaker Wm.......... 320

Ward Tho. ............. I00

Weldon Sarah .......... I00

Whaley Mary ........... 200

Winter Timo. ............ 250

Wilkins Samll. .......... I70

IVright Samll. ......... I00

Winter $W^{\prime} m . . . \ldots \ldots \ldots \ldots$ I 100

Williams Matt. ........... 75

Walker Alex. .......... 500

Williamson John ........ I 120

Walker David ........... I 50

Walker Alex. Jun. ........ 2025

Warberton Tho. ......... 190

IVeldey Geo. ........... 317

Wragg Tho. ........... 500

Wooton Jno. ............. ${ }_{150}$

Willson Jno............. I40

Wilkins Tho. .......... 600

Wood Edward ........... 300

Wood Tho. ............. 200

VIalker David ............ I00

Ward Robt. ........... 800

Wright Mary ............ 175

Woodward Lanslett ...... 650

Woodward John ......... 650

Woodward Geo. ......... 350

Woodward Samll. ........ 350

Ward Henry ............ I50

IVard Edward ........... 150

10662

Y

Young Rol,t. ........... 350

Young Thomas ......... 350

700

$4784 \quad$ II 4780 
Benj. Shottwater of York

County ............. 300

Tho. Sorrell .......... 300

Mary Nosham at the

Blackwater

$\frac{168}{768}$

Henry Soane Junr. Sher.

The Totall of the Acres in James City County

Discovered of this for which I 14780 the Shreiff is to be allowed the Qt. Rts, according to his Ex.cy odrs in Cuuncil

6000

$\overline{108780}$

108780 acres at 24 tob per 100 is $\ldots \ldots \ldots \ldots \ldots 2610 \%$ tob

Whereof pd in Aronoco at 6 per $\mathrm{Ct} \ldots \ldots \ldots \ldots+4000$

I 2.0 .0 In Sweet Scented at 3s " $4 \mathrm{~d}$
per Ct. $\quad \ldots \ldots \ldots \ldots \ldots 22107$

92.2 .3

104.2.3

\section{New Kent County Rent Roll}

A Rent Roll of the Lands lield of her Majte in the Parish of St. Peters and St. Paulls. Anno I704.

\begin{tabular}{|c|c|c|c|}
\hline Alford John ............. & 240 & Bradbury Geo & 100 \\
\hline Allen Richard $\ldots \ldots \ldots \ldots \ldots$ & 550 & Brothers Jno. & 200 \\
\hline Alex Abraham ........... & 100 & Bayley Jno ... & 80 \\
\hline Allen Robt. $\ldots \ldots \ldots \ldots \ldots$ & 100 & Beck Wm Mr. .......... & 200 \\
\hline Austin $\ldots \ldots \ldots \ldots \ldots \ldots \ldots$ & 245 & Butts Alice $\ldots \ldots \ldots \ldots \ldots$ & 150 \\
\hline Austin James $\ldots \ldots \ldots \ldots \ldots$ & 700 & Burnell Mary Mrs. ....... & 2750 \\
\hline Amos Fran $\ldots \ldots \ldots \ldots \ldots$ & 100 & 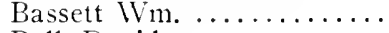 & 550 \\
\hline Ashcroft Tho $\ldots \ldots \ldots \ldots$ & 180 & Ball David .. & 200 \\
\hline Aldridge Jno $\ldots \ldots \ldots \ldots \ldots$ & 250 & Baughan Jno Junr ........ & 300 \\
\hline Atkinson Jno $\ldots \ldots \ldots \ldots \ldots$ & 300 & Bassett Tho $\ldots \ldots \ldots \ldots \ldots$ & 350 \\
\hline Anthony Mark ........... & I90 & Blackburn Rowland ....... & 700 \\
\hline Anderson Jno $\ldots \ldots \ldots \ldots$ & 100 & Baker Christo $\ldots \ldots \ldots \ldots$. & 100 \\
\hline Anderson Robt $\ldots \ldots \ldots \ldots \ldots$ & 900 & Beer Peter $\ldots \ldots \ldots \ldots \ldots$. & 100 \\
\hline Arise Margt $\ldots \ldots \ldots \ldots \ldots$ & 200 & Brooks Richd & 85 \\
\hline Austin Rich $\ldots \ldots \ldots \ldots \ldots$ & 50 & Burnell Edwd ............ & 200 \\
\hline Anderson Robt. ........... & 700 & Brown Jno $\ldots \ldots \ldots \ldots \ldots$ & 100 \\
\hline Anderson David .......... & 300 & Bullock Richd $\ldots \ldots \ldots \ldots$ & 450 \\
\hline Anderson Rich $\ldots \ldots \ldots \ldots$ & 200 & Blackwell James Junr ...... & 200 \\
\hline Allen Reynold $\ldots \ldots \ldots \ldots$ & 205 & Brooks Roht $\ldots \ldots \ldots \ldots \ldots$ & 45 \\
\hline Allvis George $\ldots \ldots \ldots \ldots$. & 325 & Bulkley Benj . . . . . . . . & 200 \\
\hline Aron Josiah $\ldots \ldots \ldots \ldots \ldots$ & 200 & Blackwell ............... & 950 \\
\hline Amos Nocho & 50 & Baughan Jno & 100 \\
\hline Allen Daniell $\ldots \ldots \ldots \ldots \ldots$ & 250 & Baughan Josepli ..... & 100 \\
\hline Allen Samll $\ldots \ldots \ldots \ldots \ldots$ & 150 & Bostock J110 $\ldots \ldots \ldots \ldots \ldots$ & 100 \\
\hline Anderson John ........... & 100 & 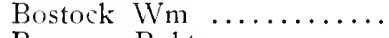 & 80 \\
\hline \multirow[t]{4}{*}{ Ashley Charles ........... } & 100 & Bumpis Robt. $\ldots \ldots \ldots \ldots$ & 100 \\
\hline & & Burwell Lewis ......... & 200 \\
\hline & 6785 & Bryan Charles..$\ldots \ldots \ldots$ & 100 \\
\hline & & Bullock Edwd...$\ldots \ldots$. & 450 \\
\hline Boll & & Blalock J110 & 492 \\
\hline 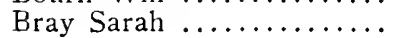 & 790 & Bearne Henry & 50 \\
\hline
\end{tabular}




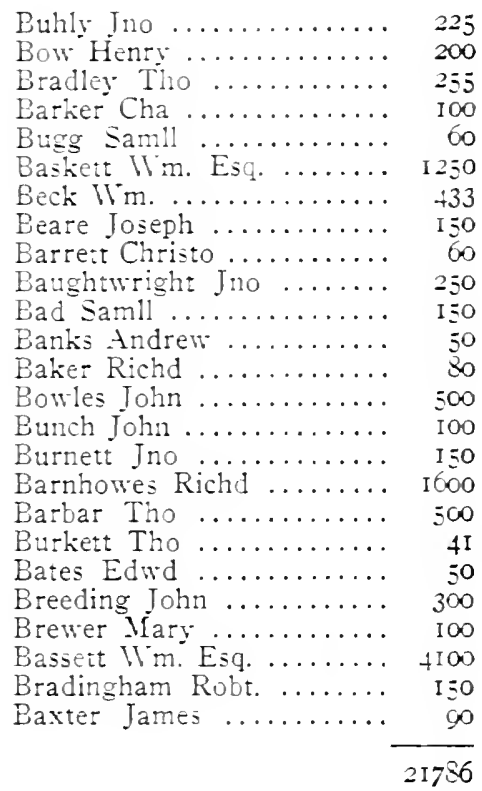

Cotrell Richd ..............

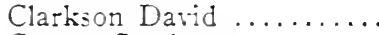

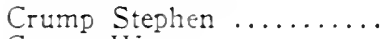

Crump Vim..............

Clopton Wm. ..............

Chandler Robt. ............

Crump Richd. ...........

Cambo Richd. ............

Crawiord David Jun .....

Crawford David Mr. ......

Chambers Edwd ..........

Clerk Edwd ................

Collett Tho ..............

Clerk Chris:o ............

Cocker $11 \mathrm{~m} . . . \ldots \ldots \ldots \ldots$.

Case Hugh ..............

Carley Richd ..............

Chiles Henry ............

Cook Abraham ..........

Crump Elizb ..............

Colum Richd ............

Crump Tames .............

Crump Robt .............

Clough Capt. .............
Chandler IVm. ...........

Chandler Francis ..........

300

Cordey Tho.

Cordey Tho.............. I50

Currell Andrew ......... 30

Croome Joell .......... 600

Crutchfield Peter ......... 400

Chesley $11 \mathrm{~m} . \ldots \ldots \ldots \ldots$...... 500

Crutchifeld Junr ......... 400

Carlton Wm. ............. Ito

Chambers George ....... I00

Cox $11 \mathrm{~m} . . . \ldots \ldots \ldots \ldots .350$

9251

$\mathrm{D}$

Dolerd $11 \mathrm{~m} \ldots \ldots \ldots \ldots \ldots$ 50

Dennett John .......... 350

Durham James ......... I00

Dumas Jerimiah ......... 250

Deprest Robt .......... 350

Dodd John ............. 300

Dabony James ......... 320

Davis Elizar ............. 375

Duke Henry Esq. ........ 325

Dibdall Ino ........... 800

Darnell Rachell ........... I00

Duke Henry Esq. ........ I I

Daris John ............ 80

Darenport Mest .......... I25

Daniell John ........... I50

3845

E

Eperson John .......... 120

Elmore Tho ............ 300

Elmore Tho Junr ......... 100

Ellicon Garratt Robt ..... $\quad 520$

England $\mathrm{Wm} . . \ldots \ldots \ldots \ldots .490$

Elderkin John ........... 300

Elmore Peter ........... I0

English Mungo ......... 500

Ellis $1 \mathrm{~m} . . . \ldots \ldots \ldots \ldots$. I0O

2530

F

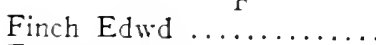

300

Foster Joseph ........... 800

Forgeson $\mathrm{Wm}$............ 507

Fleming Charles ......... 920

Francis Tho ............ I50

Freeman $\mathrm{Wm} . \ldots \ldots \ldots \ldots \ldots .20$ 
Fenton IIIddo

Feare Edmd ..............

Fisher $1 \mathrm{~lm}$.

\section{G}

Goodger Jno .............

Green Edwd ..............

Gibson Tho...........

Garrat James ............

Gonton Jno .............

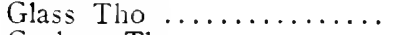

Graham Tho $\ldots . . . \ldots . .$.

Gleam Jno ..............

Giles Jno $\ldots . . . \ldots \ldots \ldots$.

Gentry Nicho .............

Garland Edwd ..............

Glass Anne ...............

Granchaw Tho ...........

Greenfield Fran. ...........

Gillmett Jno ..............

Gawsen Phillip ............

Gillmett Richd ............

Glassbrook Robt ..........

Gadberry Tho..........

Gill Nicho ..............

Gosling $\mathrm{Wm}$...............

Goodring Alexander .......

Gills John ................

Grindge Richd $\ldots \ldots \ldots \ldots \ldots, \quad 225$

$74+2$

$\mathrm{H}$

Herlock John ........... $\quad 320$

Hilton Tro .............. 300

Hughs Ino .............. iso

Huberd Jno ............ $S_{27}$

Howle Jno .............. 150

Howle Jino Junr ........... 100

Hughs Robt ............. 066

Harris Edmd ............. 100

Harris Tho .............. 100

Hawes Haugton ............ $\quad 850$

Harris John .............. It

Hill Jno ............... 250

Hester Fra ............. 300

Horsley Rowland ......... $\quad 250$

Horman Robt ............. 300

Hughes Rees ............ $\quad$ too

Hill Samll ............... 300

Holled Samll ...............

Harreliston Paul ......... 360

Hatfield Wm ........... 3 I8

Harris $\lim _{\mathrm{m}} \ldots \ldots \ldots \ldots \ldots$. 125

Harris Benj ............ I00

Horkeey John .......... 800

Hairy John ........... 280

Haiselwood Tno ........ 200

Haiselwood Tho ......... 150

Hockiday $W$ m .......... 300

Holderoft Henry ........ 95

Hogg Mary ............ I $\quad 1 \div 0$

Harmon $11 \mathrm{~m}$........... 350

Hogg T110. Junr ......... 260

Harris $1 \mathrm{~m}$............. 100

Hopkins $\mathrm{Wm}$........... 200

Howes Job ............ 300

Hight John ............ I 100

Hankins Charles ......... $3+0$

Harris $1 \mathrm{~m}$.............. 150

Harris Robt ...........

Handey $15 \mathrm{~m}$........... I50

Hogg Wm ............. 200

Haselwood Richd ......... 100

Har:ow Tho ........... 230

Hutton Geo ............. ${ }_{150}$

I I 312

\section{$\mathrm{J}$}

Tackson Tho $\ldots . . . \ldots \ldots \ldots, \quad 500$

Izard Fran ............. 1233

Jarratt Robt ........... I600

Johnson Mich .......... to

Jones John ............. 100

Johnson $1 \mathrm{~m}$........... 205

Tones Jane ............ $=00$

Johnson John .......... 100

Johnson Edwd ............. $\quad 1=0$

Jennings Robt ............ I00

Tones Fredirick ......... 500

Johes John ............. 100

Jeeres Tho .............. 100

Jones Francis ........... 200

Tones John ..............

Jones Eran .............. 500

5838

$\mathrm{K}$

King Elizb ............ 300

Kembro Ino ............. $\quad \$ \neq 0$

Kembro Ino In111 ........ $\quad$ I $\equiv 0$

Keeling Geo ............ I500

$2+90$ 
$\mathrm{L}$

Light foot John Esq. ...... 3600

Littlepage Richd ......... 2160

Losplah Peter ............ IO0

Lestrange Tho .......... 200

Liddall Geo ............ 100

Lawson Nicho .......... 200

Levermore Phill ......... I000

Lewis John Esq ......... 2600

Lawson John .......... 50

Lewis John ........... 375

Lovell Geo ............ 920

Lovell Charles .......... 250

Leak Wm ............. 280

Logwod Tho ............ I00

Lacey $\mathrm{Wm}$............ 500

Lacey Tho ............. I00

Lacey Emanuell .......... I80

Luke Jno .............. I50

Lochester Robt ......... 80

Lewis Tho ............. 115

Lee Edwd ............. I20

Lochester Edwd ........ 80

Law James ............. I00

Laton Reubin ........... I00

Linsey Joseph .......... II 50

Linsey $\mathrm{W}_{\mathrm{m}} \ldots \ldots \ldots \ldots \ldots$.

Lane Tho ............ I00

14760

$\mathrm{M}$

Millington Wm Junr ......

Mitchell Stephen Junr .....

Millington $\mathrm{Wm}$............

Moss Samll .............

Mitchell Tho ...............

Meanley $W m$.............

Minis Tho $\ldots \ldots \ldots \ldots \ldots . . .6$.

Mitchell Stephe11 .........

Moor Pelham ...............

Martin Tho ..............

Martin Martin ..............

Morris Robt ................

Moss Tho ..................

Morgan Edwd ............

Moon Stephen ...............

Major Wm ..................

Murroho Jno ...............

Moor Jno ................

Masey Tho ...............

Martin John ...............

Masey Peter ..................

450

75

200

200

300

I00

200

200

I 25

100

I5O

245

430

50

70

456

I0O

250

300

400

100
Madox John ........... 300

Martin Wm ........... 230

Martin James ........... I00

Moss James ........... 720

Moon Tho ............. 65

Mcking Alexander ....... I

Mckoy Jno ........... 300

Merridith Geo .......... 400

Melton Richd ........... 290

Morreigh John ......... I Io

Merfield John .......... 210

Mills Nicho ........... 300

Mask Jno ............. 4II

Medlock John .......... 350

Moor Edwd ............ 65

McKgene Wm ........... $13^{1 / 2}$

Merriweather Nicho ...... 3327

Mage Peter ............ 450

Mitchell Wm ........... $5 \mathbf{I 2}$

Marr Geo .............. 100

Moor Anne ............ 75

Mutray Tho ........... 382

Mirideth James ......... 270

Molan WVarwick ......... 850

Muttlow James ........... I50

Morgan Matthew ......... 2 Io

Morris John ........... 450

Markham Tho .......... I00

Moxon Wm ............. 100

Mackony Elizb .......... 250

Meacon Gideon ......... 270

\section{$161491 / 2$}

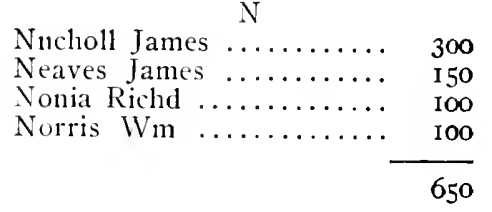

O

Osling John ........... I50

Oudton Matt ........... I9o

630

$\mathrm{P}$

P 400

Pendexter Geo ........... 1490

Pattison David .......... 300
Otey John ............. 290

$P$ 
Park Jno Junr ...........

Park John ...............

Pease John ..............

Philip Geo ...............

Penix Edwd .............

Plantine Peter .............

Pendexter Tho ............ I000

Pyraul James ........... I50

Pullam Wm ............ 575

Purdy Nicho ........... 200

Page Mary Madm ....... 3450

Perkins John ........... I 20

Paite Jerim ............ 220

Pasley Robt ............ 300

Perkins IVm ............ 305

Pait John .............. I I $_{500}$

Petever Tho ............. 100

Pittlader Wm ............ I.47

Pickley Tho $\ldots \ldots \ldots \ldots \ldots$ 28. 28

Pittlader Tho ........... 295

Petty Stephen ........... 200

Porter John ............ I00

Petty John ............ 2190

Park Coll ............. 7000

Purly John ............. 100

21573

\section{$\mathrm{R}$}

Raglin Evan ........... 300

Raglin Evan Junr ......... I00

Raglin Tho ............. I00

Ross Wm ............... 150

Richardson Henry ....... 300

Raymond James ......... So

Reynold Tho ............ 255

Reyley Jno ............. 100

Reynolds Jonah ......... 50

Rhoads Charles .......... I75

Reynolds Samll ......... 820

Rice Tho .............. 300

Redwood John .......... I078

Rule Widdo ............. 50

Richardson Richard ...... 890

Russell John ............ 550

Richardson John ......... I I 450

Richard Eman ............ 1250

Round Free $\mathrm{Wm}$........ 100

Randolph Widdo ......... 100

8928

$\mathrm{S}$

Styles John .............
Smith Nathll ......... 82

Sanders IVm ........... 40

Spear Robt ............. $45^{\circ}$

Sanders James .......... 60

Scott John ............. 300

Scrugg Richd ........... I00

Strange Alexander ....... 450

Smith $W m$............. I IO

Scrugg Jno ........... 50

Snead Tho ............ 200

Sunter Steplien ......... 478

Symons Josiah .......... 100

Sanders John ........... I30

Stephens Wm .......... IOo

Stanley Tho ............ I50

Sandidge Jno ........... I00

Sprattlin Andrew ........ 654

Snead John ............. 75

Smith James ............ so

Sexton $\mathrm{Wm}_{\mathrm{m}} \ldots \ldots \ldots \ldots \ldots \ldots$ \&.... \&o

Sims Ino ............ I000

Smith Roger ........... 300

Sherritt Henry ........... I00

Salmon Thomas ......... 50

Sanders Tho ........... 25

Symons George ......... 12.5

Stamp Ralph ........... 625

Stanop Capt ........... I024

Stanup Richd ........... 325

Shears Paul ............. 200

Stepping Tho ............ 350

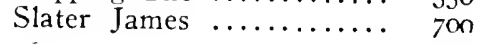

9813

\section{$\mathrm{T}$}

Tony Alexandr .......... I I

Tovis Edmd ............. IO

Turner Henry ........... 250

Turner Wm .............

Turner Geo .............

Thorp Tho $\ldots \ldots \ldots \ldots \ldots \ldots, 200$

Thurmond Richd ......... $13 I^{1 / 2}$

Tucker Tho …......... 700

Turner James ............

Thompson James ........

Tully Wm ............. 200

Turner Geo Junr ........... 200

Tate James ............

Town Elizb .............. 100

Thomasses Orphans ..... 500

Tinsley Cournelius ....... 220

Tyler ............... 


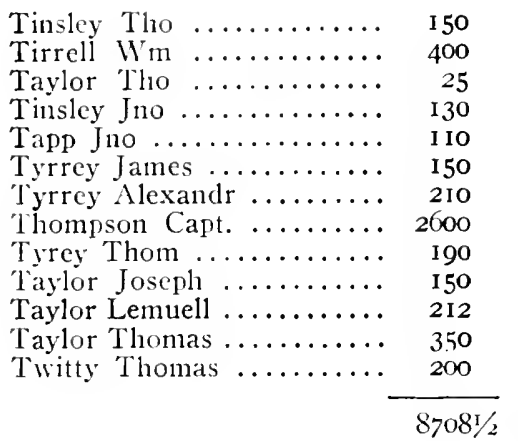

V

Upsherd Jon ............

Vaughan Wm ............

Via Amer..............

Venables Abr. .............

Venables John ...........

Vaughan John ............

Vaughan Vincent ........ 410

1370

IV

Wintby Jacob ...........

Winfry Charles ...........

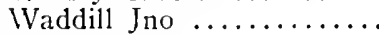

Walker IVm ..............

Walton Edwd ............

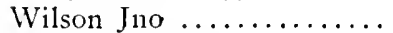

Waddill Wm ...............

Warring Peter .............

Wingfield Tho ...........

Weaver Sam .............

Wyatt Alice ..............

West Nath ..............

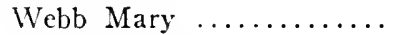

Wilmore Jno .............

Webster Joseph ...........

West Giles ................

Wharton Tho ..............

Willis Fran .............

Waddy Samll .............

Willford Charles .........

Waid James ............

White Jno ................

Wood Henry ..............

IVoody Symon .............

Woody Jno ...............

250

100

40

650

I 50

200

375

88

I 50

100

I 300

6370

200

100

80

200

270

134

150

100

150

320

IOO

50

100
Winstone Antho .........

Winstone Isaac ..........

Woody James .............

Winstone Sarah ..........

Watson Theophilus ........

VVoodson Jno .............

Walton Edwd .............

Wood Walter .............

Vatkins Wm .............

Wilkes Joseph ...........

Williams Clerk .......... 300

Willis Stephen ......... 500

Williams Tho .......... I00

Worrin Robt ........... 300

Woodull James ......... 200

Walker Capt ............ 400

Wilson James ........... 60

Wheeler John ........... 75

Williams Wm. .......... 100

White John ........... I90

17292

$\mathrm{Y}$

Ycoman John ......... 50

Yeoell Judith ........... 150

200

o

0

0

o

5

90

o

Quit Rents that hath not been paid this 7 year viz.

Richarson Matt .................

Wm Wheeler ............

Coll Parkes ........... 300

650

Lands that the Persons lives out of the County viz.

Coll Lemuell Batthurst .... 800

Robt Valkes ........... 500

The Heirs of Bray ....... 500

1800

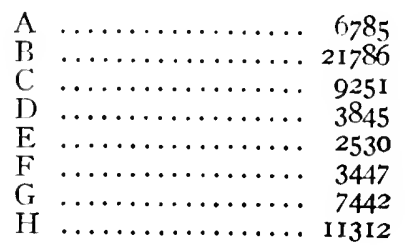


J $\quad \ldots \ldots \ldots \ldots \ldots, 5838$

K $\ldots \ldots \ldots \ldots \ldots \ldots, 2490$

L $\ldots \ldots \ldots \ldots \ldots \ldots+14760$

M $\ldots \ldots \ldots \ldots \ldots$ I6I $49 \mathrm{I} / 2$

$\mathrm{N} \ldots \ldots \ldots \ldots \ldots, 650$

O

P $\ldots \ldots \ldots \ldots \ldots \ldots+21573$

$\mathrm{R}$................ S298

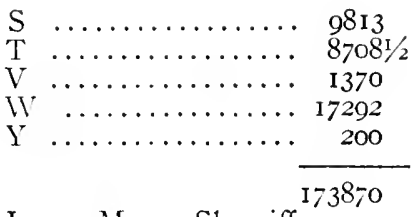

James Mosse Sherriff

A full \& Perfect Rent Roll of all the Land held of hor Majtie in Charles City County this Present Year 1704 by Patents \&c.

\section{A}

Aliat John

$\mathrm{B}$

Bradley Joseph ............

Baxter John ...............

Botman Harman ......... IO

Burton Henry ... . . . . . . . . 100

Burwell Lewis .......... 8000

Brooks Robt ............ I50

Blanks Richard Senr ..... 250

Blanks Richd Junr ........ I25

Blanks Tho ............. I25

Bradford Richd .......... I 1397

Brown Marmaduke ........ I00

Bray Darid ............. 230

I I 337

C

Cole Robt ............. 80

Codell Richd ............. $\quad$ I00

Clark Edwd ............... $\quad 9621 / 4$

Clark Daniell ............ 250

Clark Joseph ............ 230

Christian Tho $\ldots \ldots \ldots \ldots$. I 273

Cock Edwd ............... 350

Cock Richd ............. 975

$\mathrm{D}$

Davis Thomas ......... 200

Davis Richd ..............

Edwards John

Epes Littlebury ..............
Epes John .............. 500

Ele Samll ................ 682

Evans John ............ 800

$2669^{1 / 2}$

\section{F}

Floyd Geo ............. 243

Fowler Richd ............ 150

Flowers Samll ......... 200

593

G

Gium James ........... 250

Grosse Edwd ........... 100

350

$\mathrm{H}$

Hamlin Jno ............. I $143^{1 / 2}$

Hill Edwd .............. 2100

Haynes Nicho ........... $\quad$ I25

Harwood John ........... 100

Howood James ............. 200

Hattle Shard ........... II2

Harwood Joseph ......... 659

Harwood Samll ......... 350

Harwood Robt ............ $33_{3122^{1 / 2}}$

Hunt $\mathrm{Wm} \ldots \ldots \ldots \ldots \ldots$. 3130

Hunt John ...............

Harmon Elizb ............. 479

Hyde $\mathrm{Wm}$...............

Hamlin Stephen ........... 80

Hamlin Tho ........... 264

16015

$\mathrm{J}$

$287^{1} / 2 \quad$ Irly $W / m \ldots \ldots \ldots \ldots \ldots$ I0

$400 \quad$ Javox James .............. 100 
Jordin Edwd ........... I00

Justis Justinian ............ 200

$5 \circ 3$

$\mathrm{L}$

I.owlin Danll ............ 6 600

Lawrence James

700

$M$

Manders James ......... I00

Minge James ........... 1086

Mountford Jeffry ......... 100

Marvell Tho ............. 1238

Moodic Samll ............ ${ }_{82}$

Muschamp John ........ so

2686

$\mathrm{N}$

New Edwd

New Robt

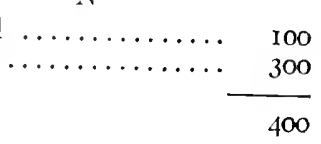

$\mathrm{O}$

Owen $\mathrm{l} \mathrm{m}$

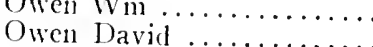

I00

100

200

Parker Tho .......... I667

Parish $1 \mathrm{Vm} \ldots \ldots \ldots \ldots \ldots \ldots$ I66\%

Parish Charles ............

Parker James ............ 100

Parish Edwd .............. I0

Parish John $\ldots \ldots \ldots \ldots \ldots \ldots$. 100

2227

Roach Ino Senr $\begin{aligned} & \mathrm{R} \\ & \ldots \ldots \ldots \ldots\end{aligned}$

Renthail Joseph .......... $\quad 630$

Rissell Samll ............ 250

Roper John ............. 253

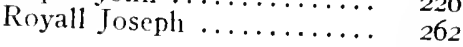

I635

S

Smith Obidiah .......... I00

Sampson IViddo .......... 2 I I

Stith Drewry ........... I 240

Stith John ............ I395

Stockes John ............ 476

Stockes Silvanus Senr ..... 250

Stokes Silvanus Junr...... 550

Speares Geo ........... ${ }_{225}$

4447

$\mathrm{T}$

Tanner Tho ........... 2000

Tarendine John ..........

Turner Edwd .............. I95

Trotman Anne .......... I 20

2465

Vernon Walter $\begin{aligned} & \mathrm{V} \\ & \text { V....... } 240\end{aligned}$

W

Myatt Widdo ........... 800

W'oodam Tho ............ 100

Waren John ........... 54

954

A $\ldots \ldots \ldots \ldots \ldots \ldots \ldots \ldots, 100$

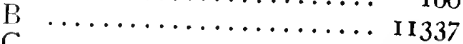

C $\ldots \ldots \ldots \ldots \ldots \ldots \ldots \ldots, 3258$

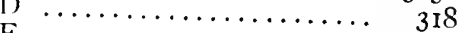

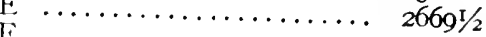

F $\ldots \ldots \ldots \ldots \ldots \ldots \ldots \ldots \ldots, 593$

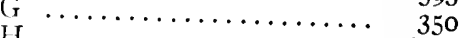

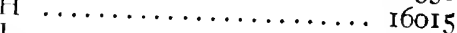

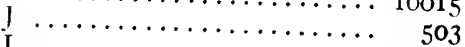

L $\ldots \ldots \ldots \ldots \ldots \ldots \ldots, 700$

M $\ldots \ldots \ldots \ldots \ldots \ldots \ldots \ldots, 2686$

$N \quad \ldots \ldots \ldots \ldots \ldots \ldots \ldots, 400$

O $\ldots \ldots \ldots \ldots \ldots \ldots \ldots \ldots, \quad 400$

P $\ldots \ldots \ldots \ldots \ldots \ldots \ldots \ldots, 2227$

R $\ldots \ldots \ldots \ldots \ldots \ldots \ldots \ldots$ I6 635

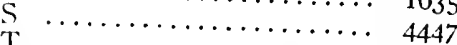

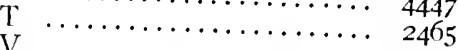

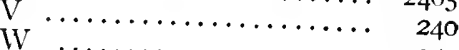

W $\ldots \ldots \ldots \ldots \ldots \ldots \ldots, 954$

$520591 / 2$ 
An account of what Land that I cannot get the Quit Rents the Persons living out of the County

Josep Parish at Kiquotan...
Richd Smith James City Cty

Danll Hayley ............

Wm Lagg Henrico Cty ....

Tho Parker Sherif
350

200

100

The Quit Rent Roll of King William County

\begin{tabular}{|c|c|c|c|}
\hline Armsby John & 200 & Coates Wm & \\
\hline Alvey Robt .............. & 400 & Douglas Wm & \\
\hline 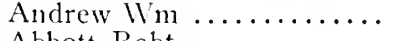 & 100 & Davis Lewis ... & \\
\hline Abbott Robt ............. & 100 & Daris $W^{m} \ldots \ldots \ldots \ldots \ldots$. & \\
\hline Arnold Anthony $\ldots \ldots \ldots \ldots$ & IOO & Downer John ........... & \\
\hline Arnold Benj .... & 1000 & Downes Elias $\because \ldots$ & \\
\hline Alcock John..$\ldots \ldots \ldots \ldots$. & 190 & Davenport Davis $\ldots \ldots \ldots$. & \\
\hline Adam James ............. & 400 & Dorrell Sampson Qr . . . . & \\
\hline Anderson $\mathrm{Wm}$ Capt ....... & I 50 & Darenport Martin ........ & \\
\hline Burwell Majr ............ & 4700 & Davis Robert ............ & \\
\hline Bunch Patıl ............ & I 50 & Dickason Wm ........... & \\
\hline Baker John,$\ldots \ldots \ldots \ldots$ & 250 & Dickason Thomas ........ & \\
\hline Burges Edwd ............ & 150 & Dillon Henry $\ldots \ldots \ldots \ldots$ & \\
\hline Buttris Robt $\ldots \ldots \ldots \ldots \ldots$ & 400 & Dabney lames..$\ldots \ldots \ldots$ & \\
\hline Bibb Benj $\ldots \ldots \ldots \ldots \ldots$ & 100 & Dabney George $\ldots \ldots \ldots \ldots$. & \\
\hline Browne Joseph .......... & $2 \% 0$ & Dabney Benj ........... & \\
\hline Edwds $\ldots \ldots \ldots \ldots \ldots$ & 580 & Davis John $\ldots \ldots \ldots \ldots$ & \\
\hline Burch Henry . .......... & 200 & Elly Richd $\ldots \ldots \ldots \ldots \ldots$ & \\
\hline Burrel Suprian .......... & 350 & Egny Elizb $\ldots \ldots \ldots \ldots \ldots$ & \\
\hline Baker Tho ............. & 100 & Elliot Thomas $\ldots \ldots \ldots \ldots$. & \\
\hline Elizb $\ldots \ldots \ldots \ldots \ldots$ & 200 & Edward James...$\ldots \ldots$. & \\
\hline Bird Wm Maj Qr ....... & 1200 & Elliott James..$\ldots \ldots \ldots$ & \\
\hline Burrus John ............. & 60 & Fox John Capt. ......... & \\
\hline Butler Thomas $\ldots \ldots \ldots$. & 150 & Fox Henry .............. & \\
\hline is Thomas $\ldots \ldots \ldots \ldots$. & 60 & 11 Francis ........... & \\
\hline Bassett Coll Qr ......... & I 550 & Fuller Anthony $\ldots \ldots \ldots$. & 10 \\
\hline James Qr .......... & I. 100 & Foord John Junr ......... & \\
\hline rahan $\ldots \ldots \ldots$ & 250 & $W n 1, \ldots \ldots \ldots$ & \\
\hline vell Elizb .......... & 300 & Futlatove Thomas ......... & \\
\hline Bickley Joseph ........... & I 50 & Fleming Charles Qr...... & \\
\hline rne $1 \mathrm{Vm}$ Coll ....... & 3000 & Graves John Qr $\ldots \ldots \ldots$ & \\
\hline rne Tho Capt.... . & 1000 & att Thomas...$\ldots \ldots$. & \\
\hline rne John....... & 50 & Geeres Thomas .......... & \\
\hline Robert $\ldots \ldots \ldots \ldots$ & 100 & John $\ldots \ldots \ldots \ldots \ldots$ & \\
\hline ck Samll & 600 & att Henry ...... & \\
\hline am $W m \ldots \ldots$. & 200 & Goodin Majr Qr ... & \\
\hline m Joseph ......... & 600 & Glover $W \mathrm{~m} \ldots \ldots \ldots$ & Io \\
\hline John $\ldots \ldots \ldots \ldots \ldots$ & 100 & Herriott George ...... & \\
\hline wick Wm $\ldots \ldots \ldots \ldots$ & I 50 & Hollins John ........ & \\
\hline John $\ldots \ldots \ldots \ldots$ & I 80 & son Joln $\ldots \ldots$. & \\
\hline & 500 & rbee $W_{m} \ldots \ldots \ldots$ & $10 \mathrm{r}$ \\
\hline & 700 & Holliday Wm ............ & I0 \\
\hline haw Thomas ........ & 150 & Hayfield $1 / \mathrm{m} \ldots \ldots \ldots$ & \\
\hline Clark. & 100 & Hampton John ...... & \\
\hline
\end{tabular}


Huckstep Edwd ......... I50

Hurt W'm Junr ..........

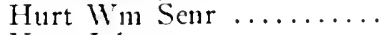

Hurt John ...............

Hendrick Hans ..........

Handcock Thomas ........

Hayden John .............

Hobday Edwd .............

Hill Thomas .............

Hutchinson Wm ..........

Hill Francis .............

Hill Gabriell .............

Hill Edwd Coll Qr ........

Hayle Joseph ............

Johns Jane ..............

Johnson IVm .............

Johnson Coll Qr ..........

Johns Wm ................

Isabell $\mathrm{Wm}$................

James Jonathan ...........

Inge Vincent .............

Jones Frederick Qr ........

Jenings Coll Qr $\ldots \ldots \ldots \ldots$

King Robert Q̊ $\mathrm{r}$............

Kettlerise Symon ...........

Lee John ...............

Lypscomb Ambrose ........

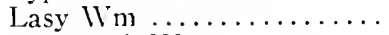

Lypscomb $\mathrm{I} \mathrm{m}$...........

Littlepage Richd Capt Qr ..

Lypscomb John ..........

Mallory Thomas ..........

Mallory Roger ...........

Miles Daniell .............

Mr Gehee Thomas ........

Marr John ...............

Morris Wm .............

Maybank Wm ............

Mr Donnell John .........

Maddison Henry ..........

Merriweather Nicho Qr ...

Mullene Matthew .........

Madison John Qr ........

Norment Joseph .........

Norment Samll ...........

Noyce $\mathrm{Wm}$..............

Napier Robert .............

Owens Hugh .............

Oustin Jolnn .............

Oakes John ..............

Oliver John ..............

Palmer Martin ..........

Peck John ..............
Pyncs Nathaniell ........ 1400

Pee Thomas ........... $\quad 400$

Purlcvant Arthur ........ 100

Powers David .......... 200

Pollard IVm Qr......... 500

Pemberton Geo .......... 180

Page John Qr ........... 1000

Pickrell Gabriell .......... Ion

Parks Coll Qr .......... +500

Quarles John ........... 100

Reynolds $\mathrm{W} m$.......... 100

Robert Maurice ......... 200

Randall John ........... 100

Ray James ............. I00

Rhodes Nicholas ......... 150

Sandlan Nicholas ......... 700

Strutton Thomas ........ 150

Streett Wm ............ 350

Shilling George ......... 300

Satterwhite Charles....... 150

Slaughter Geo ........... IO0

Slaughter Martin ........ 130

Stark John ............ 500

Sanders Jushua .......... 100

Sce Mathew ............ 200

Sellers Jacob ............ 350

Spruse Jeremy .......... 150

Smith Edmd ............ I50

Spencer Thomas ......... 600

Slaughter John .......... no

Smith Christo $\mathrm{Qr} \ldots \ldots \ldots \quad 800$

Slaughter Henry .......... I00

Toms $11 \mathrm{~m} \ldots \ldots \ldots \ldots .150$

Towler Matthew ......... 150

Terry Thomas ......... 300

Terry Stephet1 .......... 330

Tomason Thomas ........ 150

Terry James ........... 400

Traneer John ........... 100

Vickrey Henry ......... 450

West John Coll .......... 1800

Winfree Henry ......... 300

West Tho Capt ........... 1000

Whitworth John ......... 200

Whitlock John ........... 200

Willeroy Abraham ........ 550

Williams Phillip ......... IO

Williams Griffith ......... 240

Wood Thomas .......... 300

Whitelsead John $1 . . \ldots \ldots \ldots$. 100

Woolsey Jacob ............ 130

Williams John .......... I50

Williams Samll ......... 600 
Wright Thomas .......... I50

Whitbce Robert ......... 800

West Nathanll Capt ...... 2000

Waller John Majr ........ 800

Willis $\mathrm{Wm} \ldots \ldots \ldots \ldots . .250$

Wheelis Joseph ......... 130

Wormley Madam Qr ..... 3000

Winston William ........ 170

Whiteliead Phillip ........ 3000

Yancey Charles .......... 100

Yarborough Jolin ......... 150

Yarborough Richard ..... 300
Wim Stanard M.S. ....... 1000

James Wood K.Q. ........ 500

Zachary Lewis K.Q. .... $45^{\circ}$

Peter Kemp G.C. ......... 600

$1 \mathrm{Wm}$ Beck N.K. ......... I600

Tho. Hickman K.Q. ...... 550

Benj Clement G.C. ........ 600

David Bray J.C.C. ....... 1000

Job House N.K. ........ 2000

Harry Beverley M.S. ..... 600

Chillian White G.C. ...... 300

100950

A True Account of the Lands in King \& Quecn County as it was taken by Robt. Bird Sherriff in the year 1704.

\section{A}

Alford John

Austin Danl

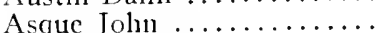

Adanis Johiss ..........

Arnold Edwd ...........

Allin Thon $\ldots \ldots \ldots \ldots \ldots$.

Adkinson John $\ldots \ldots \ldots \ldots \ldots$

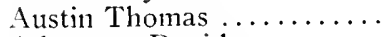

Adamson David ........

Anderson Richd ..........

Allcock Dorothy ........ 150

2300

\section{B}

Baker $W$ m ............ 350

Beverley Robt. Qr. ....... 3000

Bennett Alexander ........ 200

Breeding Geo ............ 200

Bennett Wm ............. 150

Bowles Robt ............ 100

Bennett Sawyer ........... 150

Baylor John ............ 3000

Bell Roger ............... ${ }_{150}$

Burford Wm ............. 150

Bray John ............... 230

Blake $W m \ldots \ldots \ldots \ldots \ldots . .290$

Boisseau James Quart ...... 900

Blake $W \mathrm{~m}$ Junr ......... 210

Brown Lancelet .......... 385

Burch Ino .............. 100

Burch Wm ............ 100

Brown Tho. Blakes Land .. 300

Bridgeforth James ....... 355
Bagloy Robt ........... 550

Banks Wm ............ 10

Bullock John ............ 200

Bird $1 \mathrm{Vm} \ldots \ldots \ldots \ldots \ldots \ldots .572$

Broach Jno ............ 1200

Braxton Geo ........... 2825

Blanchet John .......... 125

Bowker Ralph ......... 330

Bine Ednd ............ I I I

Barber James .......... 750

Burgess Wm .......... 100

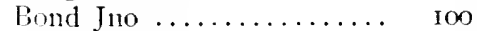

Breemer John .......... I I00

Bland Henry .......... 150

Breemer John Jumi ...... 200

Bowden Tho. .......... I50

Barton Andrew ........ $\quad 150$

Barlow Henry .......... 200

Baskett John ........... I50

Batterton Tho........... 100

Baker James ........... 322

Bill Robt. ............. $\quad$ i 50

Bocus Reynold .......... 150

Bourne George ......... 200

Bird Robt. ........... I324

22535

Cane J110 ............. 300

Chessum Alexandr ....... 150

Cook Benjamis ........ 200

Cook Thomas Junr ....... 50

Cook Thomas Senr ...... 100

Cook Jno ............ 50

Cleyton John ......... 400 


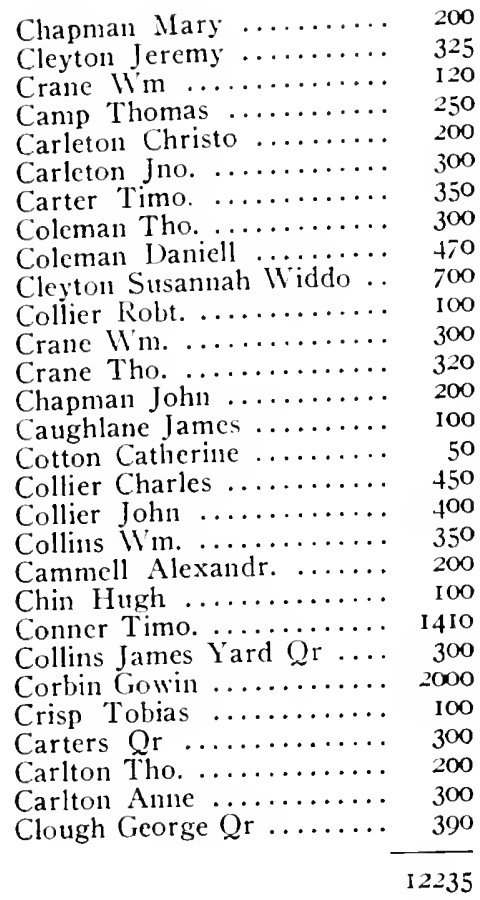

Clerk and Cordell both

in Glocester ........... I000

\section{D}

Widdo Durrat ............. Day Alexander Maj.

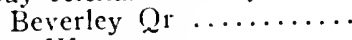

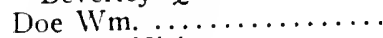

Dilliard Nicho. ..........

Dilliard Edwd. ............

Dimmock Tho. ...........

Dismukes W'm. ..........

Duett Charles ............

Didlake James ...........

Durham Jolnn ............

Dunkley John ............

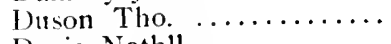

Davis Nathll. ............

Deshazo Peter ............

Davis Jno ...............

Davis Edwd
200

300

300

150

150

150

200

900

200

100

380

448

300

450

90

100
Dillard Thomas ........ 170

Davis Richd ........... 250

Dillard Geo ............ 325

Duglas James .......... 275

Dayley Owen ........... 180

$\mathrm{E}$

5618

Eachols John ............

Ellis John ...............

Eastham George ..........

Ewbank IIm ...............

Eastham Edwd Junr .......

Edwds John .............

Easthan Edwd ............

Eastes Abraham ...........

Eyes Cornelius .............

Emory Ralph ............

Ellis Timothy ...........

\section{F}

220

400

300

350

800

100

100

200

100

100

350

3020

Forsigh Thomas ........ I50

Farquson James .......... 300

Flipp John ............ 80

Farish Roht ............ I 400

Fielding Henry .......... 1000

Farmer John .......... 50

Fothergill Richd ......... 675

Fortcon Charles ......... 400

Forgett Charles .......... 150

Robt Fothergill ......... I50

\section{$+355$}

Farmer John not paid for.. Fox Margarett not pd for..

200 100

\section{G}

Gadberry Edwd ...........

Griffin Edwd .............

Greorge Richd .............

Griffin David ............

Graves Robt .............

Graves Jilo ...............

Gardner Ringing ..........

Gray Joseph .............

Gilby John ..............

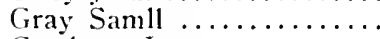

Gresham Ino ............

Gresham Edwd ............

Good John ...............

Gresham George .........
100

100

100

100

150

I 50

200

200

300

10

200

I 75

200

I 50 
Garrett Danll

200

Gamble Tho. Majors Land Gresham Tho ........... Graves Jno ........... Guttery Jno ............ Greogory Frances Widdo .. Gough Alice Widdo ...... Griggs Francis .......... Garrett John ........... Garrett Humphrey ....... Gibson IViddo .......... Garrett Robt ...........

6100

\section{$\mathrm{H}$}

Hand Thomas ............

Hayle John Qr ...........

Honey James .............

Holloway W'm ............

Herndon James ...........

Hoomos George ..........

Hodges Thomas ..........

Hayle Joseph ............

Hayes John .............

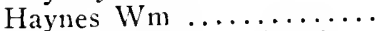

Holcomb $W \mathrm{~m}$ Bradfords

Land .....................

Henderson Joln Thackers

Land ..................

Hodgson Widdo ...........

Henderson Widdo ........

Henderson $\mathrm{Wm}$...........

Housburrongh Morris, Harts

Land .................

Hesterley John ..........

Hill John ................

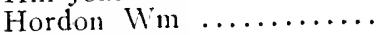

Harris $W_{m}$..............

Hart Tho .................

Hockley Robt ...........

Howard Peter ............

Hardgrove $\mathrm{W}^{\mathrm{m}}$............

Herring Arthur ..........

Hickman Thomas ........

Hunt Wm ..............

Hobs $\mathrm{Wm}$...............

Hicks Richd ..............

Howden IVm .............

Howerton Thomas ...... 300

150

685

200

100

100

725

250

250

IOO

494

700

200

200

300

I62

200

200

200

70

250

200

100

300

IOO

50

700

312

250

250

100
Holt Joseph lives in

Maryland ............ 32I

Mayward Tho in Glocester. . 600

\section{$\mathrm{J}$}

Jones Tho ............. I50

Jones Roht ............. 200

Jeffrys Richd ........... 337

Jones Robt Juur ......... I30

Johnson Jannes .......... 200

Jones $\mathrm{IVm} \ldots \ldots \ldots \ldots \ldots \ldots 900$

1917

$\mathrm{K}$

King John ........... I50

Kallander Timo .......... 100

Kink Anne .............. 275

King Edwd ............. 200

Knowles Dorothy $\mathrm{Qr} \ldots \ldots$ I 50

King Robt .............. I00

Kenniff Danby ............ 100

King Daniell ........... 200

I335

L

Loveing John ........... 100

Lyon Peter ............. 250

Leigh John ........... 6200

Lumplin Robt ........... 400

Lee $I \mathrm{Vm} \ldots \ldots . \ldots \ldots . . .230$

Loob Wm .............. IO0

Loft Richd ............... 320

Lowis Tachary........... 350

Lumpkin Jacol ........... 950

Lewis David ............ 120

Lewis John Esq .......... 10100

Lewis Edwd ............. I 100

Lemon Elizb ........... 100

Lynes Rebecea ........... 405

Levingstone John ........ 600

Levingstone Samll ........ I00

Lawrence Matthew ....... 210

Letts Arthur ........... 475

Langford John .......... 150

Levingstone Jno Sowels

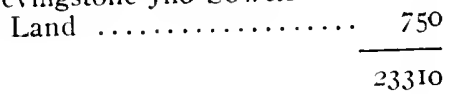

Leftwich Thomas in Essex 75 
M

May John ...............

Mnsick George ...........

Major Jno ..............

.Martin John ............

Nore Ninstines (yr ........

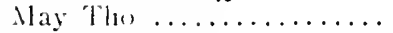

Mrore Samll ...........

Maddison Jno ............

Morris Wm .............

Martin Elizb .............

Nackay Sarah ...........

May John Piges Land ....

Major Francis ...........

Mansfield Thomas ........

Morris Henry ...........

Major John .............

Melo Nicho ..............

Marcartee Daniell ......... 200

Morris $11 \mathrm{~m}$........... 300

Mead Wim ............. I00

Matthews Edwd ........... I60

Martin Cordelia II ido ... 200

5377

$\mathrm{N}$

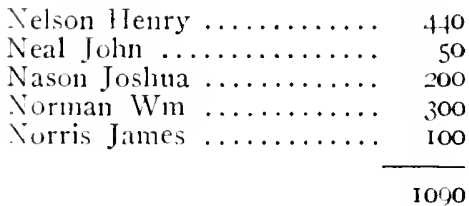

$\mathrm{O}$

Owen Ralph $\ldots \ldots \ldots \ldots \ldots$

Ogilvie Wm ..............

()rrill Lawrence ..........

()rrill W'm ..............

Orsbourn Michaell .......

Orerstreet James Qr .....

ditto at home .............

120

300

290

500

90

I 80

50

1530

$\mathrm{P}$

Powell Robt

Prewitt $W m$.................

Paine Bernard .............

Pomea Francis ...........

Philip Charles ............

Pettitt Thomas
Pollard Robt ............

Pollard IIm ............

lhinkett Elizb .............

Pemberton Tho. ...........

Pickles Tho .............

Putters Francis Wido

$N$ eals Land ........... 100

Parks James ........... 200

Purchase Cieo $Q r \ldots \ldots \ldots \ldots$. 580

Page Ino .............. I00

Pritcliett David .......... 225

P'igg Henry ........... $6 \mathbf{6}$

Page John Junr ......... 300

Pigg Edwd ............ 250

Phelps Tho ............. 400

Pendleton Philip ......... 300

Pendleto Henry ........ 700

Pann John ............ 200

Paytons quarts .......... 500

Pigg John ............. I00

Pamplin Robt .......... I 50

Pryor Christo ........... 175

I'aulin Elizb .......... 175

Pate John in Glocester..... $\quad \begin{array}{r}7552 \\ 1000\end{array}$

$Q$

Quarles James .......... 300

Quarles Dyley Zacha:

Lewis Land ......... 300

600

\section{$\mathrm{R}$}

Richard Robt ......... 300

Rings Quarter ........... I000

Robinson Daniel ........ I00

Roger Giles ............ 475

Rice Michaell .......... 200

Richeson Tho .......... 460

Richeson Elias .......... I80

Read Elizb ............. 550

Russell Alexandr Wyatts

Land ............... 400

Robinson Robt .......... 980

Rowe John ............. 100

Richards John .......... 9It

Richards $1 \mathrm{Wm} . . . \ldots \ldots \ldots$ 400

Richards Oliver ......... 250

Riddle Tho Reads Land ... 700

Roy Richd ............. I000

Ryley Elias ............ 200 
Rollings Peter ........ I50

John the son of Robt

Robinson hold, which

nobody pays for ........

\section{$\mathrm{S}$}

Sebrill John ............ I 30

Stone Mary ............. I00

Simiths in Bristoll Qr .... 2800

Stone Jno ............. 295

Stubbeifield Geo Qr ...... 400

Scandland Denis ......... 1470

Swinson Richd ......... I70

Smith Christo ............ 200

Simith Jno Cooper ....... 27.3

Smith Alexander ......... 275

Seamour Wm ........... 268

Sones Tho ............ I50

Shepard Jane ........... 100

Southerland Danll ....... $\quad 200$

Shoot Tho ............. 100

Shepheard Joseph ........ Ioo

Shea Patrick ............ 200

Snutherland Danll ........ 200

Smith Nicho ........... 700

Sanders Nathll ........... 200

Smith John Sawyer ....... 80

Shuckelford Roger ....... 250

Skelton John ........... I00

Snell John ............. I50

Simpio Charles ........... 100

Sawrey John ............. I13

Stringer Margt ......... 175

Spencer Tho ............ 300

Sykes Stephen .......... 50

Snith Francis .......... I00

Smith Richd ............ I 50

Sparks John ........... 200

Surly Tho ............ I00

Stapleton Tho ........... 200

Story John ............ 3000

Spencer Katherine ........ 600

14599

Shippath Sr Wm Which is not paid for ............

Stark Tho of London which is not paid for ..........

Stubblefield Geo in Glocester Smith Austin in Glocester..
$\mathrm{T}$

Turner Richard ......... 200

Todd Thomas Quarts .... 2300

Taylor James ............ 4000

Toy Thomas .......... 175

Taylor Danll .............

Thomas Rowland ........ 610

Tunstall Tho $\ldots \ldots \ldots \ldots \ldots$. 550

Todd Richd ............ 1050

Towley John ........... 200

Trice Jati1es ........... 350

Tureman Ignatius ....... I00

Turner Thomas ......... 267

Thacker C. C. .......... I000

10872

$\mathrm{U}$

Vaughan Cornelius ...... 500

Vize Nathll ............ IOO

Uttley John ............ 200

800

Wood James ............ Soo

Wilkinson John ......... 100

Wright Tho ........... 300

Watkins Wm ........... I37

Wiltshier Joseph ........ 6o

Watkins Edwd ........... g8

Watkins Philip ........ 203

White Thomas ......... 200

Walker John ............ 6000

Wilson Benj Wyats Land.. 420

Wyat Richd ........... 1843

Walton Thomas ........ 200

Wyat John ............ 530 b.

Withy Thomas ......... 50

Willians Thomas ....... 200

Watts Tho ............ 235

Ward Samll ........... I60

Watkins Benj ........... 60

Watkins Tho Jun! ....... I 25

Williams Elizb ......... 900

Waldin Samll ............ 275

Ware Edwd ............ 735

William John .......... I 125

Ware Vallentine ......... 487

Willbourn Tho ......... 250

Wildbore $\mathrm{Wm}$........... I00

Ware Nicho ............ 7 I 8

White Jerimiah ........ 200 
Whorein John

Watker fond quarts ........

209

Waker John, Johnsons

l.and

Nadlington Paul not paid

I0920

for being

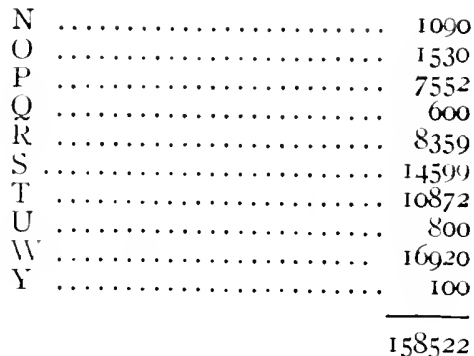

York Matthew $\mathrm{Y}$

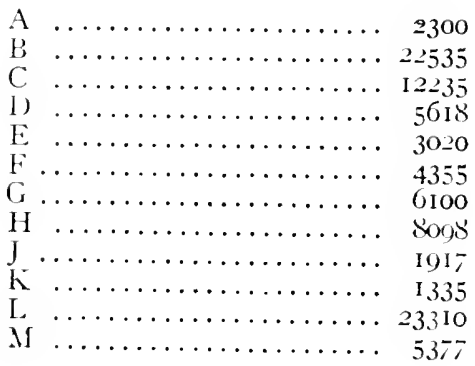

Lands returned not paid for

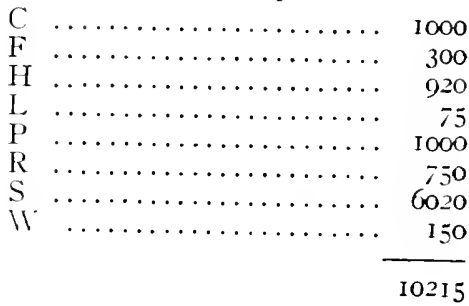

Glocester Rent Roll

A Rent Roll in Petso Parish

Capt Darid Alexander .... Io

James Amis ............ 250

John Acre ............. I00

$\mathrm{Wm}$ Armistead ......... 430

Ralph Baker ..............

Martha Brooken .......... 600

Thomas Buckner ........ 850

Samll Bernard .......... 550

Wm Barnard ........... 810

Richd liailey ............

Mary Pooker ............. 100

Thomas Cook ........... 350

Wm Crymes ...........

Jno Coison $\ldots \ldots \ldots \ldots \ldots \ldots$. 160

'Robt. Carter ........... IIO

$1 \mathrm{~lm}$ Collone ............

Hannah Camell $\ldots \ldots \ldots \ldots .6$. 100

Benj Clement ............ to

Ino Cleake ............. I0

Wm Cook ..............

Ino Coleman $\ldots \ldots \ldots \ldots \ldots \ldots$. 200

Juo Day ...............

Jerim [armell .........

Jno Darnell ...........
James Dudley ........... 780

Richd Dudley ............ 400

Thomas Dudley .......... 200

Thomas I ixon $\ldots \ldots \ldots \ldots$. 300

Tno Drument $\ldots \ldots \ldots \ldots \ldots$. 80

Samll Fowler ........... 150

$1 \mathrm{Im}$ lileming ............ 600

IVido Forginson .......... 150

$\mathrm{Wm}$ Fockner ............ 180

Jno Grymes ............. 1400

Susannah Girinley ....... 200

Darcas Green ........... to

Jno Grout ............. 300

Ino llarper .............

II'm Howard ........... 300

Richd Huhard ............

Wm Hasford $\ldots \ldots \ldots \ldots \ldots, 500$

Ino Hanes ............. I50

Alextuder How ......... I 120

Richd Hill $\ldots \ldots \ldots \ldots \ldots \ldots$ \%

Rol,t Hall ............

Richd Hull ........... 250

Sanll Hawes ........... 200

Stephen Jolinson ......... 
W'm Jones for Northington Glebe Land ............. Jno Kingson .............. Capt Edwd Lewis ......... Richd Lee Esq ........... Nicho Lewis orphen ....... Wm Milner ............. Richd Minor ............. Edwd Musgrove .......... Hayes an orphan ......... Elizb Mastin ............. Jno Mackwilliams ....... Robt Nettles ............ IIm Norman ............. Isaac Oliver ............. Dorothy Oliver .......... Jno Pritchett .............. Jno Pate ............... Richd Price ............ Madm Porteus ...........

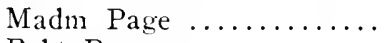
Pobt Porteus ............. Guy Parish ................

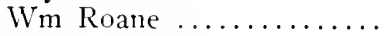
James Reynolls ........... George Robinson .......... John Royston ............ Thomas Read ........... Wm Richards in Pammnkey Jno Shackelford

530
127
400
1000
1140
350
500
250
100
60
360
50
300
150
100
130
850
1100
600
500
550
892
100
500
200
300
570
2000
150
280

280

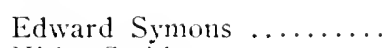

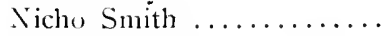

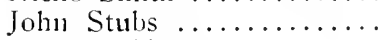

Thomas Sirepson ........

John Smith .............

Augustin Smith ..........

Augustin Smith Junr ......

Wm Starbridge ...........

IIm Thornton Senr .......

IIm Thornton Junr .......

Wn Lpsliaw .............

Francis Wisdom .........

Thomas West ...........

Thomas IVhiting ..........

George Williams .........

Conquest Wyatt ..........

Seth Wickins ...........

Walter Waters ...........

Jane Wothem ............

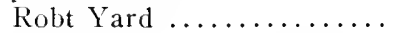

Robt Hall ..............

Wm Whittmore Desarted ..

Wm Parsons Orphen .....

Edwd Stephens ............

John Kelley Orphen .......

41132

Tho Neale

500

280

300

280

I 300

200

500

159

525

800

200

490

I 50

I 12

450

100

2200

50

200

60

450

250

150

100

70

I 50

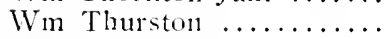

Glocester Rent Roll

A Rent Roll of Kingston Parish

Rose Curtis ............. too

Robt Peyton ............ 680

Richd Perrott .......... 35

Henry Preston ........ 1500

Sarah Green ............ 200

Robt Cully .............. 200

Thomas Hayes .......... 140

Andrew Bell .......... $\quad 128$

Humphry Toy ........... I 100

Anne Aldred..$\ldots \ldots \ldots \ldots .350$

Dunkin Bahannah ........ I $131 / 2$

Richd Hunley ........... 50

Capt Gayle .............. 164

Math. Gayle Junr ........ 250

James Hundley .......... 100

John Hundley ........... I.30

Philip Hundley ........... 6ifn
Tho Cray ............. 200

Hen. Knight .......... 240

John Williams ......... 50

Richd Beard ............ 380

Timothy Hundley ....... 300

Thomas Bedford ........ 50

Jno Floyd ............ 250

John Bohannah ......... I $33^{1 / 2}$

Capt Armistead .......... 3675

Christopher Dixon ....... 300

Roht Bristow Esqr ....... 900

Edwd Gowing ........... 100

Tho Ryland ............ 2/2

John Nevill ............ I00

Lawrence Parrott ........ 340

Wm Brooks ............. 720

Joseph Bohannah ........ I I 18 
Wm Itampton .......... 348

Widldo Gircent ........... 150

(apt 1)udley ............ 650

Capt. Knowles ...........

Capt. Tho. Todd ..........

W'm beard .............

IIm. Tomkins ..........

lleury Bolton ............

$11 \mathrm{~m}$ Eliott ..............

Humphrey Tompkins .....

I)aniel Hunter ...........

Thomas Peyton ...........

Richd Dudley ............

James Ransom Junr .......

Tho. Peters ..............

Robt. Elliott ............

Mich. Parriett ............

Jno. Meachen Junr ........

Caleb Linsey .............

Alexandr Ofield ..........

Mark Thomas .............

Jno. Garnet ............

ITm. Plumer ...............

Wm. Brumley ............

IVm. Credle .............

Charles Jones ............

Robt. Sadler ..............

Edwol Sadler .............

Geo Roberts .............

Richd Longest ...........

Tho. Fliping .............

Charles Watters ..........

Wm. Grundy .............

Thomas Kemp ............

Tho. Allaman ...........

Coll Kemp .............

Ralph Shipley ............

George Turner ...........

Coll. James Ransom .......

Thomas Putman ..........

Richd Marchant ..........

IVicklo Sinoh .............

Christopher Rispue ..... 200
Benj. Read ........... 550

Walter Keble ........... 550

Josepl Brooks ......... 500

Capt. Gwin ............. I I

Lindseys Land ......... 390

Thomas Garwood ........ 77

John Callie ............. I000

Tho. Miggs ........... 100

Riclid Glascock ......... 500

Ino Lylley ............. 584

Geo. Billups .......... I 200

Robt. Singleton .......... 650

James Foster ............ 225

John Andrews ......... 50

Thomas Rice ........... 34

John Martin ........... 200

Capt. Smith ............ 550

Capt. Sterling ........... 1100

John Diggs ........... I 200

Wm. Howlett .......... 300

Jno. Miller ........... I00

Andrew Ripley .......... 40

Francis Jarvis .......... 460

Wm. Armistead ........ 300

John Banister ........... 650

Tho. Plumer ........... 400

Isaac Plumer ........... 200

James Taylor ........... 50

Edwd Borum ........... 360

Widdo Davis ......... 300

Sam. Singleton .......... 300

Wm. Morgan Senr ....... 50

Wm. Morgan Junr ...... 200

John Bacon ........... 825

Henry Singleton ......... 60o

John Edwards .......... 534

Patrick Berry ........... 250

Anne Forest .......... 500

Ambrose Dudley

46537

\section{I705}

Glocester Rent Roll

A Rent Roll in Ware Parisl

Thomas Poole .......... 600

Amne Croxson ........... 300

Thomas Purnell .......... ${ }_{16} 6$

Nocholas Pamplin ....... 2 ro
Simon Stubelfield ........ 200

Jno. Price ............. 600

Saml. Vadrey .......... 400

Samll Dawson .......... 350 
Nathan: Burwell .......... John Dawson ............. Tho. Bacop ............... Robt. Francis ............ Walter Greswell .......... Tho. Read ................. James Shackelfield ......... Robt. Freeman ............

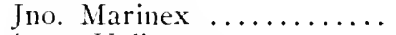
Isaac Valine ............... Tho. IIaywood ........... Hugh Marinex ........... Leonard Ambrose ......... Philip Grady ............ Capt. Wm. Debnam ....... James Burton .............. Jno. Spinks ............... Wm. Hurst ............. Sarah More ............... John Ray ............... Robt. Pryor .............. Christo. Greenaway ....... Capt. Throgmorton ......... James Clark .............. Philip Cooper .............. Jno. Kindrick .............. Samll. Simons ........... Wm. Radford ............... John Robins ............... Alice Bates .............. Jno. Easter ............... James Davison ............ Robt. Morrin .............. Anne Bray ................. Grace Easter .............. Samp-on Dorrell ........... Capt. Francis Willis ......... Thomas Powell ............. Wm. Holland ............. Capt. Cook ...

$\begin{array}{r}600 \\ 780 \\ 200 \\ 400 \\ 50 \\ 400 \\ 35 \\ 135 \\ 100 \\ 100 \\ 70 \\ 50 \\ 200 \\ 200 \\ 1250 \\ 100 \\ 300 \\ 200 \\ 67 \\ 100 \\ 300 \\ 270 \\ 500 \\ 250 \\ 200 \\ 100 \\ 120 \\ 200 \\ 900 \\ 200 \\ 350 \\ 100 \\ 200 \\ 100 \\ 200 \\ 300 \\ 3000 \\ 460 \\ 300 \\ 1500 \\ \\ \hline\end{array}$

Giles Cook .................... 140

Wm. Jones ............. 120

Tho. Collis ............ 100

Philip Smith .......... 700

Tho. Cheesman ......... 650

Gieo. More ............. to

James Morris .......... 250

Abraham Iveson Senr. .... I000

Robert Bristow Esqr. ..... 2050

Anthony Gregory ......... 700

Richd. Bailey ........... 800

Wm. Foulcher ......... I00

Widdo. Jeffes ........... 216

Richd. Dudley Junr. ..... 300

John Buckner ........... 900

Thomas Todd .......... 884

John and Peter Waterfield.. I 43

Henry Whiting .......... 800

Madm. Whiting .......... 950

Jno. Goodson .......... I 50

Wm. Morris ........... 350

Mary Lassells .......... 200

Peter Ransone .......... 220

Charles Waters ......... 200

Dorothy Kertch ........ 220

Dorothy Boswell ......... I600

Richd. Cretendon ........ 280

Elizb. Anniers ......... 250

Elizb. Snelling ......... 250

Joseph Boswell .......... 230

John Bullard ........... I00

Anthony Elliot .......... 100

Wm. Armistead ........... 100

Peter Kemp ........... 650

Majr. Peter Beverley ..... 800

Ditto per Tillids Lands .... I50

Dudley Jolley ............ IO

Robt. Couch ........... 100

31603

Glocester Rent Roll

A Rent Roll of Abbington Parish

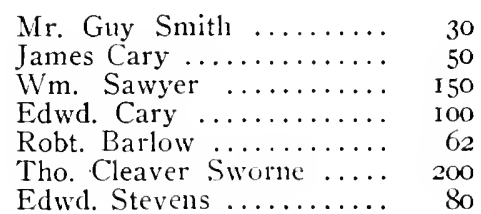

Henry Stevens ......... Co

Chillion White .......... I00

Jerimah Holt .......... 350 of Ditto for the Widdo Babl 150 Robt. Yarbborrow ...... I00 Robt. Starkey .......... I00 Henry Seaton ........... 170 
Hugh Howard ......... 200

Capt. Booker .......... I000

Jno. Stoakes .......... 300

Jno. Dobson ........... 400

Wm. Dobson .......... 950

Edmd. Dolsson ......... 350

Hugh Allen ........... 1250

George Jackson .......... II

Jno. Teagle ........... 30

Widdo Jones ........... 45

Mary Thomas .......... 100

Thomas Seawell ........ 200

Benj. Lane ........... 50

Valentine Lane .......... \&o

Jeffry Garves ........... 33

Thomas Coleman ........ 250

Johanna Austin ......... 40

Majr. Burwell ......... 3300

Jno. Satterwight ....... 50

Jerimiah Holt Junr. ..... 150

Charles Stevens ......... 75

Richd. Roberts for wife... 300

Jno. Sadler .............. 125

James Steavens .......... ro

Susamnah Stubbs ........ 300

Richd. Foster ............ 150

Henry Mitchell ......... 50

Nathanll. Russell ....... 550

Elizb. Richardson ....... 500

IVm. Camp ............. 175

James Row .......... 300

John Butler ............ IOO

John Smith Esqr. ....... 2000

Ditto for Robt. Byron.... 400

Capt. Blackbourne ....... $55^{\circ}$
Peter Richeson $\ldots \ldots \ldots \ldots$ 250

Penja Clements ........ 500

Thomas Graves ........ 70

Rolt. Page ............ 75

Joseph More .......... I50

Richard Dixon ......... 200

Elizb. Turner .......... I50

Owen Grathmee ....... 250

Richd. Woodfolk ....... I 25

Jno. Waters ...........

IVm. Hilliard .......... 80

Richd. Heywood ........ 100

Mary Hemingway $\ldots \ldots \ldots$ I 50

Wm. Kemp ........... 75

Robt. Francis .......... IO

Joshua Broadbent ........ 200

Joseph Coleman ........ 200

Grustam Clent .......... 100

Philip Grady .......... 150

Jno. Hall ............. 125

Tho. Walker .......... 300

Jno. Mixon ............. 400

Tho. !Sanders .......... 450

Wm. Smith for Kittson ... 50

John Banister ........... 2750

Madm. Mary Page ...... 3000

Jno. Lewis Esq. ......... 2000

Richd. Cordell

28426

Ware ....... 31603

Petso ........ +1123

Kingston $\ldots .+46537$

I. -176098

A Perfect Role of the Land in Middlesex County Anno Dom. I704

Richard Atwood ......... 100

Richard Allin ........... I50

Tho. Blew ford ........... I00

Mrs. Blaiss ............ 300

John Bristow ........... I40

Robt. Blackley ........... I00

Coll Corbin ............ 2250

Coll Carter ............. 1150

John Cheedle ........... 50

WWm. Carter ............... 170

Viddo Chaney ............ 800

Nath. Cranke ........... 50

Tho. Dyatt ............ 200

John Davie ........... 75
Wm. Daniell ........... I50

Robt. Daniell ............ 225

Henry Freeman ......... 200

John Goodrich .......... 50

Geo. Goodloe ........... 50

Geo Guest .............. 50

Richd Gabriell .......... 30

Wm. Finley ........... 50

$11 \mathrm{~m}$. Gardner ........... I00

Robt. George .............. I8o

David George ........... I50

Widdo. Hazellwodd ...... 200

John Hoare ............ In

Richd. Reynolds ........ 50 
Jno. Southerne .......... 100

Richd. Shurly ........... 200

-Tho. Hapleton $\therefore$...... 200

Vm. Southworth ........ 50

$\mathrm{V} \mathrm{m}$. Jones $\ldots \ldots \ldots \ldots \ldots .300$

Evan Jones ........... 50

Esqr. Wormley Estate .... 5200

Wm Churchhill .......... 1950

Jacob Briston ........... I00

Jno. Pace ............. 200

John Logie ............ 300

John Price ............ 519

Henry Perrott ........... 1100

Richd Kemp ............ I I 100

Tho Kidd ............. 250

Francis Weeks .......... 225

Widdo Wceks ........... 225

Henry Webb ........... I0

Tho Wood ............

Robt. Williamson ....... 200

Tho Lee .............. 100

Edmd. Mickleburrough ....

Valentine Mayo ...........

W'm. Mountague .........

Garrett Minor ............

Marvill Mosscley ..........

Joseph Mitcham .........

Minie Minor .............

Humphrey Jones ..........

Jno. North ..............

Henry Tugill ............

Henry Thacker ...........

Thomas Tozelcy .........

Charles Moderas .........

IVm. Mullins ..............

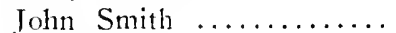

James Smith .............

Harry Beverley ...........

George Wortham ..........

Capt. Grimes .............

Sarah Mickleborough .....

Christo. Robinson .........

John Vibson ..............

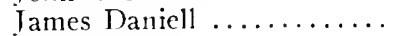

James Curtis .............

Tho. Cranke .............

Phil. Calvert .............

John Hipkins ...........
Richd. Daniell ............

210

Geo. Blake ............ I00

Edwd Williams .......... I00

Pat Mammon ........... I00

Alexander Murray ....... 250

Poplar Smith .......... 550

Olixer Seager ........... 380

Edwd Gobbec ........... 90

Henry Barnes .......... 200

John Davis ............ 100

Paul Thilman ............ 300

Hugh Watts ........... 80

Edwd Clark ............ 300

Charles Williams ........ I00

Edwin Thacker Estate ..... 2500

Thomas Dudly .......... 200

Thomas Mackhan ....... 200

Richd. Paffitt ............ 200

Tho. Hiff ............. 100

Peter Bromell ............ 100

Tho Blakey ............. 100

John Robinson ........... I, 350

Roger Jones ............ 100

John Nicholls ........... 200

George Berwick ........ I00

Widdo Hurford ........ 50

Widdo Hackney ......... 300

$1 \mathrm{Wm}$. Kilbce ........... 600

Ezikiah Rhodes ......... 300

John Handiford .......... I0

John Miller ............ 200

IV'm. Scarhorow ......... 200

II'm. Herne ...........

Rolit. Dudley ........... 300

Widdo Mason ............ 100

Peter Chilton ........... Ino

Francis Dobson .......... 150

James Dudley ........... 200

Capt. Berkley ........... 750

$1 \mathrm{~m}$. Sutton ............ 150

Sr. W'm. Skipwitl ...... 350

Coll Kemp ............. 900

Wm. Barbee ............ I50

Wm. Wallis ........... 300

Adam Curtin ............ 200

Capt. $1 \mathrm{~lm}$ Armistead ...... 2325

49008 
A True \& Perfect Kent Roll of all the Lands held in Essex County this present year 1704

Albott Wm............ 150

Andrews Geo ........... 200

Adcock Edwd ........... 230

Adeock Henry .......... 250

Acres James ............ 100

Arving $11 \mathrm{~m}, \ldots \ldots \ldots \ldots . .100$

Allin Erasmus .......... 100

Allin Wm............... 100

Arres Wm, ............. 200

Acres Wm. ............ 200

Banlwar Jancs ......... 800

Bendall John ........... 135

Butler John ........... I 25

Bowers Arthur .......... 600

Baulwar James ......... 200

Beesley Wm............ Iо.

Barron Andrew .......... 50

Bartlett Tho............ I00

Brown Buskinglian ...... 400

Beeswell Robt........... $\quad 100$

Beeswell Robt. Junr. ..... I50

Brown W. W........... t20

Brown Charles ............ I000

Buckner Richd. .......... I 200

Buckner Tho. ............ 1000

Brice Henry ............ 400

Bourn Jno. ............. 100

Beverly Harry ........... 1000

Pattail John ............. 1100

Baulwar Jolın .......... so

Rooth WViddo ............ son

Butler Jno. ............ 100

Butcher Jno. ........... 150

Bendrey IViddo ........ 700

Bird Viddo ........... 100

Beckham Symon ........ I00

Brutnall Richd ........... I00

Brook Robt. .......... 400

Ball Jno. .............. I50

Brooks James .......... 100

Billington Mary ........ 200

Brooks Peter .......... 275

Bowman Peter ......... 400

Brooks Robt. .......... 150

Brasur Jno. ........... 300

Brush Richd. .......... 250

Baker Henry ........... 350
Bradburn Richd. ........ I00

Brown Francis ......... 150

Brown Danll. Junr. ...... 150

Bryom Henry ........... 100

Burnett Tho. Junr. ....... I000

Baughan James Senr. .... 600

Baughan James ........ 150

Baughan Henry ........ I00

Brown Danll. Senr. ..... 450

Brown Tho. ........... 50

Blackiston Argail ........ 200

Burnett John ........... 365

Burnett Tho. Junr. ..... I30

Bailer Jno. ........... Soo

Brakins Qrtr. .......... 250

Bell Thomas .......... 100

Condute Nathil.

Condute Nathl1. .......... 20

Cary Hugh ............ 50

Connoly Edwd. ......... 200

Cogwell Fredirick ....... 250

Copland Nicho. ......... 300

Cattlett Jno. ........... I 800

Covengton Richd. ......... 1000

Cook John ............ 112

Chew Larkin ........... 300

Crow Tho............. 300

Covington $\mathrm{Wm} . \ldots \ldots \ldots \ldots, 400$

Cheney John .......... 200

Cole IVm. ............ 200

Cheney Wm. .......... 700

Corbin Tho. Qr ....... 4 40

Cockin Tho. .......... 120

Coates Samll .......... 300

Cooper Richd. .......... I00

Cooper Tho. ............. I00

Copland Jno. .......... 175

Crow Jno. ........... 440

Chew Larkin ........... 550

Cooper VWm. .......... 50

Compton Wm. .......... 50

Cox Wm. ............. 500

Callaway Jos. ........... 87

Coleman Robt. ......... 450

Cobnall Symon .......... $\quad 100$

Chamberlain Leond. ..... 350

9764 
Daniell James .......... I00

Devillard Jacob .......... 80

David Tho. ............ I50

Dudding Andrew ....... 230

Davis Evans ........... I50

Dobbins Danll. .......... 550

Dressall Timo. .........

Daughty John11 ........ 200

Dyer Wm. ............. IOO

Daingerfield Jno. ....... 270

Daingerfield $W \mathrm{~m} . . . \ldots \ldots \ldots .270$

Dumin Wm. ........... 220

Dyer Jeffrey .......... IOO

Day Richd. ............ I00

Dicks Thomas ......... 500

I2959

Evans Rice ............ 200

Edmondson James ....... 500

Elliott Alice ........... 75

Evitt Tho. ........... I00

Emondson Tho.......... 700

Flowers, Isaac .......... 250

Faulkıer Nicho. ......... I00

Farrell Charles ......... 50

Franklin Nicho. ........ I I30

Foster Robt. ........... 200

Foster Jno. ........... 200

Fisher Jonathan ......... 250

Fisher Benja. ......... I50

Frank Tho. ........... 175

Fullerton James ........ 400

Fossett Wm............. I00

Ferguson Jno. ......... 150

Faulkner Edwd. ......... 530

17219

Green George ......... 300

Gray Abner ........... 350

Goulding $\mathrm{Wm} . . \ldots \ldots \ldots . \quad 200$

Gannock Wm. ........... 2100

Gaines Barnerd ......... 450

Griffin Tho. ........... 200

Gibson Jonathan ........ 700

Grigson Tho. ........... 300

Gouldman Francis ...... 300

Goulding John ......... 200

Goulding Edwd. ........ 380

Good Richd. ........... 200

Garnett John ........... I50

Glover John ............ ICO

Hawkins John ........... 1066
Hinshaw Samll. ........ 200

Hutson Tho. ............ I00

Harrison James ........ 400

Harrison Andrew ........ 300

Hilliard Thomas ......... I00

Harper Wm. ........... 240

Harmon Henry ......... 75

Hoult Richd. ........... I00

Humphrie Joc ........... I0

Hail Jno. ............. 900

Harper John ........... 748

Harper Tho. ........... 350

Hould David ............ $\quad 100$

Hudson Wm. ........... I00

Hinds Thomas ......... 100

Howerton Thomas ...... I75

Hodges Arth .......... 100

Hows Qrtr ............ 300

Harwood Peter .......... I25

Harway Tho. ........... I000

Hudson Tho. ........... 50

Hudson Wm. ......... 300

Hill Leond. ............ 300

Harwat Sanll. ........ 300

Jamison David .......... 250

Jones $1 \mathrm{Wm} . . \ldots \ldots \ldots \ldots$ I65

Jenkins David ........... 50

Jewell Tho. ............ I00

Johnson Widdo. ......... 300

Jones Walter ........... I00

Johnson Richd. .......... 50

Johnson Wm. .......... 650

Jones John ........... 300

Jones Richd. ........... 350

Jenkins John .......... 93

Jones Wm. ........... 300

Journey Wm. .......... 243

Johnson Thomas ....... 500

Jones Rice ............ 500

Key Robt. ............ 209

Kerby Henry ........... 60

Landrum John ........... 300

Landrum James ......... 100

Long Richd. .......... 300

Lomax John ........... 2000

Loyd George ........... 800

Lawson Claudy ......... 100

Little Abrahan .......... 60

Lacy John ............. 100

Law John ............ 300

Lattaine Lewis ......... 250

Leveritt Robt. ........... IOO

Micou Paul ........... 150 
Martin John ........... 400

Morgain John .......... 100

Míller John ........... 150

Medor Tho. ............ 300

Moseley Benja. .......... I IoO

Mottley John ........... 100

Morris John ............ 200

Moss Robt. .............. I

Merritt Tho............ I 24

Merritt Joln ........... 100

Munday Tho. ........... 500

Magcon David .......... too

Mice Hno. ............ 200

Mosseley Robt. .......... I00

Mayfield Robt. .......... 100

Matthews Richd. ........ 250

Moseley Edwd. ......... 550

Merriweather Francis .... 3200

Mefflin Zach ............ $\quad 400$

Michacll Jno. ........... 200

Merriweather Tho........ 2 100

Mefflin Lath ............ 400

Medor John ........... I00

Morse John ............ 400

Matthews Benja. ........ 200

Mountegue Wm......... 850

Newbury Nathll. ........ 200

Nixson Henry .......... 500

North $\mathrm{Wm}$............. 900

Newton Nicho........... I00

Nightingall John ........ 100

Osman James .......... 300

Presser John ........... 450

Poe Samll. ............ 800

Pley Widdo. .......... 800

Parker J $110 . . \ldots \ldots \ldots \ldots .250$

Pitts Jon. ............ 200

Piskell Jno. ............ 300

Pain Jno. ............ I35

Price Wm. ............ 100

Peteras Tho. ........... 200

Powell Honor .......... 72

Powell Wm............ 72

Powell Place $. . \ldots \ldots \ldots \ldots . \quad 72$

Powell Tho............ 72

Payne Widdow .......... 1000

Perkin Henry ......... 300

Prichett Roger ......... $\quad 167$

Paggett Edmd. ......... 700

Price John ............. 1100

Pickett Johnı ........... 800

Perry Samll. ........... 225

Price Wm. ........... 100
Quarter Xtpher Robinson.. 2200

Quartr Tho. Corbin ...... 4000

Qrtr Rolit. Thomas ...... 200

Quartr John Hay ........ 1000

Quartr. Wm. Smith ...... 3000

Quartr Gawen Corbin ..... 2000

Quartr Peter Ransom .... 300

Quartr David Gwin ....... 950

Quartr $1 \mathrm{Wm}$. Upshaw .... I000

Quartr Leversons ........ 600

Quartr Tho Todd ........ 550

Ridgrdall John ........... 300

Ramsey Tho. .......... 550

Rowze Ralph ........... 6ro

Rucker Peter .......... $\quad 500$

Rowze Edwd. .......... 300

Royston John ......... I000

Roberts Edmd. ........ 300

Rebs Henry ........... 400

Reeves Joseph .......... 200

Reeves James .......... 200

Roberts John .......... 50

Richardson Robt. ....... 200

Reynolds James Senr. .... 500

Reynolds James ........ 500

Ransom Peter ......... 1200

Strange Jno. ........... I00

Stepp Abra. .......... 390

Samil. Antho. ......... 300

Sail Cornelius .......... 73

Salmon John .......... 60

Spiers Jno. ........... 160

Smith Wm............. 150

Stokes Richd. .......... 500

Smith Charles .......... 3000

Sullenger Peter ......... 400

Sales Widdo ............ II50

Shipley Jno. ............ 200

Spearman Job ......... 300

Smitl Francis ......... 500

Stallard Samll.. .......... 100

Ship Jos .............. 350

Short Tho. ............

Scott Wm. ............ I I 100

Stogell Jno. .......... 100

Stephens Jno. ...........

Slaughter Phebe ........ 352

Smith Jno. ........... 75

Smith Jonas ............ I00

Sanders John ........... 300

Stanton Jno. ........... 95

Shepherd Jeremial ...... 300

Smith Tho. ........... 50 
Shackelford Francis ..... 300

Sthrasliley Tho ......... 200

Staners Tho .......... 500

Snead Tho ............ 950

Shackelford Henry ...... 50

Thorp Widdo ......... 400

Tinsley Tho. .......... II I

Thacker Samll. ........ I Io

Tomlin Widdo ........ 400

Taliaferro Francis ....... I300

Thornton Fran. .......

Tomlin Wm. .......... I600

Thomas John ......... I00

Taliaferro Cliarles ..... 300

Thomas Wm. ......... 200

Taliaferro John ........ 2000

Turner George ......... 200

Tomlin Wm. ......... 950

Trible Peter ........... IOO

Taylor Richd. ......... 6 650

Tilley Matthew ........ 200

Vanters Bartho ......... 400

Virget Job .......... 50

Vincent Vaus ......... $\$ 50$

Wakeland Wn.......... Ion

Wood Tho. ............ 50

Winslow Tho. ........ I50

Winslow Heury ........ 100

Williams Jolnn ......... 450

Williams Wm. .........

Wilson David ......... 50

Wilton Richd. ......... I50

Wheeden Edwd. .......

Ward Widdo. ........... 200

Whitehorn Widdo. ...... 260

Wms. Emanuell ........ 100

Watkins Thomas ....... 400

Waters John ......... I50

Webb James .......... 200

Webb John ............ 200

Wead Wm............ 200

Wood Tho ........... 300

Williamson Tho ....... 100

Williamson $1 \mathrm{~km}, \ldots \ldots \ldots \ldots$ ICO

Williamson John ....... ICO
Webb Robert ......... 375

Webb Isaac ........... 200

Woodnatt Henry ....... 300

Waginer John .......... 400

Ward Geo. ........... 350

Wheeler Tho ......... 250

Young Wn1. ........... I000

Young Giles ............ 100

Museoe Salvator ....... roo

Moody John ........... I I50

Maguffe Joln1 .......... I00

Brookins Quartr. ....... 250

Simith Jno. Quarty ....... I000

Newton Henry ......... 100

Newton Henry .......... 175

Nowell Dall ...........

Nowell Widdo ......... 300

Garrett Tho ........... 1000

Gould Price ........... 200

Green Sannll. ......... 97

Gouldman Frant. ....... 300

Gawdin Wun......... Ioo

Grimmall Wn. ........ I00

Gaitwond John ........ 100

Games John ........... 475

Samll. Thompson ....... I000

$\overline{140580}$

Lands held in the ahove said Connty the Rents not paid and lield by the severall Gentlement as followth vizt.

John Smith Esqr. of Glocester Connty ......... 800

Wur. Buckner of Glocester by information ........

J110. Lightfoot Esqr. New Kent County .........

Jno. Bridgate in Engld. ....

Richd. Wyatt \& Jno. Pettus

of King \& Queen Cty. ... Eoo

Wm. Berry of Richmond County $\ldots \ldots \ldots \ldots \ldots$

1500

900

700

400

Richard Covington

\section{Accomack Rent Roll}

A

Alexander Richards ...... I50

Artlur Upshot ........... 2020

Antho. West $\ldots . \ldots \ldots \ldots$. 700
Ann Simkins ........... 1000

Arthur Donas ........... I00

Arnoll Harrison ......... 630

Alex. Harrison...... .400 
Mex. Bagwell ......... 4I3

Anne Chase ............ 200

Arthur Frame ........... 500

Mexdr Vest ........... 550

Abraham Lambedson ..... ion

Alex Benstone .......... 270

Anne Blake Widdo ...... 120

Amne Bruxe ............ I

Ar. Arcade Welburn .... 185t

$018 ;$

\section{B}

Burncll Niblett ......... 100

Majr. Bennit Scarbrotgh .. $\frac{521}{621}$

\section{C}

Corneline llermon ....... $32 \mathrm{I}$

Christo Stokly ......... 200

Charles Scarbrough ...... I000

Charles Leatherhery ...... I 100

Charles Bally ........... 959

Charles Pywell ......... 150

Churchliil Darly ........ I25

Charles Evill .......... 550

Charles Champison ...... 270

Christo Hodey ........... 500

Cornclius Lofton ......... in

Char!es Stockley ......... I

Charles Taylor ......... 580

Catherine Giand ........ 217

$6312 \%$

\section{()}

Dorman Derby ........ 225

Daniell Derlyy Senr. ..... 300

Dorothy Littichouse ..... 250

David Watson .......... 200

Delight Shicld ......... 300

Daniel Derhy Junr ....... 125

Daniel Harwoor ........ Jo

Demis Mores ........... 200

Danicl Gore ........... $397^{6}$

561,6

E:

Coll Folud Searbromell .. zono

Elwd llitchins ......... I70

Edwd Turner ............ 750
Edwd Killam ........... 720

Edmd Allin .................

Edwd Bagwell for Coll Wm. Custis ................

Edind. Jones ............

Elizb. Tinley ..............

Edwd Taylor .............

Erlmd Tatham ............

Edmd Bally ...............

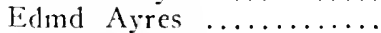

Edwd. Miles .............

Elizb. Mellchop ...........

Edwd. Bell ..................

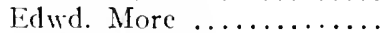

Edwd. Gunter ...............

Edwd Brotherton ..........

Elias Blake .............

Edwd Robins ................

Edwd Bally ..............

Elias Taylor ............ I 500

Elizb. Wharton .......... 200

Mrs. Elizb Scarbrough.... 4205

I 7 I 8 I

F

Mr. Francis Mackenuy .... 5109

Francis Rolts. .......... 200

Francis Wainhouse ....... 700

Francis Crofton ........ 200

Francis Young ...........

Finley Macklim ......... Ion

Francis Ayres ........... 300

Francis Jester ......... 200

Francis Benstonc ........ 400

Francis Wharton ......... 600

7909

\section{G}

Geo. Anthony ........... I0

Geo. Hastup ............. 300

Coll rico Nicho llalk ..... 2700

Capt. Geo Parker ........ 2609

Gervis Baggally .......... 700

Garrat Hictlims ......... 170

Geo Parker Sco. Side..... I200

Griffin Savage ........... 650

(ien Middleten Senr ....... 5is

Geo Trevit ............ 4 40

(ico. Ponnce ........... 400

Geo Middleton Inur .......

Geo Johnson ........... 200 
Capt. Geo Hope

noo

I 1057

\author{
$\mathrm{H}$
}

Henry Armtrading ....... 175

Henry Chance ........... 445

Henry Selman .......... I80

Henry Ubankes .......... 400

Henry Lurton ........... 363

Henry Stokes ........... 208

Henry Custis ........... 774

Henry Bagwell ........... 412

Henry Read ........... 350

Henry Ayres .......... 250

Hill Drummond ........ $4 \$ 3$

Henry Toules .......... 300

Henry Hickman ......... I.35

Henry Gibbins ......... 250

Henry Truett...$\ldots \ldots \ldots .240$

4965

John Tounson I

Joseph Stokley ................

Ino. Read ................

Ino. Blake .............

Joseph Ames .............

Joseph Clark ............

Jno. Fisher .............

James Gray .............

Ino. Huffington ............

Jno. Legatt ..............

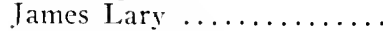

James Longoc ...........

Ino. Merrey .................

Ino Milloy .............

Jno. Pratt $\ldots \ldots \ldots \ldots \ldots \ldots$

Jno. Revell ..............

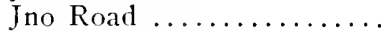

Jno. Rowles .............

Ino. Savage Senr ...........

Ino Charles ................

Ino Villis Senr ..........

Ino Willis Junr ..............

James Fairfax ..............

Joseph Nilly ..............

John West Junt .........

Ino Jenkins .............

Jonathan lames ..........

John Rodgers ............

Jno Collins
Jno Sincocke ............ and Samll. Metcalfe .... Joseph Touser .............

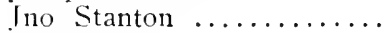
Jno Bally .........................

13715

Ino Melson ........... Iso

Ino Bernes Senr ......... 65

Ino Littletone .......... 200

John Nock ........... 300

Ino Killy .............. I00

Jacob Morris ........... 200

Jno Morris .............. $6_{40}$

Jona. Aylworth ......... 200

James Davis ............ I000

Ino Parkes ............. 200

Ino Evans ............. 200

Ino Hull ............. 100

Ino Blockson .......... 700

Ino Abbott ............. II 70

Ino Arew .............. 234

Ino Grey ............. II

Ino Baker ............. 400

Jno Wharton ........... I50

James Taylor ........... I00

Jno Glading ............. 207

Ino Loftland ........... 167

Tames Smith ........... 756

Majr Jno Robins ....... 2700

Ino Collins for Asban...... 1656

Tames Walker .......... 525

Ino Whelton ...........

Ino Marshall ........... I6 666

Jona Owen ............ 230

Jacob Wagaman ........ I50

Capt Joln Broadhurst ..... I I 100

Ino Dyer ............ 200

Mr. Tohn Watts ........ 24.50

Jno Booth ............ 300

John Bradford ......... 364

Ingold Colb .............

mo Griffin ............. 150

Jno Mitchell ............. 400

Joln Parker ............ 970

James Alexander ........ 1250

Jno Burocke ........... 200

James Sterferar ......... 50

Tno Perry ............ 217

Tno Drummond ........... 1550

Jno Carter on Foxs Island 203

oo

25

(1)


Juo Warington $\ldots \ldots \ldots \ldots$ I00

Ino Bagwell .......... 465

Ino Wise Senr .......... 800

Ino Wise Junr .......... 400

Ino $\operatorname{Dix} \ldots \ldots \ldots \ldots \ldots .6500$

Isaac Dix ........... 500

Ino Hickman .......... 454

Jno Onians ........... 200

Coll Ino Custis Esqr...... 59:0

John Coslin ........... 50

$\overline{46692}$

\section{M}

Nichaell Recetts ......... 3no

Mrs. Mattilda West ...... 3600

Marke Evell ........... 250

Mary Wright .......... 200

4350

\section{$\mathrm{N}$}

Nicholas Mcllchops ...... 285

Nathaniel Williams ....... 64

Nathaniell Rattcliff ..... 300

649

\section{$\mathrm{O}$}

Owen Collonell ......... 500

Overton Mackivilliams .... 200

Obedience Pettman ....... II 5

815

\section{$\mathrm{P}$}

Peter Major ............ 113

Pliilip Parker ........... 150

Peter Rogers .......... I67

Perry I.eatherbury ....... 1750

Peter Turlington ........ 79

Peter Ease ............ 250

Philip Fisher .......... 4.33

Peter Chawell .......... 250

3192

\section{$\mathrm{R}$}

Rolt. Bell ............ 650

Richd Bally Scur. ........ 2 too

Richel Bally Junr ........ I80

Richd Garrison .......... 468
Roules Major ......... 157

Rouland Savage Scnr ..... 950

Robt. Taylor ........... 95

Richd. Rodgers ........ 450

Richd Killam ........... I900

Robt. Wattson .......... 425

Richd Jones .......... 500

Robt. Hutchinson ....... 934

Reynold Badger ........ 150

Robt. West ........... 400

Riclsd Cuttler .......... 450

Robt. Cole ............ I25

Richd Drummond ........ 600

Robt. Stocomb ........ 300

Robt Norton ........... 1050

Richd Grindall ......... 350

Roger Hickman ......... I 35

Robt Lewis ........... 200

Roger Abbott .......... 450

Richard Hill .......... 350

Ralph Justice .......... 1050

Richd Hinman ............ I800

Robt Davis ............ $\mathbf{3}_{4}^{\mathbb{R}_{4}}$

Ragnall Aryes ......... 300

Roger Miles ........... 200

Richd Bundike .......... 773

Richd Kittson ......... I300

Robt. Bally ........... 100

Richd Starlin .......... I50

Richd Flowers .......... 200

Richd Price ........... I0

Robt. Pitts ........... 2300

Robt Adkins .......... 200

Rebeckha Benstone ....... 270

Richd Hillayres ........ 300

22816

\section{$\mathrm{S}$}

Samuell Benstone ....... 300

Sarah Beach .......... 300

Sillvanus Cole .......... 250

Symon Sosque .......... 325

South Littleton Widdlo .... 2870

Steplien Woltham ....... 244

Stcph. Warrington ....... 400

Symon Mitchell ......... 300

Stephen Drummond ...... 300

Selby Harrison ......... 50

Sollomon Evell ......... I25

Samll Young .......... 50

Sarah Reyley ........... I50

Sebastian Dellistations Senr 500 
Sebastian Dellistations Junr Skinner Wollope .......... Samll. Sandford ........... Sebastian Silverthorn ..... Symon Smith ............ Sarah Coe...$\ldots \ldots \ldots \ldots$. Samll Taylor .............. Sarah Evins .............. Sebastian Croper ......... Samuell Jester ............ $\mathrm{T}$

\begin{tabular}{|c|c|c|}
\hline Tho & Burton & 600 \\
\hline Tho & Bud ... & \\
\hline Tho & Boules & 300 \\
\hline Tho & $\ldots \ldots \ldots$ & 100 \\
\hline Tho & Middleton .. & 350 \\
\hline Tho & Stringer .... & 600 \\
\hline Tho & Haule ... & 500 \\
\hline Tho & Taylor .... & 100 \\
\hline Tho & Fockes .. & \\
\hline Tho & Bagwell $\ldots \ldots \ldots \ldots$. . & 465 \\
\hline Mad & m Tabitha Hill ....... & 3600 \\
\hline Tho & Rose $\ldots \ldots \ldots \ldots \ldots$ & 7 \\
\hline Tho & Webb............. & 50 \\
\hline Tho & Savage.......... & 450 \\
\hline Tho & Jones $\ldots \ldots \ldots \ldots \ldots$ & 100 \\
\hline Tho & Scott $\ldots \ldots \ldots \ldots \ldots$ & 100 \\
\hline Tho & Reyley $\ldots \ldots \ldots \ldots$. & 225 \\
\hline Thio & Ternall .............. & 150 \\
\hline Tho & Simpson $\ldots \ldots \ldots \ldots$ & 520 \\
\hline Tho & Coper $\ldots \ldots \ldots \ldots \ldots$ & 711 \\
\hline Tho & Miles $\ldots \ldots \ldots \ldots \ldots \ldots$ & 202 \\
\hline Thor & nas Bonwell .......... & 300 \\
\hline Tho & Bell Senr. ........... & 100 \\
\hline The & Bell Junr ............ & 100 \\
\hline Tho & Touson Kiquotan ..... & 800 \\
\hline Tho & Stockley $\ldots \ldots \ldots \ldots \ldots$ & 363 \\
\hline Tho & Jester $\ldots \ldots \ldots \ldots \ldots$ & 100 \\
\hline Tho & Smith .... & 300 \\
\hline Thor & nas Crippin & 648 \\
\hline Tho & Wilkinson..$\ldots \ldots \ldots$ & 50 \\
\hline Tho & Jenkinson $\ldots \ldots \ldots \ldots$ & 374 \\
\hline Tho & Moore $\ldots \ldots \ldots \ldots \ldots$. & I66 \\
\hline Tho & Allen $\ldots \ldots \ldots \ldots \ldots$ & 700 \\
\hline Tho & Smith Savannah ...... & 200 \\
\hline Tho & Perry $\ldots \ldots \ldots \ldots \ldots$. & 232 \\
\hline Tho & Tonnson $\ldots \ldots \ldots \ldots$ & 400 \\
\hline Tho & Smith Gingateague ... & 693 \\
\hline & t Coll Robinson ........ & 600 \\
\hline
\end{tabular}

WV

Wm. Robins .......... 200

Wm Patterson ........... 200

$1 \mathrm{Vm}$ Bevens ............. 400

Wm Matthews ......... 400

$\mathrm{Wm}$ Shepherd .......... 200

Wm Whett ........... 400

Winfred Woodland ....... 333

$\mathrm{Wm}$ Andrews ........... 300

Wm Custis ............ 1500

Wm Darby ............. 83

IV'm Fletcher ........... 200

II'm Killam ............ 450

I'm Lingoe ............ 300

IIm Major ............ 130

$\mathrm{Wm}$ Meeres ............ I50

W'm Mack Sear ......... 800

IVm Savage $\ldots \ldots \ldots \ldots \ldots$ I 50

$\mathrm{II} \mathrm{m}$ Vaite ............. I IO

Wm Sill ............. 200

IVm Waite Junr ........ 600

Wm Bradford ........... 3500

W'm Rogers ............ 200

$\mathrm{V} \mathrm{m}$ Wise $\ldots \ldots \ldots \ldots \ldots .400$

I'm Finey ............ 800

$\mathrm{Wm}$ Consalvins .......... 100

Vm Phillips ............ 200

IIm Parker ............ 362

V'm Cole .............. 375

$\mathrm{Wm}$ Merill .............

$\mathrm{Wm}$ Johnson ........... 150

$\mathrm{Wm}$ Lewis ............. I50

Walter Hayes ........... I30

$\mathrm{Wm}$ Chance ............ $45^{\circ}$

$\mathrm{W}$ m Milby ............ 250

Wm Nicholson ......... 600

W'm Burton ............. 500

Wm Willett ............ 8442

$\mathrm{V} \mathrm{m}$ Hudson $\ldots \ldots \ldots \ldots \ldots . .270$

$\mathrm{Wm}$ Lewis ............ 300

$\mathrm{Wm}$ Young $\ldots \ldots \ldots \ldots \ldots \ldots$ I 44

W'm Liechfield ........... 154

$1 \mathrm{Wm}$ Bunting $\ldots \ldots \ldots \ldots \ldots$ I50

Wm Nock Junr ........... 400

$\mathrm{Wm}$ Lucas .............. 300

Mary Mellechop ............ 498

IVm Daniell ............ 200

IVm Silverthorn ......... I60

Wm Garman ............ 475

Wm White ............ 600

Wm Broadwater ......... 500

Wm Taylor ............ 100

W'm IVilliamson ......... 600

$\mathrm{W} \mathrm{m}$ Brittingham ........ 538 
Wm. Benstone Jun. ...... 270

Wm l)ickson for Mr. Littleton .............. 1050

W'm W'ale Senr ....... 225

W'm Taylor ............ I 400

Alded to this Rent Roll the following lands of which the Quit Rents may possibly be recovered tho the Owners live out of the Comntry Viz.

Jonas Jackson ............ Robt. Andrews ...........

Joseph Morris ...........

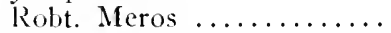

Ifillory Stringer ..........

Ino Fisher ........... I33

Timo Coe ............ 4100

Davil llagard $\ldots \ldots \ldots \ldots$ r. 130

68,6
An Account of what Land in Accomack County the owners whereof are not dwellers.

Tho Preson of Northamp-

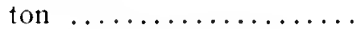

Geo Corbin Ditto ........ Joshua Fichett Ditto.....

Alexdr Mercy Maryld .....

Tho Dent ..............

Mr. Wm Kendalls orplians of Northampton County.

$\mathrm{Mr}$ Hancock Lee dividing Creeks .............. 4050

Richd Watters in Maryland Francis Lailor Northamp.. Obedience Johuson Qtrs... Henry Smith at the Southerd ................. Grattiance Michell North.. Matt. Tyson Southerd..... Teagle Woltham Maryld.. Peter Waltham New Engld Ino Wahthan Maryld.....

\section{Jno Wise Sheriff}

The Rent Roll of Northampton Comty for the Year of our Lord God I704

\section{A}

Andrews Robt. .......... 300

Andrews Andrew ........ I00

Addison John .......... 350

Abdell Tho ............ 125

Abdell Jno ............ 200

Abdell Wm ............. I 25

Alligood John ......... 300

Angell James ........... IoO

Alligood Henry ......... 100

$\mathrm{B}$

Bullock Geo ........... 100

Boner Gieo ............ I50

Brown Tho ............ Is6.2

Benthall Joseph Senr ...... 793

Benthall Joseph Jum ..... 150

Branson Francis ........

Bateson .............. 200

Billot Jno ............ f(o)

Bell Geo .............. $\$ 00$

Billott IV'm ............ IOn
Brewer Jno ............ 50

Blackson Juo ........... I00

Brooks Jeane .......... I00

Beadwine Jno .......... 200

Berthall Danll .......... 258

Baker John ............ too

Brickhouse Geo ........ 2100

\section{C}

Cob Samll ............. I, 30

Coape $V_{m} \ldots \ldots \ldots \ldots \ldots \ldots 200$

Custis Jno Coll .......... 3400

Collier Bartho........... 150

Carpenter Charles ...... 240

Cox Jno .............. 500

Church Samll .......... I43

Cleg Juo. Senr ......... 204

Clog Henry ........... 204

Carsy Richd ............ 100

Cowdry Josiah .......... I67

Cormeck Mich .......... 100

Clerk Jno ............ Ino 


\section{APPENDIX}

Corban Geo

$\$ 33$

Caple Nath ............ 100

Callinett Jno ............ ICO

Crew Jolnn ............ 300

Costin Francis .......... $\$ 75$

Custis Majr John ....... 3250

Custis Hancock .......... 50

Chick Tho. ........... I00

Downing Jno. ......... to

Dewy Geo ............. 300

Dewy Jacob ............. I00

Delby Margery ......... 450

Dowty Rowland ......... I50

Dunton John ........... I

Dunton Tho ............ 400

Dowman John .......... I00

Dullock John ............ 100

Denton Tho ............. 400

Dunton Tho Junr ........ I I 20

Dunton WWm ........... 120

Dunton Benj .......... 220

Duparks Tho ........... yo

Davis Jno .............. 850

Dunton Joseph ......... I $\quad$ I20

Dixon Michaell .......... ${ }_{460}$

$\mathrm{E}$

Eshon Jno ............. 600

Evans John ............ 200

Edinunds David ........ 500

Evans Tho ............ 300

Esdoll Geo ............. 100

Eyres Tho ............ II 33

Eyres Nich ........... 325

Eyres Capt Jno ......... 77.4

Eyres Anne Wide. ....... 733

Esdoll Edwd........... 100

F

Fisher John .............

Francisco Dan ............

Fisher Tho ..............

Foster Robt. .............

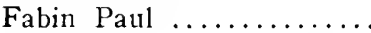

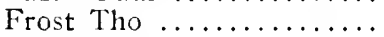

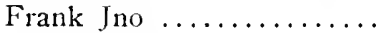

Floyd Charles .............

Freshwater Geo .........

Frizell Geo ...............

Freshwater $\mathbb{I V}_{\mathrm{m}} \ldots \ldots \ldots \ldots$. liitchet Joshua .......... lilogd Berry \& Matthew...

I(O)

555

G

Gogni Darid ........... I50

Gill Robt. ............ 200

(iascoyne Rolt. ........... I I 25

(iascoyne $\mathrm{Wm} \ldots \ldots \ldots \ldots .525$

Gircene Jno Senr ......... 2200

Giddens Tho .......... 227

Grice Peter .............. 200

Godwin Devorix .......... 100

Goffogan Tho ............ I00

Guelding Charles ........ 200

Griffith Jerimiah ........ 345

Griffith Benja ........... 200

\section{If}

Hill Franc:s ............ I00

Hendersun John .......... 250

Haggaman Isaac ........ 750

I Iarnionson Jno .......... I Geo

Harmonson Henry ....... 1250

Ifanby Charles ......... 25

Hanby Richd ........... 75

Hanby Danll .......... 50

Hanlyy John ...........

J farmonson Capt $V_{11} \ldots . .303$

Harmonson Geo ......... I 580

Harmonson Tho ......... too

I Hawkins Jno Senr ........ 66

Ilawkins Jno Junr ....... 66

Hawkins Gideon .......... 66

Hunto Groton ............ 485

Hunt John ............. tho

Ifunt Tho ............ 20

Hall Francis Widdo ..... 340

Jolnson John Senr ....... 250

Johnson Jolm Junr ......

Johnson Jacob ......... 350

Isaacs John Jnr ........ 100

Joynes Major ........... I50

James Joan Widdo ....... 250

Jolnson Obedience Capt ... too

Johnson Tho Junr ....... 75

Johnson Thomas Sent ... t60

Jackson Jonah \& Jolnn ... 625

Joynes Edind ........... 200

Joynes Edwd ............. 200

Johnson Jeptha Senr ..... 50 
Jacob Phillip Senr .......

Johnson Jepha Junr .......

Juhnson Ubedience \& Jepha

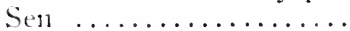
Johnsun Edmd .......... Jacob Richd ............ Jacob Abraham .........

K

Kentall $\mathrm{Wm}$........... 2410

Knight John .......... 100

\section{$\mathrm{L}$}

Lawrence John ...........

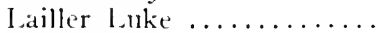
Lucas Tho .............. Lew is Rol, ............ Littleton Susamah Wido. Luke John ............

\section{$\mathrm{MI}$}

Marshall fieo $\ldots \ldots \ldots \ldots$. Farshatl fno .......... 250

Maddex Tho ........... I500

Michaell Jeardly ........ too

Matthews John ..........

Major John .............

Mal John ...............

Moore Mathew .........

Mackmellion Tho ........

More Gilbert .............

Morraine John ...........

More Jno ...............

More Eliner ................

\section{N}

Nicholson IVm ......... సottingham $\mathrm{Wm}$...........

Nottingham Joseph ......

Nottingham Richd .......

Nottingham Benja .......

Nelson John

\section{$\mathrm{O}$}

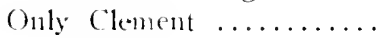
(okar John ..............

200 IOO

\section{$\mathrm{P}$}

Parramore Tho ........ 400 P'renon tho ............ 6ro Pencell Frances Widdo ... 1225 P'almer Samll ......... 1562
Pyke Henry ........... 150

Puwell Johin .......... 636\%

Pittett Tho ........... 300

Pittet Justian .......... 260

Pittett John .......... 275

Puwell Samll .......... 200

Paine Daniell .......... 150

Piggott Ralph .......... I368

\section{$\mathrm{K}$}

Read Thomas .......... I50

Rascow Arthur ......... Ino

Konan $\mathrm{IV}_{\mathrm{m}}$............. 150

Roberts Jno ........... 200

Richards Lettis ......... 150

Kohins Jno Majr ........ II8O

Rohins Littleton ......... 1000

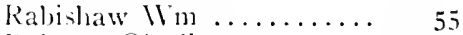

Koberts Obedience ....... 260

Rolinson Benjamin ..... 250

\section{S}

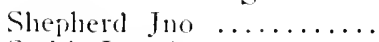

Smith Joseph .......... 250

Smith Samll ............ 150

smith Jno ............. 200

Savage Tho $\ldots \ldots \ldots \ldots \ldots$...... 450

Smith Tho ............ 400

Sulth Abrah ........... 300

Seady Antho ............ 120

Sott Widdo ............ 750

Simith Richd minor ...... 300

Scot Geo .............. 100

Smith Richd ........... 99

scot Jno ............. 100

Scott Henry .......... 800

Scot David ............. 300

Smith Peter ........... 450

Sanders Richd .......... I00

Smaro John ............. 800

Shepherd Tho .......... Ito

Sanders Eustick ......... I00

Sanderson John ........ 636

Savidge John .......... 410

Stringer Hillary ......... 1250

Savidge Capt Tho ........ 1600

Savidge Elkington ....... 750

Scot $1 \mathrm{Vm}$ Senr .......... ${ }_{153}$

Straton Benja .......... 745

Simith Geo ...........

Stockley Jno Senr ......... 370

Shepheard IViddo ...... 830

Seamore Joln .......... 200 
$\mathrm{T}$

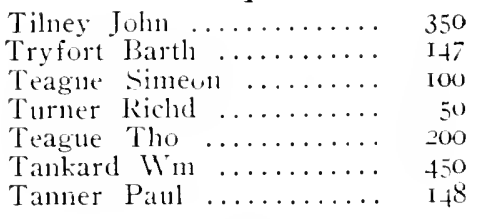

IV

Webb Henry ........... I00

Wills Thom ........... 300

White John ........... 400

Wilson Tho ........... 250

Westerhouse Adryan Sur. 200

Walker John ......... 300

Ward Tho ............ 120

Walter John ........... too

Waterfield Wm .......... 200

Warten John ........... 525

Warren Argoll ......... 350

Widgeon Roht .......... I00

Wilkins Ino $\ldots \ldots \ldots \ldots \ldots$ I 50

Webh Edwd ........... 200

Wilcock Jno ............ 200

Warren James .......... 50

Waterson Wm ........ 855
Warren Rol,t. .......... I90

Water lient-Coll $11 \mathrm{~m} \ldots$... 700

Vebl Charles .......... $133^{1}+$

Willett Wms .......... 2650

Waterson Richd ......... 150

Wilkins Argoll ......... 150

Walter Elizb Widde...... I00

Warren Joseph ......... 50

(9) $6 ; \mathrm{I}$

Lands not paid for rizt

Gleab formerly Capt Foxcrofts ............. I500

John Majr at Occahannock 200

Hoglin not being in Virginia Ico

Tho Smith ............ 300

Tho Marshall orphan .... 75

Jno Rews not in Virginia .. 100

The total on the other side is ............ 996, 1 acres

Added to it ye Glebe land $\ldots \ldots \ldots \ldots \ldots$...... 1500

101171 acres

The preceding Sheets are true conss of the Rentrolls for the year rof given in and accounted for by the several Sherifs in April 1705 and sworne to he fore his Excelley according to which they male up their accomts of the Quitrents with

Will Robertson Clerk. 

INDEX 



\section{INDEX}

Acosiac,

farm and tithables of, 58; 79

Allen, Arthur

six tithalles, 57

Allen, William.

Burgess in $1629,73$.

Allerton, Isaac,

deals in servant:, 48.

Ambrose, Rrotert.

deals in servants, 49 .

Anlury, Major,

describes Virginia unoer claso, 158

Andros, Sir Edmund,

$29 ; 35 ; 52$; hesitates to deprive $x$ edthy of lanrl holdinge, 143.144.

Archer, George

deals in servants, 49; extensive land. owner, is.

Armetraling, Henry, 79.

Artisans,

became planters in Virginia. 27: callow for in broadsite of 1610 , 28 ; on the plantations, $156 \cdot 157$.

Ashton, Peter,

deals in servants. 48

Austin, James. deals in servants. 48.

Avery, Richard, his cattle, 101; inventory of, 105.

$\mathrm{B}_{\text {s }}$ Cos, Nathaniel, Sr. $109: 110$.

Bacon, Nathaniel. Ir., deseribes prerty in Vinginia, $91:$ r bellion of and Maciration Acts, 92 93 says peoples hoved in Burgesses, 10\%; 113

Baker, Inhn,

buys Button's Rilge, 4\%.

Baldwin, William, landowner, 79

Ballard, Thomas, 109

Ball. William,

Baltic, has 22 slaves

English trade of, 8; Drnmark control: entrance to. 9; wars cndanger trato in, 9; cheap labor of. 16;17; tobace trade to, 118-119; trate to injuted by ata. 131. 148 .

Banister. Iohn, has 88 slaves, $15 \%$

Barhadnes.

complain of Nazigation Acts, 94.
Barnett, Thomas, ज.rvant, Burness in 1629,74

Bisefte, William, deals in servants, 48.

Berer, Gerorge I.endis, defends Varigation Acte 84.2": 57y trade restrictions did not cause Bacon's Rebellion, 92; statement of crncerning crounty grievances, 93 ; drenims that or irus oppoition existel to Narigation Acts, 93.34

Be:11, Richarr, landowning freedman, i4

Bennett, Richarrl, estate of described, 108

bernete, Samuel, landowning freedman, 74

lietheley. Jehn, conducts iron wrotk in Virginia 1.3.

Berieley, Lord John, gro.

Bertaley, Sir Willam, describes servants, 34; describes eariy mortality among servants, 33. fostimate servant - at $6,0,00$ in $16,71,41$; instructed to urohibit foteign trade, fo: permit foreign trale during Ciril War, 6, calls Virginia land of opportunity. 75 ; troelaims Charles II, 84, 111; 89; te. scribes poverty of Virginia, 90, 91,92. 23; controls Assembly, at; goes to Eng. land to combat Narigation Acts, 94.95 ; plans tre estaljlish manufactures, 95; denounce Naigation Act.s, 95.96; $33^{\circ}$ =ecure body guard. 111; electerl Gour. nor prior to Restration, 112; faras King's resentment, 113; small planter turn against in Bacon's Rebellion, 113 ; estimates slaves at 2,000 in 1670, 124 ; $125 ; 16,0$.

Bevarley, Robert, Sr., extensive dealer in servants, 48 , : 113.

Beveriey, Robert, It. 61; imports slaves, 139 ; describes frids of yon whites, 155

Pibbie. Erlmund, deals in servants, $\because 9$

Binns. Thomas. eight tithabies. 57.

Bishop, John. Burgess and landinner, 78

Blackintone. John, vatents land, it

Biand. John. remonsirates against Nazigation at $88-89 ; 93$. 
Blair, Rev, John, asks funds for collcge, 50, 136.

Blewit, Capt. sets up iron works in Virginia, dies, 181 .

Board of Trarle.

arrears of quit rents reported to, 51; Nicholson writes to concerning rent roll, 52 ; says servants not slaves, $60 ; B c r k c$. lcy protests to 95,119 ; asks reasons for emigration of Jirginia whites, 140 ; secks to limit size of land grants, 143; again alarmed at emigration from Vir. ginia, $145,147,157$.

lBolling, Mrs. Mary, has 51 slaves, 158 .

Brent, Giles, dcals in servants, 4S; 109; 113.

Bridger, Joseph. deals in servants, 48; 109.

Briggs, Gray, has +3 slaves, 158 .

British Empire, beginnings of misunderstond, 1t; begun, 19; important rôlc of tobacco in, 27.

Broadnat, John, 128.

Broarlside. in 1610 calls for settlers for Virginia, 28.

Browne, Robert. landowning freclman, 74 .

Browne, William, ninc tithables, 57

Bruce, I'lilip Alexander, deseribes small planters, 54.

Brunswick, land patents in small, 145

Bullock, William, denies that servants are slaves, 60 .

Burgesses.

54 , petition King, 65 ; complain of high freight rates, 72 ; frcedmen among, 73 . 75; Narigation Acts and, 94.95; repre sent interest of small planters, 109 ; defy the king, 110; petition of, 110 ; rule Vir ginia, 1652-1660, 112; growing influenee of, 109 .

Burwell, Francis, patents land in James City, 77.

Burwell, John, has +2 slaves, 158

Burwell, lewis, dcals in servants, 48; 109

Burcher, William. patents land, 79

Bushond, John, sclls laurl, 49.

Butt, 'Thomas, icals in servants, 48.

Rutton, Robert, reccives estate, 49

Buton, Thomas, owner of Butten's Ridyc, 49.

Byril, William 1. says rent rolls inaccurate, 52 ; 109 ; uses slaves, 130 .
Byrd. William II,

gives reasons for emigration to Carolina, 146.

C ARTER, John 109 .

Carter, Rohert. has 126 slaves, 153

(arleill, Capt. Christopher. urges trade with Amcrica, 11.

Carolina.

emigration to from Virginia, 99-100. $139-1+6$

Cattic plentiful in Virginia, 101.

Chambers. William, servants and slaves of, 59.

Chandler. John, landowning freedman, 74

Charles I. considers smoking harmful, 26; tries to limit tobacco planting in Virginia, 27 tries to limit English tobacco crop, 63; limits price of tobacco, 65 ; regulates tobacco trade, 67.69; 70; defied by $A s$. sembly, $110 ; 111$.

Charles II.

33 ; proclaimed in Virginia, $84 ; 111 ; 93$ 96; not restored in Virginia before Restoration in England, 112; tyranny of, 114.

Charles City,

Mlantations small. 53; 54; farms and tithables of, $58 ; 79 ; 81$.

Chastellux.

deseribes poor whites of Virginia, 152; notes indolence of poor whites, 155

Chew. Larkin, dealer in Spotsayliania land, 154.

Claiborne, William. deals in servants, 48

Clayton, Thomas, 80.

Clergy, many plant tobacco, 28 .

Clothing, want of felt in Virginia, 103.

Cloyse, Pettyplace. landowning freedman, 74

Cole, Edward. jatents land in James City, 77 .

Colonial expansion, sought as remedy for British economic depentence, 10; urged by economists, $11 ; 12 ; 13$.

Colonial system,

68 ; imperfectly cnforced prior to 1660 67.69 ; 85.86 ; cmbodied in Narination Acts, 85; colonics to supplement Eng. land, 86; workings of at end of $17 \mathrm{th}$ century, 120; British conception of, 136

Cimmerec.

of England with Baltic, 8; principles of long known. 11; of England with Europe and East, 12; of England with France declines, 13; affords hey to his. tory, 22; in reexported tobacco, 70 ; in 
tobacco revives after $1683,114-115$; in reěxported tobacco, 116-120; importance of in tobacco for England, 119, 122.

Commonwealth,

tobaceo high under, 66; Virginians trade abroad under, 69; 98; attitude of Virginia under, 110.11

Constable, John.

trades illegally, 69

Cooke, John, landowning freedman, 74 .

Cornell, Samuel, servants and slaves of, 59.

Council,

65 ; complains of high freight rates, 72 ;

90; deseribes poverty in Virginia, 91;

says Virginia ready to revolt to Duteh.

$96 ; 109 ; 110 ;$ members of hold land il

legally, 143; gives reasons for immigra-

tion out of Virginia, 145; describes

misery in Virginia, 150; declining influence of, 159.

Creighton, 'Henry,

sells 100 acres, 50 .

Criminals,

few sent to Virginia, 32,33 ; male no imprint on social fabrie, 33 .

Crocker, Wm.,

servants and slaves of, 59 .

Cromwell, Oliver, sends Irish servants to Virginia, 33.

Crump, Thomas, servant, Burgcss in 1632, 74; landonner. 75.

Culpener, Lord, fears ruin of Virginia, 91, 114.

Custis. John, 109.

Daingerfield, William. has 61 slaves, 157 .

Dawson, William, landowning frecdman, 74 .

Day, John, 80.

Delaware. manufactures of lure noor Virginia whites, 141; migration to, 139.146.

Delk. Roger, landowning freednan, 74 .

Dicks, John, purchases land, 49.

Digges, Dudley, 109

Diggs, William, has 72 slaves, 158 .

Dinwiddie county. noor whites in, 151; small slave lolders of, 153; large slave holders in, 158.

Dodman, John, landownet, 79.

Dorch. Walter, inventory of, 106.

Duties.

French put on English wonlens, 1.i; nn reëxported tobaceo partly refunded. 70 : on reexported tobacco, 117; on tobacco yicld grown large revenue, 120 .
Enwards, John, slaves of in plot, 128.

Edwards, William, has six tithables, 57 ; slaves of in plot, 128.

Effingham, Lord, tyranny of in Virginia, 114

Elizabeth City, plantations of small, 53; farms and tithables of, 58 ; servants and slaves in, 59.

Emigration

from Virginia in years from 1660 to $1725,40,62,139-1+6$; not caused by large land grants, 144.145; extent of, 146.

England,

colonial expansion necessary for, 7 ; forests depleted, 7 ; industry declining, 8 ; Baltic trade of, 8 ; future depends on colonies, 13 ; 14; joy of at founding of Virginia, 15; disappointed in Virginia. 19; tobaceo bill of, 26; supplies Virginia with labor, 31; poverty in, 31; eannot consume entire colonial tobacco crop. 86; tobacco planting in prohibited. 87; glut of tobacco in. 68.89 ; aflheres to colonial policy, 95 .

Epes, Francis

Essex, $9,127$.

land transfers in. 46; plantations of small, 53; farms and tithables of, 558 .

$\mathrm{F}$

ILING Creck,

iron works at, 17; destroyed in 16\%, 18.

Fane, Francis, Fish, says slave labor cheapens tohaceo, 132 plentiful in Virginia, 15.

Fithian, Philip, describes poor whites of Virginia, 152. 155.

Fitzhugh, William,

Flax, 109 ; refers to slave imports, 130.

in Virginia, 15.

Fleet, tohacco.

brings servants, 35 ; size of in 1690 and 1706,122

Foster, Armstrong,

$79,80$.

Foster, Robert, huys 200 acres, 50 .

Fowl, wild,

abundant in colonial Virginia, 102

Fox, William. has 25 slaves, 153 .

France.

exports wine and silk, 1'; Rrilish trade with declines, 13 ; trbacen trarle to. 119 trate to injured by war, 131.

Freedmen

80 per cent of servants hecome. 4n. prior to 1660 remained in Virginia, 40 ; 
form large part of population, 41 ; an. nual recruits of 41 ; usually young. 42 ; might acquire property, 43 ; perform bulk of work, 43 ; what became of 43 ; become snall planters, 60 ; outfit of, 61; not entitled to land, 61; prosperity of linges on tobacco, 62; Virginia land of opportunity for, 71 ; profits of from to. bacco, 71.72; in Burgesses, 73.74; pros. perous, $74-80$; little hope of advance. ment for after $1660,97-100 ; \mathrm{few}$ in rent roll of $1704,122.123$.

Frecmen,

entitled to headrights, 35; many come to Virginia, 36; hecome small planters, 60-75; many pay own passage, 81.82.

Ficight rates.

high from England, 71.72; cxcessive, 90 .

Fruit,

Fuel,

12, abundant in Virginia, 102.

| G ARDENS, $_{\text {, }}$

abundant in Virginia, 105.

common in Virginia, 102, 105.

Garnet, John,

buys 600 acres, 50.

Gicorge, The.

takes cargo of tobacco to England, 25: 64 .

Githert. Gienrge, patents land in James City, 77, 79.

Gilbert, Sir lllumplirey, voyage to Amcrica, 11.

Glass, fossibilitics for in Virginia. 15; hegin. ning made of in Virginia, 17; early his. tory of in Virginia, 18.19.

Gloucester,

averagc plantation in, 54 ; farms and tithables of, $58 ; 80 ; 113$; poor whites of, 151; mall slave holders in, 15t; large slave holders in, $157 ; 159$.

Guod, John, describes poverty in Virginia, 91.

Gooch, Governor, says large hollings no impediment to settlement, 145 ; says poor whites make best tobacco, $1+7$.

\section{Governor.}

plants tobacco, 28; appoints sheriffs, 51 ; makes efforts to collect quit rents, 51 ; 65: neglcets servants, $73 ; 90 ; 109$; clect ci by lurgesses, $1652 \cdot 1660,112$.

Goring, John, cervants and slaves of, 59 .

Cirain, abundance of in Virginia, 102.

Graves, Ralpl, his servant valued at $£ 10,127$.

Grey, lames, buys 200 acres, 49.

Giry. lolun. bis catlle, 101; inventory of, 100 .

Grey. Francis. Burgess and landonner, 78.79 .
Grey, Thomas, 78

$\mathrm{H}$ AKLUYT, Richard advises colonial expansion, 11 ; shows British dependence on Spain, 12; ex pects surplus of population in England to emigrate to Amcrica, $16 ; 19$

fHammond, John, advice to servants, 61 ; describes Virginia residences, 104.

Harmar, Charles, imports slaves, 124.

Jarris, John. Burgess in 1629,73

Harrison, Benjamin 109.

Hart, Ienry, his slave in plot, 128 .

llartwell, Henry, deals in servants, 48

Jatrey, Sir John, complains of low prices for tohacco, 65 askis freedom of tralle for Virkinia, 68 testifies to illegal foreign trade, 6869 complains of high freight rates, 72 . ejected by people, 110 .

IIatfield. James, landowning ircedman, 75 .

IIeadrights,

described, 34; 35; averaged about 1750 a year, 41; determine size of land grants, 47; brought in by well known planters, 48: do not belong to servant, 61; appear in wills, 76: transfer of hy sale. 76; become landowners, 77 ; not all servants, 77; comparel with rent roll 97.99

Hemp.

in Virginia, 15.

Henrico,

false returns in, 55; farms and titlubies of, 58 ; servants and slaves in, $59 ; 79$.

Hill, Edward, 109.

Hill, John, landowning frecdman, 75; book binder at Oxford, 75

Hodge, Jchn, servants and slaves of, 59 .

Holding, John, landowner, 79.

Holland,

exports fish, 12; trate of declines, 13 ; controls slave trarle, $31 ; 125 ;$ tobacco exports to, 86.89; Nariflation Acts cut cxports to, 87; distributor of Englislı colonial tolacco. 88; plants own tobacco, 88; wars With, 89; Virginians threaten to revolt to. 91, 96; 116; tobaeco exports to, 120; fights to preserve her monopoly of slite traile, 126; secks to control tobaceo trade on contincnt, 149 . 150.

linney,

podnced in Virginia, 102. 
Hotten's Emigrants to America. gives lists of servants, $42 ; 73$.

Houses, comfortable in Virginia, 103.10t.

Howlett, William, buy 200 acres, 50.

$I_{M}$

IGRATION.

volume of in 17 th century, 35.36; fixes character of eastern Virginia, 36; not restricted to servants, 36 .

Indentures, system of. 32 ; terms of, 61 .

Indjans. desire to convert, 14 ; revere tobacco, 24; unsuited for laborers, 30 .

Industry

22; pictured in Virginia, 28; Virginia not suited for, 29 .

Inventories.

throw light on distribution of servants and slaves. $59 ; 73$; typical examples of. 106-107.

Iron,

smelting of exhausts forests, 8 ; criuld be smelted in Virginia, 15; early manufacture of in Virginia, 17-1s.

Isle of Wight county,

farms and tithables of, 58; 79.

$\mathrm{J}$

Acksox, William,

has 49 slaves, 158 .

Tames I.

forced to use tobacco, 25; considers smoking harmful, 26; regulates tolbace? trade, $6 \%$

James II. tyranny of, 114.

James City county.

plantations and tithables of, 58; lant. owners listed as headrights in. $76-77$; 79 ; slave plot in, 128.

James River. iron works on, $17 ; 39 ; 70 ; 148$.

Jamestown,

14; glass furnace at. 18; streets of planted with tobacco, 25;86;111;112.

Jefferson, Thomas, says slavery made whites lazy, 155.

Teffreys, Ieffrey. imports slaves. 131.

Jennings, Edmund.

109; describes slave plot, 128.129; says slaves injure credit of Virginia, 130; says few servants in 1708. 130-131; describes slave trade, 130.131; describes migration of poor whites, 145-146.

Johnson, John.

sells land, 49.

Johnson, Joseph, transports servants, 78.79 .

Iones, Anthony, servant, becomes landowner, 74.

Jones, Hugin, says tenants small part of population, 45; 155; says negroes make poor arti. sans, 156 .
Jorlan, Lt. Col. pays taxes on seven tillables, 56 .

$K_{\text {EMP, Richard, }}$ says immigrants mostly servants, \&2.

King William county. farms and tithables of, 58 .

King and Queen county, farms and tithables of, 58 .

Kinsman, Richard, makes perry', 108 .

Knight, Sir John, says Virginia ready to revolt to Holland. 96.

T, в B

lack of in Virginia, 16; foreign at Jamestown, 18; lack of handicans indus try, 19; 20; in Virginia determined by tobacco, 23; cheap needed in Virginia. 29; serious problem, 29; Indians un suited for, 30 ; slave, 30 ; England supplies, 31; indenture system to supply. 32; influx of, 35

L.ancaster.

79; poor planters in, 151; small siave holders of, 153 .

Land.

cheap in Virginia, $29 ; 45$; transfers of in Surry county, 46; in York, 46; in Rappahannock, 46; listed in rent roll of $1704-5,53$; monopoly of said to cause migration from Virginia, 141-143; large tracts gratued, $1+2.1+4$.

1.and grants.

average extent of. 47; determiner by method of transporting immigrants, $4^{-}$ vary greatly in size. 47; not index ti size of plantations, 49

Lanlowners,

few large in 17 th century. $43 ;$ glad to sell in small parcels, 45; chiefly small proprietors, 46; in census of 1626,46 ; in York county, 46; in Essex, 46; often avoid quit rents, 51 ; listed in rent roll of 1704-5. 53; small proprietors neglected in history, 54; often poor men. 55; many work farms with own hands. 57; Goternment expects servants to be. come, 62; profits of from tobacco, 71-72.

Larkin, George, describes large land holdings, $14 t$

Liwrence, Richard, landowner, 79

Leah and Rachel. 61.

Lee, Richard imports 80 slaves, 125

Leightenhouse, Thomas. 127.

Linton, John, estimates colonial tobacco, 115; estimates amount of reexported tobacco, 118; declares Baltic tobacco trade ruined, 148; describes tobacco raising in Holland, 149 
lonton Company,

national character of, 13; plans manu. factures for Virginia, 15; cannot secure lalorers for Virginia, 16; sets up iron works at Falling Creek, 17-18; displeased at toloacco culture in Virginia, 25; tobacco only hope of, 26; expects Virginia to duplicate England, 28; high irice of tobacco pleases, $64 ; 73 ; 75$.

l.ulwell, l'hilip,

$109 ; 113$.

Ludwell, Thomas,

placcs average tobacco crop at 1200 pounds, $64 ; 90$; says tobacco worth nothing, $90 ; 91 ; 96$.

\section{Minifactures,}

attempts to establish in Virginia, 15-19; cause of failure, 19 ; purchased from Dutch, 68-69; colonial system based on expectation of, 86; Berkeley tries to establisl, 95; local in Virginia, 103; of tobacco in England, 119, 122; exports of to tohaceo colonies, 120 ; in northern colonies lure Virginia whites. $140 ; 141$; on plantations, $108 ; 156-157$.

Market,

not free for tobacco, 66; tobacco sent to foreign, 67-70; Navigation Acts cut of foreign, 87; tohacco reexported to con. tinental, 116.120; Virginia and Maryland furnish for England, 120.

Naryland

emigration of whites from, 140; House of Delcgates of explains migration, 191.

Mlason, Francis, seven tithables. 57.

Mason, Winfield,

has 40 slaves, 158 .

Massacre, iron works destroycd during, 18.

Matthews, Samuel. his estate described, 108.

Nerchant marine. thrcatcned in England by lack of ship. building materials, 9; part of sea defense, 10; depleted at end of $16 \mathrm{th}$ ccntury, 10; tobaceo exports aid British, 26. 119,122

It nefie, lieorge, his estate described, 108 .

Mirldlesex, plantations small, 53; farms and tithables of, 58 .

Nilner, Thomas, deals in servants, 48 .

Moseley, Capt. William, buys part of Button's Ridgc, 50, 109.

IItur, Francis, has 47 slaves, 158

Muscovy Company,

Baltic trade of, 8 ; not exempt from cus. toms, 9; urged to trade with Amcrica. 11.
$\mathrm{N}$ plantations of small, 53 ; plantations and tithables in, 58 .

Navigation Acts,

69; described, 84-86; resented in Holland, 88-89; Bland's remonstrance against, 88 ; cause of war with Holland, 89: cause extreme poverty in Virginia. 90-92; connected with Bacon's Rebcl. lion, 92.93; why Virginia Assembly did not protest against, $94-95 ;$ Berkele protests against, $94.95 ; 98$; retard growth of poptuation, 98.99 ; design of, 116.

Nori Albion,

describes abundance of food in Vir ginia, 103; advises settlers in Virginia as to clothing. 104.

Sew Description of Virginia.

presents optimistic picture of Virginia, 63 ; puts price of tobacco at $3 \mathrm{~d}$ a pound, 66; describes foreign tobacco trade, 69 . describes Virginia houses, 104; cites cases of wealth in Virginia, 107.

Now Kent, farms and tithables of, 58 .

Newport, Capt. Christopher, returns to England in 1607, 15; brings iron ore to England in $1607,17$.

New Jerscy manufactures of lure Virginia whites, 141 .

Nicholson, Sir Francis

29; 50 ; orders accurate rent roll in 1690 , 51; again attempts rent roll in 1699,52 ; completes rent roll, 52; 54; makes rent roll accurate, 55,$97 ; 114$; gives reason for migration from Vir ginia and Maryland, 140, 141; sues Col. Lawrence Smith for arrears of quit rents, 143 ; testifies to large land grants, 144.

Norfolk,

plantations of small, 53 ; farms and tith. ables of, 58 ; slave plot in, 129 .

Northampton,

farms and tithables of, $58 ; 79$.

North Carolina, servants flec to, 83.

Northern Neck, omitted in rent roll, $50 ; 54 ; 55$

Curton, Capt. Wm., brings glass workers to Virginia, 19; dies, 19.

$P_{\text {Age, Matthew, }}$ 109.

Page, Mann, has 157 slaves, 157.

l'agett. Anthony, Burgess in 1629,73

larke. Daniel, 109.

l'atent Rolls.

in Virginia Land Office, 34; average grants in, 47; show large dealers in 
servants, $48 ; 73$; reveal namcs of freedmen, $7+75$.

Pattison. Thomas, landowner. 79 .

Pearson, Christopher, inventory of, 107.

Pelton, George. 102.

Pennsyivania, manufactures of lure Virginia whites. 191; migration to, $139-146$.

Perfect Discription, numbers cattle in Virginia. 101.

Perry Nicajah, reports on tobacco trade. 119.

l'lantations.

Virginia made up of, 29; cheap in Vir ginia, 29; labor for, 29.37; unleaithful sites for, 39; fcw large, 43; small hold own with large, 44 ; small outnumber large, 45; 46; transfers of in Surry county, 46; patents not index to size of, 49 ; tendency to break up large into small, 49; listed in rent roll of 1704-5, 53. largest in various counties. 53; average size of, 53 ; accurately listed in rent roll, 55; comparison of number of with workers, 55; number in each county, 58; settlers buy on frontier. 76; part only of each cultivated. 105.

Popleton, William, Burgess in 1629, 73.

Population,

$28 ; 29$; growth of from 1649 to 1675 , 98 ; growtl of slow, 99,142

Potash,

England's need for, 8; found in Virginia, 15; first efforts to produce in Vir. ginia, 17 .

Pott. Dr. Iohn.

incites people against Sir John Harcey, 110.

Poultry

plentiful in Virginia, 102.

Poverty.

in England, 31; Navigation Acts cause in Virginia, 91; one cause of Bacon's Rebellion, 92.93.

Present State of Tobacco Plantations.

describes tobacco trade to France and Spain, 119; puts tobacco duties at $£+00,000,121$; describes ill effects of wars on tobacco trade, 148.

Prince George county, plantations and tithables of, 58 .

Princess Anne county, plantations of small, 53; 54; farms and tithables of, 58; slave plot in, 129; small slave holders in, 154 .

Public Record Office,

has copy of rent roll of 1704,52 .

Quary, Colonel,

says wars ruin tobacco trade, $148 ; 157$.

Quit rents,

collected by Crown on land, 50; revenue from considerable, $50 ; 51$; often in arrears, 51 ; roll of in 1704, 51-55.
Ramshaw, William, landowning freedman, 75

Randall, Robert, seven tithables, 57.

Randolph, Edward, remarks on slow growth of Virginia population, 99; says holdings of large tracts of land causes migration from Virginia, 141-143; says quit rents avoid ed, 142; suggests limiting size of grants. 143.

Randolph, William, imports slaves. 130 .

Rappahannock county,

land transfers in, 46; landowners of listed as headrights, $76 ; 79$.

Rent Roll.

Nickolson orders, 51; attempted in 1699 , 52; completed in $1704-5,52$; shows small plantations, 53 ; accuracy of, $54-55$; 5,500 farms listed in, 55 ; compared with tithables of 1702, 57.58; compared with headrights, 97.99 ; contains names of few freedmen, 122-123.

Restoration Period,

brings suffering to Virginia. 84; 97; $104 ; 115 ; 116$.

Rich, Nathaniel,

buys tobacco at 2 s a pound, 64.

Ruberts, Robert.

buys land, 49.

Robertson, William, makes copy of rent roll of 1704,52 .

Robins, Sampson, 79; patents land, 80.

Roluinson, John, lanlowning freedman, 75 .

Rolfe, Capt. John, first to cure Virginia tobacco, 24; 25.

Rooking, William, servants and slaves of, 59.

Rowlston, Lionell, servant, Burgess in 1629,$73 ;$ Burgess in 1632,74 ; landowner. 74 .

Russell, John,

landowning freedman, 75 .

Russia,

tobacco trade to, $118-119 ; 148$.

Samuel, Anthony,

buys 300 acres, 50

Sandys, George,

selects site for iron works, 17; describes failure of glass works in Virginia, 19, writes for servants, 30 ; gives wages of laborers, 44

Sandys, Eir Edwin, expects Virginia to duplicate England, 28

Savadge, Thomas,

landowning freedman, 74 .

Scotchmon, Robert,

servant, Burgess in $1632,74$.

Scott, Thomas, lias 57 slaves, 158 .

Seruely, Richard, patents land, 79. 
Servants,

London Company sends to Virginia, 16; Indian children as, 30; system of inlenturcs for, 32; not criminals, 32; politica! prisoners among, 33; Irish among, 33; Oliacrian soldiers among. 33; they plot against Goacrnment, 33; Scotchmen among, 33; Sedgcmour pris oners among, 33; chiefly Englishmen, 34,36 ; list of preserved, 34 ; headrights from, 35; influx of, 35; four or five years of service for, 38 ; become part of Virginia social fahric, 39; hardship and perils encountered ly, $39 ; 80$ per cent. become freedmen, 40; prior to $1660 \mathrm{re}$ mained in Virginia, 40; length of ser vice for, to; usually young when freed, 11, 42; cstimated at 6,000 in 1671,41 ; "seasoned," 42; become small part of population, 43 ; merchants bring to comilete cargoes, 47 ; individual orders for, 48 ; in immigrant ships, 48 ; dealers in, 48; numbers in 1704,56 ; listed as tith. ables, 56; distribution of, 58.59; not slaves, 60; like English apprentices, 60; outfit of on expiration of term, 61; not entitled to land. 61; hope to become landlowners, 61.62; Virginia land of opportunity for, 71 ; freedmen of ten purchase, 72 ; of early period become prosperous, 73.80 ; list of, 78 ; proportion of among immigrants, 81-82; little hope for advancement of after 1660, 96-100. importation of in Restoration period, 98.99; inventories which show none, 106-107; many freed to fight in Bacon's Rebcllion, 113; few become landowners at end of $17 \mathrm{th}$ century, 112.113 ; useful. ness of as compared with slaves, 126; price of, 127 ; not always docile, 128 slave labor curtails importation of, 134 ; England opposes migration of, 135; vast numbers imported, 142.

Seymour, Attorney-General, tells Virginians to make tobaccn, 136.

Sheep, scarce in Virginia, 102.

Sheriff. collects quit rents, 51; draws up rent roll, 52; uncarths false returns, 54.55.

Sherwood, William, calls Bacon's men rabble, 93.

Shiplunilding.

materials for needed in England, 8; lack of injures merchant marine, 9 ; ma terials for found in Virginia, 15; Capt. Smith explains why Virginia cannot pro. duce materials for, 17.

Shurley, Daniel, landowning freclman, $7 \mathrm{H}$.

Sickness, The Virginia, Capt. Blewit dies of, 18; glass workers die of, 19; servants die of, 33; described, 39 ; terrible mortality from, 39, 80 ; abates before cnd of 17 th centry, 40: 1ut fatal to slaves. 128.
Silk, from South Europe, 12; in Virginia, 15. Slaughter, John, 80

Slave trade,

in hands of Dutch, 31; restrictions on, 45

Slaves.

adequate for tobacco raising, 29; first cargo of in Virginia, 30; few in Vir. ginia prior to 1680,31 ; influx of, 40 ; numbers in 1704,56 ; listed as tithables, 56; distribution of, 58.59 ; inventories show that many planters liad none, 106107; used by wealthy men in 17 th century, 108; first cargo of, 124; few prior to 1680, 124; importations of, $124 \cdot 125$; Dutch control trade in, 125-126; fitness of for tobacco culture, 126; price of, 127 ; labor of crude, 127-128; health of good, 128 ; docile, 128; plots among, 128-129; 110 wrong seen in, 129; duty on importa. tion of 129; large importations of, 1680 . $1708, \quad 130-131 ; 6,000$ by 1700,130 ; 12,000 in 1708,$130 ; 30,000$ in 1730,131 ; usc of cheapens tobacco, 132; use of curtails importation of servants, 134; England favors use of in Virginia, 135. 136; pernicious effect of in ancient Rome, 137-139; effect of on Virginia yeomanry, 139-155; causes migration of whites, 139.146; at first produce only lower grades of tobacco, 147; become more efficient, 147 ; contempt of for poor whites, 152; small holders of, 152-159; east stigma on labor, 155; large holders of increase in numbers, 155-159.

Sinclting,

wood needed for, 8; in Virginia, 15; machinery for sent to Virginia, 17; be. gun at Falling Creck.

Sinith, Capt. John, describes Baltic trade, 8; explains diff. culty of building up manufacturers in Virginia, 17.

Smither, William, buys 200 acres, 50.

Simyth,

describes poor whites of Virginia, 152, 155 .

Splin,

commerce with, 12; growing domains of, 14; tol,acco of used in England, 25, 26; tobacco of excluded from England, 67, $68,86,87$; tobacco trade to, 119 ; trade to injured by war, 131 .

Spanish Succession, War of, $103 ; 115 ; 119$; cuts off tobacco trade to France and Spain, 131; 148.

Sparshott, Edward, landowning freedman, 74.

Simith, Lawrence, sued for arrears of quit rents, 143.

Spartes, John,

landowning freedman, 74 .

Sipencer, Capt. Robt., servants and slaves of, 59. 
Spencer, Secretary, writes of reviving tobacco trade, 115; says slaves cheaper labor than whites, 132 .

Splitimher, John, his cattle, 10]; inventory of, 106.107.

Spotsylvania,

large grants in, 145; poor whites in, 151; small slave holders of, 153-154; land transfers in, 154; large slave holders in, $157 ; 159$.

Spotswood, Alexander, says slaves cause over production of tobacco, $129 ; 151$; has 60 slaves, 158 .

Storey, John, imports negroes, 130 .

Stuarts, second despotisn of affects Virginia, 114.

Stublefield, George, has 42 slaves, 158 .

Surry, land transfers in, 46; tithables in, 56. 58 ; inventories and wills in, 59 ; negroes plot in, 128 .

Sweden, tobacco trade to, 118-119.

Symonds, Roger, granted 100 acres, 81 .

$\mathrm{T}$ Aliaferro, Richard, has 43 slaves, 158 .

Tenants, few in Virginia, 47, 45, 62.

Thoroughgood, Adam, servant, Burgess in 1629,$73 ;$ Burgess in 1632, 74; landowner, 75 ; brother of Sir John Thorouhgoood, 75 .

Tithables,

those listcrl as, 56; in Surry, 56-57; number of in various comnties, 58 .

Tobacco, history of Virginia built on, 20, 23; Indians revere, 24; first cured in Virginia by Rolfe, 24; Virginia suited for 24; ready market for, 24; extensively used in England, 24; used by James I, 25; Virginians turn eagerly to culture of, 25; send first cargo of to England, 25; London Company displeased at cul ture of, 25; England reconciled to, 26; Virginia's only hope, 26; Crown tries to divert Virginia from, 27 ; cultivation in Virginia universal, 27 ; shapes immigra. tion, 29; requires unskilled labor, 29 ; prosperity of freedmen hinges on, 62; amount of one man could produce, 63 64 ; over production of in 1640,63 ; price of prior to $1660,64-67$; account for migration of 1618-1623, 64; rich re turns from, 64; restrictions on trade of, 67-69; growing of in England pro. hibited, 67; $\operatorname{tax}$ on, 67; illegal foreign trade in, 68-69; reëxported from Eng land, 70; Virginia underbids world in, 70 ; returns from, 71-72; freight on high, 72 ; effect of Navigation Acts on, 85-96; foreign trade in prohibited, 85 ; requires world market, 86; planting in England prohibited, 87; exports of to Spain, 87; reexported, 87; planted in Holland, 88; glut in England causes price of to drop, 89.91; exliausts soil, 105; Charles I makes offer for, 110; trade of revives. 115-116; production of incrcases, 115 116 ; returns from, 116; reexports of. 116.120; production of abroad, 117 duty on yields crown large revenue, 121 ; price of still low at end of $17 \mathrm{tl}$ century, 123 ; slaves adequate to it cultivation, 127-128; wars interfere with trade in, 131 ; slaves cheapen pro duction of. 132 ; poor whites produce the best, 146-147; foreign trade in ruined by war, 148-150; advantages of large plan tations for, $156 \cdot 157$.

Towns,

few in Virginia, 29.

Townsend, Richard,

Burgess in 1629, 73 .

Trussell, John.

landowning freedman, 74

Turnhull, Rohert, has 81 slaves, 158 .

Underwood, John, patents land in James City, 77 .

lipton, Tohn. landowning freedman, 75.

$V_{\text {egetables, }}$

abundant in Virginia, 10 ?

Tirginia's Cure says Burgesses mostly freedmen, 74 rirginia Unmasked, describes Virginia houses, 104

I'irginia . Magazine of History and Biography', shows that many freedmen migrated to Virginia, 81.

I'irginia Richly Valued, advises emigrants as to outfit, 104 .

$W_{\text {AGEs, }}$

high in Virginia, $16 ; 29 ; 30 ;$ low in England, 31

IVage earners.

few in Virginia, 44; mostly recently frced servants, 44 .

IValker, Robert,

has 52 slaves, 158 .

Warburton, Thomas, patents land in James City, 77

Varden. Thomas, landowner, 79

Warwick, average plantation of, 53; farms and tithables of, $58 ; 81$.

IVashington, Richard, deals in servants, 48.

Watson, John, landowning freedman, 75 .

Weaver, Samuel, landowning freedman, 75 . 
II ebster, Roger, servant, Burgess in 1632. 74.

Whitlock. Thomas. will of $105 \cdot 106$.

IVilliamsburg, $35 ; 54$.

Williams. William, buys 200 acres, 50 .

IIills,

throw light on distribution of servants and slaves, $59 ; 73$; headrights mentioned in, 76.

Wine, prospect for in Virginia, 15.

Noolens. need of potash for, 8; French duty on. 13.

Moolritel, William, landowning freedman, 74 .

Wormsley, Ralph.

109; letter to from Fitshugh, 130.

Wry, Thomas, granted 50 acres, 81.

$Y_{\text {ates, William, }}$ hias 55 slaves, 158 .

Veomanry, largest class in Virginia, 59.62; freedmen in, 72-82; 85; desperately poor, 90.91 ; driven to revolt by poverty,

9).93; no advancement for after 1660 , 97.100 ; enjoy plentiful food, 101.103; often suffer for proper clothing, 103 105; Burgesses represented interests of, 109 ; aid in ejecting Harvey, 110; many favor Parliament in Cizil War, 110.111; in control from 1652 to 1660,112 ; chief sufferers from Narigation Acts, 113; support Bacon in rebellion, 113; struggle for political rights, 114; few recruits to at end of 17 th century, 122 ; condition of at end of 17 th century, 123; effect of slavery on in ancient Rome, 137-139; migration of from Virginia, 139-146; produce higher grades of tobacco, 146 . 147 ; misery of in 1713,150 ; many sink into poverty, 151-154; many become slave holders, 152.159; slaves make less industrious, $155 ; 160$.

Veardley, Sir George,

29 ; instructed to enforce free exchange rork, of goods, 65 .

land transfers in, 46; plantations of small, 53; farms and tithables of, 58 ; servants and slaves in, 59: landowners of who had been headrights, 76; 79; $107 ; 130$.

Young, Richard. granted 100 acres, 81 




$12+$ 


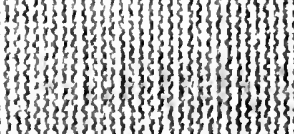

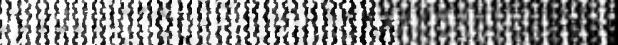

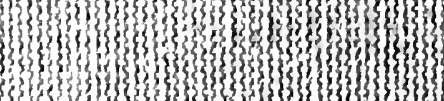

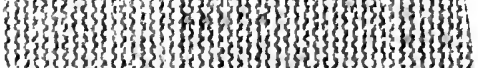

IIS

3.

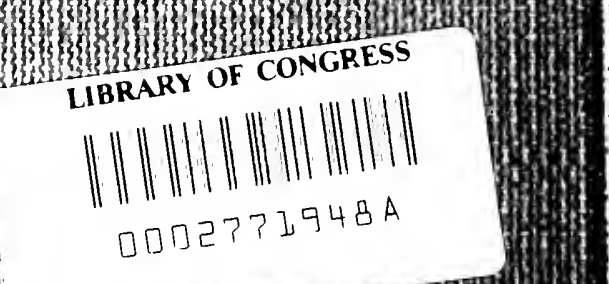

1.

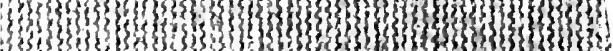

$14 y_{3}$, 3.

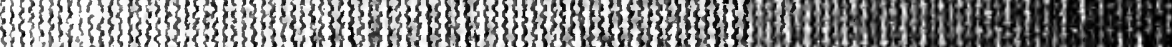
\{ny S. y my M. 3.

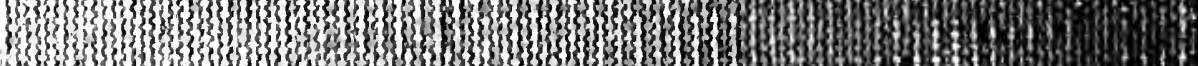
U\}乡

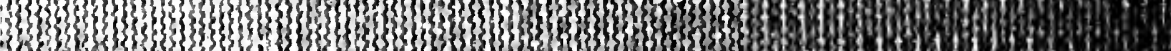

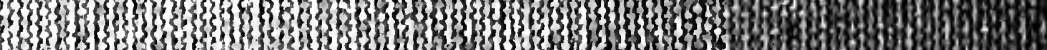

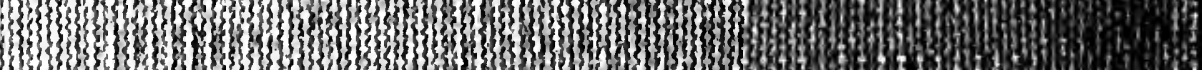
인

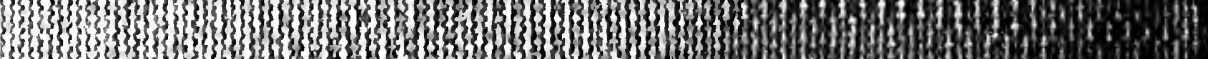

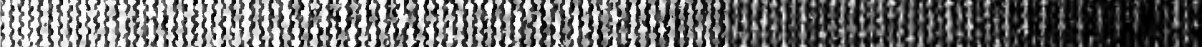
3. in

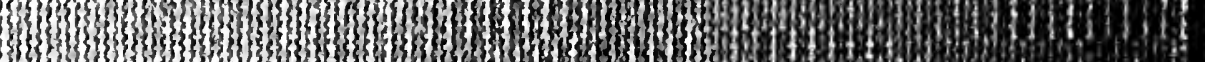
s.

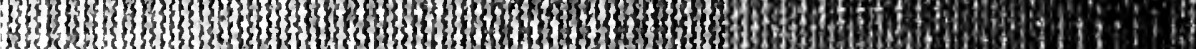
y 约结

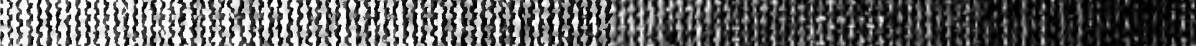
${ }^{3} 3$ 3.

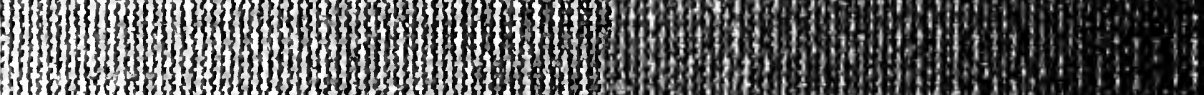
is 